\title{
CONSUMO DE FRUTAS: UM ESTUDO EXPLORATÓRIO
}

\section{Gabriela Fazio de Carvalho}

Engenheira Agrônoma

Orientador: Prof. Dr. RUBENS DA COSTA SANTOS

Dissertação apresentada à Escola Superior de Agricultura "Luiz de Queiroz", Universidade de São Paulo, para obtenção do título de Mestre em Ciências, Área de Concentração: Economia Aplicada.

\section{PIRACICABA}

Estado de São Paulo - Brasil

Janeiro - 1998 
Dados Internacionais de Catalogação na Publicação (CIP) DIVISÃO DE BIBLIOTECA E DOCUMENTAÇÃO - Campus "Luiz de Queiroz"/USP

\section{Carvalho, Gabriela Fazio de}

Consumo de frutas: um estudo exploratório / Gabriela Fazio de Carvalho. - . Piracicaba, 1998.

229 p.

Dissertação (mestrado) - - Escola Superior de Agricultura Luiz de Queiroz, 1998. Bibliografia.

1. Consumo alimentar 2. Fruta 3. Uso domiciliar I. Título 


\section{CONSUMO DE FRUTAS: UM ESTUDO EXPLORATÓRIO}

GABRIELA FAZIO DE CARVALHO

Aprovada em: 01.04.1998

Comissão julgadora:

Prof. Dr. Rubens da Costa Santos

ESALQ/USP

Prof. Dr. João Gomes Martines Filho ESALQ/USP

Dr. Flávio Condé de Carvalho

IEA/SP

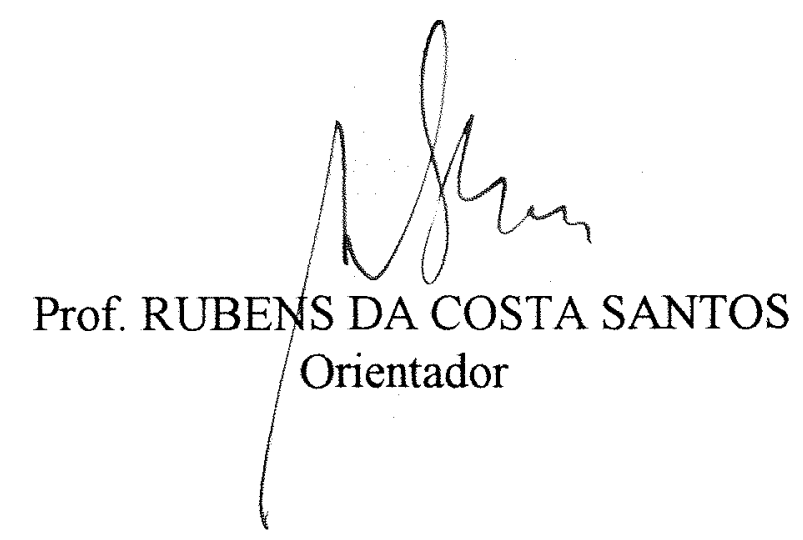




\section{AGRADECIMENTOS}

Ao Professor Rubens da Costa Santos, pela orientação precisa, apoio e incentivo constantes durante a elaboração deste trabalho.

Ao Departamento de Economia e Sociologia Rural da Escola Superior de Agricultura "Luiz de Queiroz", pela possibilidade de realização deste Curso de Mestrado.

Aos Professores João Gomes Martines Filho, Pedro Valentim Marques e Ana Lúcia Kassouf pelo auxílio e valiosas sugestões para o aperfeiçoamento deste trabalho.

Ao Professor Flávio Condé de Carvalho, pelas valiosas sugestões que muito contribuíram para o aperfeiçoamento deste trabalho.

Aos demais professores do Departamento de Economia e Sociologia Rural pelos valiosos ensinamentos compartilhados durante o Curso de Mestrado.

Aos funcionários do Departamento de Economia e Sociologia Rural, pelo auxílio e amizade desenvolvida durante o Curso de Mestrado.

Aos colegas de curso, pela amizade e apoio durante a realização do Curso de Mestrado.

Ao $\mathrm{CNPq}$, pela concessão de bolsa de estudos para realização deste curso.

À minha familia, pelo constante incentivo e apoio às minhas realizações.

Ao meu marido Marcelo, presença constante, pelo apoio, compreensão e amizade nos momentos mais dificeis. 


\section{SUMÁRIO}

Página

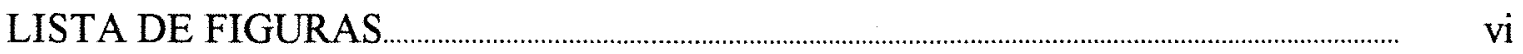

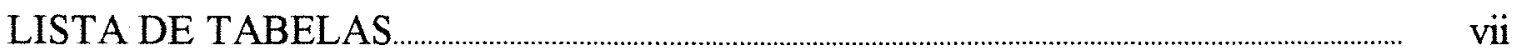

RESUMO

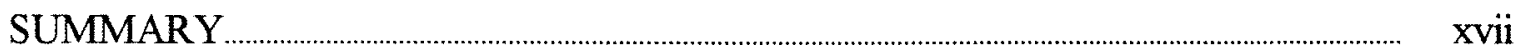

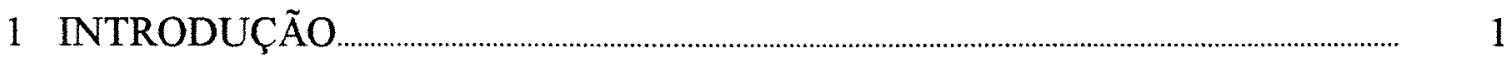

2 CONTEXTUALIZAÇÃO DO TEMA _......................................................... 12

2.1 Processo de tomada de decisão de compra do consumidor ….................. 12

2.1.1 Modelo de tomada de decisão pelo consumidor ...................................................... 13

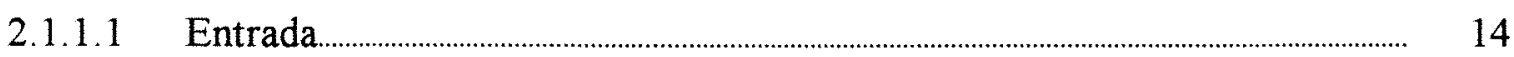

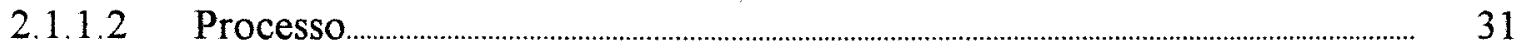

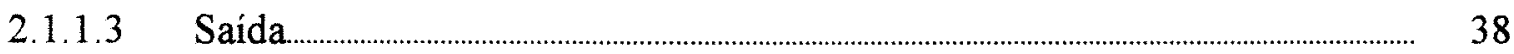

2.1.2 Modelo de decisão de compra familiar ................................................................. 39

2.1.3 Estágios do processo de tomada de decisão de compra do consumidor ...... 44

2.1.4 Modelo simplificado do processo de compra ...................................................... 45

2.1.5 Sumário e contribuições .................................................................................. 47

2.2 Comportamento de consumo de frutas .................................................................... 48

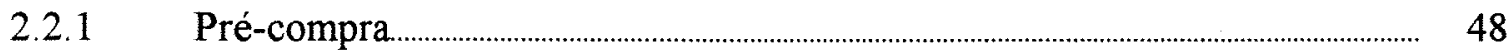

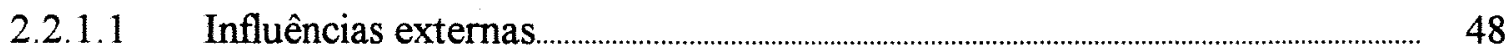

2.2.1.1.1 Atividades de marketing _................................................................ 49

2.2.1.1.2 Ambiente sociocultural …............................................................................. 52 
2.2.1.2 Influências internas .............................................................................................. 59

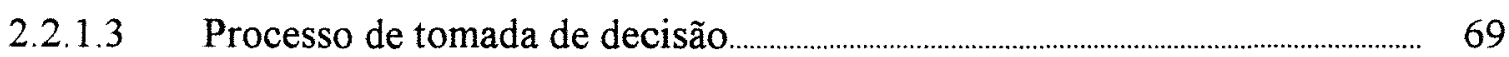

2.2.1.3.1 Reconhecimento do problema ...................................................................................... 69

2.2.1.3.2 Busca de informação ................................................................ 70

2.2.1.3.3 Avaliação das alternativas............................................................................. 71

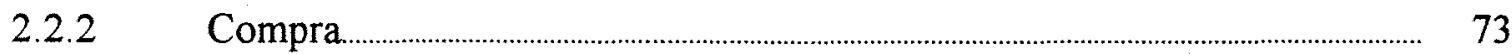

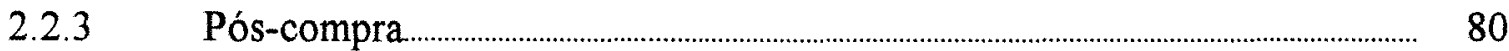

2.2.4 Sumário e contribuições .............................................................................................. 82

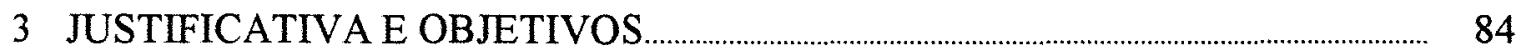

4 METODOLOGIA

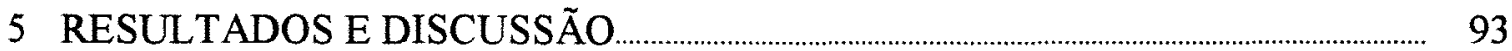

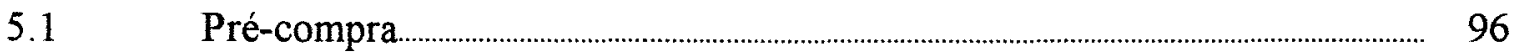

5.2 Compra

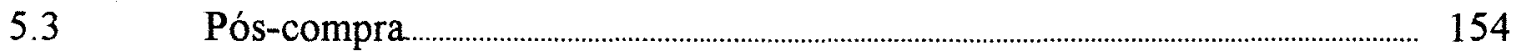

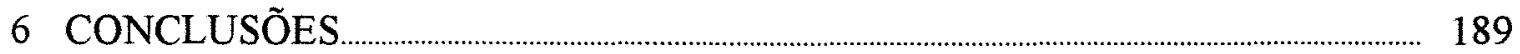

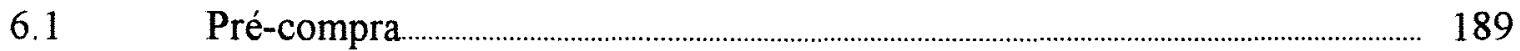

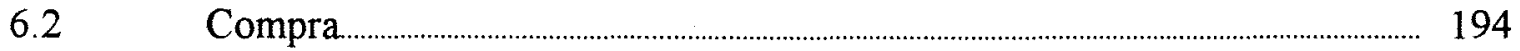

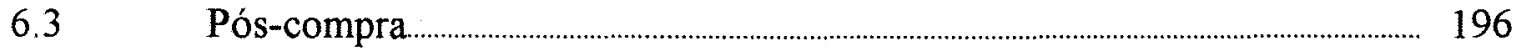

6.4 Modelo

7 SUMÁRIO, LIMTTAÇÕES E PESQUISAS FUTURAS …...................................... 200

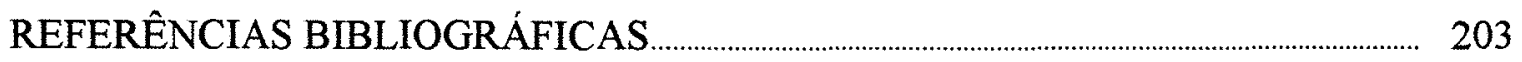

Apêndice 1: FORMULÁRIO PARA ENTREVISTAS _............................................ 211

Apêndice 2: RECURSOS VISUAIS (CARTÕES) UTILIZADOS NAS

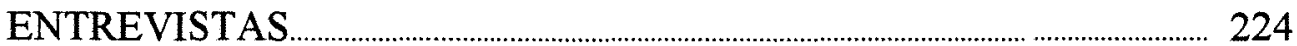




\section{LISTA DE FIGURAS}

Página

1 Distribuição percentual dos gastos com furtas

2 Consumo anual per capita na Região Metropolitana de São Paulo por grupo de produtos.

8

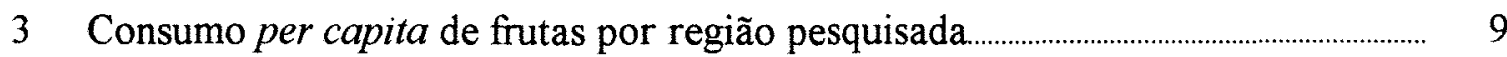

4 Modelo simplificado de tomada de decisão do consumidor ……………................................ 14

5 Segmentação por beneficios pessoa-situação ………………………….......................................... 27

6 Conjunto evocado como um subconjunto do conjunto de todas as marcas em uma categoria de produto .......................................................................................... 34

7 Modelo de decisão de compra familiar ......................................................................................... 40

8 Estágios do processo de decisão de compra do consumidor ................................................. 44

9 Modelo simplificado do processo de compra................................................................................ 46

$10 \mathrm{O}$ que o consumidor mais valoriza em produto alimentar industrializado? (espontâneo) - em porcentagem do total da amostra

11 Atributos, por ordem de importância, nas decisões de compra de alimentos (quanto maior o valor, maior a importância do atributo).

12 Participação de cada fruta no gasto total - Famílias com recebimentos de 1 a 40 pisos salariais - Região Metropolitana de São Paulo 76

13 Preferência $(\%)$ - Tipo de fruta $\mathrm{x}$ situação de consumo 


\section{LISTA DE TABELAS}

Página

1 Consumo per capita anual (em $\mathrm{kg}$ ) - Região Metropolitana de São Paulo - ENDEF, 1974/75.

2 Consumo per capita anual (em kg) - Região Metropolitana de

São Paulo - POF, 1987/88

3 Freqüência do consumo de frutas por nível de renda, em porcentagem.

4 Freqüência no consumo de frutas por cidade, em porcentagem. 11

5 Características das situações de consumo

6 Efeitos interacionistas influenciando o processamento de informação e tomada de decisão do consumidor

7 Definições para os componentes psicológicos do modelo de Shiffman \& Kanuk.

8 Tipos de risco percebido pelo consumidor em situação de tomada de decisão.

9 Tipos de regras de decisão não compensatórias...

10 Fatores que determinam decisão conjunta.

11 Causas das mudanças ambientais e suas conseqüências no mercado de alimentos.

12 Distribuição percentual das pessoas de 10 anos ou mais de idade, segundo as classes de rendimento mensal, 1981/89Brasil. 
13 Distribuição percentual das pessoas de 10 anos ou mais de idade, segundo as classes de rendimento mensal, 1979/88 Estado de São Paulo

14 Proporção de famílias por número de pessoas ocupadas (exclusive pensionistas, empregados domésticos e parentes dos empregados domésticos), 1981/90 - Brasil..

15 Número médio de pessoas por família, 1981/ 90 - Brasil

16 Distribuição das famílias por número de componentes (em porcentagem), 1981/ 90 - Brasil

17 Exemplos de atributos que implicam em qualidade real e em pseudo qualidade

18 Consumidores de produtos organicamente produzidos, na Dinamarca, em porcentagem.

19 Tipos de fontes de informação nutricional por categoria

20 Critérios principais na aquisição de frutas e verduras e frequiências mencionadas, em porcentagem

21 Local de compras por porcentagem de consumidores que os utilizam.

22 Diferenças na percepção de características de frutas frescas supridas por supermercados e lojas especializadas (porcentagem de indivíduos que julgam cada característica aplicável para supermercados ou lojas especializadas)

23 Tipo de embalagem das frutas adquiridas pelos consumidores, dezembro - 1995, em porcentagem

24 Motivo de escolha de frutas a granel apresentado pelos consumidores, dezembro - 1995, em porcentagem.

25 Motivo de escolha de frutas embaladas apresentado pelos consumidores, dezembro - 1995, em porcentagem. 
26 Motivo de escolha de frutas a granel e embaladas apresentado pelos consumidores, dezembro - 1995, em porcentagem.

27 Tipo de atividade promocinal observado pelos consumidores em relação ao item frutas, dezembro - 1995, em porcentagem

28 Motivo do consumo de frutas apresentado pelos consumidores, dezembro - 1995, em porcentagem

29 Resposta dos consumidores em relação às preocupações com a saúde estimulando ou não o consumo de frutas, dezembro - 1995, em porcentagem

30 Motivo da influência das preocupações com a saúde no consumo de frutas apresentado pelos consumidores, dezembro - 1995, em porcentagem

31 Preocupação dos consumidores com resíduos químicos nas frutas frescas adquiridas, dezembro - 1995, em porcentagem..

32 Resposta dos consumidores em relação ao consumo de produtos orgânicos, dezembro - 1995, em porcentagem

33 Motivo do não consumo de produtos orgânicos apresentado pelos consumidores, dezembro - 1995, em porcentagem

34 Motivo do consumo de produtos orgânicos apresentado pelos consumidores, dezembro - 1995, em porcentagem.

35 Tipos de frutas preferidas pelos consumidores (pontuação com ponderação*), 10 primeiros na classificação geral, dezembro 1995

36 Tipos de frutas compradas pelos consumidores (pontuação com ponderação*), 10 primeiros na classificação geral, dezembro 1995

37 Rejeição a um ou mais tipos de frutas apresentada pelos consumidores, dezembro - 1995, em porcentagem. 
38 Tipos de frutas rejeitadas apresentados pelos consumidores - 10 primeiros na classificação geral, dezembro - 1995, em porcentagem.

39 Forma de consumo das frutas apresentada pelos consumidores (pontuação com ponderação*), dezembro - 1995.

40 Frutas consideradas adequadas pelos consumidores para consumo in natura - 10 primeiras na classificação, dezembro-1995, em porcentagem

41 Resposta dos consumidores em relação ao uso de frutas como ingrediente, dezembro - 1995 , em porcentagem

42 Frutas consideradas adequadas pelos consumidores para consumo como ingrediente - 10 primeiras na classificação, dezembro - 1995, em porcentagem.

43 Resposta dos consumidores em relação ao uso de frutas para preparar sucos, dezembro - 1995, em porcentagem.

44 Frutas consideradas adequadas pelos consumidores para consumo na forma de suco - 10 primeiras na classificação, dezembro - 1995, em porcentagem

45 Ocorrência de interferência do uso das frutas no processo de escolha das mesmas, conforme ressaltado pelos consumidores, dezembro 1995, em porcentagem

46 Confiabilidade das fontes de informação sobre frutas apresentada pelos consumidores - pontuação com ponderação*, dezembro - 1995

47 Importância dos atributos de uma fruta apresentada pelos consumidores - pontuação com ponderação*, dezembro - 1995. 
48 Tipo de informação desejada pelos consumidores no ponto de venda sobre as frutas que consomem, dezembro - 1995, em porcentagem.

49 Fatores considerados importantes pelos consumidores em relação ao ambiente do ponto de venda (pontuação com ponderação*), dezembro $-1995$.

50 Ocorrência de interferência do tempo disponivel no processo de escolha de frutas, conforme ressaltado pelos consumidores, dezembro - 1995, em porcentagem

51 Consequêencias da limitação temporal sobre 0 processo de escolha/compra de frutas apresentadas pelos consumidores, dezembro - 1995, em porcentagem

52 Resposta dos consumidores em relação à compra de frutas da estação, dezembro - 1995, em porcentagem

53 Motivo apresentado pelos consumidores para aquisição de frutas da estação, dezembro - 1995, em porcentagem

54 Locais de compra de frutas apresentados pelos consumidores (pontuação com ponderação*), dezembro - 1995.

55 Motivo de escolha do local de compra de frutas apresentado pelos consumidores, dezembro - 1995, em porcentagem

56 Ator no processo de tomada de decisão de compra de frutas, dezembro - 1995, em porcentagem

57 Ator no processo de compra de frutas, dezembro - 1995, em porcentagem

58 Tipo de armazenamento de frutas nas unidades domiciliares apresentado pelos consumidores, dezembro - 1995, em porcentagem.

59 Freqüência de preparo das frutas para o consumo apresentada pelos consumidores, dezembro - 1995, em porcentagem 
60 Influência da situação de consumo no tipo de fruta a ser escolhido apresentada pelos consumidores, dezembro - 1995, em porcentagem.

61 Resposta em relação ao consumo de frutas no café da manhã apresentada pelos consumidores, dezembro - 1995, em porcentagem

62 Frutas preferidas no café da manhã apresentadas pelos consumidores, dezembro - 1995, em porcentagem.

63 Resposta em relação ao consumo de frutas como um lanche durante a manhã apresentada pelos consumidores, dezembro - 1995, em porcentagem

64 Frutas preferidas em um lanche durante a manhã apresentadas pelos consumidores - 10 primeiras na classificação geral, dezembro - 1995, em porcentagem.

65 Resposta em relação ao consumo de frutas como sobremesa do almoço apresentada pelos consumidores, dezembro - 1995, em porcentagem.

66 Frutas preferidas como sobremesa do almoço apresentadas pelos consumidores - 10 primeiras na classificação geral, dezembro - 1995, em porcentagem

67 Resposta em relação ao consumo de frutas como um lanche durante a tarde apresentada pelos consumidores, dezembro - 1995, em porcentagem.

68 Frutas preferidas em um lanche durante a tarde apresentadas pelos consumidores - 10 primeiras na classificação geral, dezembro - 1995, em porcentagem.

69 Resposta em relação ao consumo de frutas como sobremesa do jantar apresentada pelos consumidores, dezembro - 1995, em porcentagem 
70 Frutas preferidas como sobremesa do jantar apresentadas pelos consumidores - 10 primeiras na classificação geral, dezembro-1995, em porcentagem

71 Resposta em relação ao consumo de frutas como um lanche após o jantar/antes de dormir apresentada pelos consumidores, dezembro - 1995, em porcentagem

72 Frutas preferidas em um lanche após o jantar/antes de dormir apresentadas pelos consumidores - 10 primeiras na classificação geral, dezembro - 1995 , em porcentagem.

73 Grau de satisfação em relação às frutas compradas apresentado pelos consumidores, dezembro - 1995, em porcentagem.

74 Motivo apresentado pelos consumidores que se afirmaram pouco satisfeitos com as frutas adquiridas, dezembro - 1995 , em porcentagem.

75 Motivo apresentado pelos consumidores que se afirmaram moderadamente satisfeitos com as frutas adquiridas, dezembro - 1995, em porcentagem

76 Motivo apresentado pelos consumidores que se afirmaram bastante satisfeitos com as frutas adquiridas, dezembro - 1995, em porcentagem

77 Motivo apresentado pelos consumidores que se afirmaram totalmente satisfeitos com as frutas adquiridas, dezembro - 1995, em porcentagem.

78 Grau de desperdício de frutas na unidade domiciliar apresentado pelos consumidores, dezembro - 1995, em porcentagem.

79 Motivo apresentado pelos consumidores para nenhum desperdício de frutas na unidade domiciliar, dezembro - 1995, em porcentagem.

80 Motivo apresentado pelos consumidores para pouco desperdício de frutas na unidade domiciliar, dezembro - 1995, em porcentagem.

81 Motivo apresentado pelos consumidores para moderado desperdício de frutas na unidade domiciliar, dezembro - 1995, em porcentagem.

82 Destino dos resíduos de frutas apresentado pelos consumidores, dezembro 1995 , em porcentagem. 


\title{
CONSUMO DE FRUTAS: UM ESTUDO EXPLORATÓRIO
}

\author{
Autora: GABRIELA FAZIO DE CARVALHO \\ Orientador: Prof. Dr. RUBENS DA COSTA SANTOS
}

\section{RESUMO}

O presente estudo está centrado no processo de tomada de decisão de consumo, em relação a frutas in natura, com foco no consumo domiciliar.

Em um primeiro momento, foi feita uma revisão bibliográfica sobre o processo de consumo, com a apresentação de alguns modelos de comportamento considerados relevantes para o estudo em questão. Além disso, também foi realizada uma pesquisa bibliográfica sobre características específicas do consumo de frutas, tanto a nível nacional, como internacional.

A partir deste referencial teórico foi proposto um modelo simplificado, adaptado ao consumo específico de frutas. Este modelo foi utilizado como base para o estudo, visando a obtenção de uma caracterização mais adequada de cada fase do processo de consumo deste tipo de produto. A estrutura proposta pelo modelo simplificado se divide em três fases, pré-compra, compra e pós-compra.

Com estes subsídios, realizou-se uma pesquisa exploratória de campo, com o objetivo de testar a estrutura proposta pelo modelo simplificado, verificando se o mesmo 
permite uma caracterização adequada de processo de consumo desse tipo de produto. A pesquisa de campo foi realizada no Município de Piracicaba, em cem unidades residenciais, através de entrevistas estruturadas.

Embora o objetivo central do estudo não fosse caracterizar cada fase do comportamento de consumo de frutas, mas sim testar a adequação do modelo simplificado proposto, o estudo apresentou alguns dados que merecem destaque.

A influência sociocultural pareceu interferir no comportamento de consumo. Este resultado foi percebido devido à estratificação dos resultados por fatores como renda, escolaridade etc.

Durante a pesquisa de campo, percebeu-se que o consumo de frutas foi influenciado por preocupações com a saúde. A preocupação com a ingestão de resíduos químicos, decorrente do consumo de frutas, também foi ressaltada pela maioria dos consumidores entrevistados.

Em relação aos diversos tipos de frutas, os resultados da pesquisa mostraram haver estreita correlação entre as frutas preferidas e as efetivamente compradas. Os principais tipos de frutas destacados pelos consumidores como efetivamente comprados foram: laranja, banana e maçã.

Em relação ao ponto de venda, os entrevistados ressaltaram a importância da limpeza. O principal local de compra de frutas foram os sacolões/varejões. Em segundo lugar, os consumidores ressaltaram os supermercados.

Em relação ao grau de satisfação dos consumidores com as frutas, a maioria dos entrevistados afirmou estar bastante ou totalmente satisfeita com os produtos adquiridos. 
Finalmente, em relação ao descarte, a maioria dos consumidores afirmou que não ocorre nenhum desperdício na unidade domiciliar. Os resíduos, por sua vez, são jogados no lixo, conforme destacado pela maioria dos entrevistados.

Finalmente, pode-se concluir que a utilização, no levantamento de campo, da estrutura proposta pelo modelo simplificado apresentado, permitiu uma caracterização adequada de cada fase do processo de consumo de frutas. Estes resultados vieram a comprovar a adequação desta estrutura para análise do consumo específico desse tipo de produto. 


\title{
FRUIT CONSUMPTION: AN EXPLORATORY STUDY
}

\author{
Author: GABRIELA FAZIO DE CARVALHO \\ Adviser: Prof. Dr. RUBENS DA COSTA SANTOS
}

\section{SUMMARY}

The core of this study is the consumer behavior for fresh fruit in the household.

At first, a research for literature regarding the decision-making process was made. The information from this research presented some models of consumer behavior, which were very important in order to interpret the results of this study. A local and international research in the literature was also carried out to obtain more detailed information about fruit consumption.

Using this information as a support, a model of consumer behavior adapted to fruits was developed. This model was used as a basis for this study. The objective of this survey was to achieve an adequate description of the several parts that compose the decision-making process. The model provides a framework to evaluate the decisionmaking process, which is divided in three parts: prepurchase, purchase and postpurchase.

Using this framework as a support, a field research was made in order to test the efficiency of the framework, verifying if it permits an adequate characterization of each part of the decision-making process of fruit consumption. This exploratory research was 
conducted in the city of Piracicaba, São Paulo State, Brazil. The interviews were given in one hundred households, using a questionnaire as a data collection instrument.

The main purpose of this study was to test the proposed framework and not to characterize each part of the decision-making process of fruit consumption. Even so, the field research presented some data that deserves attention.

The sociocultural influence seems to change the consumer behavior. This effect was noted based on data stratification by items such as income, education etc.

The field research data indicated that consumer behavior was also affected by health concerns. Regarding chemical residues, the majority of respondents reported to be concerned with the presence of these substances in fruits.

Regarding fruit varieties, the data from field research indicated that there is a correlation between the preferred fruits and the purchased ones. The most purchased fruits were: orange, banana and apple.

Regarding the place of purchase, the respondents indicated the importance of cleanliness. The main retail points were "sacolões/varejões" (type of supermarket, which sells fruits and vegetables). Secondly, the respondents showed the supermarkets as an important source for buying fruits.

Regarding consumer satisfaction with fruits, the majority of respondents reported to be satisfactorily or totally satisfied with the purchased products.

The majority of respondents reported that there is no waste in the household and that leftovers of fruits (seeds, peels etc.) were discarded. 
According to the field research, the proposed framework gave an adequate characterization of each part of the decision-making process of fruit consumption. Therefore, this framework can be used to study the consumer behavior of fruits. 


\section{INTRODUÇÃO}

O setor agroindustrial, responsável pela produção de alimentos, é um setor de destaque na economia de muitos países. Para exemplificar sua importância basta mencionar que, em 1991, foi responsável por 17\% dos empregos e $16 \%$ do Produto Nacional Bruto (PNB) dos Estados Unidos da América (EUA), conforme mencionado por Manchester (1992). No caso brasileiro, embora não se possa fazer uma comparação direta com a situação americana, devido a diferente agrupamento no setor, os valores são bastante significativos. O agribusiness movimentou, em 1990, US\$ 140,3 bilhões, sendo responsável por $40 \%$ do Produto Interno Bruto (PIB), de acordo com Araújo et al. (1991).

Apesar da importância do setor, há uma carência de estudos sobre o mercado consumidor de alimentos. Os dados disponíveis sobre consumo, no Estudo Nacional da Despesa Familiar - ENDEF (1978) e na Pesquisa de Orçamentos Familiares - POF (1991), são antigos e agrupados sob diferentes metodologias, dificultando comparações.

Avaliando o mercado consumidor de alimentos, pode-se também perceber uma ausência de informações a respeito do consumo específico de frutas. Este fato pode vir a causar prejuízos a um desenvolvimento ainda maior do setor frutícola, o qual tem merecido destaque na produção agrícola brasileira, conforme pode ser observado através dos dados apresentados a seguir. 
O Brasil, caracterizado por diversas condições climáticas e distintos tipos de solos, apresenta uma produção agrícola bastante diversificada, que confere ao país o título de principal produtor mundial em vários setores. A fruticultura, apesar de representar apenas cerca de $5 \%$ das áreas cultivadas no país, assegura ao Brasil o primeiro lugar no ranking mundial dos países produtores de frutas in natura, de acordo com Carraro \& Cunha (1994).

No estado de São Paulo, de acordo com Fazio (1994), para se avaliar o volume de frutas produzido usam-se, em geral, dados de um mercado referencial, que é a Companhia de Entrepostos e Armazéns Gerais de São Paulo (CEAGESP), no qual foram movimentados cerca de 2,87 milhões de toneladas de produtos hortícolas em 1990. Neste período o item frutas representou $51 \%$ deste total, segundo informações da Secretaria de Agricultura e Abastecimento de São Paulo (1992). É importante ressaltar que $60 \%$ do volume total de frutas comercializado na CEAGESP é produzido no estado de São Paulo.

Apesar do volume produzido já ser significativo a fruticultura vem tendo incremento em sua produção, pois tem assegurado boa rentabilidade econômica ao produtor, mesmo em áreas relativamente pequenas. Conseqüentemente, muitos produtores vêem a fruticultura como opção às culturas de menor rentabilidade ou como alternativa para diversificação, de acordo com Fazio (1994).

Também é importante ressaltar a importância social da fruticultura em relação à geração de beneficios sociais. Segundo Brasil (1992), o setor de produção de frutas frescas é importante na geração de empregos, empregando grande contingente de mãode-obra ao longo de toda cadeia, desde a produção até a comercialização. Além disso, as frutas são oriundas, em grande parte, de pequenas e médias propriedades, com uso acentuado de mão-de-obra familiar, o que vem a favorecer a fixação do homem no meio rural. 
Pode-se concluir, portanto, que a fruticultura é um setor importante dentro da produção agrícola brasileira. No estado de São Paulo também nota-se um destaque do setor frutícola.

Um fator que deve ser mencionado, quando nos referimos à produção frutícola brasileira, está relacionado à exportação de frutas. De acordo com Carraro \& Cunha (1994), apesar do Brasil ser o principal produtor mundial de frutas, apenas $1 \%$ deste total se destina ao mercado externo, o que classifica o Brasil como $20^{\circ}$ colocado no ranking de exportadores de frutas in natura.

Embora a participação do Brasil no mercado mundial de frutas in natura ainda seja restrita, notam-se esforços para melhor situar o Brasil neste sentido. Já existem vários produtores se dedicando à produção de frutas para exportação. Pode-se citar como exemplo a produção de melão no Rio Grande do Norte e de diversas frutas no Vale do Rio São Francisco, onde estão sendo cultivados produtos de excelente qualidade.

O desenvolvimento do Brasil como um mercado exportador pode vir a aprimorar a qualidade das frutas, podendo inclusive repercutir na qualidade das frutas in natura consumidas no mercado interno, mesmo que, inicialmente, a melhor parcela da produção seja destinada ao mercado externo.

Em relação ao consumo de frutas, dados da CEAGESP, de acordo com Matsuda, diretor presidente da entidade, em entrevista à revista Cozinha Industrial (1990), mostram ainda que $70 \%$ do volume total de frutas negociado é consumido na capital e interior de São Paulo. Podendo-se perceber, a partir daí, a dimensão deste mercado consumidor, que é, inclusive, maior que o montante da CEAGESP, pois existem outros canais de comercialização de frutas, que não passam pela CEAGESP. 
Em relação às pesquisas oficiais sobre consumo de alimentos, há duas pesquisas importantes de serem citadas. Estas pesquisas são Estudo Nacional da Despesa Familiar ENDEF (1978) e Pesquisa de Orçamentos Familiares - POF (1991). Como cita-se várias vezes, neste estudo, dados destas pesquisas, será feita uma breve apresentação das mesmas.

O ENDEF (1978) foi iniciado em 18 de agosto de 1974, sendo que sua fase de campo durou um ano, terminando em 15 de agosto de 1975. A amostra incluiu, aproximadamente 55000 familias. Foi utilizado o chamado método de pesagem na pesquisa de alimentos, considerado o mais aconselhável para pesquisas deste gênero. Esta pesquisa foi feita a nível nacional, além disso, procurou-se fazer com que, na amostra, houvesse representatividade de cada região metropolitana, área urbana não metropolitana e área rural não metropolitana, para cada uma das regiões pesquisadas.

A POF (1991) foi realizada em 1987/88. Nesta pesquisa não foi contemplada a obtenção do consumo alimentar em quantidades fisicas de forma direta, sendo estabelecida uma estimativa a partir dos dados de despesa das familias com cada produto e a utilização de preços médios por quilograma ou litro. Foram pesquisadas, ao longo de 12 meses, 13611 domicilios, nas 11 áreas abrangidas pela POF. As áreas abrangidas pela POF foram: 9 regiões metropolitanas (Belém, Fortaleza, Recife, Salvador, Belo Horizonte, Rio de Janeiro, São Paulo, Curitiba e Porto Alegre), bem como Brasília e Goiânia.

A partir destas duas pesquisas serão apresentados dados sobre consumo de frutas, realizando, quando possível, comparações, mesmo que estas possam não ser totalmente confiáveis. Será também apresentada pesquisa da Feedback Serviços de Pesquisa (1991), mais atual, para tentar apresentar um panorama mais abrangente deste consumo 
O ENDEF (1978) apresenta dados de consumo per capita anual para diversas frutas (Tabela 1), para a região metropolitana de São Paulo. A POF (1991) apresenta dados do mesmo tipo, embora agrupando as frutas de maneira diferente, para a região metropolitana de São Paulo (Tabela 2).

As Tabelas 1 e 2 apresentam um indício de aumento do consumo de frutas (per capita/ ano), na região metropolitana de São Paulo. No entanto, não se pode concluir, através da observação destas tabelas, que o consumo realmente aumentou, devido às diferenças metodológicas entre as pesquisas.

Tabela 1: Consumo per capita anual (em kg) - Região Metropolitana de São Paulo ENDEF, 1974/75.

\begin{tabular}{lc}
\hline \multicolumn{1}{c}{ Item } & Quantidade $(\mathrm{kg})$ \\
\hline Laranja & 21,0 \\
Banana & 9,2 \\
Tangerina & 5,3 \\
Outras frutas tipo europeu & 2,9 \\
Melancia e melão & 2,1 \\
Mamão & 2,0 \\
Maçã & 1,9 \\
Abacaxi & 1,8 \\
Limão & 1,5 \\
Abacate & 1,3 \\
Manga & 0,6 \\
Outras frutas tropicais & 0,4 \\
TOTAL FRUTAS & 50,0 \\
\hline
\end{tabular}

Fonte: Adaptado do ENDEF (1977) 
Em relação ao consumo de tipos específicos de frutas, embora as pesquisas tenham metodologias diferentes e haja alguns agrupamentos não coincidentes, pode-se estimar que as frutas mais consumidas, em ambas as pesquisas (Tabelas 1 e 2), para a região metropolitana de São Paulo, são laranja e banana. Em relação aos demais tipos de frutas, é dificil distinguir o que é demonstrativo de mudanças reais no padrão de consumo e o que pode ter sido influenciado por diferenças metodológicas entre as pesquisas.

Tabela 2: Consumo per capita anual (em kg) - Região Metropolitana de São Paulo POF, 1987/88.

\begin{tabular}{lc}
\hline \multicolumn{1}{c}{ Item } & Quantidade $(\mathrm{kg})$ \\
\hline Laranja & 23,5 \\
Banana & 10,3 \\
Mamão & 7,0 \\
Outras frutas tropicais & 4,2 \\
Outras frutas tipo europeu & 3,1 \\
Abacaxi & 2,7 \\
Melancia e melão & 2,7 \\
Maçã & 2,6 \\
Limão & 1,5 \\
Manga & 1,2 \\
Abacate & 0,9 \\
TOTAL FRUTAS & 59,7 \\
\hline
\end{tabular}

Fonte: Adaptado da POF (1991)

Em relação ao gasto com o item frutas, constatou-se, no último levantamento de consumo alimentar domiciliar per capita efetuado em 1987/1988 (POF, 1991), que $6,39 \%$ das despesas médias mensais familiares com alimentos diziam respeito às frutas. Deste total $14,2 \%$ correspondiam ao gasto com consumo de bananas, $23,4 \%$ com 
laranjas, 14,2\% com maçãs e 48,2\% com outras frutas (Figura 1). Através destes valores pode-se perceber a importância destes três tipos de frutas (banana, laranja e maçã) no consumo, pois somente estas frutas representam 51,8\% das despesas (com consumo de frutas).

Esses dados referem-se à média de consumo, pois este varia de acordo com o nível de renda das famílias. De maneira geral, quanto maior a renda, maior a porcentagem de gastos com frutas.

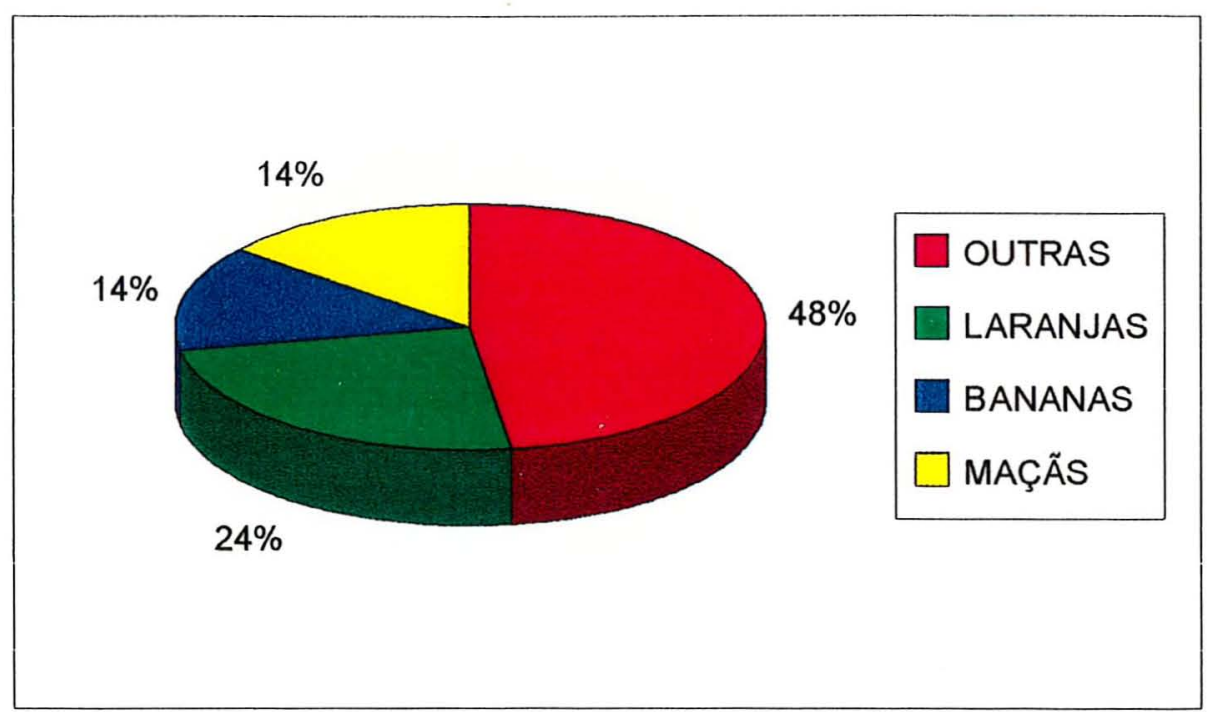

Figura 1: Distribuição percentual dos gastos com frutas.

Fonte: POF (1991)

Também é interessante analisar a quantidade consumida de frutas, na região metropolitana de São Paulo, em relação ao consumo de outros produtos alimentares (Figura 2). Percebe-se, observando-se esta figura, que o consumo de frutas, em quilogramas por ano (kg/ano), só perde para laticínios.

Comparando o consumo de frutas entre todas as regiões pesquisadas pelo Instituto Brasileiro de Geografia e Estatística - IBGE (Figura 3), pode-se notar o maior consumo desse produto, em kg/ano, na região metropolitana de São Paulo, onde se 
consome 59,67 kg/per capita/ano, sendo seguida pela região metropolitana de Salvador, com $51,31 \mathrm{~kg} /$ per capita/ano. A região que menos consumiu frutas foi Belém (região metropolitana), com apenas $27,43 \mathrm{~kg} /$ per capita/ano. Esta figura vem ressaltar a importância da região metropolitana de São Paulo como consumidora de frutas, no mercado nacional.

Em relação ao consumo de alimentos, a empresa Feedback Serviços de Pesquisa (1991) realizou, em 1991, pesquisa sobre hábitos de consumo, encomendada pela Revista Superinteressante (1991). A empresa consultou, para fazer a pesquisa, 1200 pessoas, dos sexos masculino e feminino, com idade entre 15 e 65 anos, com renda a partir de 2 salários mínimos, nas cidades de São Paulo, Rio de Janeiro, Belo Horizonte, Recife, Porto Alegre e Belém.

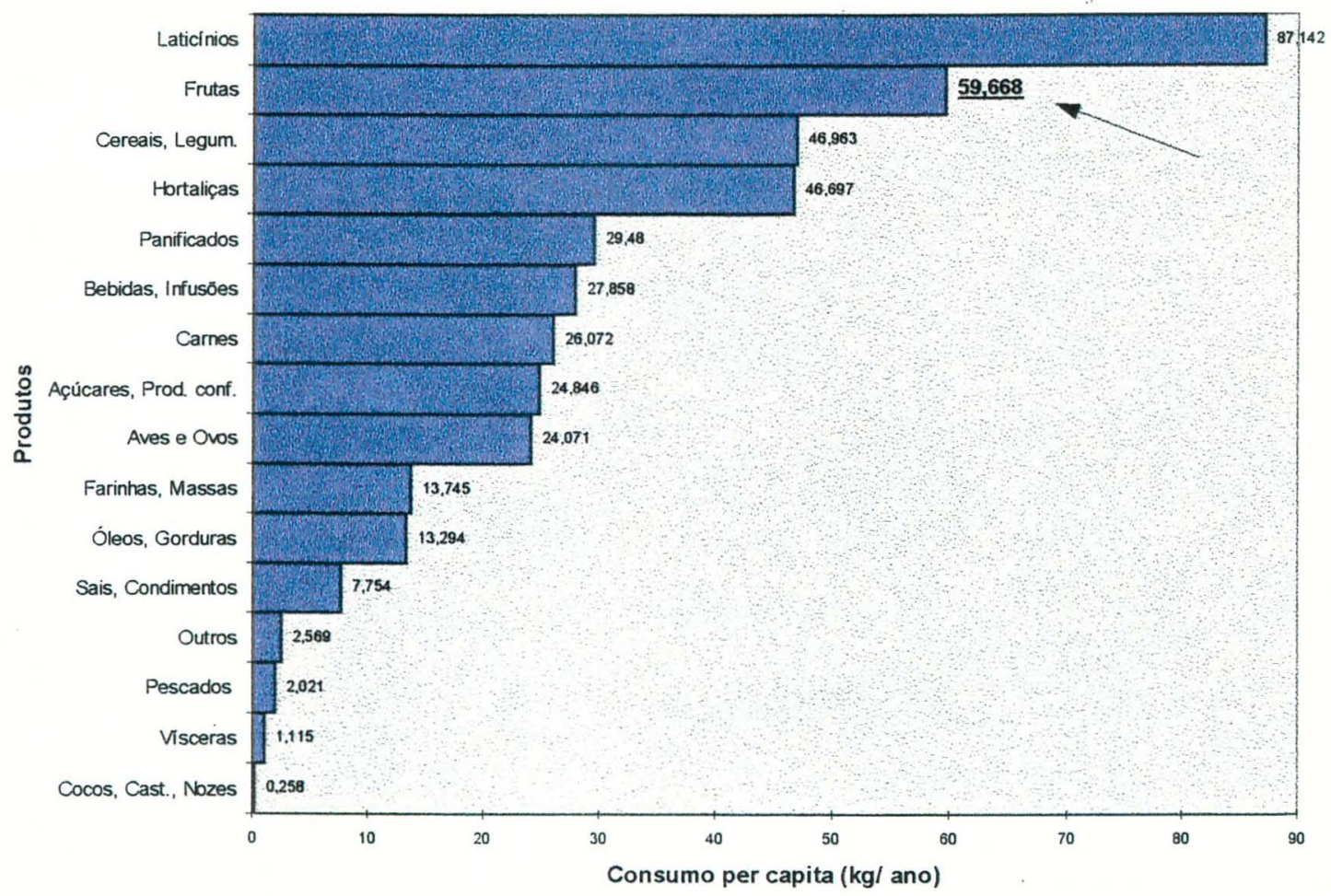

Figura 2: Consumo anual per capita na Região Metropolitana de São Paulo por grupo de produtos.

Fonte: POF (1991) 
Em relação ao consumo de frutas, a pesquisa apresenta dados interessantes a respeito da freqüência do mesmo. Estes dados podem ser observados nas Tabelas 3 e 4 .

A pesquisa da Feedback, conforme pode-se perceber na Tabela 3, confirma a tendência de aumento de consumo de frutas de acordo com nível de renda mais elevado, como podemos ver através do aumento do consumo diário de frutas, que passou de $43,5 \%$ da amostra, na classe de 2 a 5 salários mínimos, para $74,6 \%$ na classe que recebe mais de 20 salários mínimos.

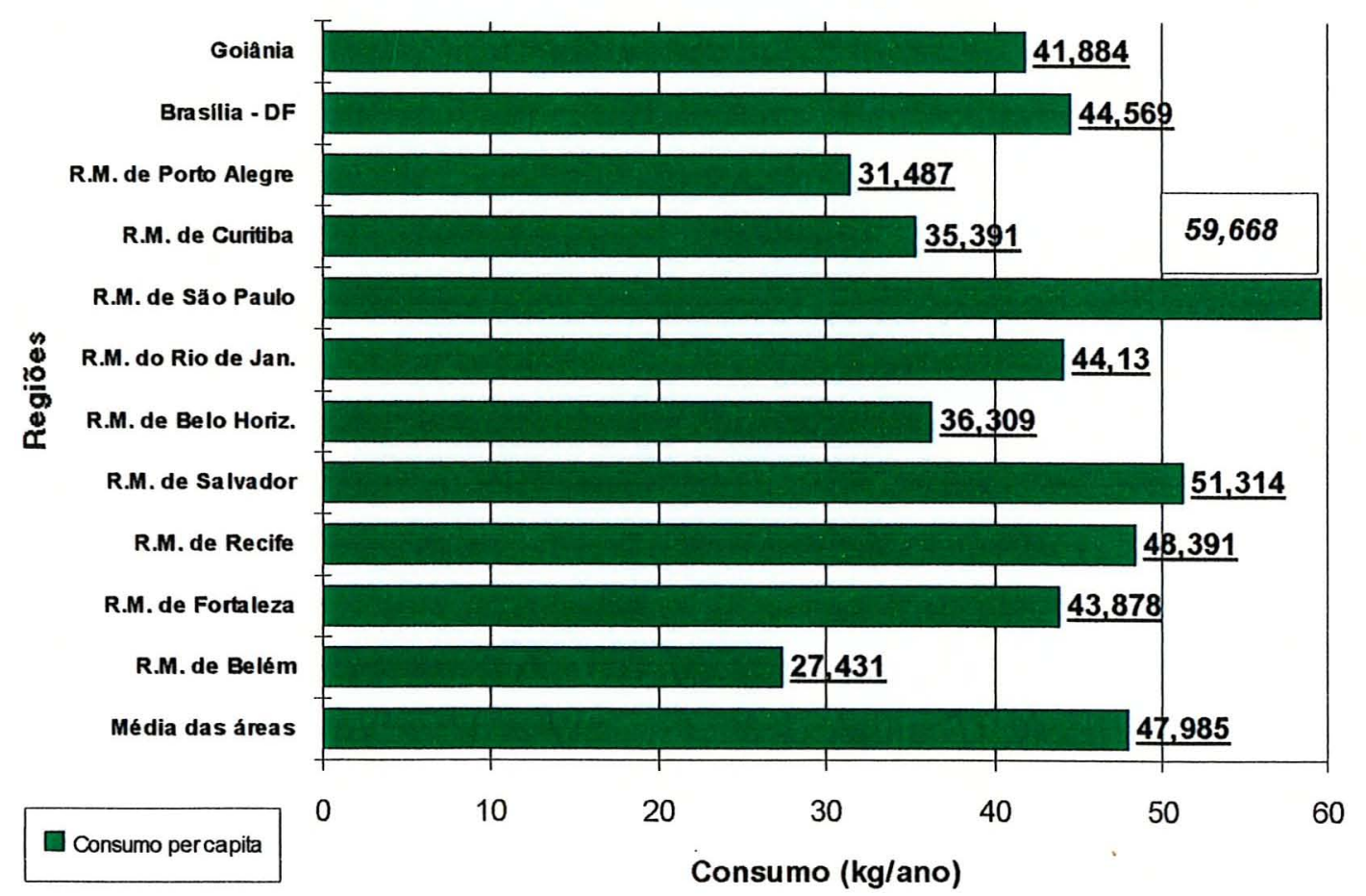

Figura 3: Consumo per cápita de frutas por região pesquisada.

Fonte: POF (1991)

A Tabela 4 confirma a importância da cidade de São Paulo, como grande consumidora de frutas, como podemos perceber pelas marcas percentuais atingidas, quando comparadas com as outras regiões. 
De maneira geral, estes dados não apresentam divergências muito significativas em relação aos apresentados pelo IBGE (POF, 1991), no entanto podem ocorrer distorções devido a metodologia de pesquisa diferente e ao intervalo de tempo entre as pesquisas.

Neste cenário, é importante ressaltar que um estudo que objetive esboçar melhor o mercado consumidor, através do estudo do processo de tomada de decisão de compra, para o setor frutícola, seria muito interessante, principalmente devido à ausência de estudos sobre o assunto.

Tabela 3: Freqüência do consumo de frutas por nível de renda, em porcentagem.

\begin{tabular}{lccccc}
\hline \multicolumn{1}{c}{ Frequência } & $\begin{array}{c}\text { 2 a 5 salários } \\
\text { mínimos }\end{array}$ & $\begin{array}{c}5 \text { a 10 salários } \\
\text { mínimos }\end{array}$ & $\begin{array}{c}10 \text { a 20 salários } \\
\text { minimos }\end{array}$ & $\begin{array}{c}\text { mais de 20 } \\
\text { salários mínimos }\end{array}$ & $\begin{array}{c}\text { amostra } \\
\text { total }\end{array}$ \\
\hline Todo dia & 43,5 & 56,8 & 59,2 & 74,6 & 55,3 \\
$\begin{array}{l}\text { 1 ou mais vezes } \\
\text { por semana }\end{array}$ & 42,8 & 29,2 & 29,6 & 18,4 & 32,5 \\
$\begin{array}{l}1 \text { a 3 vezes por } \\
\text { mês }\end{array}$ & 7,5 & 9,0 & 6,0 & 1,7 & 6,7 \\
Raramente & 5,0 & 4,8 & 4,9 & 3,8 & 4,7 \\
Nunca & 1,2 & 0,1 & 0,2 & 1,5 & 0,8 \\
Amostra & 36,2 & 28,6 & 19,2 & 16,0 & - \\
\hline
\end{tabular}

Fonte: Adaptado de Feedback Serviços de Pesquisa (1991)

Tendo em vista a importância do tema, o assunto abordado no decorrer dessa dissertação é o processo de tomada de decisão de consumo em relação a frutas in natura, com foco no consumo domiciliar. Assim sendo, quando houver menção do item frutas, neste trabalho, referir-se-á a qualquer tipo de fruta, adquirido na sua forma natural (in natura), ou seja, sem processamento. 
Para o desenvolvimento adequado do projeto, o mesmo foi dividido em seções $\mathrm{Na}$ primeira seção apresenta-se a contextualização do tema. Nesta seção será, primeiramente, apresentada uma revisão do comportamento de compra dos consumidores, com a apresentação de modelos, que serão utilizados como base para a elaboração de um modelo que se adeqüe ao consumo específico de frutas. Em um segundo momento, serão detalhados aspectos específicos do comportamento de consumo para o item frutas.

Tabela 4: Freqüência do consumo de frutas por cidade, em porcentagem.

\begin{tabular}{lcccccc}
\hline \multicolumn{1}{c}{ Freqüência } & São Paulo & $\begin{array}{c}\text { Rio de } \\
\text { Janeiro }\end{array}$ & $\begin{array}{c}\text { Belo } \\
\text { Horizonte }\end{array}$ & Recife & $\begin{array}{c}\text { Porto } \\
\text { Alegre }\end{array}$ & Belém \\
\hline Todo dia & 59,5 & 56,5 & 49,5 & 51,0 & 38,0 & 56,0 \\
$\begin{array}{l}1 \text { ou mais vezes } \\
\text { por semana }\end{array}$ & 28,5 & 33,5 & 35,5 & 31,0 & 47,5 & 33,5 \\
$\begin{array}{l}1 \text { a 3 vezes por } \\
\text { mês }\end{array}$ & 6,5 & 6,5 & 5,5 & 4,0 & 13,0 & 2,0 \\
Raramente & 5,0 & 3,0 & 7,0 & 12,5 & 0,5 & 8,0 \\
Nunca & 0,5 & 0,5 & 2,5 & 1,5 & 1,0 & 0,5 \\
Amostra & 44,3 & 29,9 & 8,4 & 6,4 & 8,5 & 2,5 \\
\hline
\end{tabular}

Fonte: Adaptado de Feedback Serviços de Pesquisa (1991)

$\mathrm{Na}$ segunda seção, são colocados os objetivos e a justificativa do trabalho. $\mathrm{Na}$ terceira parte será apresentada a metodologia de estudo a ser utilizada. Para completar, os resultados serão apresentados e discutidos. Finalmente, serão expostas as conclusões destes resultados, assim como sumário, limitações do trabalho e pesquisas futuras sugeridas a partir desse estudo. 


\section{CONTEXTUALIZAÇÃO DO TEMA}

Para uma contextualização adequada do assunto abordado no decorrer deste estudo será, primeiramente, apresentada uma revisão do comportamento de compra dos consumidores, com a apresentação de modelos, que serão utilizados como base para a elaboração de um modelo que se adeqüe ao consumo específico do item frutas. Em um segundo momento, serão detalhados aspectos específicos do comportamento de consumo para o item frutas, encontrados na revisão de literatura.

\subsection{Processo de tomada de decisão de compra pelos consumidores}

Para uma melhor compreensão do consumo de qualquer tipo de produto, é importante analisar o processo de tomada de decisão do consumidor.

Existem vários modelos que estudam a tomada de decisão pelo consumidor. Neste aspecto Schiffman \& Kanuk (1994) apresentam seis modelos de comportamento do consumidor. Os modelos são: modelo Nicosia ${ }^{1}$, modelo Howard \& Sheth ${ }^{2}$, modelo Engel-Kollat-Blackwell (Engel-Blakwell-Miniard³), modelo de tomada de decisão

\footnotetext{
${ }^{1}$ NICOSIA, F.M. Consumer Decision Processes. Prentice Hall, 1966.

${ }^{2}$ HOWARD, J.A. \& SHETH, J.N. The Theory of Buyer Behavior. Wiley, New York, 1969.

${ }^{3}$ ENGEL, J.F.; BLACKWELL, R.D.; MINIARD, P.W. Consumer behavior. $7^{a}$ edição, Dryden Press, 1993.
} 
familiar de Sheth ${ }^{4}$, modelo de processamento de informação de Bettman ${ }^{5}$ e modelo Sheth-Newman-Gross ${ }^{6}$, citados em Schiffman \& Kanuk (1994).

Os três primeiros modelos, ainda de acordo com Schiffman \& Kanuk (1994), estão centrados na tomada de decisão pelo consumidor, principalmente em como consumidores individuais chegam à decisão de marca. O quarto modelo trabalha com a tomada de decisão familiar. Neste modelo é dada uma atenção especial aos fatores que influenciam a extensão e natureza das contribuições dos membros familiares para a decisão de compra. O quinto modelo descreve uma visão do processamento de informação do consumidor. O sexto modelo está relacionado com valores de consumo, especialmente por que consumidores decidem comprar ou não determinado produto (usálo ou não), tipo de produto, marca específica.

Além destes modelos Schiffman \& Kanuk (1994) apresentam um modelo próprio de comportamento do consumidor, que visa sintetizar e coordenar conceitos relevantes. Devido a estas características do presente modelo, ele será usado como base para descrever o comportamento do consumidor, e, quando necessário, serão introduzidos aspectos dos outros modelos para complementar o estudo.

\subsubsection{Modelo de tomada de decisão pelo consumidor}

O modelo de Schiffman \& Kanuk (1994, p. 561), apresentado na Figura 4, tem três componentes principais: entrada, processo e saída.

\footnotetext{
${ }^{4}$ SHETH, J.N. Models of Buyer Behovior: Conceptual, Quantitative \& Empirical. Harper \& Row, New York, 1974.

${ }^{5}$ BETTMAN, J.R. An Information Processing Theory of Consumer Choice, Addison-Wesley, 1979. ${ }^{6}$ SHETH, J.N.; NEWMAN, B.I.; GROSS, B.L. Consumption Values and Market Choices: Theory and Applications. South-Western Publishing Co., 1991.
} 


\subsubsection{Entrada}

O componente entrada deste modelo, de acordo com Schiffman \& Kanuk (1994), consiste em influências externas que funcionam como fonte de informação sobre determinado produto, influenciando valores, atitudes e comportamento relacionados aos produtos de consumo. Os principais tipos de entradas apresentados pelos autores são as atividades de marketing das organizações, que visam comunicar os beneficios de seus produtos e serviços a consumidores potenciais, e as influências socioculturais, que afetam a decisão de compra do consumidor.

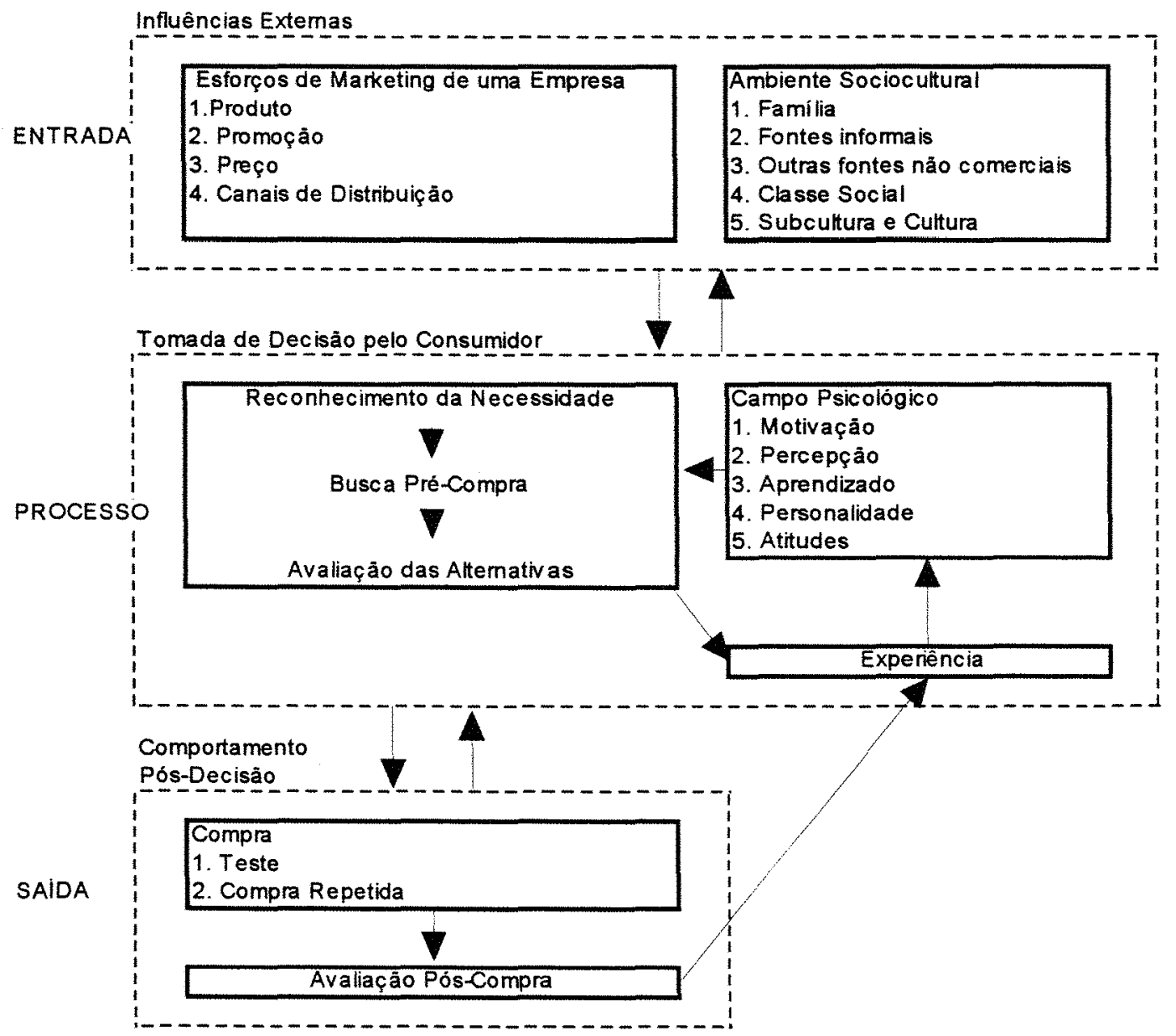

Figura 4: Modelo simplificado de tomada de decisão do consumidor.

Fonte: Schiffman \& Kanuk (1994, p. 561) 
As atividades de marketing de uma empresa, ainda de acordo com Schiffman \& Kanuk (1994), assumem a forma de estratégias específicas de composto de marketing (marketing-mix), consistindo em: próprio produto (embalagem, tamanho, garantias etc..); propaganda na mídia de massa, marketing direto, venda pessoal e outros esforços promocionais; política de preços; e seleção dos canais de distribuição, para movimentar o produto do fabricante para o consumidor final.

É importante ressaltar que o impacto dos esforços de marketing de uma empresa é governado pela percepção dos consumidores em relação a estes esforços, e não pelo impacto pretendido das mensagens de marketing.

O segundo tipo de entrada, o ambiente sociocultural, também exerce forte influência sobre o consumidor. Entradas socioculturais consistem em uma vasta gama de influências não comerciais, ainda de acordo com Schiffman \& Kanuk (1994). Os comentários de um amigo, um editorial de uma revista, ou uso por um membro da família são exemplos de fontes de informação não comerciais. Os autores ressaltam ainda que, embora sejam menos tangiveis, as influências exercidas pela classe social a que $o$ indivíduo pertence, cultura e subcultura, são fatores importantes que afetam o modo dos consumidores avaliarem e aceitarem (ou rejeitarem) produtos, consistindo também estímulos importantes.

Classes sociais, neste estudo, serão definidas como "divisão relativamente homogênea e permanentes de uma sociedade, organizada hierarquicamente, e cujos membros compartilham valores, interesses e comportamento similar", como apresentado por Kotler (1992, p. 210).

Ainda de acordo com Kotler (1992, p. 209), define-se cultura como "conjunto de valores básicos, percepções, preferências e comportamentos, que são aprendidos 
através de um processo de socialização envolvendo a família e outras instituições básicas".

Cada cultura seria, ainda, constituída de subculturas, que forneceriam uma identificação específica para seus membros. De acordo com este autor, pode-se distinguir quatro tipos de subculturas: grupos de nacionalidades, que se encontram em populações maiores e apresentam hábitos étnicos e inclinações distintas; grupos religiosos, que apresentam preferências culturais e tabus específicos; grupos raciais, como os negros e orientais, que têm estilos culturais e atitudes diferentes; e áreas geográficas, que podem constituir subculturas com estilos de vida característicos.

Schiffman \& Kanuk (1994) salientam que o impacto acumulativo dos esforços de marketing de cada firma, a influência da família, amigos e vizinhos, e o código de comportamento imposto pela sociedade constituem em entradas que, provavelmente, afetarão o que os consumidores comprarão e como usarão estes produtos. Como estas influências podem ser direcionadas para o indivíduo ou ativamente procuradas pelo indivíduo, duas setas (uma em cada direção) são usadas para ligar os componentes entrada e processo, no modelo apresentado na Figura 4.

Como complemento ao modelo de Schiffman \& Kanuk (1994), ainda dentro do ambiente sociocultural, pode-se incluir a influência situacional no comportamento de consumo, conforme apresentado por Engel et al. (1993). De acordo com estes autores, o comportamento é, na maioria das vezes, influenciado por fatores situacionais.

Antes de se discutir os fatores situacionais, precisa-se definir o termo situação. Neste estudo será adotada a definição de Belk (1974), ou seja, situação refere-se a fatores que são particulares a um período e lugar específicos, sendo independentes das características particulares dos consumidores e dos objetos. 
Ainda de acordo com Belk (1974), as características individuais incluem qualquer traço característico ou padrão de resposta que uma pessoa possa possuir, por um razoável período de tempo. Assim sendo, pode-se incluir, neste item, qualquer um dos fatores denominados por Thorndike ${ }^{7}$, citado em Belk (1974), como características gerais e duradouras dos indivíduos. Entre estes fatores tem-se: personalidade, habilidades gerais e intelecto. Estes fatores, conforme a definição de situação adotada, seriam considerados características dos indivíduos, não fazendo parte da situação.

As características do objeto de estímulo, segundo Belk (1974), em relação ao comportamento de compra, referem-se aos atributos de um produto ou marca particular, aos quais o consumidor deve responder. Estas características também não fazem parte da situação, de acordo com a definição adotada.

Os fatores situacionais, por sua vez, estariam definidos ao longo de cinco dimensões objetivas de situações, segundo visão de Belk ${ }^{8}$, citado em Engel et al. (1993). Estas dimensões seriam: arredores físicos, arredores sociais, tempo, tarefa e estados antecedentes, especificadas em maiores detalhes na Tabela 5 .

Após a definição de situação de consumo, seria também interessante observar a maneira através da qual se supõe ocorrer a influência da situação sobre o comportamento do consumidor, adotada neste trabalho.

Será, neste sentido, adotada uma posição interacionista, de acordo com posição de Bowers9 ${ }^{9}$ citado em Punj \& Stewart (1983). De acordo com este autor, os dois

\footnotetext{
${ }^{7}$ THORNDIKE, R. L. Research Problems and Techniques. Report $n^{\circ} 3$ AAF Aviation Psychology Program Research Reports. Washington: U.S. Government Print Office, 1974.

${ }^{8}$ BELK, R.W. Situational Variables and Consumer Behavior. Journal of Consumer Research 2. December, 1975, pp. 157-164.

${ }^{9}$ BOWERS, K.S. Situacionism in Psychology: An Analysis and a Critique. Psychological Review, 80, September, 1973. pp. 307-336.
} 
principais paradigmas de comportamento - teoria dos traços e situacionismo - tem se demonstrado inadequados para explicar o comportamento.

Tabela 5: Características das situações de consumo

1. Arredores fisicos: propriedades tangiveis contendo a situação do consumidor. Neste sentido tem-se: localização geográfica, decoração, som, aromas, iluminação, tempo, configuração das propagandas no ponto de venda e outros materiais ao redor do objeto de estudo.

2. Arredores sociais: presença ou ausência de outra pessoas na situação.

3. Tempo: propriedades temporais da situação, assim como o momento específico onde se dá o comportamento (horário, dia da semana, mês, estação). Tempo também pode ser medido em relação a um evento passado ou futuro (dias desde a última aquisição, dias até o recebimento do salário).

4. Tarefa: objetivos particulares que determinado consumidor possui em uma situação. Por exemplo, uma pessoa comprando um presente de casamento para um amigo constitui uma situação diferente em relação à compra para uso pessoal.

5. Estados antecedentes: os humores (ansiedade, alegria, excitação) ou condições temporais (dinheiro, cansaço) que o consumidor traz para a situação de consumo. Estados antecedentes diferem dos estados momentâneos, que ocorrem em resposta à determinada situação, assim como das feições individuais duradouras, como personalidade, por exemplo.

Fonte: Belk, R.W. ${ }^{10}$ citado em Engel et al. (1993)

A teoria dos traços se foca nas características ou estado mental dos indivíduos, tentando explicar o comportamento somente através destes fatores. $\mathrm{O}$ situacionismo, por sua vez, assume que o comportamento é amplamente dependente da situação. Ambos os paradigmas têm falhado na previsão do comportamento, quando são feitos estudos

\footnotetext{
${ }^{10}$ BELK, R.W. Situational Variables and Consumer Behavior. Journal of Consumer Research 2.

December, 1975, pp. 157-164.
} 
empíricos. Prova disso está no levantamento feito por Bowers ${ }^{11}$ citado em Punj \& Stewart (1983), no qual ele analisou os resultados de 11 estudos que examinam os efeitos da situação, do indivíduo e de sua interação. O autor concluiu, neste levantamento, que $12,71 \%$ da variância eram explicados por fatores individuais, comparados com $10,17 \%$ explicados pela situação. No entanto, o efeito conjunto (indivíduo + situação) foi responsável por $20,77 \%$ da variância.

O modelo interacionista, relacionado à influência situacional, de acordo com Punj \& Stewart (1983), se estrutura da seguinte maneira:

$$
\text { Comportamento }=\text { Situação }+ \text { Individuo }+(\text { Situação } x \text { Individuo })
$$

Portanto, o modelo interacionista não somente identifica os efeitos exclusivos do indivíduo e da situação, como também reconhece a presença de uma interação entre estes efeitos.

Para demonstrar a preocupação de numerosos pesquisadores sobre o efeito interacionista (indivíduo + situação) sobre o comportamento do consumidor, Punj \& Stewart (1983) apresentam uma tabela com as pesquisas realizadas a respeito e seus sumários (Tabela 6).

Como pode ser observado na Tabela 6 , o efeito conjunto dos fatores individuais e da situação é responsável, em grande parte dos estudos levantados por Punj \& Stewart (1983) sobre o assunto, por considerável porção da variância total.

11 BOWERS, K.S. Situacionism in Psychology: An Analysis and a Critique. Psychological Review, 80, September, 1973. pp. 307-336. 
Tabela 6: Efeitos interacionistas influenciando o processamento de informação e tomada de decisão do consumidor.

\begin{tabular}{|c|c|c|c|c|}
\hline Estudo & $\begin{array}{c}\text { Variável } \\
\text { dependente }\end{array}$ & $\begin{array}{c}\text { Fatores } \\
\text { individuais }\end{array}$ & $\overline{\text { Situação }}$ & Sumário das conclusões \\
\hline $\begin{array}{l}\text { Bither \& } \\
\text { Wright }^{12} \\
\text { citados em } \\
\text { Punj \& } \\
\text { Stewart } \\
(1983, \text { p. } \\
190)\end{array}$ & $\begin{array}{l}\text { mudança de } \\
\text { atitude }\end{array}$ & $\begin{array}{l}\text { Convicção } \\
\text { própria (self- } \\
\text { confidence) }\end{array}$ & $\begin{array}{l}\text { nível de } \\
\text { distração }\end{array}$ & $\begin{array}{l}\text { diferenças na conviç̧ão } \\
\text { própria influenciaram o efeito } \\
\text { da distração visual no } \\
\text { ajustamento da estrutura de } \\
\text { atitudes do receptor. Interação } \\
\text { entre distração e distração e } \\
\text { convicção própria foram } \\
\text { responsáveis por } 20 \% \text { da } \\
\text { variância total. O efeito } \\
\text { exclusivo da conviç̧ão própria } \\
\text { foi responsável por } \\
28 \text { \% da variância. } 0 \text { efeito } \\
\text { exclusivo do nivel de distração } \\
\text { não foi significativo. }\end{array}$ \\
\hline $\begin{array}{l}\text { Bozinoff \& } \\
\text { Cohen }{ }^{13} \\
\text { citados em } \\
\text { Punj \& } \\
\text { Stewart } \\
(1983, \mathrm{p} \\
190)\end{array}$ & $\begin{array}{l}\text { Importância de } \\
\text { atributos de } \\
\text { produto para } \\
\text { automóveis, } \\
\text { bibliotecas e } \\
\text { aparelhos de som }\end{array}$ & $\begin{array}{l}\text { Valores } \\
\text { pessoais } \\
\text { (medidos pela } \\
\text { Rokeach Value } \\
\text { Survey) }\end{array}$ & $\begin{array}{l}\text { situação de } \\
\text { uso }\end{array}$ & $\begin{array}{l}\text { valores pessoais foram } \\
\text { responsáveis por } 4-5 \% \text { da } \\
\text { variância da importância dos } \\
\text { atributos, situação de uso foi } \\
\text { responsável por } 2-4 \% \text { da } \\
\text { variância e a interação } \\
\text { (valores e situação de uso) foi } \\
\text { responsável por } 7-9 \% \text { da } \\
\text { variância. }\end{array}$ \\
\hline
\end{tabular}

continua...

\footnotetext{
12 BITHER, S.W. \& WRIGHT, P.L. The Self-Confidence-Advertising Response Relationship: A Function to Situational Distraction. Journal of Marketing Reserch, 10. May, 1973. pp. 146-152.

13 BOZINOFF, L. \& COHEN, R. An Interactionist Approach to Consumer Behavior. Working Paper $\mathbf{n}^{\circ}$ 113, College of Business Administration, Pennsylvania State University, University Park, PA. 1981.
} 
Tabela 6: Efeitos interacionistas influenciando o processamento de informação e tomada de decisão do consumidor.

\begin{tabular}{|c|c|c|c|c|}
\hline Est & $\begin{array}{l}\text { Variável } \\
\text { dependente }\end{array}$ & $\begin{array}{c}\text { Fatores } \\
\text { individuais }\end{array}$ & Situação & das conc \\
\hline $\begin{array}{l}\text { Coney \& } \\
\text { Harmon }^{14} \\
\text { citados em } \\
\text { Punj \& } \\
\text { Stewart } \\
(1983, \mathrm{p} . \\
190)\end{array}$ & $\begin{array}{l}\text { intenção de } \\
\text { compra para } 12 \\
\text { categorias de } \\
\text { produtos } \\
\text { (relógios, cintos, } \\
\text { câmaras, etc..) }\end{array}$ & $\begin{array}{l}\text { Dogmatismo } \\
\text { (mensurado } \\
\text { pela Rokeach } \\
\text { Dogmatism } \\
\text { Scale) }\end{array}$ & $\begin{array}{l}\text { situação de } \\
\text { compra: } \\
\text { compra para } \\
\text { uso pessoal } \\
\text { ou compra } \\
\text { para outros }\end{array}$ & $\begin{array}{l}\text { interação (situação + } \\
\text { dogmatismo) foi responsável } \\
\text { por aproximadamente } 10 \% \text { da } \\
\text { variação total na intenção de } \\
\text { compra. Efeitos exclusivos da } \\
\text { situação ou do dogmatismo } \\
\text { foram responsáveis, cada um, } \\
\text { por menos de } 1 \% \text { da } \\
\text { variância, sendo não } \\
\text { significativos. }\end{array}$ \\
\hline $\begin{array}{l}\text { Petty \& } \\
\text { Cacioppo }{ }^{15} \\
\text { citados em } \\
\text { Punj \& } \\
\text { Stewart } \\
(1983, \text { p. } \\
190)\end{array}$ & $\begin{array}{l}\text { atitude em } \\
\text { relação a } \\
\text { shampoo depois } \\
\text { de exposição à } \\
\text { propaganda }\end{array}$ & $\begin{array}{l}\text { nível de } \\
\text { envolvimento } \\
\text { em relação ao } \\
\text { produto } \\
\text { (importância do } \\
\text { produto para o } \\
\text { individuo) }\end{array}$ & $\begin{array}{l}\text { qualidade da } \\
\text { mensagem } \\
\text { (argumentos } \\
\text { fracos x } \\
\text { fortes), fonte }\end{array}$ & $\begin{array}{l}\text { presença de interação entre } \\
\text { tipo de argumento e nivel de } \\
\text { envolvimento. Argumentos } \\
\text { fortes produzem atitudes fortes } \\
\text { quando o nível de } \\
\text { envolvimento é alto; atitudes } \\
\text { menos favoráveis são } \\
\text { produzidas por argumentos } \\
\text { fracos em situações de alto } \\
\text { envolvimento. }\end{array}$ \\
\hline
\end{tabular}

continua...

\footnotetext{
${ }^{14}$ CONEY, K.A. \& HARMON, R.R. Dogmatism and Innovation: A Situational Perspective. Advances in Consumer Behavior, Vol. 6, ed. Willian Wilkie, Ann Arbor, MI: Association for Consumer Research, 1979. pp. 118-121.

${ }^{15}$ PETTY, R.E. \& CACIOPPO, J.T. Issue Involvement Can Increase or Decrease Persuasion by Enhancing Message-Relevant Cognitive Responses. Journal of Personality and Social Psychology, 37, October, 1979. pp. 1915-1926.
} 
Tabela 6: Efeitos interacionistas influenciando o processamento de informação e tomada de decisão do consumidor.

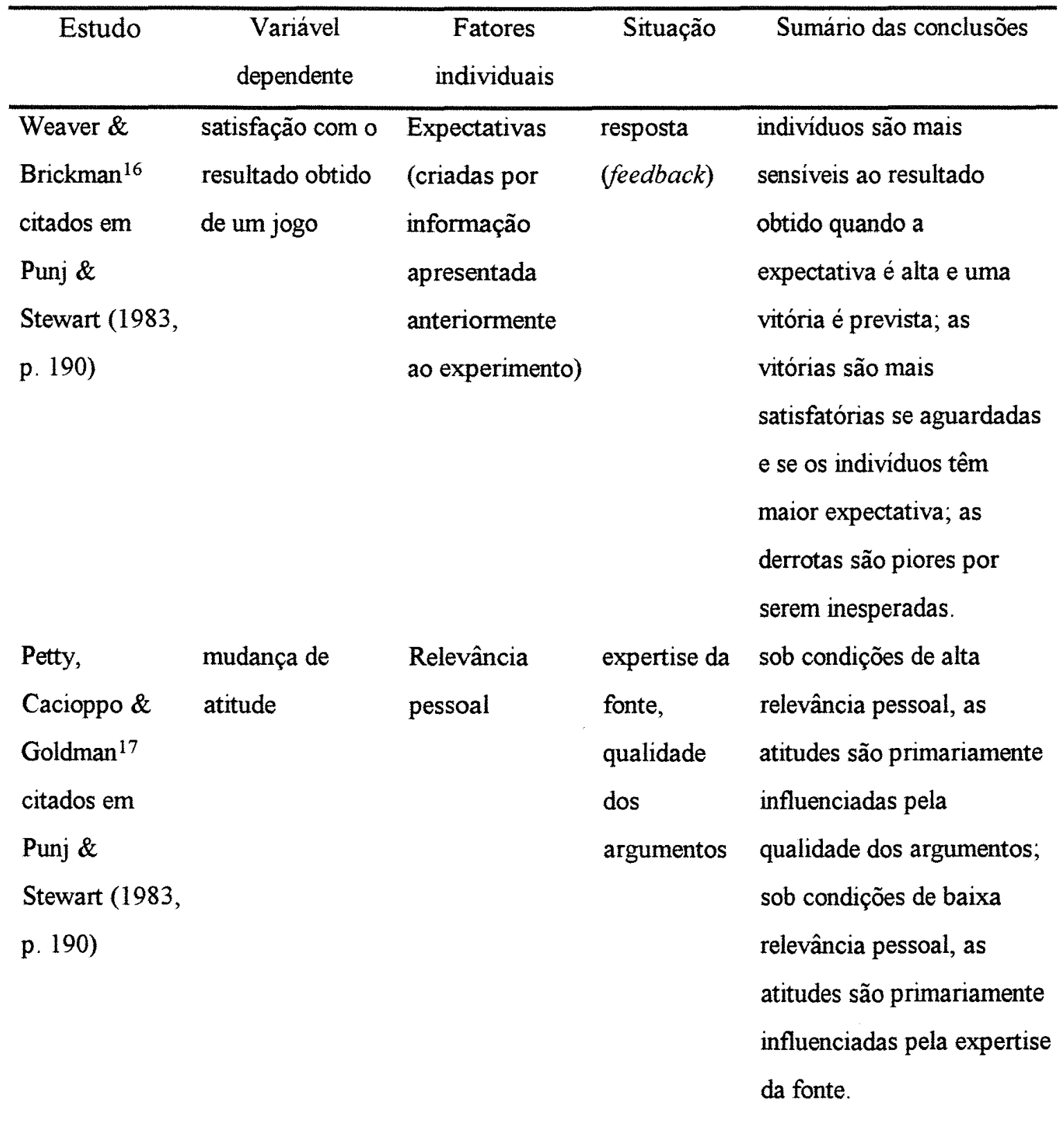

continua...

\footnotetext{
16 WEAVER, D.W. \& BRICKMAN, P. Expectancy, Feedback, and Disconfirmation as Independent Factors in Outcome Satisfaction. Journal of Personality and Social Psychology, 30, October, 1974. pp. 420-428.

${ }^{17}$ PETTY, R.E. \& CACIOPPO, J.T. \& Goldman, R. Personal Involvement as a Determinant of Argument-Based Persuasion. Journal of Personality and Social Psychology, 40, November, 1982. pp. 847-855.
} 
Tabela 6: Efeitos interacionistas influenciando o processamento de informação e tomada de decisão do consumidor.

\begin{tabular}{|c|c|c|c|c|}
\hline Estu & $\begin{array}{l}\text { Variável } \\
\text { dependente }\end{array}$ & $\begin{array}{l}\text { Fatores } \\
\text { individuais }\end{array}$ & Situação & Sumário das conclusões \\
\hline $\begin{array}{l}\text { Sandell }{ }^{18} \\
\text { citado em } \\
\text { Punj \& } \\
\text { Stewart } \\
(1983, \\
\text { p. 190) }\end{array}$ & $\begin{array}{l}\text { comportamento } \\
\text { de escolha para } \\
10 \text { bebidas (café, } \\
\text { água, cerveja, } \\
\text { etc..) }\end{array}$ & $\begin{array}{l}\text { análise de nível } \\
\text { individual de } 31 \\
\text { estudantes }\end{array}$ & $\begin{array}{l}7 \text { situações } \\
\text { relacionadas ao } \\
\text { comportamento } \\
\text { de interesse: } \\
\text { estar com muita } \\
\text { sede, sentir-se } \\
\text { sonolento } \\
\text { durante a tarde, } \\
\text { lendo os jornais } \\
\text { de manhã, etc. }\end{array}$ & $\begin{array}{l}\text { As interações pessoa- } \\
\text { situação e bebida-situação } \\
\text { foram responsáveis por } \\
3 \% \text { e } 40 \% \text { da variância } \\
\text { total, respectivamente. Os } \\
\text { efeitos isolados do } \\
\text { individuo e da situação } \\
\text { contribuíram com } \\
0,5 \% \text { e } 2,7 \% \text { da } \\
\text { variância total, } \\
\text { respectivamente. }\end{array}$ \\
\hline $\begin{array}{l}\text { Bishop \& } \\
\text { Witt }{ }^{19} \\
\text { citados em } \\
\text { Punj \& } \\
\text { Stewart } \\
(1983 \text {, } \\
\text { p. 190) }\end{array}$ & $\begin{array}{l}\text { comportamento } \\
\text { durante o periodo } \\
\text { de lazer }\end{array}$ & $\begin{array}{l}\text { análise de nivel } \\
\text { individual de } \\
140 \text { estudantes }\end{array}$ & $\begin{array}{l}10 \text { situações } \\
\text { relacionadas ao } \\
\text { comportamento } \\
\text { de interesse: } \\
\text { acordar } \\
\text { revigorado em } \\
\text { uma manhã de } \\
\text { sábado, } \\
\text { retornando da } \\
\text { biblioteca após } \\
\text { terminar um } \\
\text { trabalho, etc. }\end{array}$ & $\begin{array}{l}\text { O componente oriundo da } \\
\text { interação (pessoa-situação, } \\
\text { resposta-situação, e } \\
\text { pessoa-resposta) foi } \\
\text { responsável por } 39 \% \text { da } \\
\text { variância total. A } \\
\text { quantidade de variância } \\
\text { que pode ser atribuída às } \\
\text { pessoas e às situações, } \\
\text { exclusivamente, foi } \\
4,5 \% \text { e } 2 \% \text {, } \\
\text { respectivamente. }\end{array}$ \\
\hline
\end{tabular}

continua...

18 SANDELL, R.G. Effects of Attitudinal and Situational Factors on Reported Choice Behavior. Journal of Marketing Research, 5, November, 1968. pp. 405-408.

${ }^{19}$ BISHOP, D.W. \& WITT, P.A. Sources of Behavioral Variance During Leisure Time. Journal of Personality and Social Psychology, 16, October, 1970. pp. 352-360. 
Tabela 6: Efeitos interacionistas influenciando o processamento de informação e tomada de decisão do consumidor.

\begin{tabular}{|c|c|c|c|c|}
\hline Estudo & $\begin{array}{l}\text { Variável } \\
\text { dependente }\end{array}$ & $\begin{array}{c}\text { Fatores } \\
\text { individuais }\end{array}$ & Situação & Sumário das conclusões \\
\hline $\begin{array}{l}\text { Belk }^{20} \\
\text { citado em } \\
\text { Punj \& } \\
\text { Stewart } \\
\text { (1983, } \\
\text { p. 191) }\end{array}$ & $\begin{array}{l}\text { classificação de } \\
12 \text { filmes } \\
\text { hipotéticos em } \\
\text { uma escala de } 5 \\
\text { pontos }\end{array}$ & $\begin{array}{l}\text { análise de nível } \\
\text { individual de } \\
100 \text { estudantes }\end{array}$ & $\begin{array}{l}9 \text { situações } \\
\text { relacionadas a } \\
\text { ir ao cinema: } \\
\text { em uma noite, } \\
\text { durante a } \\
\text { semana, com } \\
\text { amigos do } \\
\text { mesmo sexo, } \\
\text { apenas alguma } \\
\text { coisa para } \\
\text { fazer, etc.. }\end{array}$ & $\begin{array}{l}\text { O componente advindo da } \\
\text { interação respondeu por } \\
\text { aproximadamente } 43 \% \text { da } \\
\text { variância total. Os efeitos } \\
\text { exclusivos do individuo e } \\
\text { da situação explicaram } \\
0,9 \% \text { e } 0,5 \% \text { da variância, } \\
\text { respectivamente. }\end{array}$ \\
\hline $\begin{array}{l}\text { Belk }^{21} \\
\text { citado em } \\
\text { Punj \& } \\
\text { Stewart } \\
(1983 \text {, } \\
\text { p. 191) }\end{array}$ & $\begin{array}{l}\text { intenções de } \\
\text { compra } \\
\text { relacionadas a } 10 \\
\text { estabelecimentos } \\
\text { de fast-food, em } \\
\text { uma escala de } 6 \\
\text { pontos }\end{array}$ & $\begin{array}{l}\text { análise de nível } \\
\text { individual de } 98 \\
\text { donas de casa } \\
\text { em uma } \\
\text { comunidade }\end{array}$ & $\begin{array}{l}10 \text { situações de } \\
\text { consumo de } \\
\text { fast-food: muito } \\
\text { cansada para } \\
\text { fazer o jantar, } \\
\text { convidados } \\
\text { inesperados } \\
\text { para jantar, } \\
\text { etc. }\end{array}$ & $\begin{array}{l}\text { O componente advindo da } \\
\text { interação respondeu por } \\
38 \% \text { da variância total. Os } \\
\text { efeitos exclusivos do } \\
\text { individuo e da situação } \\
\text { explicaram } 8 \% \text { e } 2 \% \text { da } \\
\text { variância, respectivamente. }\end{array}$ \\
\hline
\end{tabular}

${ }^{20}$ BELK, R.W. Application and Analysis of the Behavioral Differential Inventory for Assessing Situational Effects in Buyer Behavior. Advances in Consumer Research. Vol. 1. 1974b. pp. 158-161.

${ }^{21}$ BELK, R.W. The Objective Situation as a Determinant of Consumer Behavior. Advances in Consumer Research, Vol.2. 1975b. pp. 455-463. 
Tabela 6: Efeitos interacionistas influenciando o processamento de informação e tomada de decisão do consumidor.

\begin{tabular}{|c|c|c|c|c|}
\hline $\mathrm{Es}$ & $\begin{array}{l}\text { Variável } \\
\text { dependente }\end{array}$ & $\begin{array}{l}\text { Fatores } \\
\text { individuais }\end{array}$ & Sit & $\mathrm{Su}$ \\
\hline $\begin{array}{l}\text { Belk }^{22} \\
\text { citado em } \\
\text { Punj \& } \\
\text { Stewart } \\
(1983, \\
\text { p. 191) }\end{array}$ & $\begin{array}{l}\text { intenções de uso, } \\
\text { medidas por uma } \\
\text { escala de } 5 \\
\text { pontos } \\
\text { (extremamente } \\
\text { provável - nada } \\
\text { provável), para } \\
11 \text { produtos de } \\
\text { carne } \\
\text { (hambúrguer, } \\
\text { bife, frango, etc.) }\end{array}$ & $\begin{array}{l}\text { Análise de nível } \\
\text { individual de } \\
100 \\
\text { consumidores } \\
\text { em uma } \\
\text { comunidade }\end{array}$ & $\begin{array}{l}9 \text { situações } \\
\text { apropriadas } \\
\text { para o } \\
\text { comportamento } \\
\text { de interesse: } \\
\text { festa para } \\
\text { amigos, jantar } \\
\text { em um dia de } \\
\text { semana, etc.. }\end{array}$ & $\begin{array}{l}\text { O componente advindo da } \\
\text { interação respondeu por } \\
\text { aproximadamente } 39 \% \text { da } \\
\text { variância total. Os efeitos } \\
\text { exclusivos do individuo e } \\
\text { da situação explicaram, } \\
\text { cada um, aproximadamente } \\
5 \% \text { da variância. }\end{array}$ \\
\hline $\begin{array}{l}\text { Hornik }^{23} \\
\text { citado em } \\
\text { Punj \& } \\
\text { Stewart } \\
\text { (1983, } \\
\text { p. 191) }\end{array}$ & $\begin{array}{l}\text { gastos de tempo } \\
\text { em uma série de } \\
\text { atividades } \\
\text { (trabalho, } \\
\text { necessidades, } \\
\text { trabalho de casa, } \\
\text { e lazer) }\end{array}$ & $\begin{array}{l}\text { Características } \\
\text { demográficas } \\
\text { como sexo, } \\
\text { idade, familia, } \\
\text { renda, etc. }\end{array}$ & $\begin{array}{l}\text { variáveis } \\
\text { ambientais } \\
\text { como } \\
\text { temperatura, } \\
\text { tempo, presença } \\
\text { de outros } \\
\text { indivíduos, e } \\
\text { humor }\end{array}$ & $\begin{array}{l}\text { Interações entre pessoas e } \\
\text { variáveis situacionais } \\
\text { foram responsáveis por } \\
\text { proporções estatisticamente } \\
\text { significativas, da variância } \\
\text { total, no comportamento } \\
\text { temporal. Isto foi } \\
\text { especialmente verdadeiro } \\
\text { para atividades de lazer. }\end{array}$ \\
\hline
\end{tabular}

Fonte: Adaptado de Punj \& Stewart (1983, p. 190 e 191)

A conclusão de Punj \& Stewart (1983) foi, portanto, que um modelo de comportamento de escolha do consumidor que considere não somente as influências

\footnotetext{
22 BELK, R.W. (1974a). Op. cit. in Punj, G.H. \& Stewart, D.W. Op. cit p. 191.

${ }^{23}$ HORNIK, J. Situational Effects on the Consumption of Time. Journal of Marketing, 46 (Fall), 1982. pp. 44-55 in Punj, G.H. \& Stewart, D.W.. Op. cit p. 191
} 
individual e situacional, mas também a interação entre estas, seria mais útil, tanto no sentido descritivo, como em relação à sua capacidade de previsão, quando comparado com modelos que não consideram a presença de interações.

Utilizar um modelo deste tipo, no entanto, ainda de acordo com estes autores, não implica, necessariamente, na afirmação que os efeitos da interação serão sempre estatisticamente significativos, ou que serão responsáveis pela maior parte da variância no comportamento do consumidor. Em situações bem definidas e bem estruturadas, por exemplo, os efeitos situacionais podem aparecer como dominantes. Já em situações não tão estruturadas, ou não bem definidas, as diferenças individuais podem ser importantes na previsão do comportamento.

Dickson (1982) também adota uma visão interacionista, defendendo a análise do efeito da interação pessoa-situação, além dos efeitos individuais e situacionais, considerados isoladamente, ao se segmentar determinado mercado. Em seu estudo, este autor apresenta uma estrutura interessante, apresentada a seguir (Figura 5). Esta figura serve como ilustração da maneira através da qual se supõe ocorrer a influência da situação sobre o comportamento do consumidor, adotada neste trabalho.

A versão interacionista também é mencionada por Engel et al. (1993). Estes autores afirmam que a influência situacional pode variar de acordo com o individuo/ consumidor. Desta maneira, a noção de que os consumidores não são homogêneos, em relação ao seu padrão de resposta a fatores situacionais, deve ser considerada por ocasião da segmentação de determinado mercado.

Após a contextualização da influência situacional sobre o comportamento do consumidor, podemos prosseguir nossa discussão a respeito dos aspectos situacionais. 


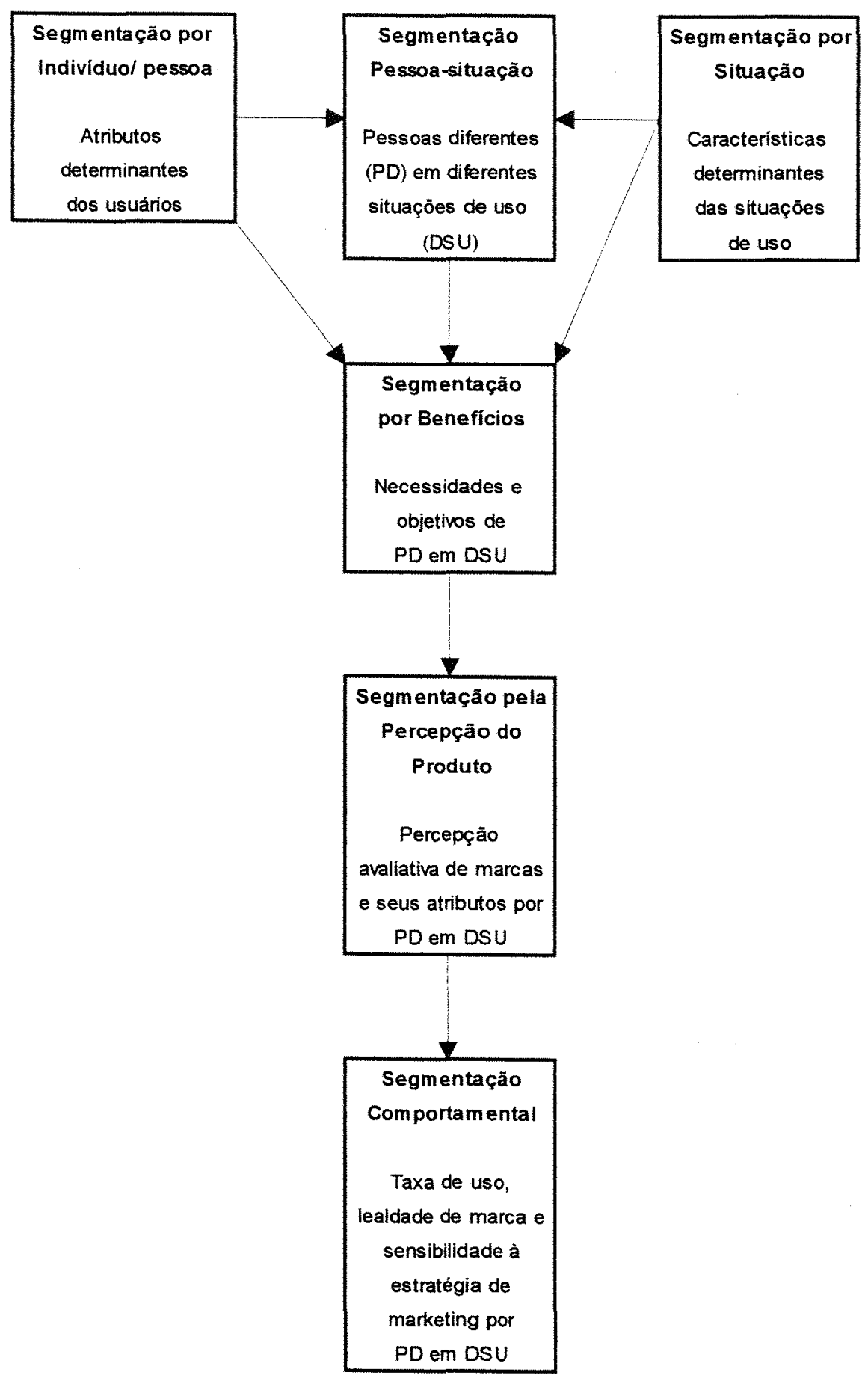

Figura 5: Segmentação por benefícios pessoa-situação.

Fonte: Dickson (1982, p. 60) 
De acordo com Engel et al. (1993), existem três tipos principais de situações que influenciam o consumo. São eles: comunicação, compra e situações de uso.

A situação de comunicação pode ser definida, de acordo com Engel et al. (1993), como os cenários nos quais o consumidor é exposto a comunicações pessoais ou não pessoais. Comunicações pessoais abrangeriam qualquer comunicação que um consumidor poderia ter com outro indivíduo, seja este um vendedor ou outro consumidor. A comunicação não pessoal, por sua vez, envolveria uma ampla gama de estímulos, como propaganda, programas e publicações voltadas ao consumidor.

Os autores destacam, visando ilustrar o impacto potencial dos efeitos situacionais na comunicação, situações que podem alterar a efetividade de propagandas veiculadas na televisão. Isto foi feito, segundo os autores, devido a importância deste meio (TV) para a propaganda e a existência de inúmeras pesquisas sobre o assunto. Neste contexto, tem-se a presença de inúmeros fatores podendo vir a influenciar o comportamento, tais como: presença de outros indivíduos durante a comunicação, nível de atenção, ruído, etc. De maneira geral, estas situações podem ser transferidas para os demais tipos de comunicação, que também sofrem influências situacionais. No caso de mídia impressa, além destes fatores, deve-se destacar a credibilidade de fonte, como importante influência situacional.

A situação de compra, segundo Engel et al. (1993), se refere aos cenários onde os consumidores adquirem bens e/ou serviços. A situação de compra, segundo estes autores, poderia ser dividida em três itens. São eles: ambiente de informação, ambiente de ponto de venda e influência do tempo.

O ambiente de informação está relacionado a todo tipo de dado, relacionado ao produto ou serviço, disponível ao consumidor. Estes dados se tornam mais importantes quando ocorre um processo de compra não habitual. Neste contexto, segundo estes 
autores, existem alguns fatores que podem vir a influenciar o comportamento. São eles: disponibilidade de informação, carga de informação (principalmente no que se refere à sobrecarga), formato da informação (maneira pela qual ela é organizada) e forma da informação (numérica ou não, por exemplo).

O ambiente do ponto de venda, também denominado atmosfera de loja, de acordo com Engel et al. (1993), pode causar uma série de efeitos sobre o comportamento dos consumidores, devendo, portanto, ser cuidadosamente analisado. Neste sentido, os autores também apresentam uma série de elementos que podem causar alterações no comportamento, tais como: música ambiente, layout da loja, cores utilizadas, materiais de ponto de venda (displays, por exemplo), presença de vendedores e lotação do ponto de venda.

A influência do tempo, ainda de acordo com Engel et al. (1993), representa um aspecto importante dos componentes situacionais. Isto seria particularmente verdadeiro para situações de compra. Neste sentido, teríamos influência de dimensões como: época do ano/ sazonalidade, tempo disponivel para a compra (pressões temporais), e tempo em relação a eventos anteriores (exemplo: indivíduos compram maior quantidade de alimentos quando estão com fome). O componente temporal também poderia influenciar a propaganda, modificando sua efetividade, de acordo com o horário de veiculação.

O terceiro tipo de situação de consumo, considerado por Engel et al. (1993), consiste na situação de uso. A situação de uso está relacionada àqueles ambientes onde ocorre o consumo.

Existem diversos fatores a serem comentados neste sentido. Em primeiro lugar, é interessante mencionar que o consumo, geralmente, ocorre em um cenário diferente daquele onde o produto foi adquirido, tanto fisicamente quanto no aspecto temporal. No entanto, mesmo quando as situações de compra e uso são distintas, existe uma forte 
influência da situação de uso "pretendida" no decorrer do processo de tomada de decisão.

O ambiente social que caracteriza uma situação de uso, de acordo com Engel et al. (1993), pode ter uma importância significativa no comportamento de consumo. Em relação a este aspecto, Stayman \& Deshpande (1989) realizaram uma pesquisa com vários grupos étnicos, nos EUA, na qual concluíram que o efeito do ambiente social é significativo no comportamento de escolha de grupos étnicos. Estudantes de origem chinesa, mexicana e inglesa tiveram diferentes percep̧̧ões a respeito da escolha de refeição apropriada para situações em que colegas ou pais estivessem presentes. Este estudo demonstra a influência do ambiente social, além da influência individual (tipo de indivíduo), no comportamento de consumo.

Engel et al. (1993) também apresentam um exemplo a respeito da influência do ambiente social no consumo de cerveja. De acordo com estes autores, o consumo de cerveja é sensível ao local de consumo do produto (público x privado). Desta maneira, 80 a $90 \%$ da cerveja importada, nos EUA, é consumida em locais onde outras pessoas podem ver o tipo de cerveja que determinado individuo consome (por exemplo: bares, restaurantes). No entanto, $70 \%$ do consumo domiciliar consiste de marcas nacionais, conforme pesquisa realizada por Higgins ${ }^{24}$, citado em Engel et al. (1993).

O tempo no qual o uso ocorre também pode afetar o comportamento, segundo Engel et al. (1993). Exemplificando, o consumo de alimento geralmente varia com o horário do dia em que se realizará, ou seja, dificilmente consome-se o mesmo tipo de alimento nas diferentes refeições diárias.

\footnotetext{
${ }^{24}$ HIGGINS, K.T. Beer Importers Upbeat about Future, Despite Warning Signs. Marketing News,
} October 25, 1985. 
Por fim, Engel et al. (1993) mencionam que a importância imputada a determinado atributo de um produto, assim como as crenças a respeito do desempenho do mesmo, podem também variar de acordo com o cenário (situação) de consumo. Podese considerar, neste sentido, as conclusões do estudo de Miller \& Ginter (1979), os quais indicam que compras de marcas específicas, importância dos atributos e conveniência percebida, variaram de acordo com as situações de uso. No estudo destes autores foram avaliadas oito cadeias de fast-food, nos EUA, em relação a importância de sete atributos selecionados, em quatro situações de consumo.

\subsubsection{Processo}

O segundo componente do modelo de Schiffman \& Kanuk (1994), consiste no processo. Este componente está relacionado com a maneira através da qual os consumidores tomam decisões. Para entender este processo deve-se considerar a influência de aspectos psicológicos no comportamento dos consumidores.

O campo psicológico, dentro do componente processo, representa as influências internas que afetam o processo de tomada de decisão pelo consumidor. As influências internas, segundo este autores, são: motivação, percepção, aprendizado, personalidade e atitudes. As definições apresentadas pelos autores para estes conceitos, estão sumarizadas na Tabela 7 .

Os autores salientam ainda outros dois conceitos chave, incluídos no campo psicológico, que atuam em função das percepções do consumidor. São eles: risco percebido e conjunto evocado.

O risco percebido é definido como "incerteza que os consumidores enfrentam quando não podem prever as conseqüências de suas decisões de compra", de acordo com Schiffman \& Kanuk (1994, p. 562). É importante salientar que os consumidores são 
influenciados apenas pelo risco que eles percebem, independentemente da existência ou não do risco propriamente dito. Risco não percebido por um consumidor, não importa o quão real ou perigoso seja, não influencia o comportamento desse consumidor.

Tabela 7: Definições para os componentes psicológicos do modelo de Schiffman \& Kanuk.

\begin{tabular}{ll}
\hline \multicolumn{1}{c}{ Componente } & Definição \\
\hline Motivação & "Força motriz dos indivíduos, que os impele para a ação. \\
& Esta força é produzida por um estado de tensão, existente \\
& devido a uma necessidade não satisfeita (p. 94)". \\
Percepção & "Processo pelo qual um indivíduo seleciona, organiza e \\
& interpreta estímulos, em direção à obtenção de uma figura \\
& significativa e coerente do mundo (p. 162)". \\
Aprendizado & "Processo através do qual os indivíduos adquirem \\
& conhecimento e experiência em relação à compra e ao \\
& consumo de produtos e/ou serviços, para usá-los em \\
Personalidade & comportamento futuro (p. 201)". \\
& "Características psicológicas internas que determinam e \\
& refletem como uma pessoa responde ao seu ambiente (p. \\
& 126)". \\
"Predisposição aprendida para agir de maneira & consistentemente favorável ou desfavorável em relação a um \\
& dado objeto (p. 240)".
\end{tabular}

Fonte: Adaptado de Schiffman \& Kanuk (1994)

Schiffman \& Kanuk (1994, p. 562 e 563) apresentam seis tipos de riscos usualmente percebidos pelos consumidores em uma situação de tomada de decisão. São eles: funcional, físico, financeiro, social, psicológico e temporal, exemplificados na Tabela 8. 
Tabela 8: Tipos de risco percebido pelo consumidor em situação de tomada de decisão.

\begin{tabular}{ll}
\hline \multicolumn{1}{c}{ Tipo } & \multicolumn{1}{c}{ Descrição } \\
\hline Funcional & Risco do produto não funcionar como esperado. Ex.: "A \\
& máquina de lavar louça vai realmente limpar minhas louças e \\
& panelas?". \\
Físico & Risco que o produto possa causar para a pessoa, e para outros \\
& indivíduos. Ex.: "O telefone celular é realmente seguro, ou \\
& emite algum tipo de radiação?". \\
Financeiro & Risco do produto não valer o que custou. Ex.: "A universidade \\
& vai realmente me ajudar a obter um emprego melhor?". \\
Social & Risco através do qual uma escolha inadequada possa causar um \\
& embaraço social para o consumidor. Ex.: "Este desodorante \\
& novo realmente elimina o odor da transpiração?". \\
& Risco de uma escolha inadequada ferir o ego do consumidor. \\
Psicológico & Ex.: "Eu vou realmente me orgulhar de convidar meus amigos \\
& para esta casa?". \\
& Risco do tempo gasto na busca do produto ser desperdiçado, \\
& devido a uma má performance do mesmo. Ex.: "Vou ter que \\
& realizar todo esforço de compra novamente?".
\end{tabular}

Fonte: Adaptado de Schiffman \& Kanuk (1994, p. 562 e 563)

Os consumidores, no entanto, desenvolveram estratégias para reduzir o risco percebido. Estas estratégias, apresentadas por Schiffman \& Kanuk (1994, p. 563), permitem, ao indivíduo, agir com confiança crescente quando tomam decisões de compra, mesmo que as conseqüências destas decisões ainda sejam, de alguma maneira, incertas. As estratégias mais comuns para redução de risco são:

1. Busca de informação (comunicação boca-a-boca, vendedores, propagandas nos meios de comunicação),

2. Lealdade a uma marca específica, 
3. Comprar uma marca conhecida,

4. Comprar em uma loja de boa reputação,

5. Comprar o modelo ou marca mais caro e

6. Procurar segurança através de garantias, amostras grátis, resultados de testes laboratoriais.

O conjunto evocado, também conhecido como conjunto considerado, refere-se às marcas específicas que um consumidor considera ao fazer uma escolha de compra, em determinada categoria de produto.

A Figura 6 apresenta uma descrição simples do conjunto evocado, como um subconjunto de todas as marcas disponíveis em determinada categoria de produto.

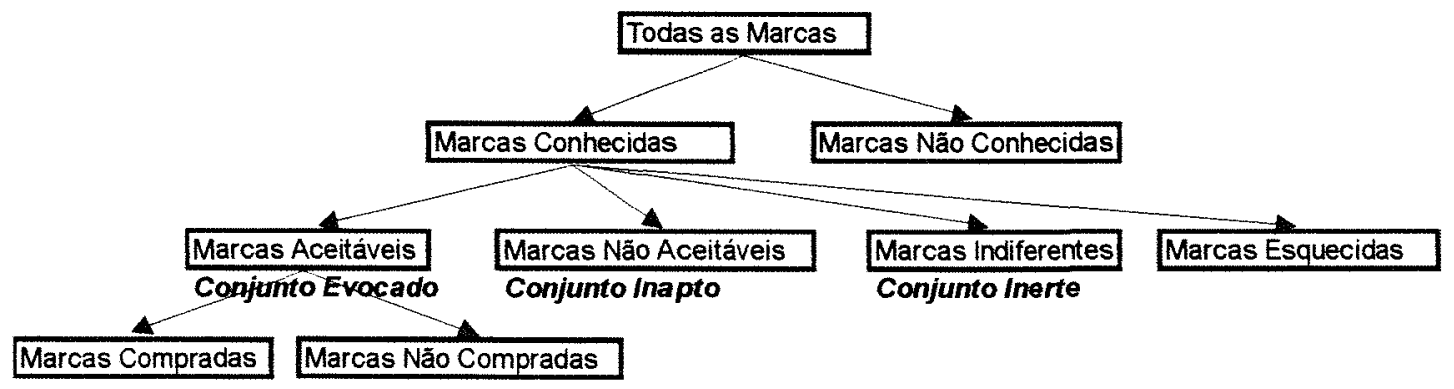

Figura 6: Conjunto evocado como um subconjunto do conjunto de todas as marcas em uma categoria de produto.

Fonte: Schiffman \& Kanuk (1994, p. 565)

Como se pode perceber, o conjunto evocado consiste em um pequeno número de marcas, com as quais o consumidor está acostumado, lembra e acha aceitáveis.

Após o exame dos fatores psicológicos que influenciam o comportamento do consumidor na tomada de decisão, os autores apresentam o componente processo de seu modelo de decisão. Segundo eles, o ato de tomar uma decisão de consumo consiste em 
três estágios: reconhecimento da necessidade, busca pré-compra e avaliação das alternativas.

O reconhecimento de uma necessidade, segundo Schiffman \& Kanuk (1994, p. 663), se torna provável quando um consumidor enfrenta determinado problema. Desta maneira, os autores definem este conceito como a "percepção, pelo consumidor, que há uma diferença entre o que é e o que deveria ser".

Os autores salientam que, entre os consumidores, parecem haver dois diferentes estilos de reconhecimento de problema. Alguns consumidores são tipo estado atual, percebendo que têm um problema apenas quando um produto não desempenha sua função adequadamente. Em contraste, outros consumidores são do tipo estado desejado, para os quais o desejo por alguma coisa nova pode ativar o processo de decisão.

A busca pré-compra começa, segundo os autores, quando o consumidor percebe que uma necessidade pode ser satisfeita pela compra e consumo de um produto. Um consumidor que sente uma necessidade de informação para basear sua escolha se encontra neste estágio do processo. Desta maneira, este conceito é definido como "um estágio no processo de tomada de decisão do consumidor, no qual o consumidor percebe uma necessidade e ativamente procura informação. A informação procurada está relacionada com produtos que ajudarão a satisfazer a necessidade (p. 665)".

O consumidor inicia sua busca por informação na própria memória (campo psicológico apresentado no modelo), só depois procura por fontes externas de informação a respeito de determinado produto. A experiência passada é considerada também como fonte interna de informação por Schiffman \& Kanuk (1994). Quanto mais experiência passada, menor quantidade de informação externa será necessária para que uma decisão seja tomada. No entanto, de maneira geral, a maioria das decisões dos 
consumidores está baseada em uma combinação de experiência passada (fontes internas) e apelos de marketing e informações não comerciais (fontes externas).

O risco percebido também pode influenciar este estágio do processo de decisão, ainda segundo Schiffman \& Kanuk (1994). Em situação de alto risco percebido, os consumidores se engajarão mais arduamente em busca e avaliação da informação; já em situações de baixo risco percebido, eles podem optar por táticas mais simples de coleta e avaliação da informação.

Finalmente, ainda sob o ponto de vista de Schiffman \& Kanuk (1994), temos a avaliação das alternativas pelo consumidor. Nesta situação o consumidor tende a usar dois tipos de informação: uma lista de marcas, entre as quais ele vai fazer a seleção, ou seja, o conjunto evocado, e os critérios que serão usados para avaliação de cada produto.

Os critérios que os consumidores usam para avaliar as marcas, que constituem o seu conjunto evocado, normalmente são expressos em termos de atributos importantes do produto.

Dentro da etapa de avaliação das alternativas, Schiffman \& Kanuk (1994) ainda apresentam as regras de decisão do consumidor. As regras de decisão do consumidor constituem em procedimentos usados para facilitar a escolha.

Existem regras de distribuição compensatórias e não compensatórias. No caso das regras de decisão compensatórias, os consumidores avaliam as alternativas em termos de cada atributo importante, dão pesos a cada atributo, somando os resultados. Desta maneira cada marca atingirá determinada pontuação, e o consumidor optará pela que tiver maior número de pontos. Como pode se notar, neste caso, um atributo negativo pode ser compensado por um positivo. 
Em contrapartida, regras de decisão não compensatórias não permitem esta compensação entre fatores negativos e positivos, ainda de acordo com Schiffman \& Kanuk (1994). Existem três tipos de regras de decisão não compensatórias, sumarizadas na Tabela 9.

Tabela 9: Tipos de regras de decisão não compensatórias

\begin{tabular}{lll}
\hline \multicolumn{1}{c}{$\begin{array}{c}\text { Regra de decisão } \\
\text { conjuntiva }\end{array}$} & \multicolumn{1}{c}{$\begin{array}{c}\text { Regra de decisão } \\
\text { disjuntiva }\end{array}$} & Regra de decisão lexicográfica \\
\hline "Regra de decisão não & "Regra de decisão não & "Regra de decisão não \\
compensatória, na qual & $\begin{array}{l}\text { compensatória, na qual } \\
\text { os consumidores }\end{array}$ & $\begin{array}{l}\text { compensatória, na qual os } \\
\text { consumidores, primeiramente, }\end{array}$ \\
estabelecem um padrão & estabelecem um padrão & ordenam os atributos em \\
mínimo aceitável, de & mínimo aceitável, de & termos de sua importância, \\
corte, para cada atributo & corte, para cada atributo & para então comparar as marcas \\
avaliado. Marcas que se & avaliado. Marcas que se & em relação ao atributo \\
encontrarem abaixo dos & encontrarem dentro ou & considerado mais importante. \\
padrões estabelecidos, & acima destes padrões, em & Se logo no primeiro atributo \\
em qualquer atributo, & qualquer atributo, são & uma marca se sobressai, ela é \\
são eliminadas & consideradas escolhas & selecionada. Caso contrário \\
(p. 658)". & adequadas (p. 660)". & passa-se à segunda alternativa, \\
& & e assim por diante (p. 662)". \\
\hline
\end{tabular}

Fonte: Schiffman \& Kanuk (1994)

Schiffman \& Kanuk (1994) também apresentam outro tipo de regra de decisão, considerada a mais simples de todas (affect referral). Neste caso, os consumidores fazem uma escolha com base na classificação geral percebida para determinada marca, em vez de avaliar cada atributo. Isto pode ocorrer para muitas decisões de compra, nas quais os consumidores mantém na memória as avaliações gerais das marcas. 


\subsubsection{Saída}

Finalmente, dentro do modelo de Schiffman \& Kanuk (1994), temos o componente saída. Segundo os autores, este componente é formado por duas atividades posteriores a decisão: comportamento de compra e avaliação pós-compra.

Existem dois tipos de comportamentos de compra: compras experimentais/testes ou compras repetidas. Quando compra-se uma quantidade menor que a habitual de um produto (ou marca), pela primeira vez, pode-se considerar esta compra como um teste. Portanto, este teste seria uma fase exploratória do comportamento de compra, na qual o consumidor deseja avaliar o produto através de seu uso direto.

Em contrapartida, se uma marca nova, em uma categoria de produto já estabelecida é, através de teste, tida como mais satisfatória ou melhor que as demais, os consumidores provavelmente irão repetir a compra.

É importante, no entanto, ressaltar que a fase experimental nem sempre é possível, como pode ocorrer no caso de bens duráveis, por exemplo. Neste caso o consumidor se moveria, da avaliação, diretamente para um comprometimento de longoprazo

Quando os consumidores usam determinado produto, principalmente durante uma compra experimental, eles avaliam a performance do produto frente as suas expectativas. Esta situação é denominada avaliação pós-compra por Schiffman \& Kanuk (1994)

As respostas a este tipo de avaliação podem ser: performance atual atinge as expectativas, deixando um sentimento neutro; performance excede as expectativas, causando satisfação; e performance fica abaixo das expectativas, causando insatisfação. 
A intensidade da análise pós-compra dependerá da importância da decisão e da experiência adquirida no uso do produto. Se um produto supera as expectativas, ele será provavelmente comprado novamente. No entanto, se o produto ficar aquém das expectativas, provavelmente serão procuradas alternativas mais adequadas. Portanto, a avaliação pós-compra retorna como experiência para o campo psicológico do consumidor, servindo como influenciadora de decisões de consumo futuras.

É importante ressaltar que, a análise do comportamento do consumidor não deve se encerrar após a compra de determinado produto, como ressaltado no decorrer deste modelo, uma vez que a experiência de uso de um produto ou serviço contribui para a satisfação do consumidor.

\subsubsection{Modelo de decisão de compra familiar}

O modelo de Schiffman \& Kanuk apresentado está focado na tomada de decisão por um consumidor individual. No entanto, muitas vezes a familia pode ser considerada uma unidade de tomada de decisão de consumo mais apropriada. Neste contexto, Sheth (1974) desenvolveu um modelo de tomada de decisão familiar. A seguir apresenta-se este modelo (Figura 7), também ressaltando sua características principais de acordo com seu idealizador (Sheth, 1974, pp. 17-33).

De acordo com este modelo, o consumo final de um bem e/ou serviço em uma família pode ser feito por: cada membro isoladamente, a família como um todo ou por uma unidade residencial.

Paralelamente, a decisão de consumo de uma família também pode ser de dois diferentes tipos. São eles: autônomo (por um membro isoladamente) ou conjunto (por vários ou todos membros da família). 


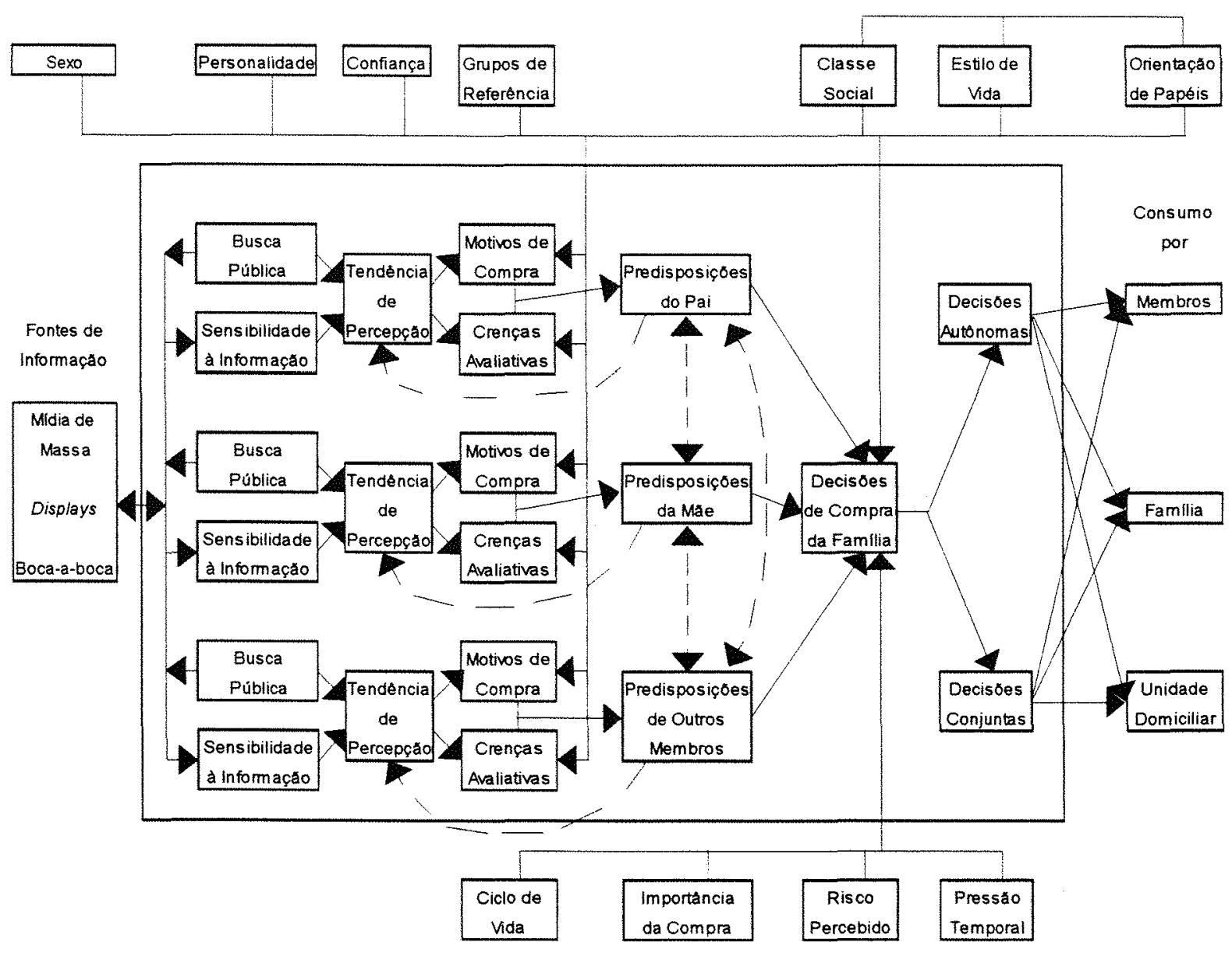

Figura 7: Modelo de decisão de compra familiar.

Fonte: Sheth (1974, p. 22-23)

O autor cita como exemplo o papel da mulher na aquisição de produtos, onde esta agiria, muitas vezes, como um agente de compra para todos os membros da família, uma vez que estes exerceriam influência na compra, através da expressão de suas preferências, mas não fariam a compra. Em outros casos poderia haver a ação completamente autônoma de um membro da família, mesmo que o consumo fosse coletivo. Este caso extremo ocorre, com maior probabilidade, no caso de produtos cuja marca não é visível no momento de consumo (Ex.: ingrediente de uma refeição). No entanto, de maneira geral, muitas decisões tendem a ser conjuntas quando o consumo é conjunto. 
Ainda com referência a decisões autônomas ou conjuntas, são apresentados diversos fatores que podem atuar nesta dimensão. Classe social, orientação de papéis, e estilo de vida, assim como a importância relativa da compra, o risco percebido e o fator tempo podem contribuir para a determinação de uma decisão autônoma ou conjunta. $\mathrm{O}$ sentido desta influência é apresentado na Tabela 10 .

Tabela 10: Fatores que determinam decisão conjunta.

\begin{tabular}{|c|c|}
\hline Fatores & Influência \\
\hline Classe social & $\begin{array}{l}\text { classe média apresenta maior número de } \\
\text { decisões conjuntas, quando comparada } \\
\text { com as classes alta e baixa, onde há maior } \\
\text { autonomia. }\end{array}$ \\
\hline Orientação de papéis & $\begin{array}{l}\text { determinação de papéis específicos dentro } \\
\text { de uma família leva, de maneira geral, a } \\
\text { uma maior autonomia na compra. }\end{array}$ \\
\hline Ciclo de vida da família & $\begin{array}{l}\text { decisões conjuntas são menos prováveis em } \\
\text { casais casados recentemente, quando } \\
\text { comparados a famílias com crianças. }\end{array}$ \\
\hline Risco percebido na compra & $\begin{array}{l}\text { quanto maior o risco percebido, maior a } \\
\text { probabilidade de haver uma decisão } \\
\text { conjunta. }\end{array}$ \\
\hline Importância da compra para família & $\begin{array}{l}\text { quanto maior a importância da aquisição } \\
\text { para a familia, maior a probabilidade de } \\
\text { haver uma decisão conjunta. }\end{array}$ \\
\hline Pressões temporais & $\begin{array}{l}\text { quanto maior pressão temporal houver, } \\
\text { menor a possibilidade de haver compra } \\
\text { conjunta. }\end{array}$ \\
\hline
\end{tabular}

Fonte: Adaptado de Sheth (1974, p. 29-30) 
Uma decisão de compra autônoma é uma função das predisposições de um indivíduo em relação a marcas específicas, sendo que estas estão relacionadas a motivos de compra e crenças oriundas da avaliação. De acordo com o autor, este conceito é baseado em três fatores: disponibilidade de informação no momento da decisão, sendo que as fontes de informação podem ser: mídia de massa, boca-a-boca e informação proveniente do conhecimento armazenado na memória de cada indivíduo; influência de outros membros da familia; e um conjunto de fatores antecedentes, tais como: personalidade, estilo de vida, classe social, orientação de papéis, e grupos de referência.

Vale ainda ressaltar que um membro, em situação de aquisição autônoma de produtos para consumo coletivo, costuma levar em consideração os requerimentos e preferências específicos de outros membros da família.

O foco deste modelo está no processo de decisão conjunta familiar para aquisição de produtos. Neste contexto, é dada especial atenção aos papéis específicos no processo. Os papéis apresentados pelo autor são: iniciador, indivíduo encarregado de obter informação e indivíduo encarregado da compra.

$\mathrm{O}$ ator que atuará como iniciador do processo está relacionado ao estilo de vida de uma família, assim como à orientação de papéis. No entanto, se um membro da familia for dominante, ele tem grande probabilidade de ser o iniciador do processo. O segundo papel está relacionado ao indivíduo encarregado de obter as informações. Nesta situação, o autor afirma que diversos estudos têm indicado a intensidade de participação dos membros de uma família, proporcional a sua experiência em relação aos diferentes aspectos de uma decisão. Finalmente, o terceiro papel está relacionado ao membro da familia encarregado de fazer a compra.

Em relação aos diversos atores no processo de decisão familiar (unidade de tomada de decisão), Kotler (1992, p. 224) também ressalta a existência de vários papéis 
de compra. A análise deste autor difere um pouco da de Sheth, pois são apresentados cinco papéis de compra. São eles: iniciador ("pessoa que primeiro deu a idéia de comprar determinado produto ou serviço"); influenciador ("pessoa cujos pontos de vista ou advertências têm algum peso para se chegar à decisão final"); decisor ("pessoa que determina, por último, parte ou a completa decisão de compra: se se deve comprar, o que, como e onde comprar"); comprador ("pessoa que faz a compra"); e usuário ("pessoa que consome ou utiliza o produto ou o serviço").

Finalmente, para completar a análise de Sheth, é apresentada a possibilidade de existência de conflito em uma situação de compra conjunta. De acordo com este autor, a condição necessária para existência de conflito é a tomada de decisão conjunta. Já as condições suficientes de conflito, entre membros de uma família, estariam relacionadas a: diferentes objetivos e diferenças na percepção sobre as alternativas ou objetos-alvo relevantes. Estes conflitos poderiam ser resolvidos, de acordo com o autor, através de: resolução do problema, persuasão, barganha ou solução política.

A resolução do problema ocorre quando os membros de uma familia concordam a respeito da necessidade, mas discordam em relação às marcas que parecem ser mais adequadas. Este tipo de solução se caracteriza pela procura ativa por informação, por parte dos membros, além de maior discussão a respeito das informações já disponíveis.

Quando os membros de uma familia discordam a respeito de critérios específicos, através dos quais as marcas são avaliadas, a solução pode ser através de persuasão.

$\mathrm{Na}$ situação onde a posição dos membros de uma família é fixa, o conflito pode vir a ser resolvido através de barganha, ou seja, permite-se a um indivíduo agir de forma autônoma, em troca da garantia de favores aos demais membros. 
Finalmente, no caso onde ocorrem desacordos em relação a princípios fundamentais, como por exemplo, sobre o estilo de vida da família, a solução pode se dar através de dissolução da unidade familiar ou de solução política. A solução política consiste em formação de subgrupos na família, isolando o indivíduo com o qual há conflito.

\subsubsection{Estágios do processo de tomada de decisão de compra do consumidor}

Para completar a análise do comportamento do consumidor, seria interessante, em relação aos objetivos deste estudo, destacar os estágios do processo de decisão de consumo

Neste aspecto, Santos (1994) apresenta uma descrição interessante do processo de compra do consumidor. Santos (1994) divide o processo de compra em três fases: pré-compra, compra e pós-compra, como pode ser observado na Figura 8.
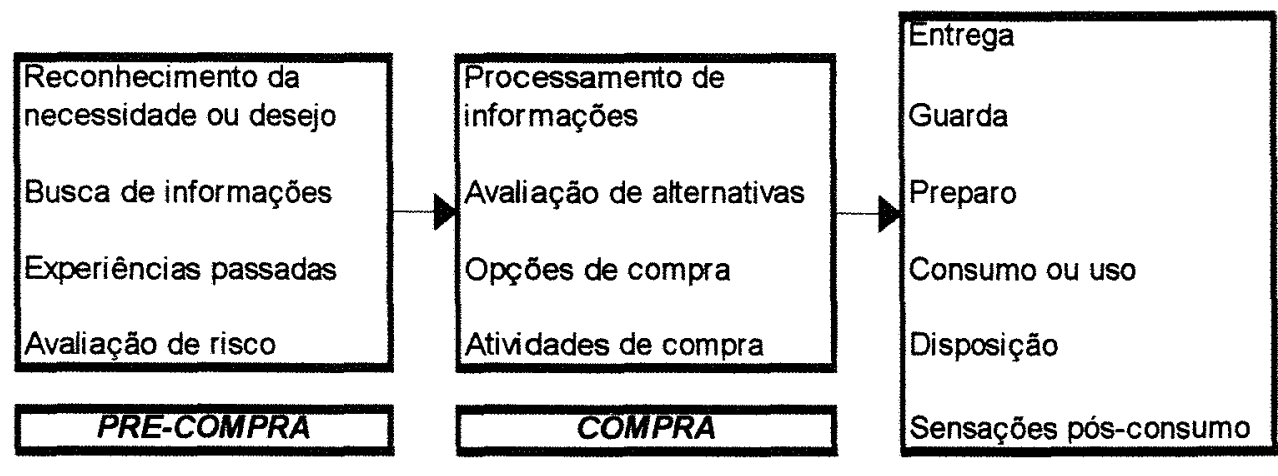

POS-COMPRA

Figura 8: Estágios do processo de decisão de compra do consumidor.

Fonte: Santos (1994, p. 33)

Ainda segundo Santos (1994), o consumidor nas atividades que precedem a compra propriamente dita analisa diversos aspectos, após reconhecer uma necessidade ou 
desejo. Em uma fase inicial, o consumidor buscará informações adicionais visando melhor caracterizar como atender sua necessidade ou desejo. Nesta fase, o consumidor costuma ficar mais atento e aberto a fontes de informação e a outras pessoas visando atenuar eventuais riscos percebidos. Também poderão ser resgatadas experiências anteriores, se existirem, que possam estar relacionadas com a necessidade sentida.

Em um segundo estágio, o da compra propriamente dita, o consumidor avalia as alternativas a partir das informações colhidas no estágio inicial. Nesta fase, também ocorrem as opções de compra e as atividades visando à aquisição da alternativa selecionada.

O estágio pós-compra, terceira fase do processo, ainda segundo este autor, envolve várias atividades relacionadas com a manipulação e consumo do item adquirido. Nesta fase, o consumidor acumulará importantes sensações associadas com o uso, preparo, guarda e, até, a manutenção e disposição do bem. Este estágio é bastante importante, pois pode vir a influenciar as atitudes e comportamentos futuros dos consumidores.

\subsubsection{Modelo simplificado do processo de compra}

A partir dos modelos estudados, considerando também as fases do processo de decisão de compra do consumidor, conforme apresentado por Santos (1994), um modelo simplificado de comportamento de consumo foi apresentado (Figura 9). Este modelo será utilizado como base para o desenvolvimento do presente estudo.

Este modelo, considerado adequado aos objetivos deste estudo, está dividido em três fases, conforme proposto por Santos (1994). Assim sendo, o processo de compra se encontra dividido em pré-compra, compra e pós-compra. 


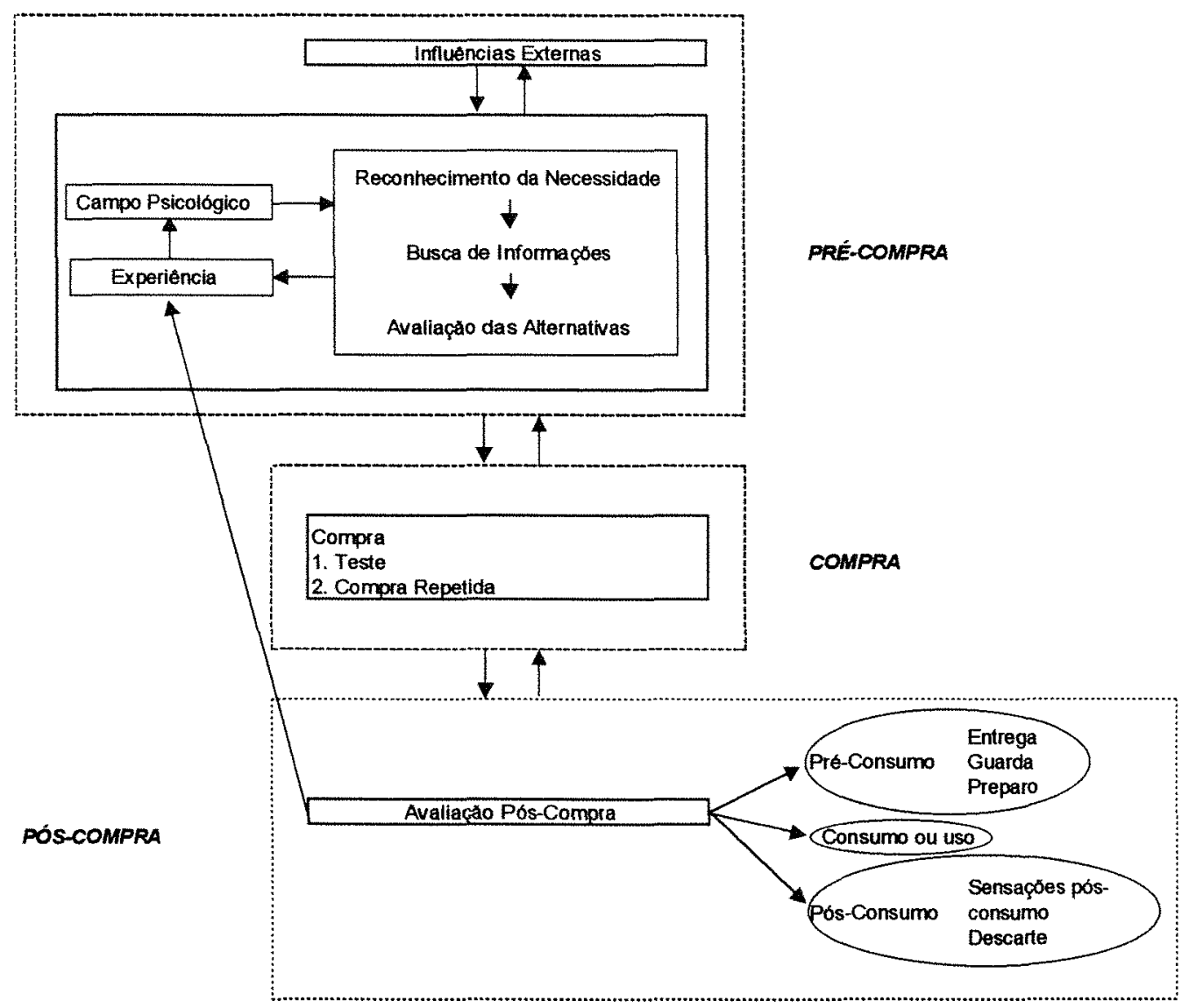

Figura 9: Modelo simplificado do processo de compra.

A influência do modelo de Schiffman \& Kanuk (1994), considerado também bastante adequado ao estudo do comportamento de consumo de bens e serviços em geral, também pode ser notada, com algumas adaptações, principalmente no que se refere à divisão do processo em três fases. No modelo simplificado proposto, considera-se, como fase de pré-compra, as fases de entrada e processo de tomada de decisão do modelo de Shiffman \& Kanuk. A fase de saída, no entanto, foi subdividida em duas fases: compra e pós-compra. Esse procedimento foi adotado por ser considerado mais adequado ao estudo do consumo de frutas, onde a fase de pós-compra assume grande importância. Essa fase foi ressaltada pois existem fatores importantes a serem considerados, como o pré-consumo, o consumo propriamente dito e o pós-consumo. 
$\mathrm{O}$ pré-consumo está relacionado à entrega, armazenamento e preparo, se houver, do produto. Já em relação ao pós-consumo, é importante ressaltar que, além das sensações relacionadas ao consumo do produto, tem-se o descarte, muito importante para o caso específico de frutas, devido à alta perecibilidade do produto.

Vale a pena salientar que supõe-se, de acordo com o modelo de tomada de decisão familiar de Sheth (1979), que a tomada de decisão em relação ao consumo de frutas seja considerada autônoma, neste estudo. Desta maneira um membro da família tomaria uma decisão autônoma sobre as frutas a serem consumidas ou não, levando em conta as preferências dos outros membros. Estamos, portanto, considerando que o ator encarregado da compra tomaria a decisão de consumo.

Com contribuições destes modelos, o modelo simplificado torna-se mais adequado para a análise do comportamento de consumo específico para frutas. A divisão do modelo em três partes (pré-compra, compra e pós-compra) facilita o estudo do comportamento de consumo de frutas, principalmente devido a um maior detalhamento da fase de pós-compra, que aborda também o item descarte, considerado bastante importante para o produto em questão, conforme mencionado anteriormente.

\subsubsection{Sumário e contribuições}

Como foi visto, neste primeiro item, foi feita uma revisão de literatura a respeito do processo de tomada de decisão de compra pelos consumidores.

Devido às suas características, foi adotado o modelo de Schiffman \& Kanuk (1994) como ponto de partida da análise. Um modelo de decisão de compra familiar também foi apresentado, uma vez que o consumo do produto estudado normalmente ocorre em unidades domiciliares. Finalmente, foram ressaltados os estágios do processo de decisão de compra, considerados importantes para o estudo do consumo do item em 
questão. A partir deste material, foi elaborado um modelo simplificado do processo de compra, considerado mais adequado para análise do consumo específico de frutas.

Desta maneira, a contribuição deste item do estudo, se dá através do fornecimento de um modelo, a ser seguido na análise específica do consumo de frutas.

\subsection{Comportamento de consumo de frutas}

O comportamento de consumo de um individuo, em relação ao item frutas, será detalhado, nesta seção, com base no modelo simplificado apresentado anteriormente (Figura 9). Assim sendo, esta seção será dividida em 3 partes, com o objetivo de facilitar a exposição do tema. Em um primeiro momento serão apresentados alguns aspectos relacionados à pré-compra. Posteriormente serão apresentados aspectos relacionados à fase de compra. Finalmente, serão vistos aspectos do estágio de pós-compra.

\subsubsection{Pré-compra}

Para facilitar a exposição do assunto, a fase de pré-compra será dividida em três itens: influências externas, influências internas e processo de tomada de decisão.

\subsubsection{Influências externas}

As influências externas consideradas neste estudo correspondem ao item entrada do modelo de Schiffman \& Kanuk (1994). Assim sendo, os principais tipos de influências externas consistiriam em atividades de marketing das empresas, que visam comunicar os beneficios de seus produtos ou serviços a consumidores potenciais, e influências socioculturais, que afetam a decisão de compra do consumidor. 


\subsection{Atividades de marketing}

As atividades de marketing de uma empresa, segundo Schiffman \& Kanuk (1994), assumem a forma de estratégias específicas de composto de marketing (marketing-mix), consistindo em: próprio produto (embalagem, tamanho, garantias etc..); propaganda na mídia de massa, marketing direto, venda pessoal e outros esforços promocionais; política de preços; e seleção dos canais de distribuição, para movimentar o produto do fabricante para o consumidor final.

Em relação ao item frutas, foram levantados alguns aspectos em relação a possíveis atividades de marketing de uma empresa.

No caso do item frutas, segundo Barizon ${ }^{25}$ citado em Nogueira (1989), em relação ao produto, a limpeza e arrumação das áreas onde estão expostos as frutas são fundamentais, pois dão ao cliente a sensação de ser o primeiro a chegar ao local. Assim sendo, principalmente no caso de vendas a granel, recomenda-se, além da arrumação constante, a exposição de produtos em menores quantidades, para evitar o aumento dos danos devido ao manuseio.

A predominância das vendas a granel, ainda de acordo com Barizon, deriva do hábito brasileiro de examinar a mercadoria que adquire. Apesar disso, a pré-embalagem de produtos frutícolas, uma exigência de consumidores de países mais desenvolvidos, tem ganhado também espaço cada vez maior no mercado brasileiro, de acordo com Nogueira (1989), em função de uma série de vantagens, principalmente garantia de qualidade e higiene. Além disso, apesar da embalagem elevar o custo do produto, ela contribui para diminuição do nível de perdas (impede o manuseio excessivo por parte dos consumidores), além de facilitar o processo de comercialização.

\footnotetext{
${ }^{25}$ BARIZON, P. Entrevista citada no artigo Know-how e qualidade conduzem ao lucro. Superhiper. Outubro, 1989. pp. 156-162.
} 
Outra forma de apresentação do produto, de acordo com Bennett (1994a), são as frutas pré-cortadas e embaladas. Este tipo de item tem se destacado em países desenvolvidos, como nos EUA, devido à sua potencial lucratividade. Bennett (1994d) ainda destaca que, até o ano 2000, os produtos pré-cortados e saladas pré-preparadas irão responder por mais de $20 \%$ das vendas no setor de frutas e verduras de determinados pontos de venda, nos EUA. No entanto, esta perspectiva otimista está vinculada ao manuseio adequado dos produtos pré-cortados.

Ainda a respeito do produto, uma tendência que têm surgido nos EUA é a necessidade de informações nutricionais presentes na embalagem de frutas ou dispostas junto ao produto, no caso de venda a granel. Informações nutricionais, no caso, seriam: nome da fruta; tamanho da porção; calorias por porção; proteínas, carboidratos, gordura e sódio por porção; e porcentagem das recomendações diárias (dos EUA) para ferro, cálcio e vitaminas A e C por porção, de acordo com Bennett (1994c).

A promoção de frutas pode ocorrer a nível amplo, como no caso de promover este item, de maneira geral, sem vinculação a uma empresa específica. Um exemplo deste fenômeno pode ser observado através da campanha "5 por dia" ( 5 a day), patrocinada pela Produce for Better Health Fundation (PBH) e pelo Nacional Cancer Institute (NCI), com grande apoio por parte de indústrias do setor hortifrutigranjeiro e pontos de venda. Esta campanha foi veiculada em diversos pontos de venda, nos EUA. Seu objetivo seria aumentar o consumo de frutas, vegetais e sucos naturais em todas as suas formas (frescos, congelados e enlatados), com o objetivo de melhorar a saúde da população e reduzir o risco de câncer (do tipo relacionado à dieta) e outras doenças. Em termos numéricos, o objetivo desta campanha seria aumentar o consumo destes itens de 3,5 porções (média atual nos EUA) para 5 porções diárias, conforme apresentado por Elman (1993). 
No entanto, as promoções ocorrem, de maneira geral, a nivel de empresas ou pontos de venda específicos. Além disso, quando consulta-se a literatura especializada, também percebe-se uma tendência de predomínio das promoções no ponto de venda, neste setor (merchandising). Como exemplo, pode-se citar: apresentação do setor de frutas e verduras de maneira a lembrar um mercado antigo de frutas, como ocorreu em uma pequena cadeia de lojas nos EUA, de acordo com Bennett (1993); display chamativo, inclusive com a colocação de um trator no local, para promover melões, em loja do Texas, EUA, ainda citado por Bennett (1994b); colocação de uma carroça com 75 anos e um espantalho, em tamanho natural, no setor de frutas e verduras, com itens produzidos na região ao redor, a preços especiais, no Tennessee, EUA (Supermercado Moderno, 1991b).

Também podem ser encontradas, na literatura, menções de promoções de itens específicos, como determinada marca de um produto. Este fenômeno pode ser comprovado pela campanha da empresa Frunorte, que introduziu no mercado brasileiro o conceito de fruta com marca, muito utilizado no exterior. Isto ocorreu através da campanha "Peça fruta pelo nome". De acordo com uma pesquisa realizada pela empresa, durante uma promoção em um supermercado, a campanha obteve "ótima receptividade no mercado"(Supermercado Moderno, 1991a).

Outro exemplo encontrado, a respeito da promoção de produtos específicos, está no lançamento de maçãs especiais para crianças, com tamanho adequado a esta faixa etária. Estas maçãs serão comercializadas com a marca "Turma da Mônica" em embalagem especial, sendo também pré-lavadas, podendo ser consumidas com casca (Superhiper, 1994b).

Finalmente, ao analisar-se o preço dos produtos, é importante que se observe o coeficiente de elasticidade-preço da demanda por frutas, medido no ponto de dispêndio médio familiar. Nesse caso, de acordo com a Secretaria de Agricultura e Abastecimento 
do Estado de São Paulo (1992), a elasticidade é maior que a unidade (demanda elástica). Em conseqüência, a modificação nos preços irá refletir mais do que proporcionalmente nas aquisições. Porém, calculando-se o coeficiente de elasticidade por classe de despesa familiar, ainda de acordo com dados apresentados pela Secretaria de Agricultura e Abastecimento do Estado de São Paulo (1992), obtém-se os seguintes resultados: 3,27 a 1,06, nas classes de despesas até 7 salários mínimos; aproximadamente 1,00 nas classes de despesas entre 7 e 10 salários mínimos; e menor que a unidade apenas nas classes de despesas superiores a 30 salários mínimos.

Pode-se estimar, a partir da elasticidade-preço da demanda, a estratégia mais adequada de preços a ser adotada, de acordo com o mercado alvo. Se a população de baixa renda é o objetivo, uma política de diminuição de preços tende a ser vantajosa. Por outro lado, se o mercado alvo é a camada da população com maior poder aquisitivo, um aumento dos preços pode vir a gerar retornos mais atraentes.

\subsection{Ambiente sociocultural}

O ambiente sociocultural também influencia as decisões de compra do consumidor. Conforme observado anteriormente, de acordo com Schiffman \& Kanuk (1994), o ambiente sociocultural seria constituído por: família, fontes informais e outras fontes não comerciais de informação, classe social, cultura e subcultura.

No caso específico de frutas, por tratar-se de um alimento, existem modificações ambientais importantes, que estão ocorrendo, e que exercem forte influência no consumo deste item, merecendo, portanto, uma discussão adequada.

Mudanças na faixa etária da população, estilos de vida, renda e novos comportamentos em relação a segurança alimentar, alimentos não prejudiciais à saúde e demanda por conveniência têm alterado drasticamente o mercado de alimentos, 
principalmente nos países desenvolvidos, onde uma economia mais estável permite uma observação menos destorcida destas influências.

Manchester (1992) apresenta diversas mudanças ambientais e suas conseqüências para o marketing, nos EUA, que estão sumarizadas na Tabela 11.

Tabela 11: Causas das mudanças ambientais e suas conseqüências no mercado de alimentos.

\section{CAUSAS DE MUDANÇAS}

Residências com menor número de habitantes: menos crianças e maior número de pessoas morando sozinhas

$\checkmark$ Maior renda; maior número de pessoas remuneradas por residência

Novos conceitos a respeito de saúde e alimentação

\section{MUDANÇAS NO MERCADO}

$\checkmark$ Boom dos supermercados (meados da década de 60)

$\checkmark$ Diversificação dos tipos de supermercados (baixos preços $x$ maior variedade de produtos)

$\checkmark$ Número de refeições fora de casa praticamente dobrou; crescimento principalmente do setor de fast food

Fonte: Adaptado de Manchester (1992, p. V)

Cannon (1992) apresenta também o relacionamento das mudanças ambientais com o consumo de alimentos, na Inglaterra. As mudanças ambientais, denominadas pelo autor como forças de mercado, são: alteração do papel da mulher na estrutura familiar; redução no ciclo de vida dos produtos; modificação nos hábitos alimentares e na maneira de preparar os alimentos; alteração na estrutura da população, sendo a mudança mais dramática, neste caso, o aumento de unidades familiares com somente um indivíduo. $\mathrm{O}$ autor também ressalta a transformação na faixa etária da população. Todos estes fatores irão alterar o padrão de consumo de alimentos. $O$ autor ainda menciona que estas 
tendências são semelhantes nos EUA e na maior parte da Europa, como já foi ressaltado anteriormente.

No caso brasileiro seria interessante apresentar alguns dados a respeito do ambiente, para usá-los como base para verificação das tendências apresentadas por autores estrangeiros. Em relação à renda, a Pesquisa Nacional por Amostra de Domicílios - PNAD apresenta a distribuição das pessoas de dez anos ou mais de idade, de acordo com o nível de rendimento, de 1981 a 1990 e em 1993 e 1995 (Tabela 12).

De acordo com a Tabela 12, poderíamos dizer que houve indícios de um pequeno aumento da renda no período de 1981 a 1995, por indivíduo, no Brasil, no entanto, não se pode afirmar que estes dados sejam realmente significativos

A situação da renda por indivíduo também é apresentada para o estado de São Paulo (Tabela 13).

Em relação aos dados de renda individual no estado de São Paulo, apresentados na Tabela 13, pode-se perceber, uma pequena tendência de aumento da renda no período de 1978 a 1988, talvez até mais significativa que a apresentada para o Brasil (Tabela 12).

O número de pessoas ocupadas por familia também aparece nos dados da PNAD (1990a) - Tabela 14 
Tabela 12: Distribuição percentual das pessoas de 10 anos ou mais de idade, segundo as classes de rendimento mensal, 1981/89 - Brasil.

\section{Classe}

de

$\begin{array}{llllllllllll}\text { Rendi- } & 1981 & 1983 & 1984 & 1985 & 1986 & 1987 & 1988 & 1989 & 1990 & 1993 & 1995\end{array}$ mento

Mensal

$\left({ }^{*}\right)$

\begin{tabular}{lccccccccccc}
\hline Até 1 & 20,2 & 22,3 & 21,6 & 21,9 & 19,4 & 19,0 & 20,9 & 19,6 & 17,5 & 21,5 & 16,4 \\
1 a 2 & 14,4 & 13,8 & 13,8 & 14,2 & 13,8 & 14,0 & 14,8 & 13,7 & 12,8 & 14,0 & 14,3 \\
2 a 5 & 13,2 & 12,5 & 13,3 & 13,5 & 15,7 & 16,2 & 14,4 & 15,5 & 16,1 & 13,9 & 16,0 \\
5 a 10 & 4,1 & 4,6 & 4,8 & 5,2 & 5,8 & 5,8 & 5,3 & 5,8 & 7,3 & 5,0 & 6,9 \\
10 a 20 & 1,7 & 1,9 & 2,0 & 2,2 & 2,7 & 2,8 & 2,7 & 3,1 & 3,5 & 2,2 & 3,2 \\
Mais & & & & & & & & & & & \\
de 20 & 0,7 & 0,8 & 0,9 & 1,0 & 1,3 & 1,4 & 1,4 & 2,0 & 2,0 & 1,1 & 1,7
\end{tabular}

Sem

rendi-

$\begin{array}{llllllllllll}\text { mento } & 45,4 & 43,9 & 43,4 & 41,8 & 41,0 & 40,4 & 40,0 & 39,9 & 40,4 & 41,2 & 40,7\end{array}$ $(* *)$

Sem

$\begin{array}{llllllllllll}\text { decla- } & 0,3 & 0,2 & 0,2 & 0,2 & 0,3 & 0,4 & 0,5 & 0,4 & 0,4 & 1,1 & 0,8\end{array}$ ração

$\begin{array}{llllllllllll}\text { Total } & 100 & 100 & 100 & 100 & 100 & 100 & 100 & 100 & 100 & 100 & 100\end{array}$

Fonte: Adaptado da PNAD (1990a, p.72); PNAD (1993, p.92); PNAD (1996, p. 62); PNAD (1995, tabela 4.1)

(*) Salários mínimos até 1986 e em 1989, 1990, 1993 e 1995 e pisos nacionais de salários em 1987 e 1988

${ }^{* *}$ Inclusive as pessoas que recebem somente em beneficios 
Tabela 13: Distribuição percentual das pessoas de 10 anos ou mais de idade, segundo as classes de rendimento mensal, 1979/88 - Estado de São Paulo.

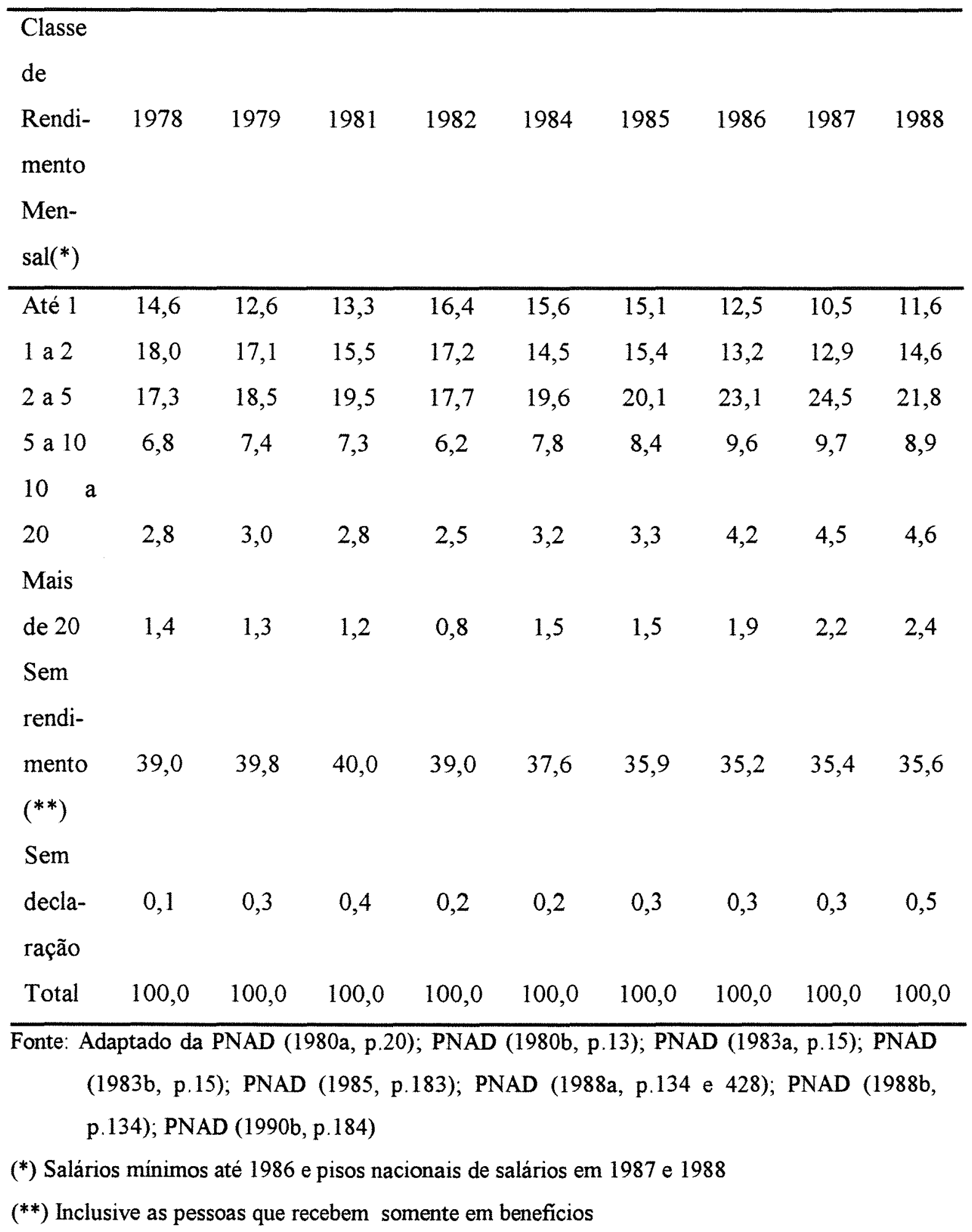


Tabela 14: Proporção de famílias por número de pessoas ocupadas (exclusive pensionistas, empregados domésticos e parentes dos empregados domésticos), 1981/90 - Brasil.

\begin{tabular}{llllllllll}
\hline & 1981 & 1983 & 1984 & 1985 & 1986 & 1987 & 1988 & 1989 & 1990 \\
\hline 1 pessoa & 47,1 & 46,1 & 46,5 & 45,2 & 44,8 & 44,2 & 43,8 & 43,3 & 43,2 \\
2 pessoas & 24,9 & 26,2 & 26,0 & 27,1 & 27,7 & 28,5 & 28,8 & 29,0 & 29,1 \\
3 ou + & 17,0 & 16,2 & 15,9 & 17,0 & 17,2 & 16,9 & 16,7 & 16,7 & 16,3 \\
\hline
\end{tabular}

Fonte: Adaptado da PNAD (1990a, p.50); PNAD (1993, p. 63)

Os dados apresentados na Tabela 14, também confirmam a existência de uma tendência de maior número de indivíduos trabalhando, por unidade familiar, no Brasil. Isto também poderá levar a modificações no mercado de alimentos no Brasil, devido a aumento da renda por unidade familiar.

De acordo com estes dados, pode-se concluir, com algumas ressalvas, que também houve um pequeno aumento da renda, tanto a nível individual como por unidade familiar, no Brasil, o que causaria mudanças no mercado de alimentos. Isto seria de suma importância no caso de frutas, que apresentam altos índices de elasticidade-renda, de acordo com dados do Programa de Apoio à Produção e Exportação de Frutas - FRUPEX (1992).

Em relação ao número de habitantes por residência, também são apresentados dados na PNAD, relatando o número médio de pessoas por família (Tabela 15) e a distribuição das famílias por número de componentes (Tabela 16), para o Brasil.

Tabela 15: Número médio de pessoas por familia, 1981/90 - Brasil

\begin{tabular}{lccccccccc}
\hline & 1981 & 1983 & 1984 & 1985 & 1986 & 1987 & 1988 & 1989 & 1990 \\
\hline Média & 4,3 & 4,2 & 4,1 & 4,1 & 4,1 & 4,0 & 4,0 & 3,9 & 3,9 \\
\hline
\end{tabular}

Fonte: Adaptado da PNAD (1990a, p.50); PNAD (1993, p. 63) 
Tabela 16: Distribuição das famílias por número de componentes (em porcentagem), 1981/90 - Brasil.

\begin{tabular}{|c|c|c|c|c|c|c|c|c|c|}
\hline & 1981 & 1983 & 1984 & 1985 & 1986 & 1987 & 1988 & 1989 & 1990 \\
\hline $\begin{array}{lll}1 & \mathrm{e} & 2 \\
\text { pessoas }\end{array}$ & 22,6 & 23,7 & 24,8 & 24,6 & 24,3 & 24,9 & 25,0 & 25,8 & 25,7 \\
\hline $\begin{array}{lll}3 & \mathrm{e} & 4 \\
\text { pessoas }\end{array}$ & 38,5 & 39,3 & 39,5 & 40,1 & 40,6 & 41,1 & 41,8 & 42,1 & 42,4 \\
\hline $\begin{array}{lll}5 & \text { e } & 6 \\
\text { pessoas }\end{array}$ & 23,2 & 23,1 & 22,9 & 23,0 & 23,2 & 23,0 & 23,0 & 22,5 & 24,1 \\
\hline $\begin{array}{l}7 \text { pessoas } \\
\text { ou mais }\end{array}$ & 15,7 & 13,9 & 12,8 & 12,3 & 11,9 & 11,0 & 10,2 & 9,6 & 7,8 \\
\hline Total & 100 & 100 & 100 & 100 & 100 & 100 & 100 & 100 & 100 \\
\hline
\end{tabular}

Fonte: Adaptado da PNAD (1990a, p. 50); PNAD (1993, p. 63)

Os dados apresentados sugerem que também houve uma tendência de diminuição no número de indivíduos por família, assim como um aumento do número de pessoas vivendo sozinhas. Estes fatos também podem causar modificações no mercado de alimentos brasileiro.

Uma conseqüência da mudança na estrutura da população, nos EUA, é a procura por conveniência, conforme ressaltado por Manchester (1992). A procura por conveniência acarretou em mudanças no mercado de alimentos, tais como: boom dos supermercados, diversificação do tipo de supermercados, aumento no número de refeições fora de casa, principalmente no setor de fast food, conforme apresentado na Tabela 11.

Em relação a estas conseqüências, no caso brasileiro, dados apresentados por Araújo et al. (1991, p. 150), afirmam que, em 1970, o setor tradicional de comércio respondia por $70 \%$ e os supermercados por $30 \%$ do volume de venda de alimentos. Estes 
autores afirmam ainda que, atualmente, os supermercados, com $14 \%$ dos pontos de venda, já possuem uma participação de mercado (market-share) próximo de $80 \%$.

Em relação à alimentação fora de casa, pesquisa desenvolvida pela Feedback Serviços de Pesquisa (1991), demonstra que, no Brasil, apenas um quinto dos indivíduos que almoçam o fazem fora de casa. Neste grupo tem-se a predominância de indivíduos do sexo masculino de grandes centros urbanos. A preferência por fast food, de acordo com esta pesquisa, atinge apenas $4 \%$ da população.

\subsubsection{Influências internas}

Conforme destacado anteriormente, no modelo de Schiffman \& Kanuk (1994), o campo psicológico, dentro do componente processo, representa as influências internas que afetam o processo de tomada de decisão pelo consumidor.

Estes autores salientam ainda outros dois conceitos chave, incluídos no campo psicológico, que atuam em função das percepções do consumidor. São eles: risco percebido e conjunto evocado.

O risco percebido é definido como "incerteza que os consumidores enfrentam quando não podem prever as conseqüências de suas decisões de compra" (Schiffman \& Kanuk, 1994, p. 562). É importante salientar que os consumidores são influenciados apenas pelo risco que eles percebem, independentemente da existência ou não do risco. Risco não percebido, não importa o quão real ou perigoso seja, não influencia o comportamento do consumidor.

Analisando o fator risco percebido, em relação ao consumo de alimentos em geral, existe uma crescente preocupação com riscos à saúde causados pela presença de contaminações ou produtos químicos nos alimentos ingeridos. Também há uma 
preocupação crescente em relação à ingestão de alimentos saudáveis. Prova disto se dá pelo fato de vários autores mencionarem, quando se discute o consumo de alimentos, a preocupação com alimentação saudável, não prejudicial à saúde, como será visto a seguir.

Manchester (1992, p. 91 e 92) comenta que, desde a década de 70, os norte americanos começaram a ter preocupações com a saúde na escolha de alimentos. $O$ assunto preocupação com a saúde, ainda segundo o autor, tem sido alvo de notícias constantes, além disso, também verifica-se a preocupação e esforços privados e governamentais no sentido de incrementar a educação da população, em relação à escolha de alimentos.

Esta proliferação de informação, ainda de acordo com o referido autor, tem tido o efeito, muitas vezes perverso, de separar os alimentos em "ruins" e "bons" na mente dos consumidores. Esta separação é feita com base em atributos como teor de gordura, teor de fibras entre outros fatores. No entanto, nutricionistas e agências do governo norte americano não aprovam esta tendência de separação dos alimentos nestas duas categorias ("bons" e "ruins"), pois esta atitude nem sempre corresponde à realidade.

A respeito desta percepção de qualidade, em relação a produtos "saudáveis", Wheelock (1992), apresenta um artigo bastante interessante, no qual ressalta a possibilidade de pagamento de um "prêmio" por qualidade, por parte do consumidor inglês. Neste sentido, ele apresenta os conceitos de qualidade real e pseudo-qualidade, melhor detalhados na Tabela 17, afirmando que, atualmente, os consumidores, na Inglaterra, estão cada vez mais bem informados sobre as características adequadas dos produtos, exigindo cada vez mais atributos de qualidade real.

No entanto, para o consumidor ter conhecimento do que realmente constitui uma alimentação "saudável", baseada em produtos de qualidade real, ele deve ser informado adequadamente sobre os atributos que implicam em uma qualidade real do 
produto. Darrall (1992) menciona, em relação à informação aos consumidores sobre características adequadas dos produtos, que o governo britânico deveria se responsabilizar por pesquisas e informações confiáveis sobre alimentação não prejudicial à saúde, divulgando-as para a população.

Tabela 17: Exemplos de atributos que implicam em qualidade real e em pseudo qualidade.

\begin{tabular}{ll}
\hline \multicolumn{1}{c}{ Qualidade real } & \multicolumn{1}{c}{ Pseudo qualidade } \\
\hline (1) Seleção de ingredientes & (1) Uso do termo "natural" - aditivos \\
(2) Método de distribuição - ex.: uso de & "naturais" também podem ser tóxicos/ \\
distribuição refrigerada & alimentos sem preservativos também \\
(3) Nutrição - ex.: óleos polinsaturados & podem ser perigosos \\
(canola, girassol, etc.) & (2) Apelos nutricionais não sérios \\
(4) Vida de prateleira - procedimento mais & (3) Embalagem do produto - semelhante \\
cuidadosos para garantir vida de prateleira & a outros produtos \\
mais longa & (4) Apelos a saúde não sérios \\
\hline
\end{tabular}

Fonte: Adaptado de Wheelock (1992, p. 41)

Cannon (1992) também menciona a atual atitude das empresas inglesas em relação à tendência de alimentação saudável. Segundo ele, elas estão adotando medidas paliativas, como enfatizar os aspectos positivos de seus produtos, mudança de embalagem ou introdução de novas formulações. No entanto, no longo prazo, o consumidor vai procurar por produtos com diferenciação real.

Darrall (1992) apresenta um estudo sobre estas novas preocupações e suas influências em toda cadeia produtiva, em relação ao setor alimentar. $\mathrm{O}$ resultado de sua pesquisa foi que o grau de conhecimento, a respeito de estudos sobre alimentação saudável, varia de acordo com o estágio em que o indivíduo se encontra na cadeia e também com o setor produtivo estudado. De maneira geral, os varejistas tinham maior grau de conhecimento, seguidos pelas indústrias e, finalmente, pelos produtores. Neste 
aspecto o autor conclui que a informação captada junto aos consumidores se dispersa na cadeia produtiva. Também conclui-se no estudo que, para maior envolvimento dos produtores no processo, deverá haver apoio governamental, pois a mudança tem custo elevado e envolve pesquisa.

Grunet \& Kristensen (1990), ainda em relação aos hábitos alimentares, apresentam o surgimento do consumidor ecologicamente consciente na Europa. $O$ consumidor ecologicamente consciente é definido, neste estudo, como "um indivíduo que tem conhecimento dos custos externos da produção, distribuição e uso de produtos convencionais, os avalia negativamente, e tenta minimizá-los através de seu comportamento" (Balderjahn ${ }^{26}$, citado em Grunet \& Kristensen, 1990, p. 3). Este consumidor tende a direcionar seu consumo para alimentos organicamente produzidos. No entanto, mesmo na Europa, este é um grupo ainda em surgimento, o que pode ser comprovado por dados apresentados em Grunet (1992), referentes a estudo realizado na Dinamarca, como pode ser observado na Tabela 18.

Ao analisar-se os dados da Tabela 18, pode-se perceber que a porcentagem da população que se enquadra como consumidora habitual deste tipo de produto é realmente muito reduzida, variando de $0,2 \%$, no caso do pão, até $3,3 \%$ da população, para vegetais. Uma porcentagem maior de indivíduos consome ocasionalmente este tipo de produto, variando de $1,4 \%$ da população, para cereais, até $19,2 \%$ para os vegetais selecionados. Essa situação, tanto de compra ocasional, como de compra habitual, sugere um mercado que se inicia e com enorme potencial de crescimento.

Para finalizar o estudo do consumidor ecologicamente consciente e sua importância no mercado dinamarquês, o autor ainda apresenta a participação de mercado de alguns dos produtos, produzidos organicamente, estudados. Neste caso, a participação

\footnotetext{
${ }^{26}$ BALDERJAHN, I. Strukturen sozialen Konsumbewusstseins. Reanalyse und Versuch einer Bestimmung. Marketing ZFP, 7(4). 1985. pp. 253-262.
} 
de mercado varia de $0,04 \%$, para carne suína, até $1,8 \%$, para vegetais. Isto vem a comprovar a pequena participação deste tipo de produto no consumo, mesmo em um país desenvolvido como a Dinamarca.

Tabela 18: Consumidores de produtos organicamente produzidos, na Dinamarca, em porcentagem.

\begin{tabular}{lccc}
\hline Grupos de produtos & $\begin{array}{r}\text { Compradores } \\
\text { habituais }\end{array}$ & $\begin{array}{c}\text { Compradores } \\
\text { ocasionais }\end{array}$ & $\begin{array}{c}\text { Participação no } \\
\text { mercado }\end{array}$ \\
\hline Leite & 1,9 & 7,5 & 1,5 \\
Manteiga, queijo & 0,5 & 2,3 & $0,04^{\mathrm{a}} \quad 0,18^{\mathrm{b}}$ \\
Carne & 0,5 & 3,3 & 0,14 \\
Ovo & 0,6 & 4,3 & 0,08 \\
Pão & 0,2 & 1,9 & 1,8 \\
Cereais & 0,4 & 1,4 & \\
Vegetais (batatas, & & 19,2 & \\
cenouras e cebolas) & 3,3 & 2,8 & \\
Frutas & 0,4 & & \\
\hline
\end{tabular}

a: carne suína

b: carne bovina

Fonte: Grunet (1992, p.7)

Seibel (1990) apresenta, por outro lado, em seu trabalho, a preocupação do governo alemão com gastos devido à alimentação incorreta por parte da população. Em 1988 , de acordo com o relatório da alimentação, foram gastos $27 \%$ do custo total com doenças da República Federal Alemã, com custos diretos e indiretos decorrentes da escolha errada por alimentos. Esse autor apresenta também o que seria um alimento saudável no contexto alemão. Um alimento saudável deve ser inofensivo à saúde, ter alto valor qualitativo e preço vantajoso (relação preço/ qualidade). Outro conceito que vem aparecendo em pequeno, mas crescente, grupo de consumidores alemães, em 
concordância com Grunet (1992), é a produção favorável ao meio ambiente. Neste sentido o autor apresenta os produtos oriundos de cultivo ecológico e os produtos advindos de cultivo controlado.

Os produtos oriundos de cultivo ecológico são aqueles nos quais os componentes se originam $95 \%$ de cultivo ecológico (sem produtos e adubos químicos) e apenas $5 \%$ de cultivo convencional. Estes produtos são controlados pela AGÖL (Associação dos Trabalhadores para o Cultivo Ecológico). Os problemas apresentados por pesquisas que estudam o consumo deste tipo de produto são relativos à ausência de confiança na veracidade das informações prestadas pelos fabricantes e às dificuldades de aquisição destes produtos, devido a poucos locais de compra, aumentando o tempo envolvido na aquisição deste tipo de produto. Já os produtos advindos do plantio controlado são aqueles cujo cultivo foi realizado com limitação dos produtos químicos e adubos nitrogenados, em níveis não muito danosos ao ambiente. Esse trabalho também demonstra a presença de preocupações com a saúde no contexto alemão, inclusive por parte do governo alemão.

Barkema (1993) também apresenta a preocupação do consumidor americano com doenças do coração e câncer, salientando, como conseqüência, o aumento do consumo de frutas e vegetais frescos e diminuição do consumo de produtos ricos em gorduras, como leite integral e carne vermelha. Estas tendências de alimentação também já haviam sido detectadas anteriormente por Manchester (1992).

No caso brasileiro, é difícil perceber mudanças no consumo de alimentos causadas por preocupações deste tipo, pois os dados disponíveis de consumo per capita, a nível global - ENDEF (1978) e POF (1991) - são tabulados de maneira desigual, dificultando comparações efetivas. Embora a comparação seja dificultada a partir dessas fontes, pesquisa realizada pela Feedback Serviços de Pesquisa (1991) mostra que, quando questionado a respeito do assunto, o brasileiro diz se preocupar com colesterol, fibras, 
resíduos químicos e alimentação saudável em geral. Porém, em teste realizado nesta mesma pesquisa, há evidências que o consumidor brasileiro não tem ainda muito conhecimento dos papéis e das implicações destes componentes na sua alimentação.

Megido \& Xavier (1993) apresentam também pesquisa realizada pela empresa Negócios \& Mercado, para a Agroceres, tradicional empresa do setor de sementes, em São Paulo, onde são destacados atributos valorizados pelo consumidor em relação a produtos alimentares (Figura 10).

Estes dados também confirmam uma possível preocupação do consumidor brasileiro com a alimentação saudável.

No entanto, quando comparamos o consumidor brasileiro com o consumidor de países mais desenvolvidos, temos que levar em conta seus níveis de educação e renda inferiores, que implicam em falta de conscientização/ conhecimento e impossibilidade de optar por alimentos mais saudáveis que possuam preço superior.

Embora existam estas dificuldades devido ao nível de educação e baixo poder aquisitivo do consumidor brasileiro, já existem casos isolados de consumo de alimentos produzidos organicamente. Organizações não-governamentais como a Conatura (RJ), AECIA (no sul do país) e Associação de Agricultura Orgânica - AAO (SP) têm feito esforços no sentido de promover o cultivo e comercializar produtos orgânicos, de acordo com contato feito com o Sr. Luiz Geraldo ${ }^{27}$, engenheiro agrônomo da AAO.

A AAO foi criada em maio de 1989 e conta, atualmente, com aproximadamente 1300 associados, entre produtores rurais, cientistas e técnicos ligados à produção, além

${ }^{27}$ GERALDO, L. (AAO - Associação de Agricultura Orgânica). Comunicação pessoal a essa autora em 1995. 
de profissionais das áreas de saúde, ensino, publicidade, jornalismo, entre outros, conforme indica folheto distribuido por esta associação ${ }^{28}$.

\section{Atributos Citados}

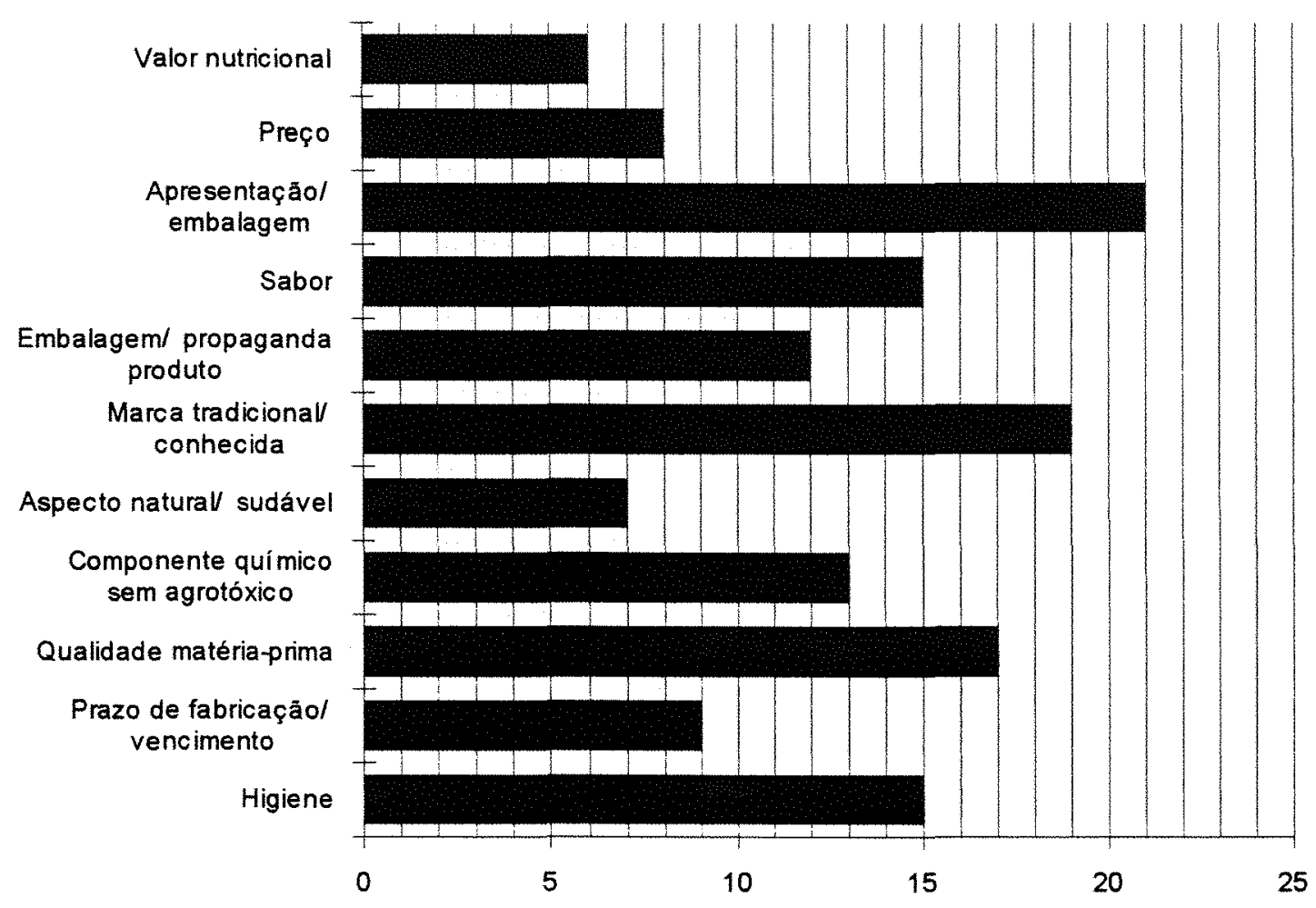

Figura 10: O que o consumidor mais valoriza em produto alimentar industrializado? (espontâneo) - em porcentagem do total da amostra.

Fonte: Megido \& Xavier (1993, p.155)

Esta associação oferece cursos, fomenta e fiscaliza a produção, divulga e comercializa produtos orgânicos. A comercialização é feita através de "feiras do produtor orgânico". De acordo com o engenheiro agrônomo desta associação, Sr. Luiz Geraldo, atualmente, em São Paulo, este mercado movimenta aproximadamente US\$ 1,5 milhão/ ano.

${ }^{28}$ ASSOCIAÇÃO DE AGRICULTURA ORGÂNICA - AAO. Folheto de Divulgação. 
Riscos à saúde que podem ser causados por alimentos, de acordo com Manchester (1992), estão relacionados à contaminação microbiana e resíduos de pesticidas (segurança alimentar). A contaminação microbiana pode se desenvolver com maior intensidade em alimentos semi-preparados, conseqüentemente o cuidado das indústrias com o processo de produção deste tipo de alimento deve se intensificar.

A preocupação com ingestão de pesticidas também tem se intensificado nos EUA, tanto no consumo de alimentos in natura, como de produtos processados, ainda de acordo com Manchester (1992). Respondendo a este novo temor dos consumidores, muitos estabelecimentos, como ressalta esse pesquisador, têm feito testes com seus produtos antes de ofertá-los. O oferecimento de produtos orgânicos, já discutido anteriormente, também tem lugar neste cenário, embora seu preço seja mais elevado.

Byrne \& Toensmeyer (1993), em estudo sobre atitudes dos consumidores a respeito de segurança alimentar e produtos in natura, conduzido em uma região específica dos EUA, concluíram, em relação à presença de produtos químicos nos alimentos, que resíduos de pesticidas são considerados como a maior fonte de preocupação, por parte dos consumidores, quando se menciona segurança alimentar, o que vem a demonstrar a importância deste item.

Weersink et al. (1990), em estudo piloto sobre atitudes e percepções dos consumidores em relação a aspectos nutricionais, realizado em Guelph, Ontario, Canadá, em março de 1990, também ressaltam que os consumidores estão mais preocupados a respeito de doenças do coração, câncer, contaminantes e aditivos químicos, confirmando pontos apresentados anteriormente.

Em relação a danos à saúde causados por alimentos (segurança alimentar), o consumidor norte-americano tem seus direitos assegurados pelo "The Consumer Bill of Rights" (carta de direito dos consumidores), apresentados por Engel et al. (1993). No 
primeiro, dentre os seis direitos apresentados por esta carta, tem-se: "Direito à segurança: proteção contra produtos ou serviços que são perigosos à saúde e à vida" (p. 820).

No caso brasileiro, o Código do Consumidor (Direitos do Consumidor, 1991) também garante o direito à segurança alimentar, através do capítulo IV, seção I, artigo $8^{\circ}$, reproduzido a seguir: Art. $8^{\circ}$ : "Os produtos e serviços colocados no mercado de consumo não acarretarão riscos à saúde ou segurança dos consumidores, exceto os considerados normais e previsiveis em decorrência de sua natureza e fruição, obrigandose os fornecedores, em qualquer hipótese, a dar informações necessárias e adequadas a respeito" (p. 15).

As tendências apresentadas, em relação ao consumo de alimentos e a preocupação com riscos à saúde, indicam a possibilidade de um maior consumo de produtos vegetais, entre eles as frutas, principalmente as que não contiverem produtos danosos a saúde, como pesticidas, por exemplo. Prova desta tendência está em estudo recente da agência britânica Mintel (Superhiper, 1994a, p. 108), no qual menciona-se que as preocupações com a saúde e o meio ambiente foram responsáveis por uma explosão nas vendas de alimentos vegetarianos e orgânicos, na Inglaterra, tendo estes últimos crescido quase cinco vezes em vendas, de 21,5 milhões em 1988 para 105,1 milhões de libras em 1993

Em relação ao conjunto evocado, pode-se mencionar alguns dados da POF (1991), já citados anteriormente, que podem vir a fornecer alguns indícios sobre o tema. Segundo esta pesquisa, $14,2 \%$ das despesas com frutas correspondem ao item banana, $23,4 \%$ ao item laranja, $14,2 \%$ ao item maçã e $48,2 \%$ a outras frutas. Através destes valores pode-se perceber a importância destes três tipos de frutas (banana, laranja e maçã) no consumo, pois somente estas frutas representam $51,8 \%$ das despesas (com consumo de frutas). A ausência de informações sobre este item acentua a importância do estudo exploratório. 


\subsubsection{Processo de tomada de decisão}

O processo de tomada de decisão, conforme apresentado por Schiffman \& Kanuk (1994), está dividido em: reconhecimento do problema, busca de informação e avaliação das alternativas. Para facilitar a apresentação do assunto, para o caso específico de frutas, este item será dividido em três partes, cada uma correspondendo a uma fase do processo.

\subsection{Reconhecimento do problema}

O reconhecimento do problema, em relação ao item frutas, está relacionado, neste estudo, às frutas a serem compradas de acordo com o uso que terão (consumidas in natura, usadas como ingrediente para preparo de determinados pratos ou sucos). Assim sendo, dependendo do uso final do produto, se dará a opção pelo tipo de fruta a ser adquirido

Para exemplificar, pode-se citar a necessidade de um indivíduo em relação ao consumo de um suco. Neste caso, será feita uma opção por frutas adequadas ao consumo na forma de suco, como laranja, caju, acerola, entre outras. No caso de necessidade de uma fruta para ser consumida in natura, a opção pode ser por outros tipos de frutas. $O$ mesmo pode ocorrer no caso do consumidor desejar uma fruta para ser usada como ingrediente de um doce.

Resumindo, tem-se, neste contexto, uma relação entre uso desejado, de acordo com a necessidade a ser satisfeita, e tipo de produto a ser adquirido. Infelizmente, não foi encontrado, na revisão de literatura, tanto a nível local como internacional, um estudo que mencionasse, especificamente, esta relação para o caso de frutas. Assim sendo, a importância do estudo exploratório se acentua em relação a este item. 


\subsection{Busca de informação}

Em relação à busca de informações, conforme observado anteriormente, em Schiffman \& Kanuk (1994), o consumidor inicia sua busca por informação na própria memória, só depois procura por fontes externas de informação a respeito de determinado produto. A experiência passada é considerada também como fonte interna de informação por Schiffman \& Kanuk (1994). Quanto mais experiência passada, menor quantidade de informação externa será necessária para que uma decisão seja tomada. No entanto, de maneira geral, a maioria das decisões dos consumidores está baseada em uma combinação de experiência passada (fontes internas) e apelos de marketing e informações não comerciais (fontes externas).

No caso específico de alimentos, entre os quais tem-se as frutas, Weersink et al. (1990), em seu estudo piloto sobre atitudes e percepções nutricionais dos consumidores, realizado em Guelph, Ontario, Canadá, descobriram que as fontes primárias não comerciais de informação são consideradas como mais confiáveis pelos consumidores. Em segundo lugar, tem-se as fontes secundárias não comerciais e, em terceiro lugar, consideradas como menos confiáveis, tem-se as fontes comerciais.

Os tipos de fonte de informação de acordo com as categorias em que estão incluídos, de acordo com estes autores, estão apresentados na Tabela 19.

Ainda em relação à fonte de informação, Byrne \& Toensmeyer (1993, p. 92), mencionam que informações sobre segurança alimentar provenientes da comunidade acadêmica têm maior probabilidade de aceitação por parte dos consumidores, de acordo com pesquisa realizada em região específica dos EUA.

Vale ainda ressaltar que o risco percebido também pode influenciar este estágio do processo de decisão, como mencionado anteriormente por Schiffman \& Kanuk 
(1994). Em situação de alto risco percebido, os consumidores se engajarão mais arduamente em busca e avaliação da informação; já em situações de baixo risco percebido, eles podem optar por táticas mais simples de coleta e avaliação da informação.

Tabela 19: Tipos de fontes de informação nutricional por categoria

\begin{tabular}{|c|c|c|}
\hline Comerciais & Primárias não comerciais & Secundárias não comerciais \\
\hline$\checkmark$ revistas & $\checkmark$ médico da família & $\checkmark$ artigos de revistas \\
\hline$\checkmark$ propagandas em jornais & $\checkmark$ nutricionista & $\checkmark$ artigos de jornal \\
\hline$\checkmark$ propagandas no rádio & $\checkmark$ rótulos controlados pelo & $\checkmark$ comentários no rádio \\
\hline$\checkmark$ propagandas na TV & governo & $\checkmark$ programas de TV \\
\hline$\checkmark$ propagandas em centros & $\checkmark$ livros & $\checkmark$ amigos e familia \\
\hline de dieta & & $\checkmark$ escolas \\
\hline
\end{tabular}

Fonte: Weersink et al. (1990, p. 12)

\subsection{Avaliação das alternativas}

$\mathrm{Na}$ avaliação das alternativas, independentemente do tipo de regra de decisão a ser tomado pelo consumidor, a importância dos atributos de determinado produto é indiscutível.

No caso específico de frutas, foram encontrados alguns estudos a respeito de atributos importantes para escolha de alimentos, apresentados a seguir.

Conforme mencionado anteriormente, Megido \& Xavier (1993) apresentam pesquisa realizada pela empresa Negócios \& Mercado, para a Agroceres, em São Paulo, onde são destacados atributos valorizados pelo consumidor em relação a produtos alimentares industrializados (Figura 10). 
Byrne \& Toensmeyer (1993) também apresentam os atributos, por ordem de importância, nas decisões de aquisição de alimentos, para uma região específica dos EUA, onde foi realizado o estudo destes autores (Figura 11).

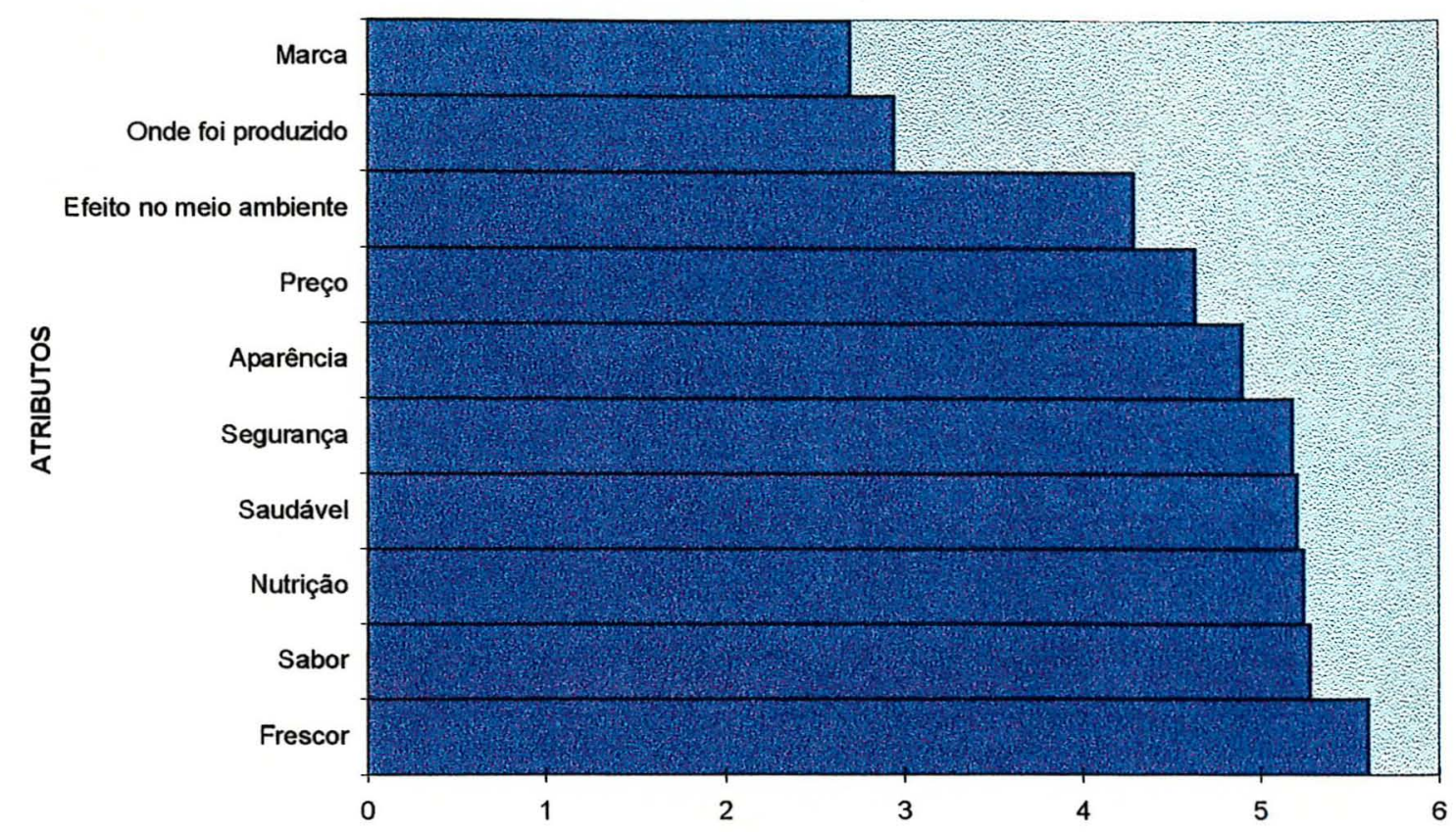

Figura 11: Atributos, por ordem de importância, nas decisões de compra de alimentos (quanto maior o valor, maior a importância do atributo).

Fonte: Adaptado de Byrne \& Toensmeyer (1993, p.46)

Von Alvensleben \& Meier (1990) também apresentam alguns critérios considerados importantes na aquisição de frutas e vegetais. A Tabela 20 mostra os atributos mencionados, assim como a freqüência de resposta, em porcentagem, em pesquisa realizada na Alemanha.

Como pode-se observar, nesta pesquisa, a maioria dos consumidores julga os produtos pela sua aparência. Mais de $60 \%$ dos indivíduos pesquisados se preocupa com o frescor dos produtos, propriedade que provavelmente está ligada à aparência. Considerando ainda os consumidores pesquisados, $56 \%$ consideram a presença de um 
selo de qualidade como um critério de escolha a ser considerado. Finalmente, segundo estes autores, de acordo com a pesquisa apresentada, pode-se considerar que, em geral, a qualidade externa de um produto é a principal informação sobre o mesmo, aos olhos dos consumidores

Tabela 20: Critérios principais na aquisição de frutas e verduras e frequeências mencionadas, em porcentagem.

\begin{tabular}{|c|c|}
\hline Critério & Frequêencias \\
\hline Aparência & 76 \\
\hline Frescor & 66 \\
\hline Selo de qualidade & 56 \\
\hline Preço & 52 \\
\hline Firmeza & 41 \\
\hline Cor & 34 \\
\hline Variedade & 30 \\
\hline Classe & 17 \\
\hline Tamanho & 14 \\
\hline
\end{tabular}

Fonte: CMA/GFK in Von Alvensleben \& Meier (1990, p. 154)

Embora apresentem resultados diferentes, os estudos apresentados demonstram que existem uma série de atributos, a serem considerados pelos consumidores, na ocasião de aquisição de determinado produto. Estes atributos também têm importância diferenciada na percepção dos consumidores.

\subsubsection{Compra}

Conforme ressaltado anteriormente por Schiffman \& Kanuk (1994), existem dois tipos de comportamentos de compra: compras experimentais/testes ou compras repetidas. Quando compra-se uma quantidade menor que a habitual de determinado 
produto (ou marca), pela primeira vez, pode-se considerar esta compra como um teste. Portanto, este teste seria uma fase exploratória do comportamento de compra, na qual o consumidor deseja avaliar o produto através de seu uso direto. Este tipo de comportamento pode ocorrer com o item frutas.

$\mathrm{Na}$ compra repetida, em contrapartida, o consumidor adquire um produto (ou marca) conhecido.

Quando discute-se a compra de determinado produto, um fator importante a ser considerado é a situação onde ocorre a compra. A situação de compra pode ser composta por vários elementos. Entre eles destacam-se: ambiente de informação, ambiente do ponto de venda e influência temporal.

O ambiente de informação, mencionado por Engel et al. (1993), em relação ao item frutas, seria importante, principalmente em relação a frutas novas colocadas no mercado. Neste contexto, as características ambientais, como: disponibilidade de informação, carga de informação, formato e forma da informação, devem ser estudadas, uma vez que influenciarão o consumo.

Como exemplo, Smith, em entrevista citada em Bennett (1994e), menciona que, para produtos não conhecidos serem adquiridos por consumidores que desejam experimentar novos itens, deve haver o fornecimento de informações a respeito de como preparar e comer estes produtos. Johnson, em entrevista citada em Bennett (1994e), também ressalta a importância deste tipo de informação, fazendo inclusive demonstrações de como preparar certos itens não conhecidos pelo público em geral, em certos pontos de venda, com os produtos comercializados por sua empresa. A empresa também fornece folhetos explicativos aos consumidores. Sem este tipo de informação, o produto provavelmente não seria adquirido pelo consumidor, ou poderiam ocorrer insatisfações 
decorrentes do consumo inadequado do produto, devido ao não conhecimento do modo de preparo.

O ambiente do ponto de venda, ou atmosfera de loja, também pode influenciar o consumo de frutas. Neste aspecto, os elementos situacionais apresentados por Engel et al. (1993), tais como: música ambiente, layout da loja, cores utilizadas, materiais de ponto de venda (displays, por exemplo), presença de vendedores e lotação do ponto de venda, vão influenciar o consumo. No caso específico de frutas, conforme mencionado anteriormente, outros elementos, tais como limpeza e reposição de produtos estragados (muito freqüentes, por se tratar de produto perecivel e sensível ao manuseio), também apareceriam como itens importantes.

A influência temporal, conforme destacado anteriormente, de acordo Engel et al. (1993), representa um aspecto importante dos componentes situacionais, principalmente em relação às situações de compra. Isto também se aplicaria em relação ao comportamento de consumo de frutas. Neste sentido, as dimensões apresentadas pelos autores, tais como: época do ano/ sazonalidade, tempo disponível para a compra (pressões temporais), e tempo em relação a eventos anteriores (exemplo: indivíduos compram maior quantidade de alimentos quando estão com fome), exerceriam influência sobre o comportamento de consumo de frutas.

No entanto, é interessante dar um maior destaque ao aspecto sazonal no consumo de frutas, uma vez que as frutas, quando tomadas isoladamente, apresentam sazonalidade de produção, o que irá interferir de forma acentuada no consumo.

Um exemplo da influência sazonal no consumo de frutas, pode ser dado através da participação de cada fruta no gasto total com este item, considerado constante no decorrer do ano (Figura 12). 


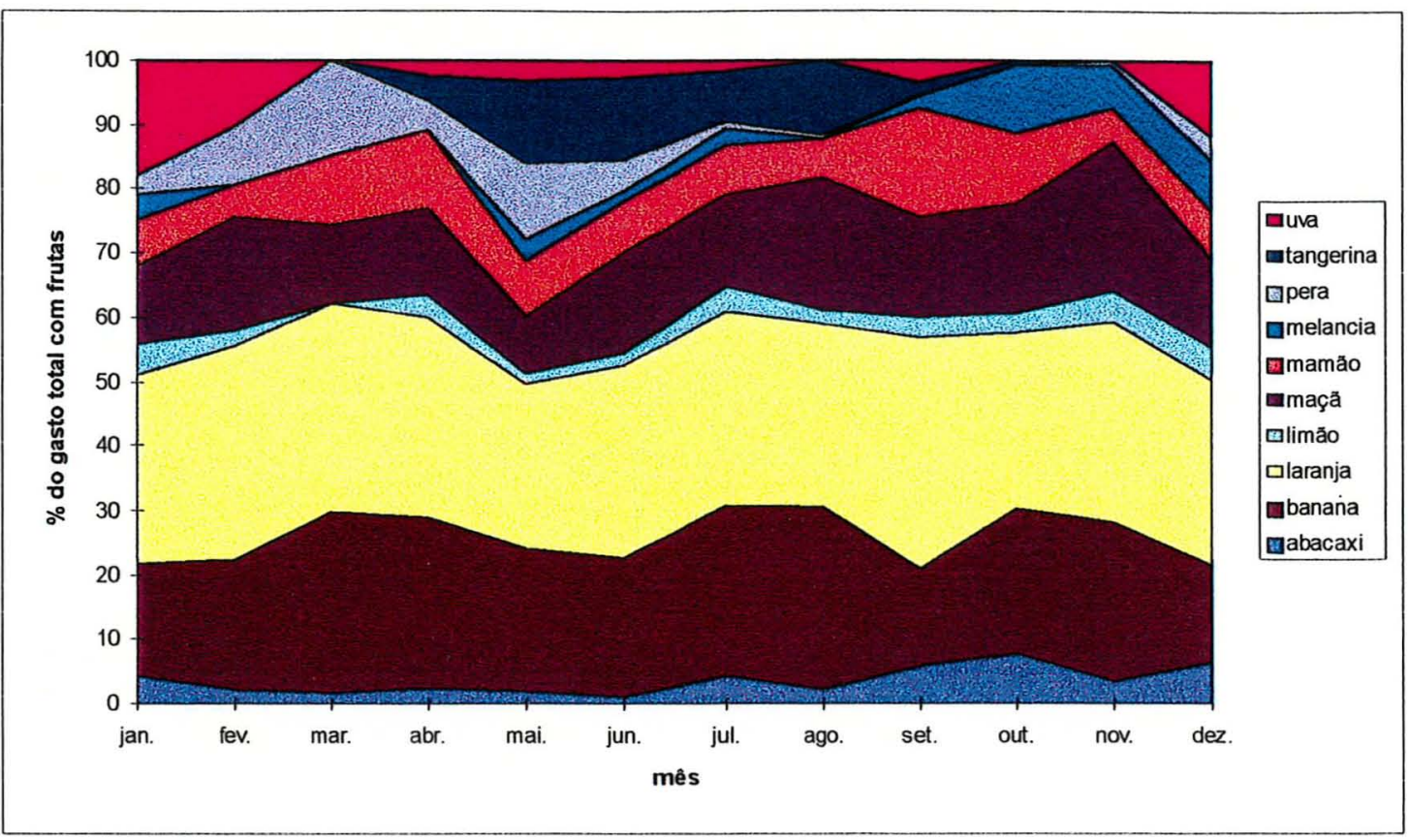

Figura 12: Participação de cada fruta no gasto total - Famílias com recebimentos de 1 a 40 pisos salariais - Região Metropolitana de São Paulo.

Fonte: POF (1991, p. 208)

Estes dados representam a soma dos efeitos dos vários componentes relacionados ao item influência sazonal no consumo, tais como: preço, quantidade disponível para consumo, tipo de fruto preferido de acordo com a estação, etc. Infelizmente, a maneira como estes dados são apresentados na POF (1991), ou seja, apresenta-se apenas a variação dos gastos com cada item, considerando-se um gasto constante com o produto (frutas) no decorrer do ano, não permite o isolamento dos efeitos dos diversos componentes sazonais existentes.

Apesar da dificuldade de isolamento dos efeitos dos diferentes componentes sazonais, pode-se fazer algumas suposições a respeito desta figura. Por exemplo, os gastos com certos tipos de frutas (uva, tangerina, pêra, melancia) se concentram em determinadas épocas do ano, sugerindo que a disponibilidade destes tipos de produto é restrita em algumas destas épocas. Outro exemplo interessante, que pode ser deduzido 
destes dados, consiste no fato de que, mesmo os produtos disponíveis o ano todo (laranja, banana, por exemplo), possuem períodos de entressafra, quando seu preço aumenta. Como os gastos com estes produtos, de maneira geral, permanecem constantes, pode-se concluir que o consumo no período de entressafra (preços maiores) se reduz.

Outro fator importante, quando menciona-se a aquisição de frutas, está relacionado com o local de compra do produto.

Os locais de compra do produto, ainda segundo a POF (1991), são colocados na seguinte ordem decrescente de importância: feiras, supermercados, armazéns, mercados, estabelecimentos especializados e vendedores ambulantes. O levantamento mais antigo do IBGE (ENDEF, 1978) também apresenta seqüência semelhante (feiras - 58,6\%; supermercados - 14,7\%; vendedores ambulantes - 11,4\%; armazéns - 8,1\%; estabelecimentos especializados $-7,4 \%$ ).

No entanto, essa ordem de preferência vem sofrendo mudanças. Atualmente, os consumidores têm procurado os supermercados para se abastecerem de alimentos, inclusive de frutas. Infelizmente não foram encontrados dados estatísticos recentes para comprovar essa tendência, embora Araújo et al. (1991) tenham afirmado que $80 \%$ do volume de alimentos consumidos são adquiridos em supermercados, o que corresponderia a apenas $14 \%$ dos pontos de venda.

Pesquisa conduzida pela Nielsen Serviços de Marketing (O Novo Perfil do Consumidor, 1992), realizada entre 15 de julho e 10 de agosto de 1992 em áreas representativas de todo o Brasil, apresenta, também dados sobre a importância dos supermercados como pontos de venda de produtos de consumo. Foram entrevistadas 1440 pessoas em 39 cidades de nove estados, escolhidas de acordo com sua representatividade no faturamento do setor de supermercados. 
Segundo esta pesquisa $100 \%$ dos consumidores fazem compras em supermercados (Tabela 21).

Tabela 21: Local de compras por porcentagem de consumidores que os utilizam

\begin{tabular}{lc}
\hline \multicolumn{1}{c}{ Local de compra } & \% dos consumidores que os utilizam \\
\hline Supermercados & 100 \\
Açougues & 61 \\
Feiras & 51 \\
Sacolões & 35 \\
Mercearias & 28 \\
Peixarias & 25 \\
Quitandas & 22 \\
Armazéns & 14 \\
Atacadistas & 8 \\
Cooperativas de consumo & 6 \\
SESI & 5 \\
\hline
\end{tabular}

Fonte: O Novo Perfil do Consumidor (1992, p. 96)

As entrevistas também mostram, no entanto, que os consumidores que fazem compras em supermercados complementam esta atividade em outros tipos de lojas do varejo de alimentos.

Ainda em relação à escolha dos locais de compra, Meulenberg \& Trijp (1991) apresentam um estudo a respeito dos fatores que conduzem a escolha do local de compra, em relação a alimentos frescos, na Holanda. No que se refere ao item frutas, um dos resultados apresentados pela pesquisa é mostrado na Tabela 22 .

Embora o consumidor holandês deva ser diferente do brasileiro, esta pesquisa confirma a expectativa de que os supermercados são procurados, principalmente, devido 
a preços vantajosos e ofertas atraentes, além da conveniência que oferecem, tendo, porém, algumas restrições quando comparados às lojas especializadas.

Tabela 22: Diferenças na percepção de características de frutas frescas supridas por supermercados e lojas especializadas (porcentagem de indivíduos que julgam cada característica aplicável para supermercados ou lojas especializadas).

\begin{tabular}{lcc}
\hline & Supermercado & Loja especializada \\
\hline Preços atraentes & 25 & 13 \\
Ofertas atraentes & 34 & 15 \\
Boa qualidade & 22 & 37 \\
Variedade ofertada & 18 & 34 \\
Produtos exclusivos & 9 & 50 \\
Serviço especializado & 10 & 56 \\
Boa qualidade do serviço & & 34 \\
(amigável) & 18 & 52 \\
Serviço especial & 11 & \\
\hline
\end{tabular}

Fonte: Meulenberg \& Trijp (1991, p. 86)

Conforme mencionado anteriormente, supõe-se, neste estudo, que a tomada de decisão em relação ao consumo de frutas seria autônoma. Desta maneira um membro da família tomaria uma decisão autônoma sobre as frutas a serem consumidas ou não, levando em conta as preferências dos outros membros. Estamos, portanto, considerando que o ator encarregado da compra tomaria a decisão de consumo.

Estes dados podem ser comprovados pela pesquisa conduzida pela Nielsen $(\mathrm{O}$ Novo Perfil do Consumidor, 1992, p. 96), mencionada anteriormente, na qual constatouse que a mulher, sozinha, ou com o marido ou outra pessoa, participa com $91 \%$ das respostas sobre quem costuma fazer as compras de supermercado. A importância da mulher ainda aumenta em relação à decisão de consumo, com uma participação de $92 \%$, 
sendo que, sozinha, ela decide o assunto em $60 \%$ dos domićlios, com o companheiro em outros $27 \%$ e com outra pessoa em $5 \%$.

\subsubsection{Pós-compra}

Conforme mencionado, é importante ressaltar que, a análise do comportamento do consumidor não deve se encerrar após a compra de determinado produto, como ressaltado no decorrer deste estudo, uma vez que a experiência com o uso de um produto ou serviço contribui para a satisfação do consumidor.

Assim sendo, o armazenamento e o preparo do produto (pré-consumo), as situações de consumo (consumo) e as sensações pós-consumo (pós-consumo), são de suma importância na análise do comportamento do consumidor. No caso específico de frutas, surge também um item importante, devendo ser considerado, que é o descarte. $O$ descarte ocorre devido à perecibilidade deste tipo de produto. Além disso, mesmo que o produto não seja descartado devido à sua alta perecibilidade, ainda tem-se que computar os residuos (casca, semente, etc.) no item descarte.

Como destacado anteriormente, segundo Engel et al. (1993), o consumo, geralmente, ocorre em um cenário diferente daquele onde o produto foi adquirido, tanto fisicamente quanto no aspecto temporal. No entanto, mesmo quando as situações de compra e uso são distintas, existe uma forte influência da situação de uso "pretendida" no decorrer do processo de tomada de decisão. Estes tipos de comportamentos continuariam válidos para o caso de frutas. Exemplificando, quando se compra frutas para consumo na residência, para diferentes situações pretendidas de uso (sobremesa para um dia de semana, sobremesa para uma ocasião especial, com convidados, ou ainda ingrediente para preparo de uma receita), provavelmente tem-se variações no processo de tomada de decisão, conforme mencionado anteriormente. 
$\mathrm{O}$ ambiente social que caracteriza uma situação de uso, poderia modificar o comportamento de consumo, também para o caso de frutas. Por exemplo, as frutas consumidas em um ambiente público poderiam ser diferentes das consumidas em casa. Desta maneira, um indivíduo pode comer uma banana ou uma tangerina, como sobremesa, em um dia comum, em sua casa, no entanto, dificilmente, consumiria este tipo de fruta em um restaurante mais sofisticado.

Conforme mencionado anteriormente, o tempo no qual o uso ocorre também pode afetar o comportamento, segundo Engel et al. (1993). Isto pode ser observado, para o caso específico de frutas, em pesquisa realizada por Dickson (1982). Este autor realizou uma pesquisa com 40 estudantes, nos EUA, onde foram investigadas as preferências dos mesmos em relação a oito tipos de frutas, em três diferentes situações de consumo. As frutas estudadas foram: uva, kiwi, maçã, ameixa, laranja, morango, banana e pêssego. As situações de consumo, por sua vez, foram: café da manhã, lanche durante o dia e sobremesa do jantar. Os resultados deste estudo são apresentados na Figura 13.

Pode-se perceber, na análise desta figura, que o pêssegos são altamente considerados nas três situações de consumo, sendo, inclusive, o tipo de fruta preferido no café da manhã e como lanche durante o dia. No entanto, as demais frutas têm o consumo variando bastante de acordo com a situação, principalmente no que se refere a morango, laranja e uva.

Os autores ainda mencionam que seria provável uma classificação diferente da preferência, caso fosse pesquisado outro grupo de consumidores, como idosos, por exemplo. Este tipo de análise está de acordo com a visão interacionista (Comportamento $=$ Situação + Indivíduo + [Siuação x Indivíduo]), adotada neste trabalho. 


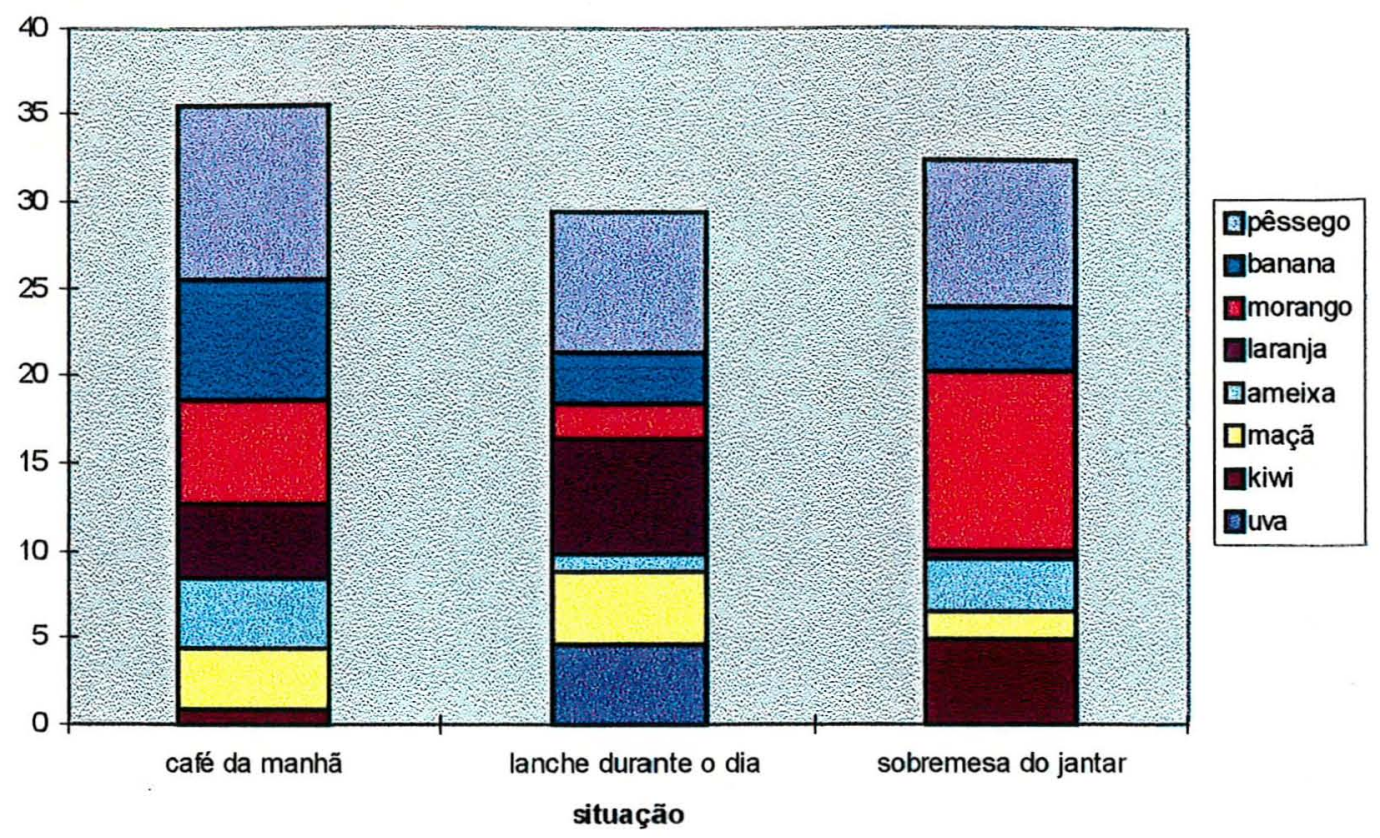

Figura 13: Preferência (\%) - Tipo de fruta x situação de consumo.

Fonte: Adaptado de Dickson (1982, p. 61)

\subsubsection{Sumário e contribuições}

Seguindo o modelo simplificado proposto anteriormente, foi feito um estudo, baseado em revisão de literatura nacional e internacional, de cada parte do processo de tomada de decisão de consumo para o caso do item frutas.

Ressalta-se ainda, que o processo de tomada de decisão foi dividido em três partes (pré-compra, compra e pós-compra), conforme proposto no modelo simplificado.

A partir desta revisão, surgiram diversas contribuições sobre o comportamento de consumo de frutas, que se desdobram nos itens apresentados a seguir, a partir dos quais será embasada a pesquisa exploratória. 
$\checkmark$ Pré-compra:

- Influências externas no consumo de frutas (atividades de marketing das empresas e influências socioculturais)

- Influências internas no consumo de frutas (risco percebido e conjunto evocado em relação ao consumo de frutas)

- Processo de tomada de decisão (reconhecimento do problema, busca de informação e avaliação das alternativas, para o caso específico de frutas)

$\checkmark$ Compra:

- Tipos de frutas adquiridos

- Situação de compra (ambiente de informação, ambiente de ponto de venda e influência temporal)

- Local de aquisição de frutas

- Atores no processo de compra

Pós-compra:

- Pré-consumo do produto (armazenamento e preparo)

- Consumo (situação de uso)

- Sensações pós-consumo

- Descarte 


\section{JUSTIFICATIVA E OBJETIVOS}

O setor agroindustrial, responsável pela produção de alimentos, é um setor de destaque na economia de muitos países. Para exemplificar sua importância basta mencionar que, em 1991, foi responsável por $17 \%$ dos empregos e $16 \%$ do Produto Nacional Bruto (PNB) dos Estados Unidos da América (EUA), conforme mencionado por Manchester (1992). No caso brasileiro, embora não se possa fazer uma comparação direta com a situação americana, devido a diferente agrupamento no setor, os valores são bastante significativos. O agribusiness movimentou, em 1990, US\$140,3 bilhões, sendo responsável por $40 \%$ do Produto Interno Bruto (PIB), de acordo com Araújo et al. (1991).

Apesar da importância do setor, há uma carência de estudos sobre o mercado consumidor de alimentos. Os dados disponíveis sobre consumo, no ENDEF (1978) e na POF (1991), são antigos e agrupados sob diferentes metodologias, dificultando comparações.

Neste cenário, um estudo que objetive esboçar melhor o mercado consumidor, através do estudo do processo de tomada de decisão de compra, para o setor frutícola, seria muito interessante, principalmente devido à ausência de estudos sobre o assunto. Neste contexto, uma análise inicial das características do setor com base em estudos já realizados e dados secundários, com utilização de um referencial teórico como ponto de partida, é bastante enriquecedora para melhor caracterização do setor. Posteriormente, a 
realização de uma pesquisa de campo, para especificar os resultados encontrados, vem a contribuir ainda mais para o desenvolvimento de um estudo deste tipo.

$O$ interesse pessoal pelo setor também justifica, adicionalmente, a escolha do tema. Este interesse pessoal pelo setor frutícola é oriundo de experiência profissional da pesquisadora, nesta área de atuação.

O objetivo geral do estudo é o de apresentar um modelo de comportamento de consumo adaptado para frutas, baseado na revisão de literatura nacional e internacional, obtendo, com a ajuda deste modelo, uma caracterização mais adequada sobre as decisões de consumo deste tipo de produto.

São questões específicas de investigação:

$\checkmark$ Caracterização da fase de pré-compra do processo de tomada de decisão de consumo de frutas:

- Influências externas no consumo de frutas (atividades de marketing das empresas e influências socioculturais).

- Influências internas no consumo de frutas (risco percebido e conjunto evocado em relação ao consumo de frutas).

- Processo de tomada de decisão (reconhecimento do problema, busca de informação e avaliação das alternativas, para o caso específico de frutas.

$\checkmark$ Caracterização da fase de compra do processo de tomada de decisão de consumo de frutas:

- Tipos de frutas adquiridos. 
- Situação de compra (ambiente de informação, ambiente de ponto de venda e influência temporal).

- Local de aquisição de frutas.

- Atores no processo de compra.

$\checkmark$ Caracterização da fase de pós-compra do processo de tomada de decisão de consumo de frutas:

- Pré-consumo do produto (armazenamento e preparo).

- Consumo (situação de uso).

- Sensações pós-consumo.

- Descarte 


\section{METODOLOGIA}

A pesquisa iniciou-se com o levantamento de um referencial teórico a respeito do processo de tomada de decisão de consumo, tanto para um indivíduo, como para uma familia, com o objetivo de embasar adequadamente o estudo. Também foram analisadas algumas características específicas do consumo de alimentos, focado em frutas in natura.

Dados secundários das pesquisas do IBGE (ENDEF e POF), Feedback, também foram analisados, principalmente para levantar características específicas do consumo de frutas no Brasil.

Com o uso deste material, chegou-se a um modelo de processo de decisão de compra, adaptado ao consumo de frutas in natura. Este modelo foi adaptado às principais características de cada fase do processo de tomada de decisão. As fases consideradas, neste estudo, são: pré-compra, compra e pós-compra.

Uma vez estabelecido o modelo, foi realizada uma pesquisa de campo, para verificar se ele é adequado e para determinar as características específicas do comportamento de consumo do produto em questão.

A pesquisa de campo consistiu em um estudo exploratório, devido à ausência de informações específicas sobre o assunto. Um estudo exploratório tem como finalidades: "desenvolver hipóteses, aumentar a familiaridade do investigador com um ambiente, fato 
ou fenômeno, para realização de uma pesquisa futura mais precisa ou modificar e clarificar conceitos", conforme evidenciam Marconi \& Lakatos (1990, p. 77).

Seeltiz et al. (1967, p. 60) também salientam os objetivos de um estudo exploratório. Segundo estes autores, "muitos estudos exploratórios têm como objetivo a formulação de um problema para investigação mais exata ou para criação de hipóteses". Além disso, um estudo exploratório pode ter outras funções, ainda de acordo com estes autores, tais como: aumentar o conhecimento do pesquisador a respeito do fenômeno que deseja investigar em estudo posterior, mais estruturado, ou da situação em que pretende realizar tal estudo; esclarecimento de conceitos; estabelecimento de prioridades para pesquisas futuras; obtenção de informação sobre possibilidades práticas de realização de pesquisa em situações de vida real.

Segundo Marconi \& Lakatos (1990, p. 77) pode-se usar, neste tipo de estudo, uma variedade de procedimentos de coleta de dados, como entrevista, observação participante, análise de conteúdo, entre outros, para o estudo relativamente intensivo de um pequeno número de unidades, geralmente sem o emprego de técnicas probabilísticas de amostragem.

Há diferentes tipos de entrevistas, que podem variar de acordo com os propósitos do investigador. De acordo com Marconi \& Lakatos (1990, p. 85), uma opção de entrevista é a entrevista padronizada ou estruturada. Neste caso o entrevistador segue um roteiro pré-estabelecido, ou formulário, para obter informações diretamente do entrevistado. Assim sendo, o que caracteriza um formulário é o contato face a face entre pesquisador e informante e ser o roteiro de perguntas preenchido pelo entrevistador, no momento da entrevista.

O motivo da padronização das entrevistas é obter, dos entrevistados, respostas às mesmas perguntas, permitindo "que todas elas sejam comparadas com o mesmo 
conjunto de perguntas, e que as diferenças devem refletir diferenças entre os respondentes e não diferenças nas perguntas", de acordo com Lodi' ${ }^{29}$, citado em Marconi \& Lakatos (1990, p. 85).

Kidder (1987b) ressalta algumas vantagens do uso de entrevistas. Segundo esta autora, as entrevistas geralmente produzem uma amostra mais adequada da população em estudo, uma vez que a porcentagem de pessoas dispostas a cooperar em um estudo deste tipo é relativamente elevada. Outra grande vantagem das entrevistas reside no fato de se permitir a correção de enganos dos informantes, que podem interpretar uma questão de maneira incorreta. Finalmente, ainda segundo Kidder (1987b), a situação de entrevista face a face tem a vantagem de permitir o uso de recursos visuais. $\mathrm{O}$ uso deste tipo de recurso pode vir a aumentar a taxa de respostas, assim como a validade das mesmas.

Neste estudo propôs-se, portanto, levantar os dados relevantes através de entrevistas estruturadas, com o uso de um formulário (Apêndice 1). Também foram utilizados recursos visuais em algumas das questões apresentadas (Apêndice 2). As entrevistas foram realizadas em unidades domiciliares, na cidade de Piracicaba, em dezembro de 1995. Foram realizadas entrevistas em 100 unidades domiciliares.

Com uma população estimada de 308631 habitantes (em 1995), o Município de Piracicaba tem aproximadamente $95 \%$ de sua população residindo na área urbana (Piracicaba, 1996). Ainda segundo Piracicaba (1996), o Município consolidou-se como importante centro de produção de cana-de-açúcar, em torno do qual formou-se importante complexo agroindustrial. Atualmente, a indústria do Município encontra-se bastante diversificada, com predomínio de estabelecimentos voltados para a produção de equipamentos destinados à indústria sucro-alcooleira. No entanto, também merecem destaque os setores produtores de material de transporte, material siderúrgico, papel e produtos químicos. O Município de Piracicaba, ainda de acordo com Piracicaba (1996),

${ }^{29}$ LODI, J. B. A entrevista: teoria e prática. $2^{\mathrm{a}}$ ed., São Paulo, Pioneira, 1974. 
também possui expressivo comércio atacadista e varejista, com estabelecimentos de origem local, além de lojas de departamentos nacionais, atraindo consumidores de cidades vizinhas, cuja popolação é estimada em mais de um milhão de habitantes. Em relação ao setor de prestação de serviços, há o emprego de mais de 20 mil pessoas. No setor agrícola, ainda hoje, a atividade mais importante é o cultivo da cana-de-açúcar. A cultura da laranja também tem se destacado na região. Estes números comprovam a importância da região de Piracicaba como polo regional de desenvolvimento, servindo como justificativa para escolha deste Município para realização da pesquisa de campo proposta.

Os domicílios base para pesquisa foram selecionados, dentro do Município de Piracicaba, através de dados fornecidos pela Prefeitura Municipal, a partir da listagem de endereços para cobrança do Imposto Predial e Territorial Urbano (IPTU).

Assim sendo, foi feita uma amostragem probabilística dos domicílios base para a realização das entrevistas. Esta escolha se deu devido ao fato das amostras probabilísticas envolverem certa segurança contra resultados ilusórios, conforme mencionado por Kidder (1987a).

O procedimento de amostragem adotado para escolha dos domicílios base foi o de amostragem aleatória simples, a partir de listagem de endereços fornecida pela Prefeitura Municipal de Piracicaba, conforme mencionado anteriormente. Em uma amostragem aleatória simples, de acordo com Ackoff (1967), cada elemento da população tem alguma e igual possibilidade de ser escolhido.

Para escolha da amostra, utilizou-se, portanto, uma função presente em um programa de computador, que selecionou números aleatórios entre 1 e 118000, uma vez que o Município de Piracicaba possui este número de endereços na listagem utilizada. Uma vez obtidos os números aleatórios, foram selecionados os endereços 
correspondentes. Utilizando estes endereços como base (42 endereços base, no total), foram realizadas as entrevistas.

Para viabilizar o estudo, foi adotada a seguinte metodologia: se o endereço selecionado não era apropriado para entrevista, ou seja, estivesse desocupado ou tratavase de um estabelecimento comercial, por exemplo, foi selecionado como base o segundo endereço à direita. Caso este endereço também não fosse adequado, optaria-se pelo segundo endereço à esquerda do selecionado pela listagem. Se ainda assim houvesse uma inadequação do local para aplicação da entrevista, seguia-se escolhendo residências, sempre pulando uma, primeiro à direita, depois à esquerda, a partir do endereço base.

Outra estratégia adotada, com o objetivo de operacionalizar o estudo, foi a escolha de mais duas residências a serem pesquisadas, por endereço base selecionado. Isto foi feito para otimizar o esforço de locomoção, uma vez que, caso houvesse algum empecilho à realização da entrevista, voltaria-se pelo menos três vezes ao local selecionado. A escolha destes outros dois endereços foi feita segundo metodologia semelhante à escolha do endereço base, pulando-se, no entanto, duas residências, primeiro à direita, depois à esquerda, a partir do endereço base, até encontrar duas residências também adequadas à entrevista.

Vale ainda ressaltar que, conforme classificação de Marconi \& Lakatos (1990), uma amostra aleatória pode ser de dois tipos: com reposição e sem reposição. $\mathrm{Na}$ amostragem com reposição os elementos da população podem entrar mais de uma vez para amostra. $\mathrm{Na}$ amostragem sem reposição, por sua vez, cada elemento só pode entrar uma vez para a amostra. No presente estudo, foi feita uma amostragem com reposição, devido ao programa utilizado.

Neste momento, deve-se mencionar que a opção pelo número de 100 entrevistados, assim como por uma região especifica, com utilização da metodologia de 
amostragem mencionada, foi feita com intenção de viabilizar o estudo exploratório, conduzido por esta pesquisadora.

O formulário utilizado para levantamento dos dados foi ainda submetido a um pré-teste, para que fossem corrigidas eventuais falhas do mesmo. $O$ pré-teste do questionário, segundo Seeltiz et al. (1967), consiste em uma "experiência" com o questionário, a fim de verificar se este está adequado e quais as mudanças necessárias, antes do início do estudo completo. Marconi \& Lakatos (1990, p. 90 e 91) mencionam ainda que o pré-teste serve para verificar se o questionário apresenta três importantes elementos: fidedignidade - qualquer pessoa que o aplique obterá os mesmos resultados; validade - os dados recolhidos são necessários à pesquisa; operatividade - vocabulário acessível e significado claro.

O pré-teste realizado ressaltou a necessidade de formular as questões de maneira mais acessível, com vocabulário bastante coloquial. Também foram feitas algumas alterações em algumas questões, para torná-las mais adequadas.

As questões apresentadas no formulário seguem a ordem proposta por Perrien et al. (1984) e por Miller (1977), na qual as questões sócio-demográficas são colocadas ao fim do questionário. Uma das razões para esta opção se encontra no fato deste tipo de pergunta ser facilmente respondido, mesmo quando o entrevistado estiver cansado, ao final da entrevista.

Também ressalta-se que o formulário foi aplicado em indivíduo que estava informado/ tinha conhecimento do processo de aquisição do produto, pois, desta maneira, foram respondidas tanto questões a respeito da aquisição como do consumo, uma vez que admitiu-se que este individuo tinha dados a respeito destes dois processos. $O$ objetivo deste tipo de metodologia foi facilitar a aplicação do formulário, pois este teve que ser aplicado em uma só pessoa por unidade domiciliar. 


\section{RESULTADOS E DISCUSSÃO}

Com o objetivo de testar o modelo de comportamento proposto, caracterizando as decisões de consumo de frutas, foram feitas entrevistas no Município de Piracicaba, em 100 unidades domiciliares, em dezembro de 1995.

Além dos dados referentes ao consumo de frutas, também foram coletadas informações gerais a respeito das unidades domiciliares onde foram realizadas as entrevistas. Estas informações foram coletadas com o objetivo de melhor caracterizar a amostra utilizada nesta pesquisa. Além disso, com a utilização destes dados, houve a possibilidade de se estratificar a amostra, auxiliando o processo de análise dos resultados.

Antes de iniciar a apresentação dos dados referentes ao comportamento de consumo de frutas, será apresentado o perfil da amostra pesquisada, de acordo com os dados gerais coletados.

A amostra pesquisada foi constituída de $52 \%$ de indivíduos do sexo feminino e $48 \%$ do sexo masculino, considerando todos os membros das unidades domiciliares. Em relação aos indivíduos nos quais foram aplicadas as entrevistas (entrevistados), tem-se $93 \%$ de indivíduos do sexo feminino e $7 \%$ do sexo masculino. A média de idade da amostra foi de 33,17 anos (35,53 anos para as mulheres e 30,64 anos para os homens). Em relação aos indivíduos entrevistados a média de idade foi de 43,58 anos $(43,43$ anos para as mulheres e 45,57 anos para os homens). A amplitude de idade dos indivíduos 
entrevistados foi de 16 a 82 anos. O número médio de moradores por unidade domiciliar foi de 3,79 indivíduos.

O consumo também foi analisado nesta fase da pesquisa, sendo atribuída uma participação no consumo de frutas para cada membro da unidade domiciliar. Neste aspecto, pode-se perceber que os indivíduos entrevistados, geralmente os responsáveis pela escolha e/ou compra do produto, parecem consumir mais frutas que os demais indivíduos, pois a média de consumo foi de $35,89 \%$, contra $26,33 \%$ para a amostra como um todo. Entre os individuos entrevistados, os homens parecem consumir mais frutas (média de $44,45 \%$, contra média de $35,25 \%$ para as mulheres). No entanto, quando consideramos a amostra como um todo, percebe-se que os indivíduos do sexo feminino parecem consumir mais frutas (média de $28,97 \%$ contra média de $23,5 \%$ para os homens). Estes dados servem apenas como indicativo do consumo, devendo ser tratados com extremo cuidado. Isso occorre pois o número de indivíduos por unidade domiciliar varia, distorcendo os resultados, que são expressos em porcentagem.

Em relação ao número de indivíduos que trabalham fora, por unidade domiciliar, tem-se $36 \%$ das residências com apenas um indivíduo trabalhando fora, $27 \%$ com dois, $16 \%$ com nenhum indivíduo trabalhando fora (aposentados), $13 \%$ com três, $6 \%$ com 4 e $2 \%$ com 5 indivíduos trabalhando fora.

$\mathrm{O}$ aspecto racial também foi analisado para esta amostra, sendo anotada, durante a entrevista, a cor do entrevistado. Neste aspecto, tem-se uma porcentagem de $91 \%$ da cor branca, $5 \%$ parda, $3 \%$ preta e $1 \%$ amarela.

O grau de instrução, tanto do entrevistado como do chefe da família, também foi 'evantado. Em relação a este fator, temos $97 \%$ dos indivíduos entrevistados alfabetizados, contra 3\% não alfabetizados. Dos alfabetizados, têm-se $35,06 \%$ dos indivíduos com até 4 anos de estudo, 23,7\% com 5 a 8 anos, 23,71\% com 9 a 11 anos e 
$17,52 \%$ com 12 ou mais anos de estudo. Já em relação ao chefe da familia, tem-se $99 \%$ de indivíduos alfabetizados e $1 \%$ não alfabetizados. Entre os alfabetizados, tem-se $36,99 \%$ dos indivíduos com até 4 anos de estudo, $19,19 \%$ com 5 a 8 anos, $20,54 \%$ com 9 a 11 anos e $23,28 \%$ com 12 ou mais anos de estudo. Vale salientar que, em $26 \%$ dos casos, o entrevistado era o chefe da família.

Em relação à atividade do entrevistado, nota-se que $61 \%$ dos individuos não trabalham fora da unidade domiciliar ( $44 \%$ donas de casa e $17 \%$ aposentado(a)s) e $39 \%$ trabalham.

A renda mensal média por unidade domiciliar da amostra pesquisada foi de R\$ 1747,00 . Se for considerada a renda per capita, tem-se uma renda média de $\mathrm{R} \$ 524,00$. O gasto semanal com frutas também foi analisado, obtendo-se um valor médio de $\mathrm{R} \$ 18,83$, por unidade domiciliar e $\mathrm{R} \$ 5,64$ per capita.

A partir destes dados gerais, foram selecionados alguns fatores para a estratificação, tais como: idade do entrevistado (dois estratos: até 42 anos, com $50 \%$ dos entrevistados e acima de 42 anos, também com $50 \%$ dos entrevistados), escolaridade do entrevistado (três estratos: até 4 anos de estudo - 37\% dos entrevistados, 5 a 8 anos $23 \%$ e acima de 8 anos - 40\%), fato do entrevistado trabalhar fora (39\% dos entrevistados) ou não (61\%), renda per capita (três estratos: até R\$180,00 - 33\% dos entrevistados, de $R \$ 181,00$ até $R \$ 450,00-33 \%$ e acima de $R \$ 451,00-34 \%$ ), gasto semanal per capita com frutas (três estratos: até $\mathrm{R} \$ 2,99$ - 36\% dos entrevistados, de $R \$ 3,00$ a $R \$ 5,00-36 \%$ e acima de $R \$ 5,01-28 \%$ ) e presença ou não de indivíduos menores de 18 anos na unidade domiciliar, com 59\% das residências apresentando indivíduos menores.

É importante salientar que a estratificação dos resultados foi feita após a realização das entrevistas, com base nos resultados apresentados. Desta maneira, foram 
estabelecidos os limites dos estratos, com base nos dados das entrevistas, evitando o surgimento de estratos com número reduzido de entrevistados, uma vez que isso poderia prejudicar a análise dos dados, devido ao número reduzido de indivíduos pesquisados. Além disso, pode-se notar que foram estabelecidos no máximo três estratos para cada fator avaliado. O motivo, neste caso, também foi evitar o aparecimento de estratos com número reduzido de indivíduos.

Finalmente, serão apresentados os resultados da pesquisa de campo por fases do processo de tomada de decisão de consumo, de acordo com o modelo proposto. Assim sendo, a apresentação dos resultados se iniciará com a fase de pré-compra, onde, após o reconhecimento da necessidade, o consumidor busca informações e avalia as alternativas disponíveis, utilizando suas experiências anteriores. Nesta fase, também ocorrem influências externas no comportamento de consumo.

A fase seguinte é a da compra propriamente dita. Nesta fase, ocorrem as opções de compra e as atividades relacionadas à aquisição da alternativa selecionada.

A pós-compra, terceira fase do processo, envolve várias atividades relacionadas à manipulação, ao consumo e ao pós-consumo dos produtos adquiridos. Nesta fase, o consumidor acumulará sensações associadas com uso, preparo, armazenamento e até descarte do produto. Conforme mencionado anteriormente, este estágio é muito importante, pois pode vir a influenciar as atitudes e comportamentos futuros dos consumidores.

\subsection{Pré-compra}

De acordo com o modelo proposto, a fase de pré-compra será discutida em três frentes: influências externas, influências internas e processo de tomada de decisão de consumo de frutas. 
As influências externas no consumo de frutas consistem nas atividades de marketing das empresas e influências socioculturais.

As influências socioculturais no consumo de frutas, como família, fontes informais e não comerciais de informação, classe social (englobando itens como renda, ocupação e educação) e idade serão discutidas no decorrer da apresentação dos resultados, uma vez que os dados foram estratificados por fatores como estes.

Em relação às atividades de marketing das empresas, foram analisados fatores relacionados ao produto, como embalagem, e às atividades promocionais.

Em relação à embalagem, pode-se detectar que a maioria dos consumidores adquire produtos a granel ( $97 \%$ dos entrevistados). Apenas $1 \%$ dos consumidores adquirem apenas produtos embalados e $2 \%$ adquirem ambos os tipos. Analisando este aspecto seguindo a divisão por estratos, não houve variação significativa nos diversos estratos analisados, conforme pode ser observado na Tabela 23.

Os motivos da escolha do produto a granel (Tabela 24) apresentados pelos consumidores foram: possibilidade de escolha do produto (54\%), disponibilidade no mercado $(28 \%)$, preço $(7 \%)$, qualidade $(5 \%)$, porção adequada $(4 \%)$, frescor $(2 \%)$, higiene $(1 \%)$ e costume (1\%). Ao realizar a estratificação ocorreram algumas mudanças nestes resultados. A disponibilidade e o preço apresentaram uma importância maior para a faixa de idade acima de 42 anos, mencionadas por $31 \%$ e $10 \%$ dos entrevistados, respectivamente. Na faixa até 42 anos, estes fatores foram citados por $25 \%$ e $4 \%$ dos entrevistados. A possibilidade de escolha e a qualidade, por sua vez, apareceram com importância maior para a faixa até 42 anos, mencionadas por $60 \%$ e $7 \%$, dos entrevistados, respectivamente. Na outra faixa (acima 42 anos), a menção destes fatores foi de $47 \%$ e $2 \%$. 

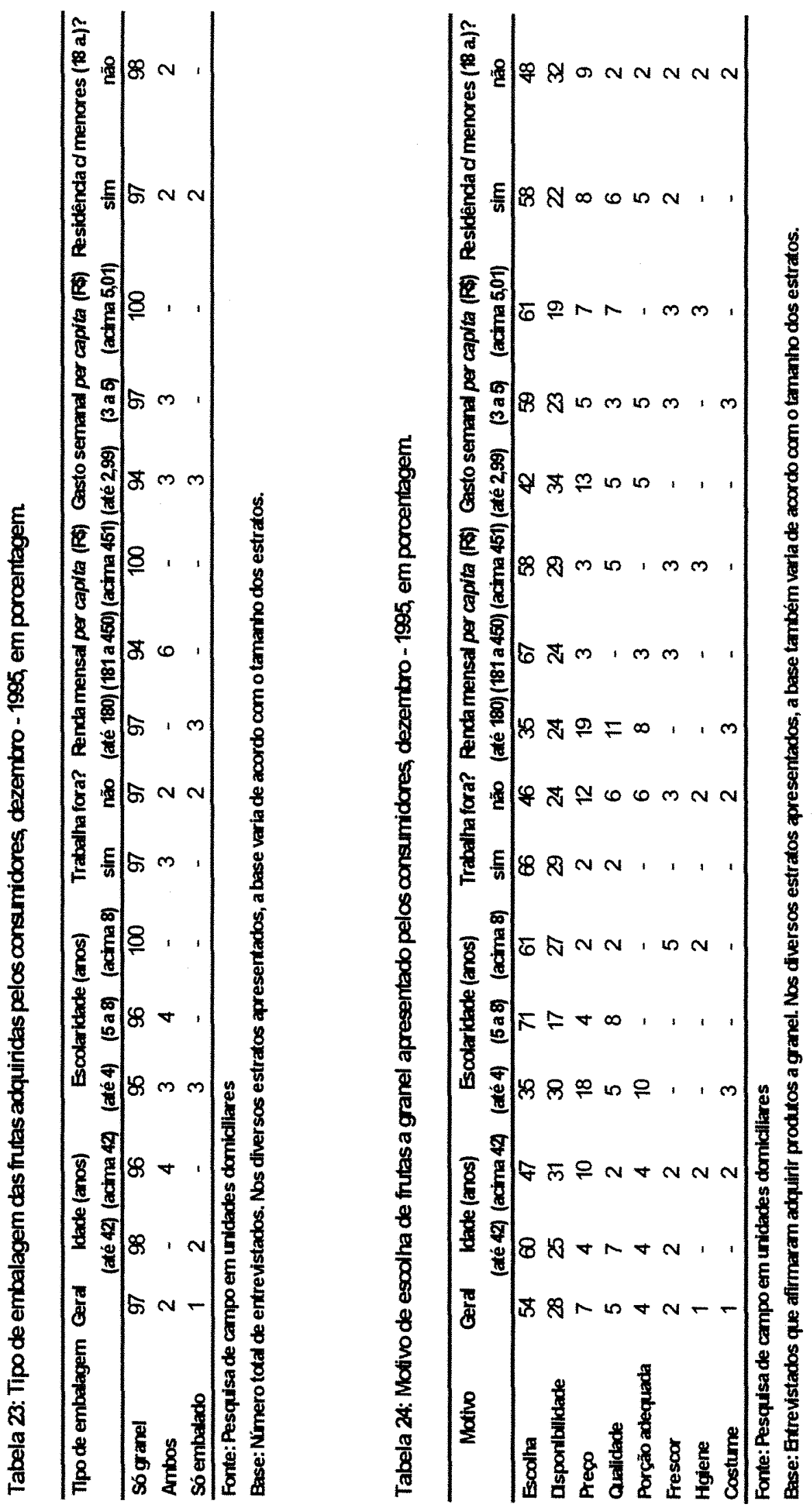
$\mathrm{O}$ número de anos de estudo parece interferir principalmente em fatores como possibilidade de escolha, disponibilidade e preço. Em relação à possibilidade de escolha parece haver uma tendência de aumento de importância com um maior número de anos de estudo, uma vez que este fator foi mencionado por $35 \%$ dos entrevistados com até 4 anos de estudo, $71 \%$ dos entrevistados na faixa de 5 a 8 anos de estudo e $61 \%$ com mais de 8 anos de estudo. A disponibilidade parece ter uma importância menor na faixa de 5 a 8 anos de estudo, mencionada por $17 \%$ dos entrevistados, contra $30 \%$ na faixa até 4 anos e $27 \%$, na faixa acima de 8 anos. O preço, por sua vez, despontou como mais importante na faixa até 4 anos de estudo, com $18 \%$ das menções, contra $4 \%$ na faixa intermediária e $2 \%$ na faixa de maior número de anos de estudo.

Em relação ao fato do entrevistado trabalhar ou não fora de casa, a possibilidade de escolha parece ter maior importância para os indivíduos que trabalham fora $(66 \%$ das menções, contra $46 \%$ para os que não trabalham). A disponibilidade também foi mais importante para quem trabalha fora ( $29 \%$ contra $24 \%$ para quem não trabalha). O preço do produto, por sua vez, foi mais importante para quem não trabalha fora ( $12 \%$ contra $2 \%$ na outra faixa). Os demais fatores, como qualidade, porção adequada, frescor, higiene e costume, também apresentaram uma importância um pouco maior para os indivíduos que não trabalham fora.

A possibilidade de escolha apresentou uma tendência de maior importância conforme a renda per capita aumenta (35\% das menções na faixa até $R \$ 180,00 ; 67 \%$ na faixa de $\mathrm{R} \$ 181,00$ a $\mathrm{R} \$ 450,00 ; 58 \%$ na faixa acima de $\mathrm{R} \$ 451,00$ ). A disponibilidade foi mais importante na faixa de renda maior ( $29 \%$, contra $24 \%$ nas outras duas faixas). $O$ preço, como esperado, foi mais importante na faixa de renda mais baixa (19\% das menções, contra $3 \%$ na faixa intermediária e 3\% na faixa de renda mais alta). A qualidade, por sua vez, apresentou uma importância maior na faixa de renda menor ( $11 \%$ das menções), seguida da faixa de renda maior (5\%). Na faixa intermediária, não houve menção deste fator. 
A estratificação por gasto semanal per capita com frutas interferiu principalmente na importância dos fatores possibilidade de escolha, disponibilidade e preço. A importância da possibilidade de escolha aumentou com o gasto $(42 \%$ das menções na faixa até $\mathrm{R} \$ 2,99 ; 59 \%$ na faixa de $\mathrm{R} \$ 3,00$ a $\mathrm{R} \$ 5,00 ; 61 \%$ na faixa acima de R\$ 5,01). A disponibilidade teve sua importância diminuindo com o aumento do gasto semanal ( $34 \%$ das menções na faixa até $R \$ 2,99 ; 23 \%$ na faixa de $R \$ 3,00$ a $R \$ 5,00$; $19 \%$ na faixa acima de R $\$ 5,01$ ). O fator preço, por sua vez, parece ter importância maior na faixa de menor gasto $(13 \%$, contra $5 \%$ na faixa intermediária e $7 \%$ na faixa de maior gasto).

Finalmente, o fato de haver ou não indivíduos menores de 18 anos na residência também parece interferir no padrão de importância dos motivos de escolha de frutas a granel. A possibilidade de escolha teve maior importância nas residências onde existem indivíduos menores de 18 anos ( $58 \%$, contra $48 \%$ onde há só adultos). A disponibilidade foi mais importante para residências só com adultos ( $32 \%$ contra $22 \%$ ). O preço também parece ter importância um pouco maior em residências só com adultos ( $9 \%$ contra $8 \%$ ). Já o fator qualidade, despontou como mais importante em residências com indivíduos menores ( $6 \%$ das menções, contra $2 \%$ na outra faixa).

Quando a opção foi por produto embalado, o único motivo apresentado foi a qualidade dos produtos, conforme pode ser observado na Tabela 25. Já quando os indivíduos compram ambos os tipos de produtos (embalado e granel), o único motivo apresentado foi a disponibilidade (Tabela 26).

Estes dados, de maneira geral, comprovam tendência levantada na revisão de literatura, de que o consumidor brasileiro prefere frutas sem embalagem, principalmente devido à possibilidade de escolher melhor os produtos devido ao manuseio. Desta maneira, este tipo de produto, geralmente, é apresentado a granel para os consumidores. 


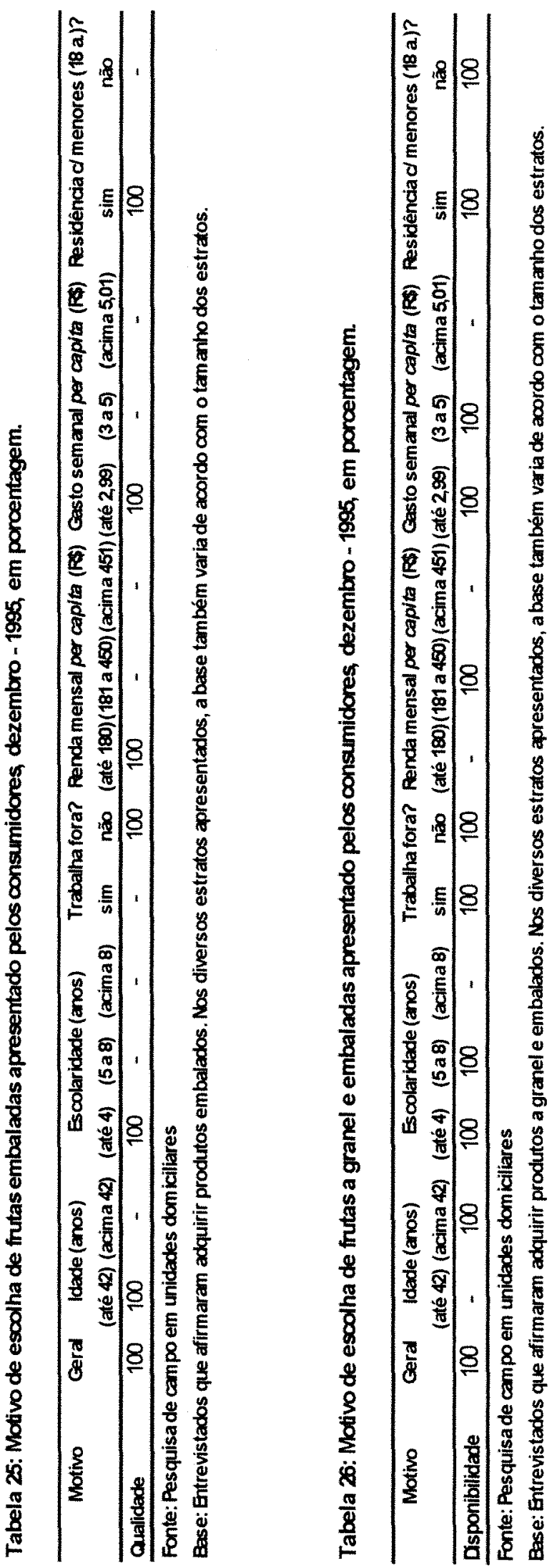


Em relação às atividades promocionais observadas pelos consumidores, ressaltou-se que $31 \%$ dos entrevistados não perceberam qualquer tipo de atividade promocional relacionada ao item frutas, $25 \%$ notaram descontos, $16 \%$ tiveram contato com propagandas (jornais, revistas, rádio e televisão), $9 \%$ notaram cartazes, $8 \%$ folhetos, $8 \%$ experimentações gratuitas, $3 \%$ outdoors e $1 \%$ propaganda sonora na rua, conforme pode ser observado na Tabela 27.

As diferenças por estratos para os principais tipos de atividades promocionais observados são apresentadas a seguir.

A porcentagem de indivíduos que não reparou em qualquer tipo de atividade promocional foi maior na faixa acima de 42 anos ( $44 \%$ contra $21 \%$ na outra faixa). Os descontos, por sua vez, foram mais observados por individuos da faixa até 42 anos (31\% contra $17 \%$ ). Propagandas em jornais, revistas, rádio e televisão foram mais observadas pelos indivíduos da faixa acima de 42 anos (17\% contra 14\%). Finalmente, os folhetos também se destacaram na faixa até 42 anos, com 14\% das menções (contra $3 \%$ na outra faixa).

Em relação ao grau de escolaridade dos entrevistados, as principais variações podem ser notadas na porcentagem de individuos que não notou qualquer tipo de atividade promocional e descontos. $\mathrm{O}$ número de indivíduos que não observou qualquer tipo de atividade promocional foi maior na faixa até 4 anos de estudo (51\%), seguido da faixa de maior número de anos de estudo (25\%). A faixa intermediária apresentou o menor número de indivíduos não percebendo qualquer tipo de atividade promocional relacionada às frutas $(9 \%)$. Já em relação aos descontos, a porcentagem de observação deste tipo de atividade teve uma tendência de aumento com o maior número de anos de estudo ( $13 \%$ das menções na faixa até 4 anos de estudo, $31 \%$ na faixa intermediária e $31 \%$ na faixa acima de 8 anos de estudo). 


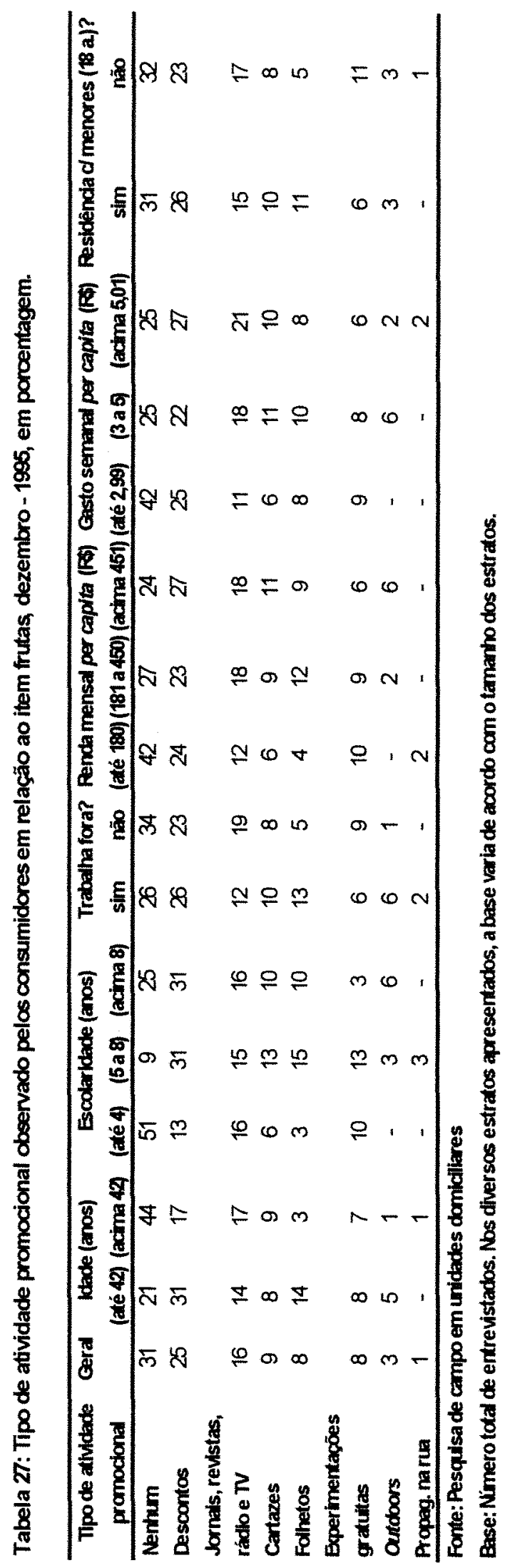


O fato do individuo trabalhar ou não fora de casa também parece causar algumas diferenças no tipo de atividade promocional observado. Os individuos que trabalham fora de casa foram mais observadores em relação a descontos e folhetos $(26 \%$ e $13 \%$ das menções, respectivamente, contra $23 \%$ e $5 \%$ na outra faixa). Já os indivíduos que não trabalham foram mais observadores em relação a propagandas em jornais, revistas, rádio e televisão $(19 \%$ contra $12 \%)$. Em relação à não percepção de atividades promocionais, os indivíduos que não trabalham apresentaram uma tendência maior de não notar qualquer tipo de atividade promocional ( $34 \%$, contra $26 \%$ na outra faixa).

A renda per capita também parece causar algumas alterações no padrão de observação de atividades promocionais. O número de indivíduos que não notou qualquer tipo de atividade decresceu com o aumento da renda ( $42 \%$ na faixa de menor renda, $27 \%$ na faixa intermediária e $24 \%$ na faixa de maior renda). Os descontos foram mais observados pelos individuos da faixa de maior renda ( $27 \%$, contra $24 \%$ na faixa de menor renda e $23 \%$ na faixa intermediária). Em relação à observação de propagandas em jornais, revistas, rádio e televisão, houve uma tendência de aumento na porcentagem de observação de acordo com a renda ( $12 \%$ na faixa de renda mais baixa, $18 \%$ na faixa de renda intermediária e $18 \%$ na faixa de renda mais alta).

Em relação ao gasto semanal per capita com frutas, o número de indivíduos que não observou qualquer tipo de atividade promocional foi maior na faixa de menor gasto ( $42 \%$ contra $25 \%$ nas demais faixas). A observação de descontos, por sua vez, foi maior na faixa de maior gasto $(27 \%)$, seguida da faixa de menor gasto $(25 \%)$ e intermediária $(22 \%)$. Já as propagandas em jornais, revistas, rádio e televisão foram mais observadas com o aumento do gasto com frutas ( $11 \%$ das observações na faixa até $\mathrm{R} \$ 2,99,18 \%$ na faixa de $R \$ 3,00$ a $R \$ 5,00$ e $21 \%$ na faixa acima de $R \$ 5,01$ ).

Finalmente, em relação a presença ou não de indivíduos menores de 18 anos nas residências, o número de indivíduos entrevistados que não notou qualquer tipo de 
atividade promocional foi um pouco maior nas unidades domiciliares somente com adultos ( $32 \%$ contra $31 \%$ nas residências com indivíduos menores). O número de observações de propagandas em jornais, revistas, rádio e televisão também foi maior nas unidades domiciliares compostas unicamente por indivíduos adultos ( $17 \%$ contra $15 \%$ na outra faixa). Já em relação à percepção de descontos, os entrevistados pertencentes a unidades domiciliares com indivíduos menores parecem se destacar ( $26 \%$ contra $23 \%$ ).

As influências internas no comportamento de consumo estão relacionadas ao campo psicológico no modelo proposto. Neste aspecto, existem dois fatores chave a serem considerados. São eles: risco percebido e conjunto evocado.

Risco percebido, conforme definido anteriormente, se relaciona à incerteza que os consumidores sentem quando não conseguem prever as conseqüencias de suas decisões de compra.

Em relação ao consumo de alimentos, existe uma crescente preocupação com riscos à saúde causados pela presença de contaminações ou produtos químicos nos produtos ingeridos. Também há uma preocupação crescente em relação à ingestão de alimentos saudáveis. Como o produto analisado, frutas, consiste em um alimento, o risco percebido foi analisado dentro deste enfoque. Assim sendo, para analisar o risco percebido, foram levantados dados relacionados a: motivo de consumo de frutas, preocupações com a saúde influenciando o consumo de frutas, preocupações com resíduos químicos nas frutas e consumo de produtos orgânicos.

Os motivos de consumo de frutas destacados na pesquisa de campo foram: saúde (52\% dos entrevistados), sabor $(36 \%)$, dieta $(9 \%)$, hábito $(2 \%)$ e praticidade/ facilidade de consumo ( $2 \%$ ), como pode ser observado na Tabela 28 . 


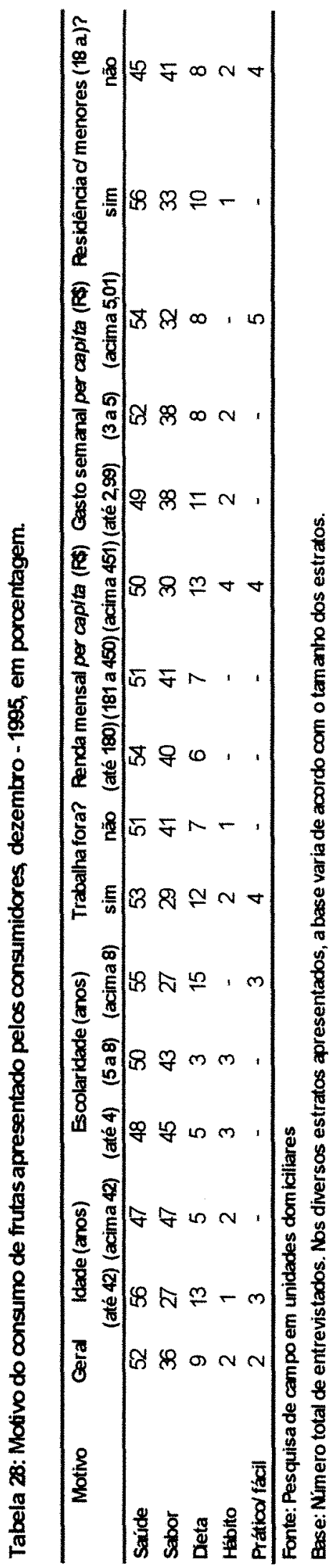


Pode-se observar também uma variação nos resultados quando se faz a estratificação. Em relação à idade do entrevistado, pode-se notar que a saúde parece ser a variável mais importante para os individuos com até 42 anos (56\% contra $47 \%$ para os indivíduos com mais de 42 anos). O sabor, por sua vez, despontou como mais importante para os indivíduos mais velhos (47\% contra $27 \%$ para os indivíduos com até 42 anos). 0 hábito também foi mais citado como motivo relevante de consumo pelos indivíduos acima de 42 anos ( $2 \%$ contra $1 \%$ no outro estrato). Já a dieta e a praticidade/ facilidade de consumo foram considerados motivos de consumo mais importantes para os individuos mais novos (13\% e 3\%, respectivamente, contra 5\% e $0 \%$ para os indivíduos com mais de 42 anos).

A escolaridade também parece afetar os motivos de consumo. A saúde foi mais citada como motivo de consumo pelos indivíduos com maior grau de escolaridade (55\% para a faixa com mais de 8 anos de estudo, contra 50\% para a faixa intermediária e $48 \%$ para a faixa com até 4 anos de estudo). O sabor, por sua vez, apareceu como mais importante para os indivíduos com menor grau de escolaridade (citado por $45 \%$ dos entrevistados da faixa com menor escolaridade, $43 \%$ da faixa intermediária e apenas $27 \%$ da faixa com maior escolaridade). A dieta, assim como a saúde, também foi mais citada como motivo de consumo pelos individuos com maior escolaridade (15\% na faixa com maior número de anos de estudo, contra $3 \%$ na faixa intermediária e $5 \%$ na faixa com menor número de anos de estudo). O hábito só foi citado como motivo de consumo pelas faixas de baixa e média escolaridade (motivo de escolha para 3\% dos entrevistados destas faixas). Finalmente, a praticidade/ facilidade de consumo só foi citada como motivo de consumo pelos indivíduos de maior escolaridade ( $3 \%$ dos entrevistados).

Em relação ao fato do entrevistado trabalhar ou não fora da unidade domiciliar, também despontaram algumas possíveis indicações de alterações nos motivos de consumo. A saúde aparece com uma importância um pouco maior para os indivíduos que trabalham fora (53\% contra $51 \%$ na outra faixa). O sabor, por sua vez, foi considerado 
mais importante para os indivíduos que não trabalham fora ( $41 \%$, contra $29 \%$ para os indivíduos que trabalham fora). A dieta e o hábito foram citados, respectivamente, como motivo de consumo por $12 \%$ e $2 \%$ dos entrevistados que trabalham fora, contra $7 \%$ e $1 \%$ de citações entre os indivíduos que não trabalham. A praticidade/ facilidade de consumo, como esperado, foi citada como motivo de consumo apenas pelos indivíduos que trabalham fora ( $4 \%$ dos entrevistados).

A renda per capita, por sua vez, também parece influenciar os motivos de consumo. A saúde parece ser mais importante para a faixa de menor renda ( $54 \%$ contra $51 \%$ para a faixa intermediária e $50 \%$ para a faixa de maior renda). O sabor também parece ser importante para as faixas intermediária e de menor renda $(41 \%$ e $40 \%$, respectivamente, contra $30 \%$ para a faixa de maior renda). A dieta, por sua vez, aparece como motivo de consumo com maior intensidade para a faixa de maior renda ( $13 \%$ contra $7 \%$ para a faixa intermediária e $6 \%$ para a faixa de menor renda). O hábito e a praticidade/ facilidade de consumo só foram citados como motivo de consumo pela faixa de maior renda ( $4 \%$ dos entrevistados em ambos os casos).

A citação da saúde como motivo de consumo também parece sofrer influência do gasto semanal per capita com frutas. Quanto maior o gasto, maior número de indivíduos apresentaram a saúde como motivo do consumo de frutas ( $54 \%$ na faixa de maior gasto, contra $52 \%$ na faixa intermediária e $49 \%$ na faixa de menor gasto). O sabor, por sua vez, teve sua importância diminuída com o maior gasto semanal ( $32 \%$ na faixa de maior gasto, contra $38 \%$ nas demais faixas). A dieta despontou como motivo com maior intensidade na faixa de menor gasto ( $11 \%$, contra $8 \%$ nas demais faixas). O hábito só apareceu como motivo de consumo para as faixas de menor gasto e intermediária $(2 \% \mathrm{em}$ ambas as faixas). Finalmente, a praticidade/ facilidade de consumo só foi destacada como motivo de consumo para a faixa de maior gasto semanal ( $5 \%$ dos entrevistados) 
$\mathrm{O}$ fato de existirem ou não menores de 18 anos nas unidades domiciliares também parece influenciar o motivo de consumo. A saúde foi destacada como motivo de consumo com maior intensidade nas unidades domiciliares com indivíduos menores de 18 anos ( $56 \%$, contra $45 \%$ nas unidades onde só há adultos). O sabor foi considerado mais importante em unidades domiciliares onde só existem adultos ( $41 \%$, contra $33 \%$ na outra faixa). A dieta, assim como a saúde, foi considerada motivo de consumo com maior intensidade em unidades domiciliares com indivíduos menores (10\% contra $8 \%$ ). Finalmente, o hábito e a praticidade/ facilidade de consumo apareceram com maior destaque em unidades domiciliares só com adultos (respectivamente $2 \%$ e $4 \%$, contra $1 \%$ e $0 \%)$

Os entrevistados também foram avaliados em relação à influência das preocupações com a saúde sobre o consumo de frutas (Tabela 29). Neste caso, $88 \%$ dos entrevistados disseram que as preocupações com a saúde estimulam o consumo de frutas. Somente $12 \%$ dos entrevistados afirmaram que as preocupações com a saúde não tem influência no consumo de frutas. 


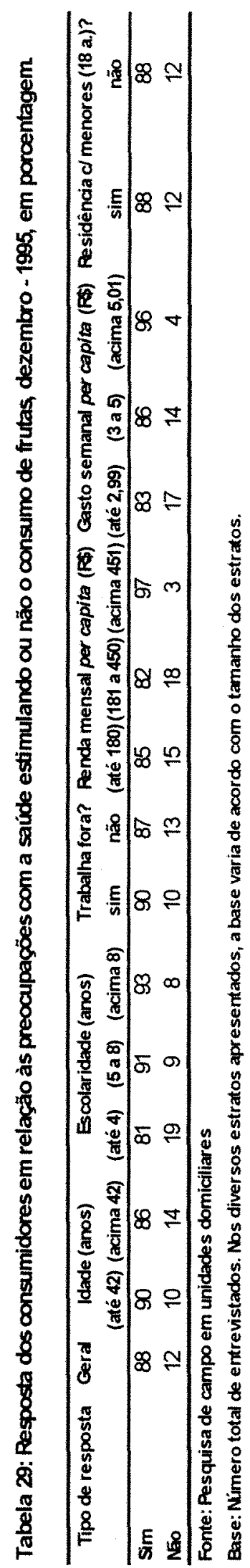


Analisando os dados por estratos, pode-se perceber que o consumo de frutas foi mais influenciado pelas preocupações com a saúde na faixa de idade até 42 anos ( $90 \%$ dos entrevistados, contra $86 \%$ na faixa acima de 42 anos). O consumo de frutas também parece ser estimulado pelas preocupações com a saúde, com maior intensidade, conforme o grau de escolaridade aumenta ( $93 \%$ para a faixa acima de 8 anos de estudo, $91 \%$ para a faixa intermediária e $81 \%$ para a faixa com menor grau de escolaridade). Os indivíduos que trabalham fora também parecem consumir mais frutas devido à saúde $(90 \%$, contra $87 \%$ para os indivíduos que não trabalham). Os indivíduos da faixa de maior renda também parecem estar mais influenciados por preocupações com a saúde quando decidem consumir frutas $(97 \%$, contra $82 \%$ na faixa de renda intermediária e $85 \%$ na faixa de menor renda). $\mathrm{O}$ aumento do gasto semanal per capita com frutas também faz com que aumente a influência das preocupações com a saúde no consumo de frutas ( $96 \%$, contra $86 \%$ na faixa intermediária e $83 \%$ na faixa de menor gasto). Já o fato de haver ou não indivíduos menores de 18 anos na unidade domiciliar não parece influenciar o resultado da pesquisa.

Para os indivíduos que disseram ser influenciados por preocupações com a saúde quando decidem sobre o consumo de frutas foi questionado qual o motivo desta interferência. Conforme pode ser observado na Tabela 30, os principais motivos que levam os indivíduos a consumir frutas por causa das preocupações com a saúde foram: vitaminas ( $45 \%$ dos entrevistados), "faz bem", sem saber ao certo o motivo ( $25 \%$ dos entrevistados) e auxilia digestão/ intestino ( $14 \%$ dos entrevistados). Também foram citados como motivos fatores como: ser mais leve em relação a outros alimentos $(6 \%)$, sentir-se bem quando consome frutas (4\%), frutas têm menos açúcar que outros alimentos $(4 \%)$, e sugestão médica $(3 \%)$. 


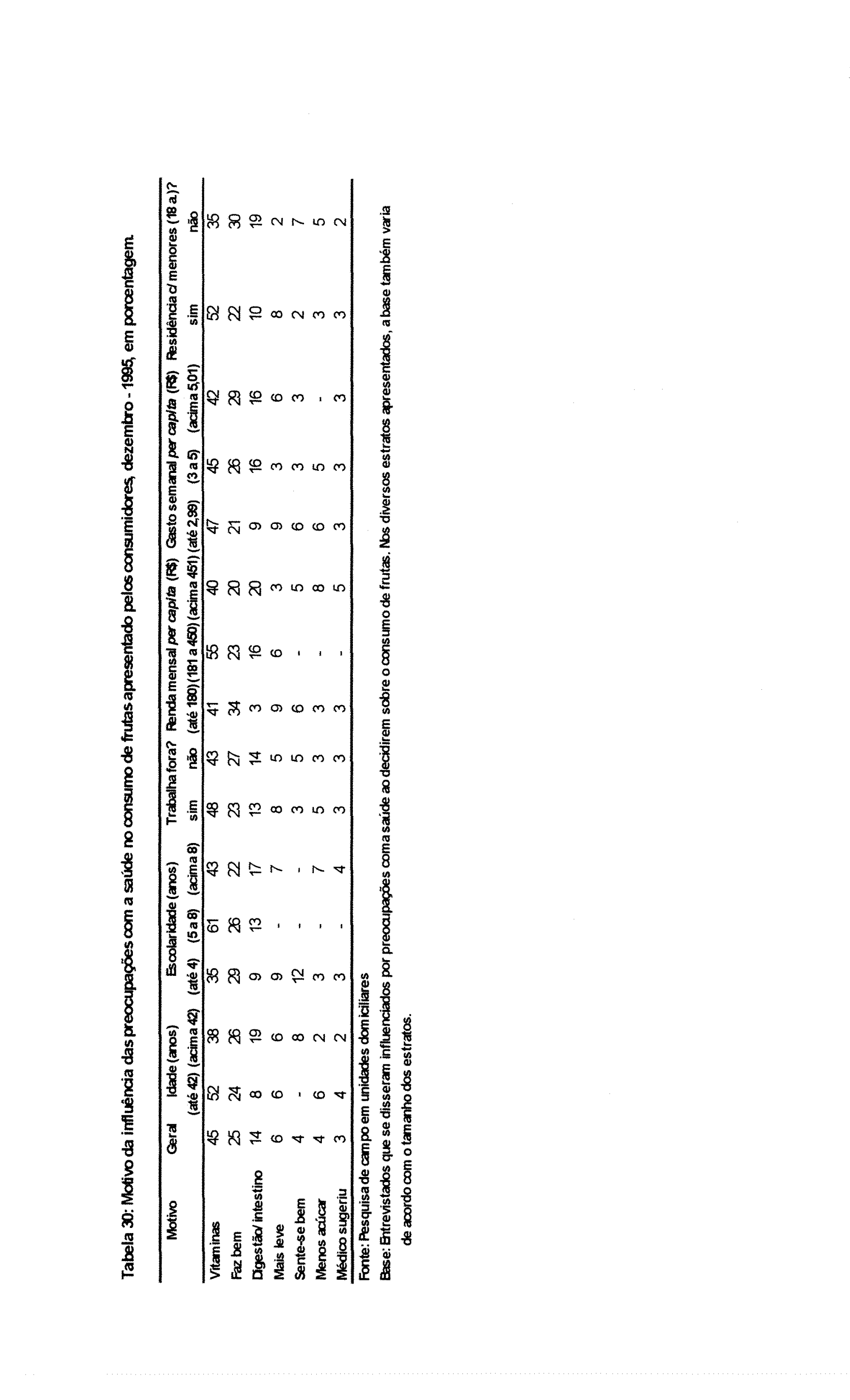


Analisando os três principais motivos da influência das preocupações com a saúde no consumo de frutas, pode-se perceber que, na faixa de idade até 42 anos, houve uma maior importância das vitaminas ( $52 \%$, contra $38 \%$ na faixa acima de 42 anos). Já os indivíduos da faixa etária mais elevada parecem ser mais influenciados pelo auxilio à digestão/ intestino (19\%, contra $8 \%$ no outro estrato). Além disso, o número de indivíduos que disseram que a influência ocorre pois as frutas "fazem bem" também aumenta entre os individuos com mais de 42 anos ( $26 \%$ contra $24 \%$ entre os indivíduos com até 42 anos).

A escolaridade também parece alterar os motivos da influência das preocupações com a saúde no consumo de frutas. As vitaminas aparecem com maior importância para a faixa de escolaridade intermediária ( $61 \%$ dos entrevistados), seguida pela faixa de maior escolaridade (43\%) e menor escolaridade (35\%). Os indivíduos que apresentam como motivo apenas "faz bem" foram mais numerosos na faixa de menor escolaridade $(29 \%$, contra $26 \%$ na faixa intermediária e $22 \%$ na faixa de maior escolaridade). Já a motivação direcionada pelo auxilio à digestão/ intestino foi maior na faixa de maior escolaridade ( $17 \%$, contra $13 \%$ na faixa intermediária e $9 \%$ na faixa de menor nível de escolaridade).

Em relação ao fato do indivíduo trabalhar ou não fora da residência, as principais diferenças podem ser notadas em relação a vitaminas e a "faz bem". O número de individuos que se motiva devido às vitaminas foi maior entre os que trabalham fora (48\%, contra $43 \%$ entre os que não trabalham). Já quando o motivo apresentado foi "faz bem", os indivíduos que não trabalham fora se destacam $(27 \%$, contra $23 \%$ para os que trabalham fora).

A renda per capita também parece afetar os padrões de resposta. As vitaminas foram destacadas com maior intensidade na faixa de renda intermediária $(55 \%$ dos entrevistados), seguida pela faixa de menor renda (41\%) e pela de maior renda $(40 \%)$. $O$ motivo "faz bem" foi mais citado na faixa de menor renda (34\%, contra $23 \%$ na faixa 
intermediária e $20 \%$ na faixa de maior renda). Já o fato de auxiliar a digestão foi mais mencionado na faixa de maior renda $(20 \%$, contra $16 \%$ na faixa intermediária e apenas $3 \%$ na faixa de menor renda).

As vitaminas, quando analisa-se o padrão de resposta de acordo com as faixas de gasto semanal per capita com frutas, foram mais mencionadas pelos indivíduos com menor gasto ( $47 \%$, contra $45 \%$ na faixa intermediária e $42 \%$ na faixa de maior gasto). $\mathrm{O}$ motivo "faz bem", por sua vez, foi mais mencionado na faixa de maior gasto semanal $(29 \%)$, seguido das faixas de gasto intermediário (26\%) e menor gasto (21\%). Finalmente, o auxilio à digestão/ intestino foi mais destacado nas faixas de gasto intermediário e maior ( $16 \%$ em ambas, contra $9 \%$ na de menor gasto).

O fato de haver ou não indivíduos com menos de 18 anos na unidade domiciliar também parece interferir no padrão de respostas. As vitaminas foram mais citadas pelos entrevistados cujas residências possuem indivíduos menores $(52 \%$, contra $35 \%$ onde há só adultos). O "faz bem", por sua vez, foi mais citado nas unidades domiciliares somente com indivíduos adultos $(30 \%$, contra $22 \%$ na outra faixa). Finalmente, o auxilio à digestão/ intestino também foi mais mencionado na faixa que engloba as unidades domiciliares só com adultos ( $19 \%$ contra $10 \%)$.

Os consumidores também parecem preocupados com a presença de resíduos químicos nas frutas que consomem, como pode ser observado na Tabela 31. Entre os individuos entrevistados, $51 \%$ disseram se preocupar com os resíduos, lavando bem as frutas ou descascando-as antes do consumo, 19\% afirmaram que estão preocupados, mas não há nada que possa ser feito para evitar a ingestão destes resíduos e $1 \%$ afirmaram que também estão preocupados com este fato, por isso preferem produtos de pomares caseiros. Existem também consumidores que se declararam apenas um pouco preocupados com o assunto ( $6 \%$ dos entrevistados) e, finalmente, uma parte deles afirmou não se preocupar com isso ( $23 \%$ dos entrevistados). 
Analisando a preocupação com ingestão de produtos químicos por faixa etária, pode-se perceber que os indivíduos mais novos parecem estar menos preocupados com a ingestão destes resíduos, uma vez que $24 \%$ dos indivíduos até 42 anos disseram não se preocupar com o assunto (contra $22 \%$ no outro estrato) e $10 \%$ afirmaram estar apenas um pouco preocupados (contra $2 \%$ dos indivíduos acima de 42 anos). A porcentagem de indivíduos que se afirmaram preocupados com o assunto, mas que não há nada que possa ser feito a respeito, aumentou no estrato mais idoso.

Em relação à escolaridade dos indivíduos entrevistados, não foi possível notar um padrão bem definido da influência da estratificação no padrão de respostas, como pode ser também observado na Tabela 31 .

Já o fato do indivíduo trabalhar ou não fora parece influenciar o padrão de resposta. Os indivíduos que trabalham fora parecem menos preocupados com a ingestão de resíduos químicos, uma vez que $28 \%$ dos entrevistados neste estrato afirmaram não se preocupar com o assunto (contra $20 \%$ no outro estrato) e $10 \%$ disseram estar apenas um pouco preocupados com isso (contra $3 \%$ entre os indivíduos que não trabalham).

A renda per capita também parece exercer influência sobre o padrão de resposta dos indivíduos entrevistados. Os indivíduos das faixas de renda menor e intermediária parecem menos preocupados com a ingestão de resíduos químicos decorrente do consumo de frutas, uma vez que $27 \%$ dos entrevistados afirmaram não se preocupar com o assunto, em ambos os estratos (contra $15 \%$ na faixa de maior renda). 


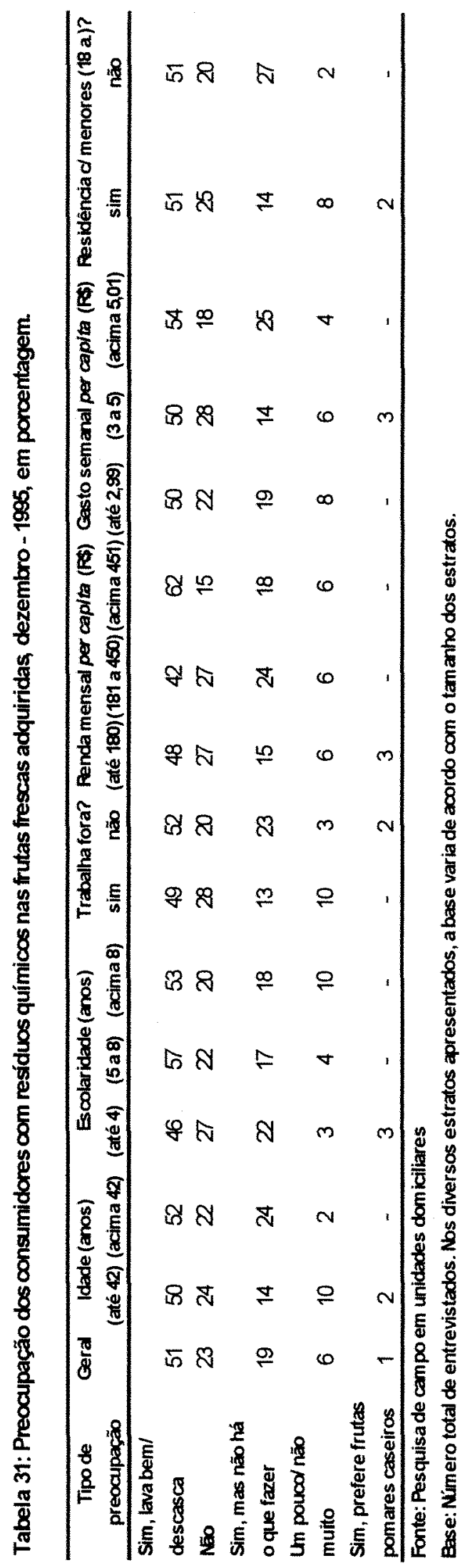


Em relação ao gasto per capita, os entrevistados pertencentes à faixa de maior gasto semanal com frutas parecem estar um pouco mais preocupados com a ingestão de resíduos químicos, uma vez que apenas $18 \%$ destes indivíduos disseram não se preocupar com o assunto (contra $22 \%$ na faixa de menos gasto e $28 \%$ na intermediária). Além disso, o número de indivíduos que se afirmou apenas um pouco preocupado também foi menor nesta faixa ( $4 \%$ dos entrevistados, contra $6 \%$ na faixa intermediária e $8 \%$ na de menor gasto).

Finalmente, um pouco diferente do resultado esperado, os individuos das unidades domiciliares com menores de 18 anos parecem menos preocupados com resíduos químicos, pois $25 \%$ disseram não se preocupar com o assunto (contra $20 \%$ nas unidades domiciliares só com adultos) e $8 \%$ dizem estar apenas um pouco preocupados (contra $2 \%$ no outro estrato).

O consumo de produtos orgânicos ${ }^{31}$ também foi analisado nas entrevistas. Os resultados apresentados foram, de certa forma, surpreendentes, uma vez que $51 \%$ dos entrevistados afirmaram já terem consumido produtos orgânicos, como pode ser observado na Tabela 32.

O consumo de produtos orgânicos aumentou no estrato de idade mais elevada, com $62 \%$ dos entrevistados afirmando já ter consumido este tipo de produto (contra $40 \%$ no outro estrato).

\footnotetext{
${ }^{31}$ Produto orgânico, foi definido, nesta pesquisa, como aquele produzido sem 0 uso de produtos e adubos químicos.
} 


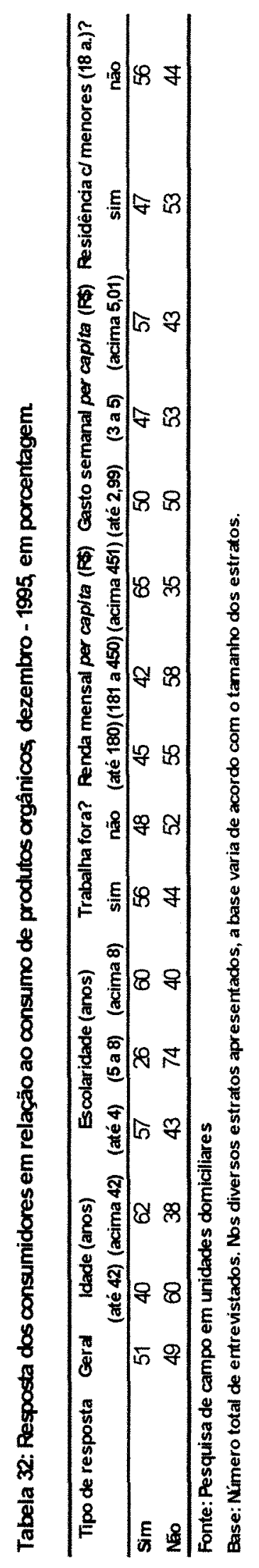


A escolaridade também parece afetar o padrão de respostas, com uma porcentagem maior de indivíduos já tendo consumido produtos orgânicos na faixa de maior escolaridade ( $60 \%$ dos entrevistados), seguida da faixa de menor escolaridade ( $57 \%$ dos entrevistados), com a faixa intermediária apresentando a menor porcentagem (apenas 26\%).

Os indivíduos entrevistados que trabalham fora declararam já ter consumido mais produtos orgânicos que os indivíduos que não trabalham (56\%, contra apenas $48 \%$ ).

Em relação à renda per capita, a faixa de maior renda, conforme esperado, revelou já ter consumido produtos orgânicos com uma frequêencia maior relativamente a outras faixas de renda $(65 \%$ dos entrevistados afirmaram já ter consumido produtos orgânicos). O estrato de menor renda vem em seguida, com $45 \%$ dos entrevistados afirmando já ter consumido este tipo de produto. Finalmente, temos o estrato de renda intermediária, com $42 \%$ dos entrevistados já tendo consumido este tipo de produto.

O gasto semanal per capita com frutas parece influenciar o padrão de resposta no mesmo sentido da renda, uma vez que $57 \%$ dos entrevistados do estrato de maior gasto semanal afirmaram já ter consumido produtos orgânicos, contra $50 \%$ no estrato de menor gasto e $47 \%$ no intermediário.

Finalmente, em relação ao fato da unidade domiciliar possuir ou não indivíduos menores de idade, tem-se uma porcentagem maior de indivíduos que declarou já ter consumido produtos orgânicos entre os entrevistados das residências somente habitadas por indivíduos adultos $(56 \%$, contra $47 \%$ nas unidades com indivíduos menores de 18 anos).

É interessante ressaltar que, conforme pode-se observar na Tabela 33, o motivo apresentado pelos entrevistados para o não consumo de produtos orgânicos está 
relacionado à indisponibilidade do produto no mercado. Este padrão de resposta, de maneira geral, não variou muito com a estratificação.

Já para os indivíduos que declararam já ter consumido produto orgânico, o principal motivo de consumo está relacionado à presença de pomar próprio, não tratado com produtos químicos (Tabela 34). Este padrão de resposta também não variou muito com a estratificação. Isso pode vir a explicar o alto consumo deste tipo de produto, que não era esperado na pesquisa.

Em relação ao conjunto evocado para o item frutas, foi feita uma análise em três níveis. Em um primeiro momento, foi analisada a preferência dos entrevistados pelos diversos tipos de frutas. Em segundo lugar, analisou-se os tipos de frutas comprados pelos entrevistados. Finalmente, foi analisada a rejeição por algum ou mais tipo de fruta.

Conforme pode ser observado na Tabela 35, ao analisar-se o resultado da pesquisa como um todo, as frutas preferidas pelos consumidores entrevistados foram, em primeiro lugar a laranja, seguida da melancia, com a banana na terceira posição. A Tabela 35 também mostra uma grande variação da classificação dos tipos de frutas devido à estratificação. No entanto, seria perigoso tentar tirar conclusões a respeito da classificação dos tipos de frutas por estratos, com base nos dados desta pesquisa.

É importante ressaltar que, nessa tabela, os dados foram apresentados através de uma pontuação. Esta pontuação com ponderação é apresentada todas as vezes que o entrevistado teve que ordenar ou classificar os itens da questão de acordo com determinado critério (como preferência, grau de confiança ou importância). 

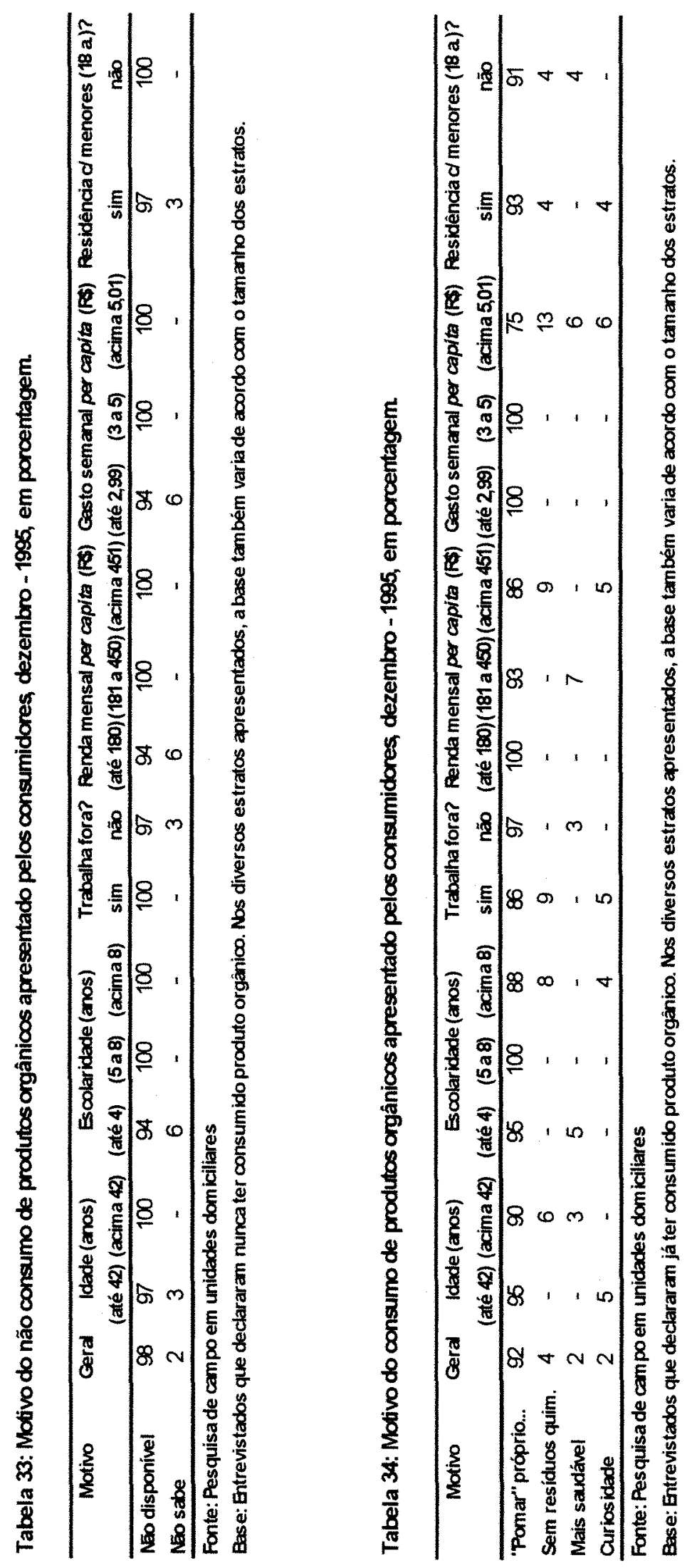


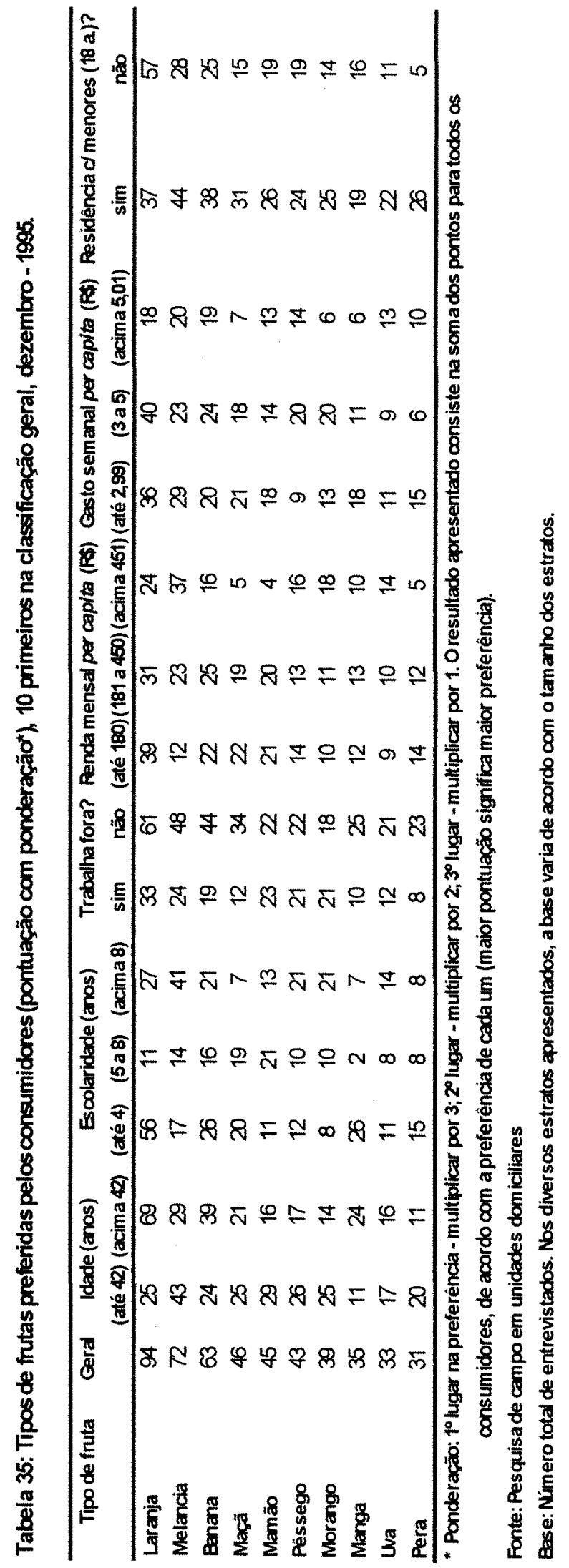


Em relação às frutas efetivamente compradas pelos consumidores entrevistados, tem-se um resultado provavelmente mais conclusivo, devido à maior concentração dos resultados, conforme pode ser observado na Tabela 36. A fruta mais comprada foi a laranja, seguida da banana, com a maçã na terceira colocação. Ao realizar-se a estratificação não houve variação significativa no padrão de respostas.

Quando foi analisada a rejeição de um ou mais tipos de frutas, notou-se que a maioria dos entrevistados rejeita algum(s) tipo(s) de fruta(s) (72\%), ocorrendo também pequena variação quando realiza-se a estratificação, conforme pode ser observado na Tabela 37.

Uma vez ocorrendo a rejeição, fica dificil estabelecer uma classificação conclusiva, devido à distribuição equilibrada das citações entre os diversos tipos de frutas rejeitados (Tabela 38), o mesmo ocorrendo quando se realiza a estratificação.

Após a análise das influências externas e internas tem-se, como último componente da fase de pré-compra, o processo de tomada de decisão. De acordo com o modelo proposto, este processo foi dividido em três estágios: reconhecimento do problema, busca de informações e avaliação das alternativas.

Com o objetivo de tentar delinear o estágio de reconhecimento do problema, foi feita uma análise das maneiras de consumo de frutas. Conforme pode ser observado na Tabela 39, de maneira geral, os entrevistados consumiram o produto principalmente na forma original, in natura. Em um segundo momento, ocorreu o consumo do produto na forma de suco. Finalmente, o produto também foi consumido como ingrediente de outros pratos. Este padrão de resposta foi o mesmo em todos os estratos analisados. 

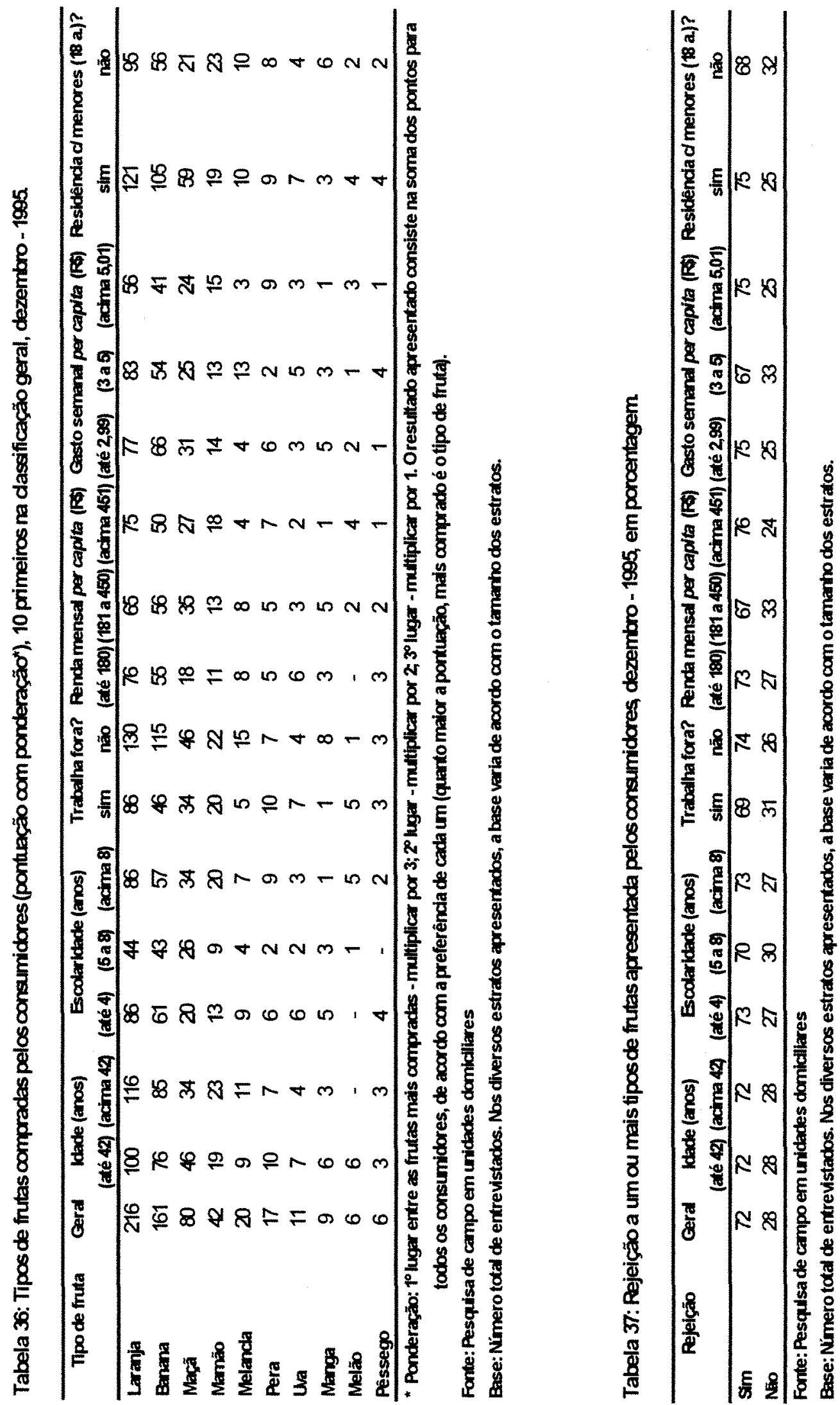

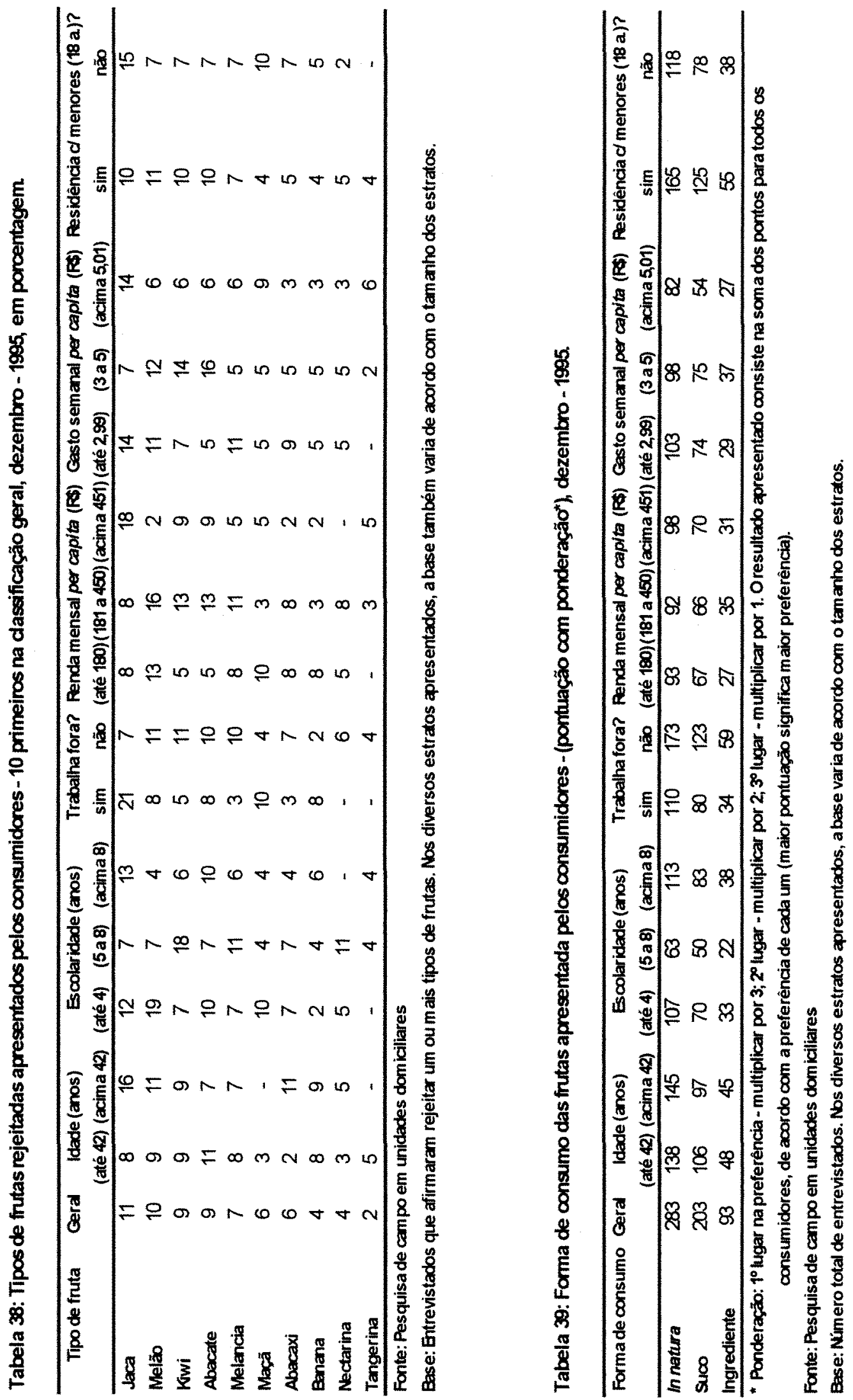
Todos os indivíduos entrevistados afirmaram consumir o produto in natura. Quando consultados sobre o tipo de fruta mais adequado para consumo desta forma, teve-se, considerando a amostra como um todo, a banana e a laranja como sendo as frutas mais adequadas, com a mesma porcentagem. Em segundo lugar, encontrou-se a maçã. Ao analisar-se o resultado por estratos, ocorreram algumas variações na ordem de classificação, mas estes três tipos de frutas foram sempre considerados os mais adequados, conforme pode ser observado na Tabela 40 .

O uso de frutas como ingrediente já não foi tão unânime, pois apenas $84 \%$ dos entrevistados afirmaram consumir o produto desta maneira, conforme pode ser observado na Tabela 41 .

Em relação aos tipos de frutas considerados mais adequados para consumo como ingrediente, teve-se, considerando a amostra como um todo, a banana como sendo a fruta mais adequada. Em segundo lugar, encontraram-se a maçã e a laranja, com a mesma porcentagem. Ao analisar-se o resultado por estratos, ocorreram algumas variações na ordem de classificação, mas estes três tipos de frutas também foram sempre considerados os mais adequados, conforme pode ser observado na Tabela 42 .

As frutas também foram consumidas na forma de suco por $97 \%$ dos entrevistados, conforme pode ser observado na Tabela 43, ocorrendo pequenas variações quando realiza-se a estratificação.

O tipo de fruta preferido para consumo na forma de suco foi a laranja, seguida do maracujá, do limão e do abacaxi, não existindo porém diferença grande entre estes três últimos tipos. Ao realizar-se a estratificação, a laranja permaneceu como tipo preferido em todos os estratos, no entanto, as outras posições sofreram algumas alterações na ordem de classificação, conforme pode ser observado na Tabela 44 . 

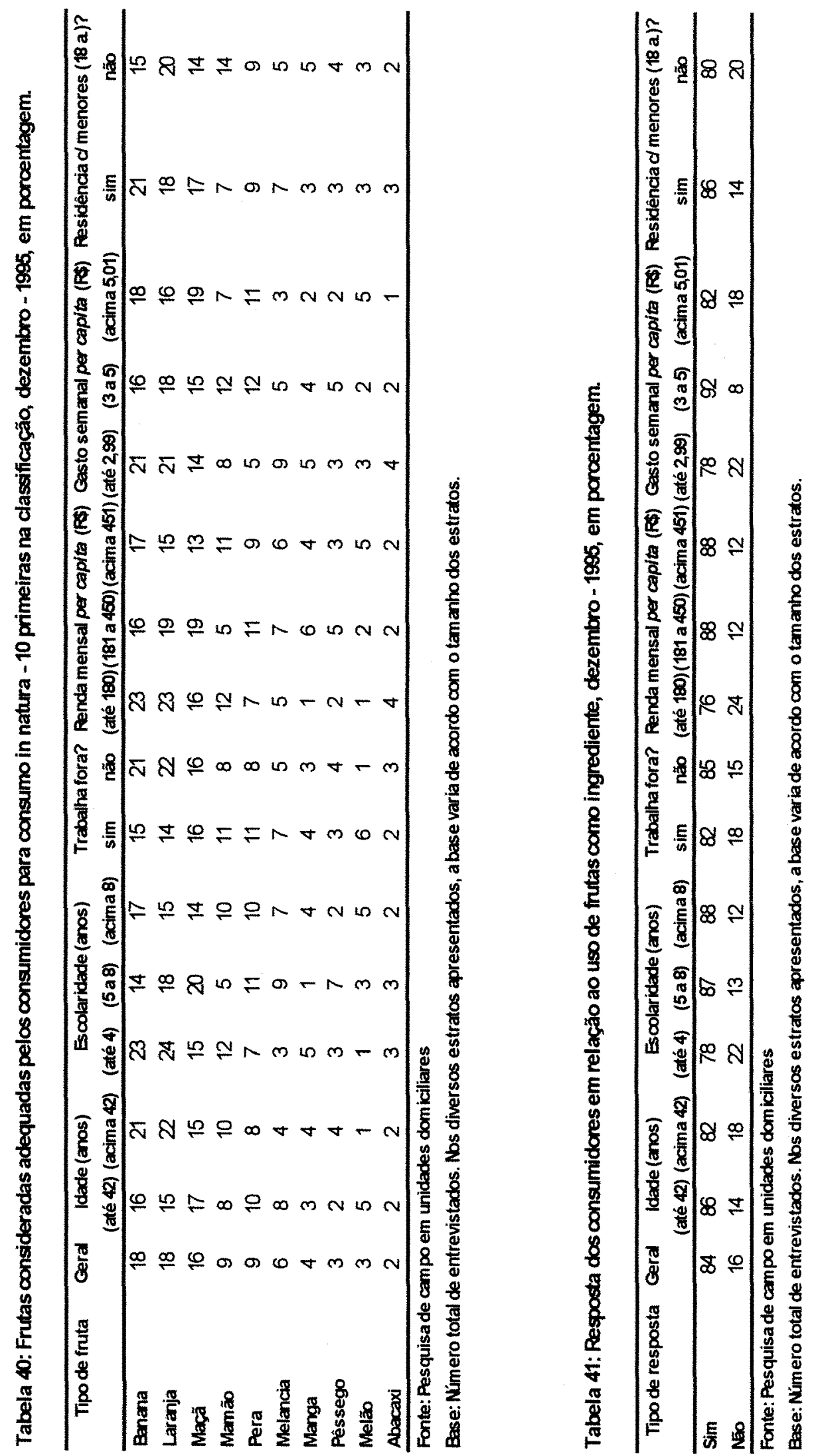

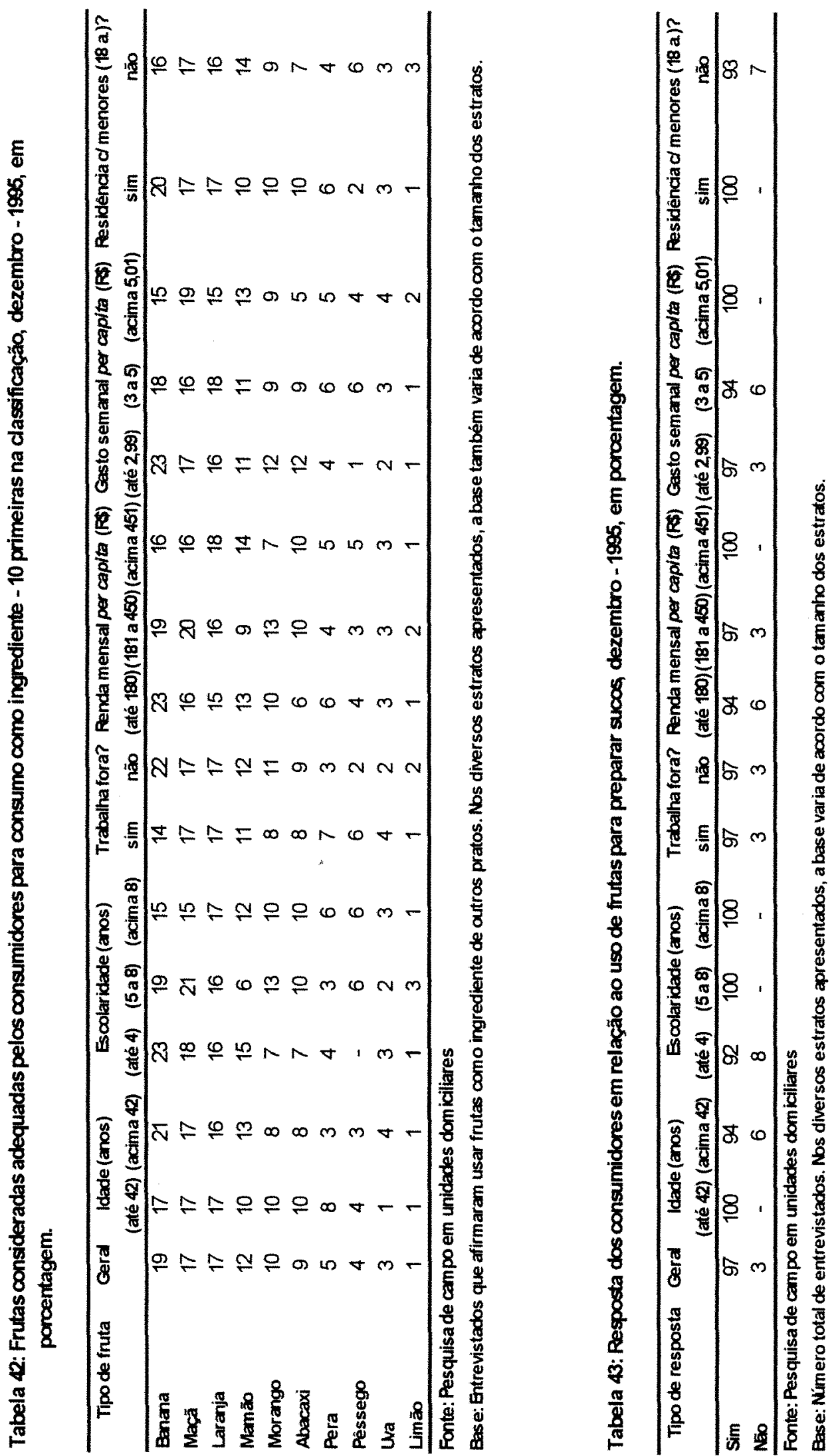


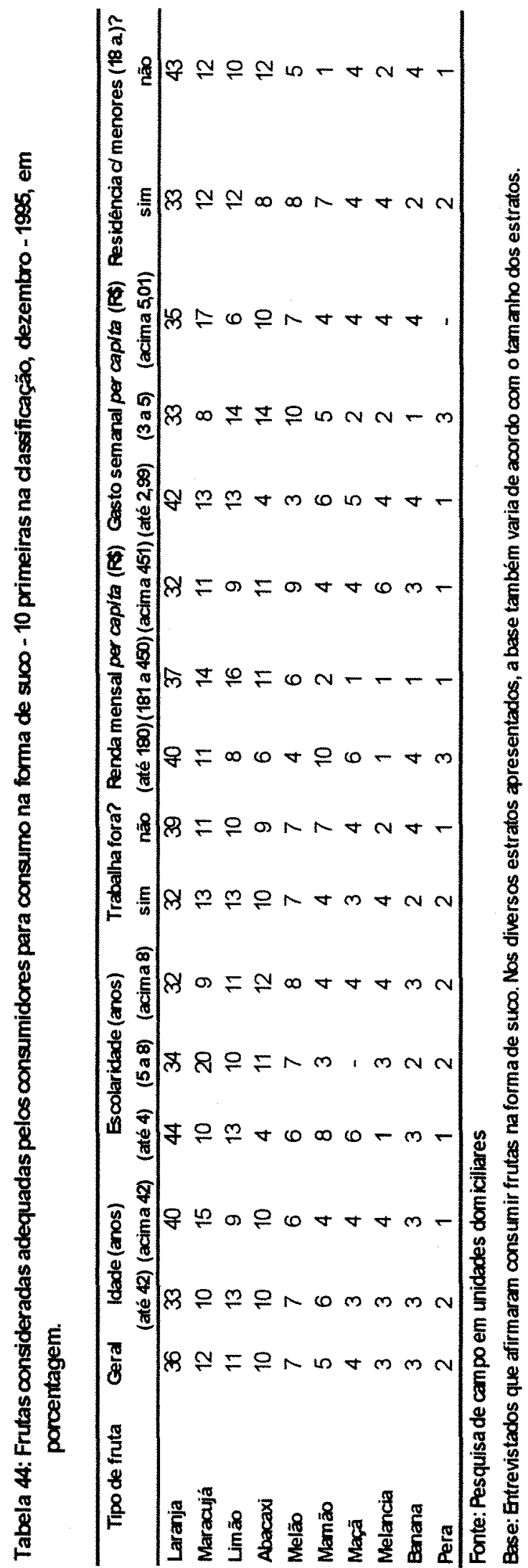


Para complementar a análise do reconhecimento da necessidade, também foi verificado se os individuos entrevistados escolhem o tipo de fruta pensando no uso que a mesma terá. Conforme pode ser observado na Tabela 45, a maioria dos entrevistados $(77 \%)$ não escolhe o tipo de fruta pensando no uso.

Analisando o resultado por estrato, verifica-se que a idade tem pequena influência no padrão de resposta. A escolaridade, por sua vez, altera os padrões de resposta, com os individuos de maior escolaridade não escolhendo o tipo de fruta de acordo com o uso com maior frequência ( $83 \%$ dos entrevistados com escolaridade acima de 8 anos, $78 \%$ na faixa intermediária e $70 \%$ na faixa de menor escolaridade).

O fato dos indivíduos entrevistados trabalharem ou não fora da unidade domiciliar também parece interferir no padrão de resposta. Os indivíduos que trabalham fora parecem menos preocupados com a escolha do tipo de fruta de acordo com o uso, uma vez que $85 \%$ dos entrevistados neste estrato disseram não escolher as frutas de acordo com o uso (contra $72 \%$ no outro estrato).

A renda e o gasto semanal per capita também parecem alterar o padrão de resposta. Em ambos os casos, ocorreu um aumento da porcentagem de indivíduos menos preocupados com a escolha do tipo de fruta de acordo com o uso, conforme aumenta a renda ou gasto.

Finalmente, verificou-se também que as unidades domiciliares com indivíduos menores parecem menos preocupadas com a escolha do tipo de fruta de acordo com o uso pretendido. 


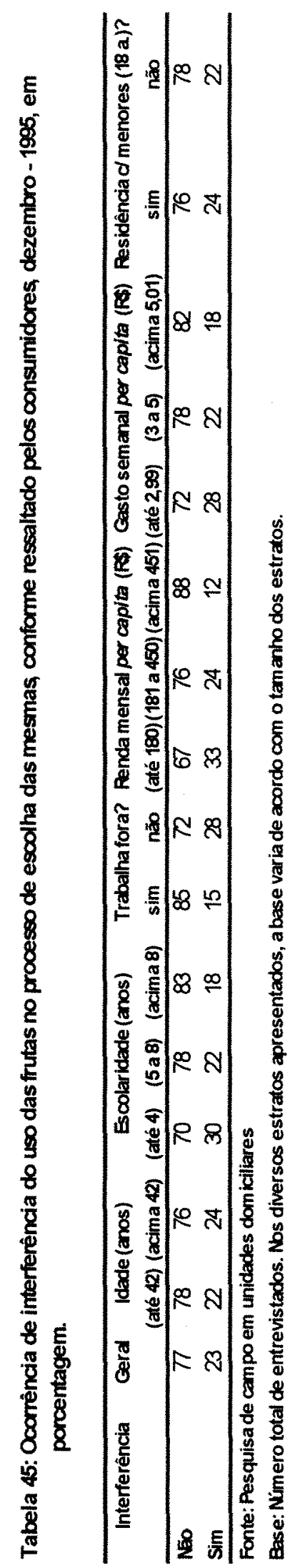


Em relação à busca de informações sobre frutas, avaliou-se, nesta pesquisa, a confiança dos entrevistados em relação a vários tipos de fontes de informação, comerciais ou não. Neste sentido, conforme pode ser observado na Tabela 46 , teve-se a seguinte classificação (em ordem decrescente de confiança): médico da família, nutricionista, livros, clínicas, escolas, amigos e família, programas de TV, governo, artigos de revista, artigos de jornal, comentários de rádio, propagandas na TV, propagandas em jornal, propagandas em revistas e propagandas no rádio. Quando os resultados por estratos são analisados, nota-se algumas variações no padrão de classificação.

Para finalizar a fase de pré-compra, o consumidor vai avaliar as alternativas a sua disposição. Nesta fase, considera-se que a avaliação será feita com base nos atributos do produto. Assim sendo, foi feito um levantamento da importância de cada atributo para os indivíduos entrevistados, com a classificação dos atributos segundo sua importância, conforme pode ser observado na Tabela 47.

Conforme pode ser observado, a classificação dos atributos, em ordem decrescente de importância, foi: frescor, saudável, firmeza, sabor, segurança, aparência, cor, valor nutritivo, preço, selo de qualidade, variedade/ tipo, efeito ambiental da produção, local de produção, embalagem, tamanho e marca. Embora ocorram algumas variações no padrão de classificação quando os resultados são estratificados, estas variações na pontuação não permitem que se chegue a nenhum resultado conclusivo. 


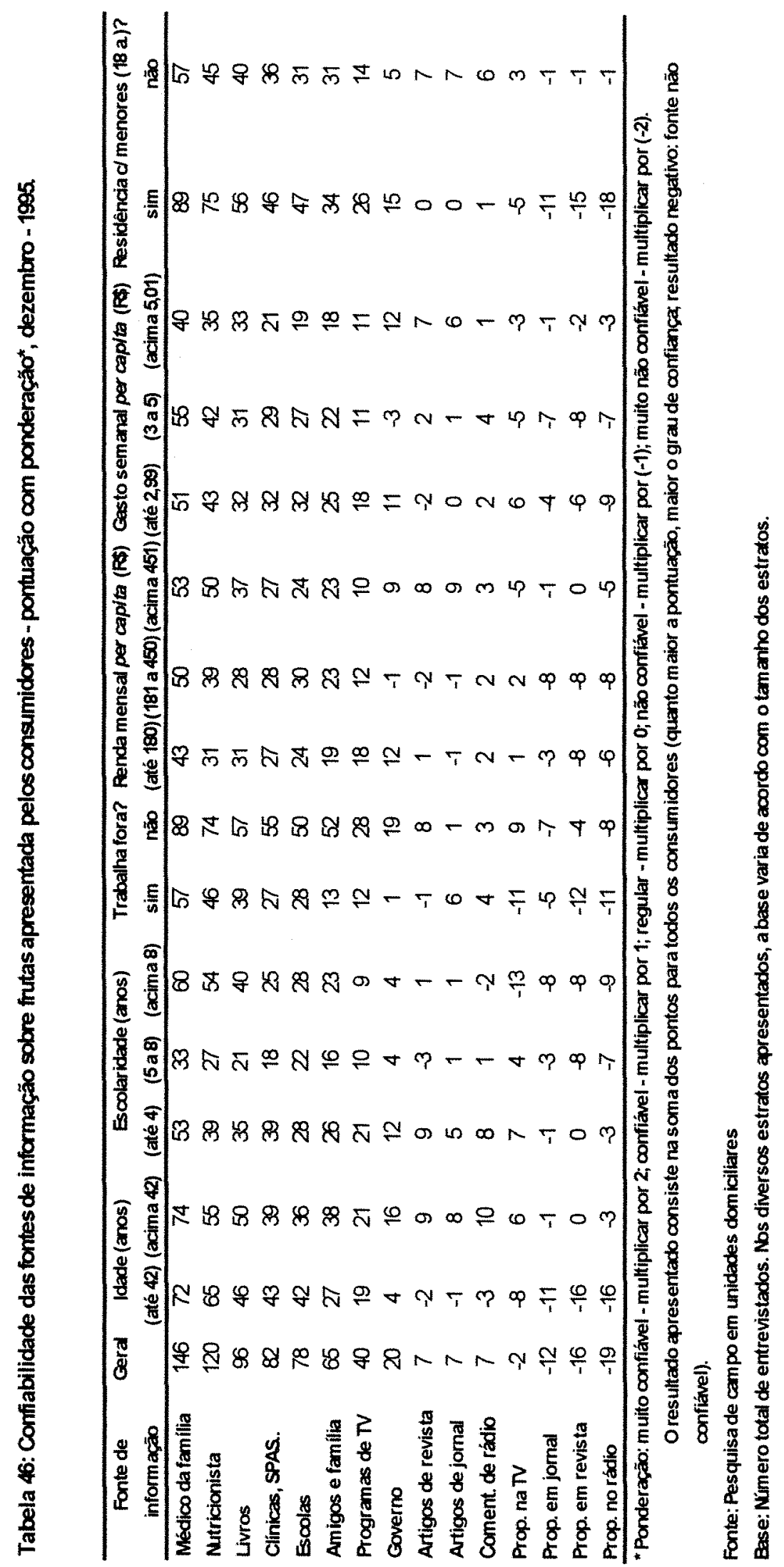




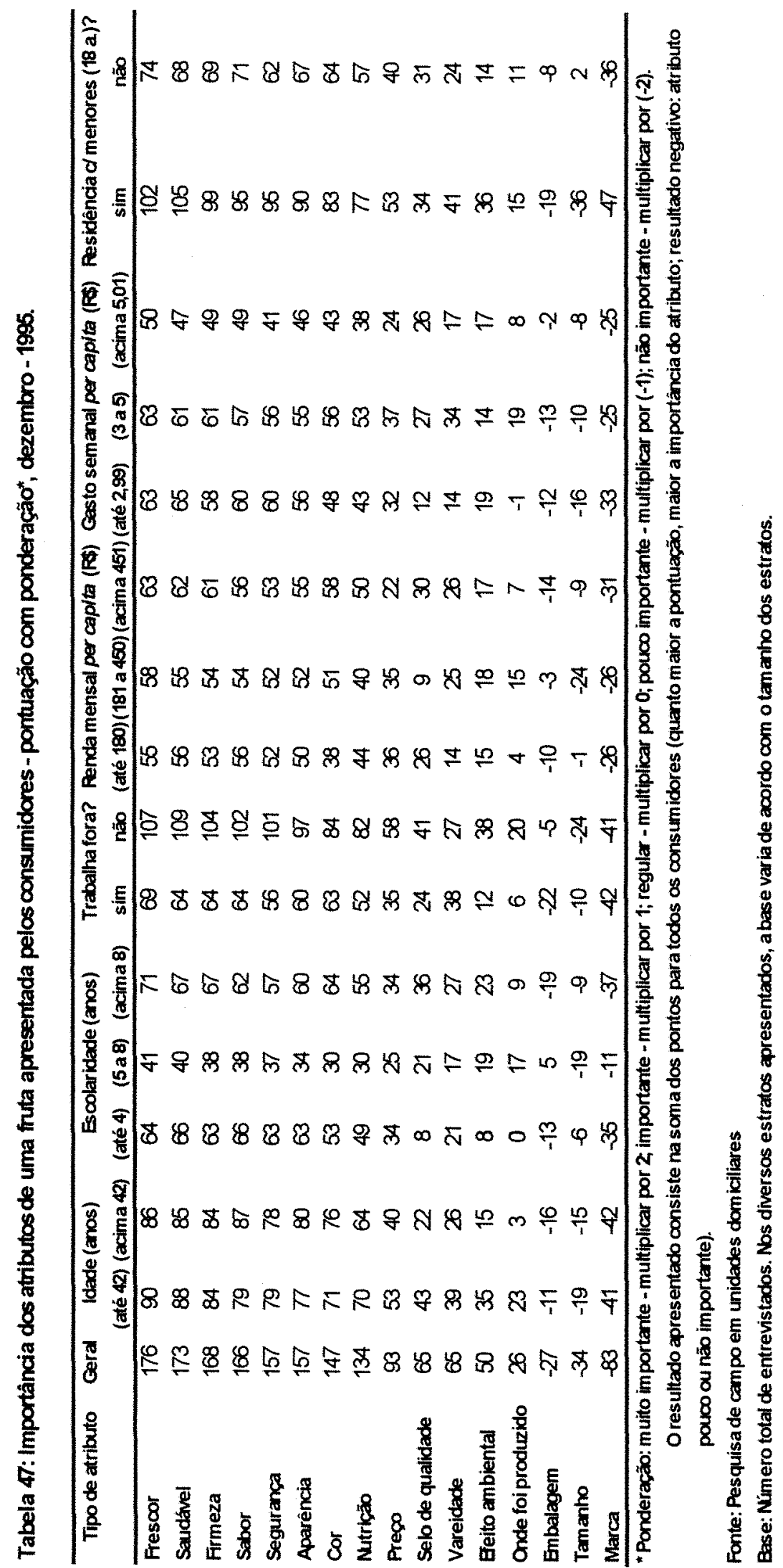




\subsection{Compra}

Os tipos de frutas efetivamente comprados já foram discutidos anteriormente (ver Tabela 36). Assim sendo, a discussão da fase de compra foi centrada, seguindo o modelo proposto, em três aspectos: situação de compra, local de aquisição e atores no processo de compra.

A situação onde ocorre a compra é composta por vários elementos. Entre eles, destacam-se: ambiente de informação, ambiente de ponto de venda e influência temporal.

Para avaliar o ambiente de informação, nesta pesquisa, foram avaliados os tipos de informação que os entrevistados gostariam de ter disponíveis no momento da compra, relacionados ao item frutas (Tabela 48 ).

Conforme pode ser observado na Tabela 48, os principais tipos de respostas, considerando a amostra como um todo, foram: nenhuma informação a mais (19\% das menções), produtos químicos presentes $(14 \%)$, procedência do produto $(14 \%)$, data de colheita/ validade $(13 \%)$ e teores de vitaminas $(12 \%)$.

Analisando os resultados por estratos, percebe-se que a idade do entrevistado interfere principalmente no fato do indivíduo desejar ou não algum tipo de informação adicional. Neste sentido, pode-se perceber que os indivíduos mais idosos parecem ter uma tendência de estar satisfeitos com menor número de informações no ambiente de venda, uma vez que $26 \%$ dos entrevistados neste estrato afirmaram não desejar qualquer tipo de informação adicional sobre as frutas que adquirem (contra apenas $12 \%$ no outro estrato). 
136

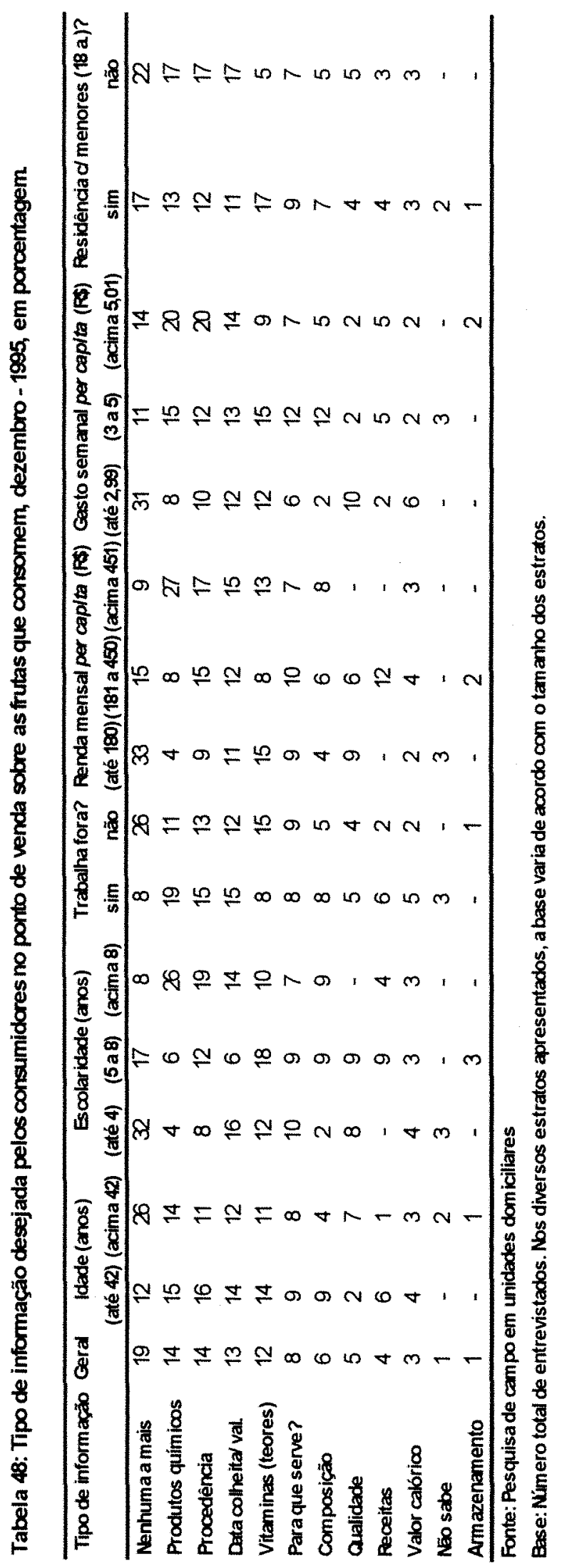


A escolaridade também parece afetar o padrão de resposta. Os indivíduos com maior grau de escolaridade parecem estar mais preocupados com receber informações adicionais sobre as frutas, uma vez que apenas $8 \%$ dos entrevistados da faixa de maior grau de escolaridade não deseja qualquer tipo de informação adicional sobre as frutas adquiridas (contra $17 \%$ na faixa intermediária e $32 \%$ na faixa com menor grau de escolaridade). Isso também se evidencia pela preocupação com informações a respeito de produtos químicos e procedência dos produtos, onde teve-se, respectivamente, $26 \%$ e 19\% dos indivíduos desejando ter informações adicionais sobre estes aspectos, na faixa de maior grau de escolaridade (contra $6 \%$ e $12 \%$ na faixa intermediária e $4 \%$ e $8 \%$ na faixa de menor grau de escolaridade)

Os indivíduos que trabalham fora também parecem mais preocupados com maior número de informações disponiveis no ponto de venda, uma vez que apenas $8 \%$ dos indivíduos neste estrato não desejam qualquer tipo de informação adicional sobre este aspecto, contra $26 \%$ entre os indivíduos que não trabalham fora.

A renda per capita também parece influenciar o padrão de reposta. Indivíduos com maior renda apresentaram uma tendência de desejar maior número de informações adicionais. Isso se evidencia pelo fato de apenas $9 \%$ dos entrevistados da faixa de maior renda dizerem não desejar qualquer tipo de informação adicional, contra $15 \%$ na faixa intermediária e $33 \%$ no estrato de menor renda.

O gasto semanal per capita com frutas também parece apresentar uma tendência de influência sobre o padrão de resposta. De maneira geral, parece haver uma tendência de maior número desejado de informações conforme o gasto aumenta, uma vez que apenas $14 \%$ dos entrevistados da faixa de maior gasto e $11 \%$ dos entrevistados da faixa intermediária não desejam qualquer tipo de informação adicional, contra $31 \%$ na faixa de menor gasto. 
Finalmente, o fato de haver ou não individuos menores na unidade domiciliar também parece influenciar os padrões de resposta. Os entrevistados de residências onde existem indivíduos menores parecem estar mais preocupados em receber informações adicionais sobre as frutas adquiridas, no ponto de venda. Isso pode ser evidenciado pelo fato de $17 \%$ dos entrevistados nesta faixa não desejarem qualquer tipo de informação adicional, contra $22 \%$ nas residências somente com adultos.

O segundo elemento da situação de compra, ambiente do ponto de venda, também pode influenciar o consumo de frutas. Desta maneira, foram levantados os fatores considerados mais importantes neste ambiente, com posterior classificação dos mesmos, de acordo com a sua importância para os entrevistados, conforme pode ser observado na Tabela 49.

Conforme pode ser observado, o fator mais importante para os entrevistados, em relação ao ambiente do ponto de venda, foi a limpeza. Em seguida teve-se, em ordem decrescente de importância: apresentação dos produtos, ausência de odores, espaço para circulação, sistema de pesagem e vendedores. Ao realizar-se a estratificação, ocorreram pequenas modificações no padrão de resposta.

A situação de compra envolve, por fim, a influência temporal. Neste sentido, são destacadas duas dimensões importantes: tempo disponível e época do ano/ sazonalidade.

A influência do tempo disponível sobre a compra de frutas, para a amostra pesquisada, pode ser observada na Tabela 50. De maneira geral, o tempo disponível parece não afetar o processo de escolha/ compra de frutas, uma vez que $63 \%$ dos entrevistados afirmaram não ser afetados pelo tempo no processo de compra. Os motivos apresentados para a não influência consistiram em somente realizar esta tarefa quando tiver tempo suficiente para tal ou prática para executar esta atividade, não atrapalhando o desempenho. 

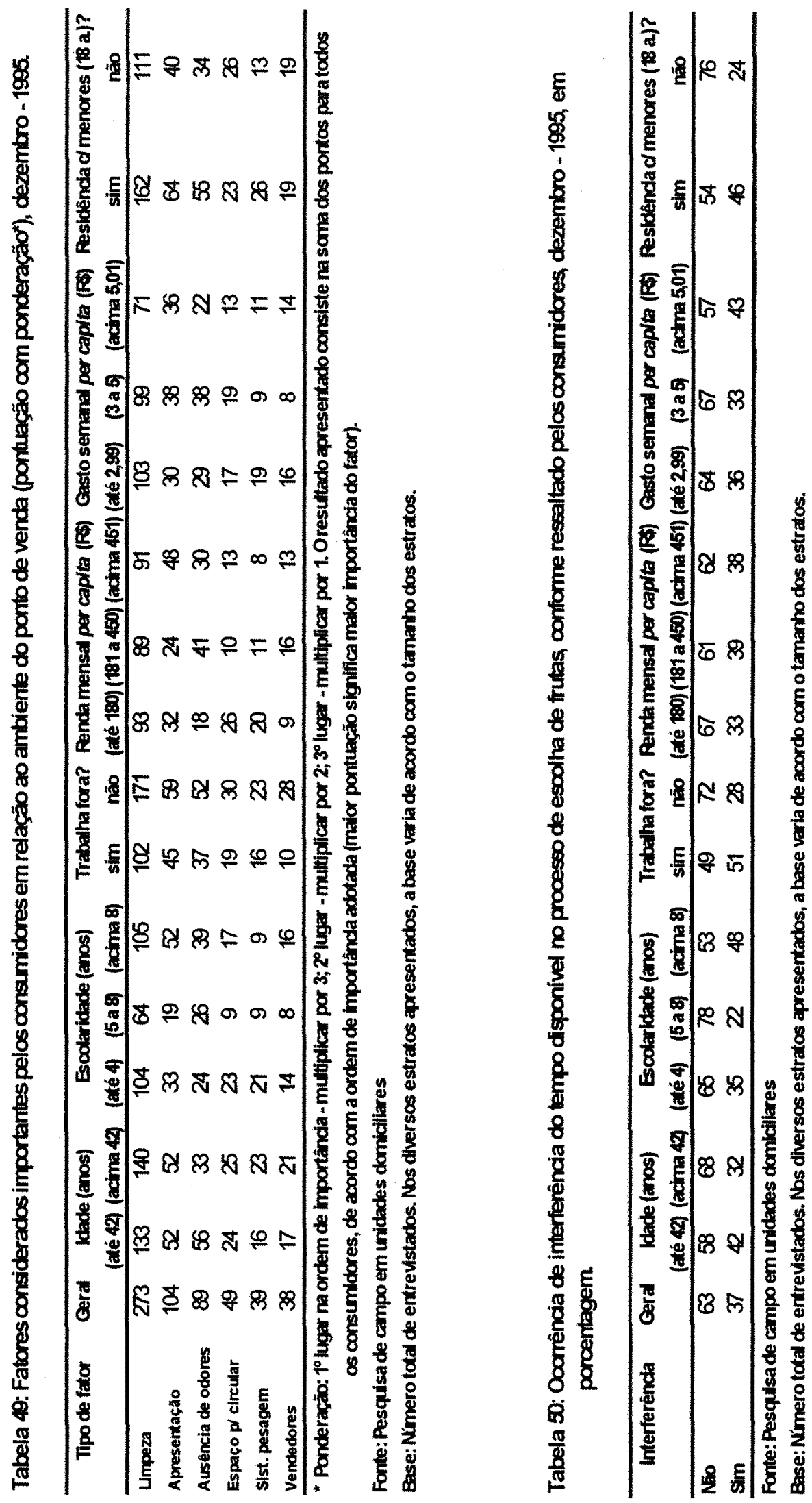
Quando realiza-se a estratificação, nota-se que ocorrem algumas alterações no padrão de respostas. Os indivíduos mais idosos parecem ser menos influenciados pelo tempo disponível, pois $68 \%$ dos entrevistados nesta faixa disseram não sofrer influência do tempo disponivel no processo de compra, contra $58 \%$ no outro estrato. A explicação para esta variação pode estar relacionada à menor pressão temporal sobre os indivíduos mais velhos.

A escolaridade também parece alterar os padrões de resposta. Os indivíduos da faixa intermediária de escolaridade parecem menos influenciados pelo tempo disponível no processo de escolha, uma vez que $78 \%$ dos entrevistados nesta faixa afirmaram que $o$ tempo disponível não afeta o processo de escolha, contra $65 \%$ na faixa de menor escolaridade e apenas $53 \%$ na faixa de maior escolaridade.

Conforme esperado, o fato do indivíduo trabalhar fora interferiu de forma enfática no processo de escolha. Os individuos que trabalham fora sofrem maior influência do tempo disponível no processo de escolha (apenas $49 \%$ dos indivíduos entrevistados afirmaram não sofrer influência do tempo disponivel sobre o processo de escolha, contra $72 \%$ para os indivíduos que não trabalham fora).

Em relação à renda per capita, os indivíduos com maior renda parecem apresentar uma tendência a sofrer influência mais acentuada do tempo disponível. Podese comprovar esta tendência pelo fato de $62 \%$ dos indivíduos da faixa de renda mais alta e $61 \%$ da faixa intermediária afirmarem não sofrer influência do tempo disponivel, contra $67 \%$ na faixa de renda mais baixa.

O gasto semanal per capita com frutas também parece influenciar os padrões de resposta. Os indivíduos da faixa de maior gasto apresentaram uma influência maior do tempo no processo de escolha, com apenas $57 \%$ dos entrevistados afirmando não ser 
influenciados pelo tempo, contra $67 \%$ na faixa intermediária e $64 \%$ na faixa de menor gasto semanal.

Por fim, o fato de haver ou não indivíduos menores de 18 anos na unidade domiciliar também parece interferir no padrão de resposta. Conforme esperado, os indivíduos de unidades domiciliares com menores de 18 anos foram mais influenciados pelo tempo no processo de escolha de frutas, com apenas $54 \%$ dos indivíduos afirmando não ser influenciados pelo tempo, contra $76 \%$ na outra faixa.

Entre os indivíduos que disseram ser influenciados pelo tempo no processo de escolha foi feito um levantamento das conseqüências desta influência (Tabela 51). Conforme pode ser observado, a principal conseqüência foi não conseguir escolher bem os produtos (citado por $84 \%$ dos entrevistados que afirmaram sofrer influência do tempo). Em segundo lugar, os consumidores disseram limitar a escolha a alguns tipos básicos de frutas devido à pressão temporal (14\% dos entrevistados). A escolha de locais mais perto também apareceu como conseqüência da limitação temporal para $3 \%$ dos indivíduos.

Ao analisar-se os resultados estratificados, pode-se notar que, embora ocorram algumas variações, o padrão de resposta se mantêm relativamente constante, com manutenção da seqüência de importância nas consequeências apresentadas.

O fator sazonalidade/época do ano também foi avaliado nesta pesquisa. Para avaliar este item, foi verificado se os entrevistados costumam comprar frutas da estação (Tabela 52). Neste sentido, pode-se verificar que a maioria dos entrevistados costuma comprar frutas da estação ( $91 \%$ dos entrevistados afirmaram consumir este tipo de produto). Ao serem analisados os dados estratificados, pode-se notar que houve o predomínio de indivíduos com o costume de adquirir produtos de época em todos os estratos analisados. 

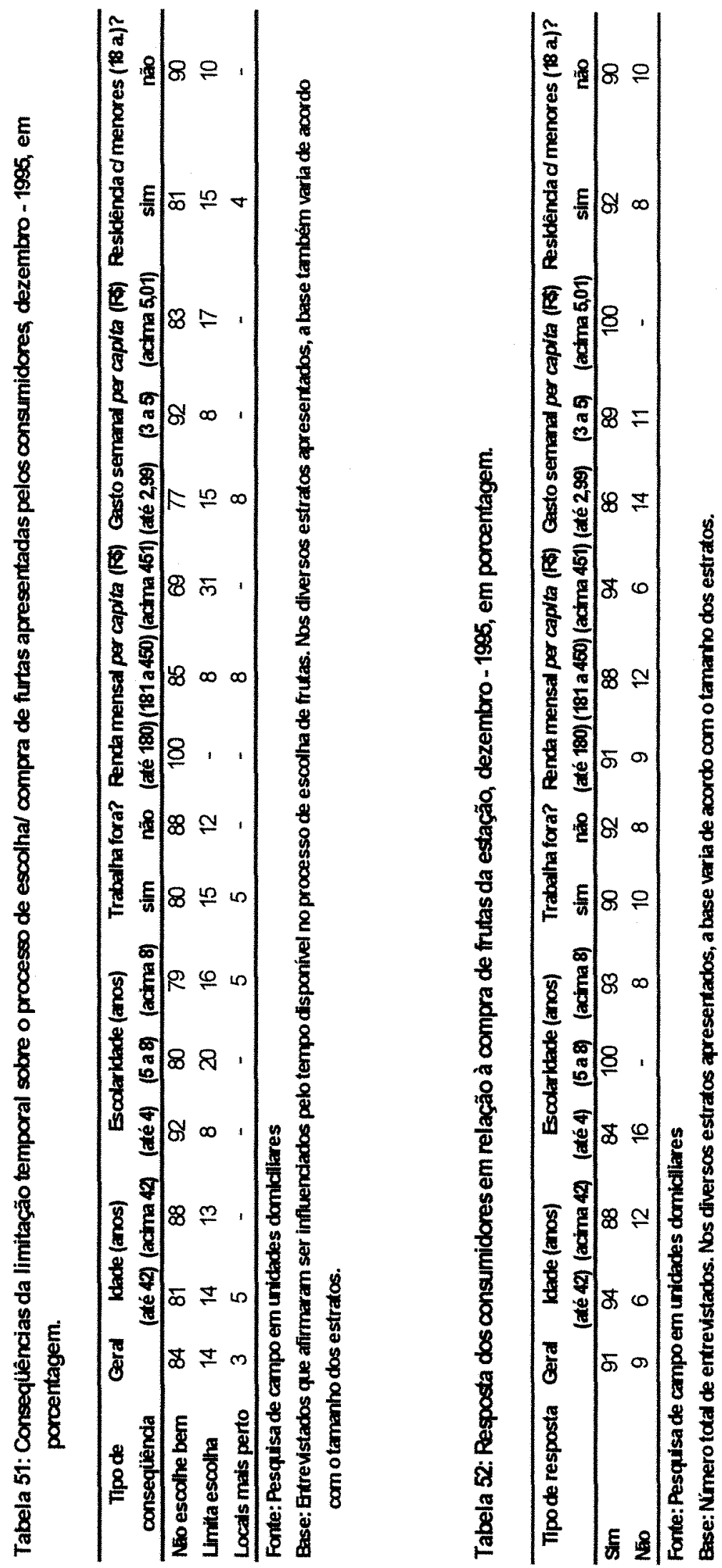
Para complementar a análise da sazonalidade, também foram investigados os motivos da opção pelo produto de época. Conforme pode ser verificado na Tabela 53, os motivos apresentados para a aquisição deste tipo de produto foram: preço (33\% dos entrevistados), qualidade (23\%), disponibilidade ( $21 \%$ ), produto mais fresco ( $8 \%$ ), sabor $(7 \%)$, produto mais saudável $(6 \%)$ e variar tipos de frutas $(2 \%)$.

Avaliando os resultados estratificados, em relação aos principais motivos de escolha, pode-se notar que ocorrem algumas alterações no padrão de resposta. Os indivíduos do estrato acima de 42 anos parecem estar mais motivados por preço e qualidade ao optarem pelo produto sazonal, pois o preço foi ressaltado como motivo por $39 \%$ dos entrevistados (contra $28 \%$ no outro estrato) e a qualidade por $30 \%$ (contra $18 \%$ entre os indivíduos até 42 anos). Já a disponibilidade foi mais citada como motivo de aquisição pelos indivíduos mais novos ( $29 \%$ dos entrevistados, contra apenas $11 \%$ na outra faixa).

Os indivíduos com menor grau de escolaridade parecem mais preocupados com a qualidade quando optam pelo produto de época, uma vez que $37 \%$ dos entrevistados com menor grau de escolaridade afirmaram ser este o motivo da opção (contra $16 \%$ na faixa intermediária e $18 \%$ na faixa de maior grau de escolaridade). O preço foi mais citado como motivo pelos indivíduos da faixa intermediária (38\% dos entrevistados, contra $34 \%$ na faixa de menor grau de escolaridade e $29 \%$ na de maior grau). A disponibilidade, por sua vez, foi considerada mais importante conforme o grau de escolaridade aumenta, uma vez que foi considerada motivo de consumo por $27 \%$ dos entrevistados na faixa de maior grau de escolaridade, $19 \%$ na faixa intermediária e $13 \%$ na faixa de menor grau de escolaridade. 
144

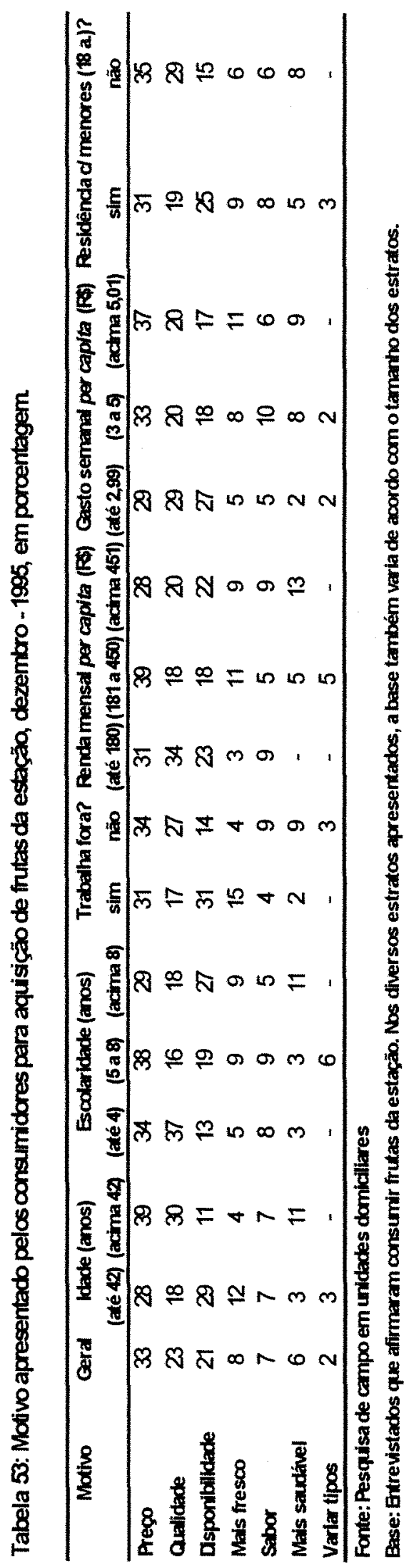


O fato do individuo entrevistado trabalhar fora ou não também parece interferir no padrão de resposta. Os indivíduos que não trabalham fora parecem mais preocupados com o preço e a qualidade quando optam por produtos de época (citados como motivos por $34 \%$ e $27 \%$ dos entrevistados, respectivamente, contra $31 \%$ e $17 \%$ entre os indivíduos que não trabalham). A disponibilidade, conforme esperado, foi mais citada como motivo entre os indivíduos que trabalham fora ( $31 \%$ dos entrevistados, contra $14 \%$ no outro estrato).

Em relação à renda per capita, os indivíduos de renda intermediária parecem mais preocupados com preço quando optam pelo produto sazonal (39\% dos entrevistados nesta faixa citaram o preço como motivo, contra $31 \%$ no estrato de menor renda e $28 \%$ no de maior renda). A qualidade parece ser mais importante para o indivíduo de menor renda ( $34 \%$ dos entrevistados, contra $18 \%$ na faixa intermediária e $20 \%$ na faixa de maior rena). A disponibilidade, por sua vez, apresentou menor variação quando se realiza a estratificação por nível de renda.

Os indivíduos com maior gasto semanal per capita com frutas parecem mais preocupados com o preço, ao adquirir o produto de época, uma vez que $37 \%$ dos entrevistados citaram o preço como motivo de aquisição, contra $33 \%$ na faixa de gasto intermediária e $29 \%$ na faixa de menor gasto. A qualidade, por sua vez, apareceu como mais importante para os indivíduos com menor gasto semanal (29\% dos entrevistados, contra $20 \%$ nos outros dois estratos). A disponibilidade também apresentou maior importância para os indivíduos da faixa de menor gasto $(27 \%$ dos entrevistados, contra $18 \%$ na faixa intermediária e $17 \%$ na faixa de maior gasto).

O fato de haver indivíduos menores de 18 anos na unidade domiciliar também parece afetar os resultados. Os entrevistados de unidades domiciliares somente com adultos indicaram estar mais preocupados com prę̧o e qualidade (citados como motivo por $35 \%$ e $29 \%$ dos entrevistados, contra $31 \%$ e $19 \%$ nas residências com indivíduos 
menores). Já a disponibilidade foi mais citada como motivo pelos indivíduos das residências com indivíduos menores ( $25 \%$ dos entrevistados, contra $15 \%$ nas unidades domiciliares só com adultos).

O local de compra também é importante quando menciona-se a aquisição de frutas. Conforme pode ser observado na Tabela 54, a classificação dos locais de compra, em ordem decrescente de importância foi: sacolões/ varejões, supermercados, feiras, lojas de frutas, mercado municipal, vendedores ambulantes, direto do produtor, armazém, bar e Escola Superior de Agricultura Luiz de Queiroz - ESALQ.

Embora ocorram algumas variações, quando realiza-se a estratificação, a classificação não chega a se alterar de maneira significativa.

Os motivos da escolha do local de aquisição também foram avaliados para complementar a análise (Tabela 55). Os motivos apresentados, em ordem decrescente de importância, foram: variedade ( $23 \%$ dos entrevistados), praticidade/facilidade $(17 \%)$, produtos mais frescos $(17 \%)$, localização $(15 \%)$, preço $(12 \%)$, qualidade dos produtos $(7 \%)$, ambiente mais agradável $(4 \%)$, horário de funcionamento $(3 \%)$, costume $(2 \%)$ e confiança $(1 \%)$.

Analisando os resultados estratificados, em relação aos principais motivos de escolha apresentados pelos consumidores, têm-se algumas variações nos padrões de resposta. A idade parece interferir principalmente no que se refere a produtos mais frescos e preço. A citação de produtos mais frescos como motivo de escolha foi mais acentuada entre os indivíduos até 42 anos ( $23 \%$ dos entrevistados, contra $10 \%$ no outro estrato). O preço, por sua vez, foi considerado mais importante pelos indivíduos mais velhos (citado por $18 \%$ dos entrevistados, contra $7 \%$ na outra faixa). 

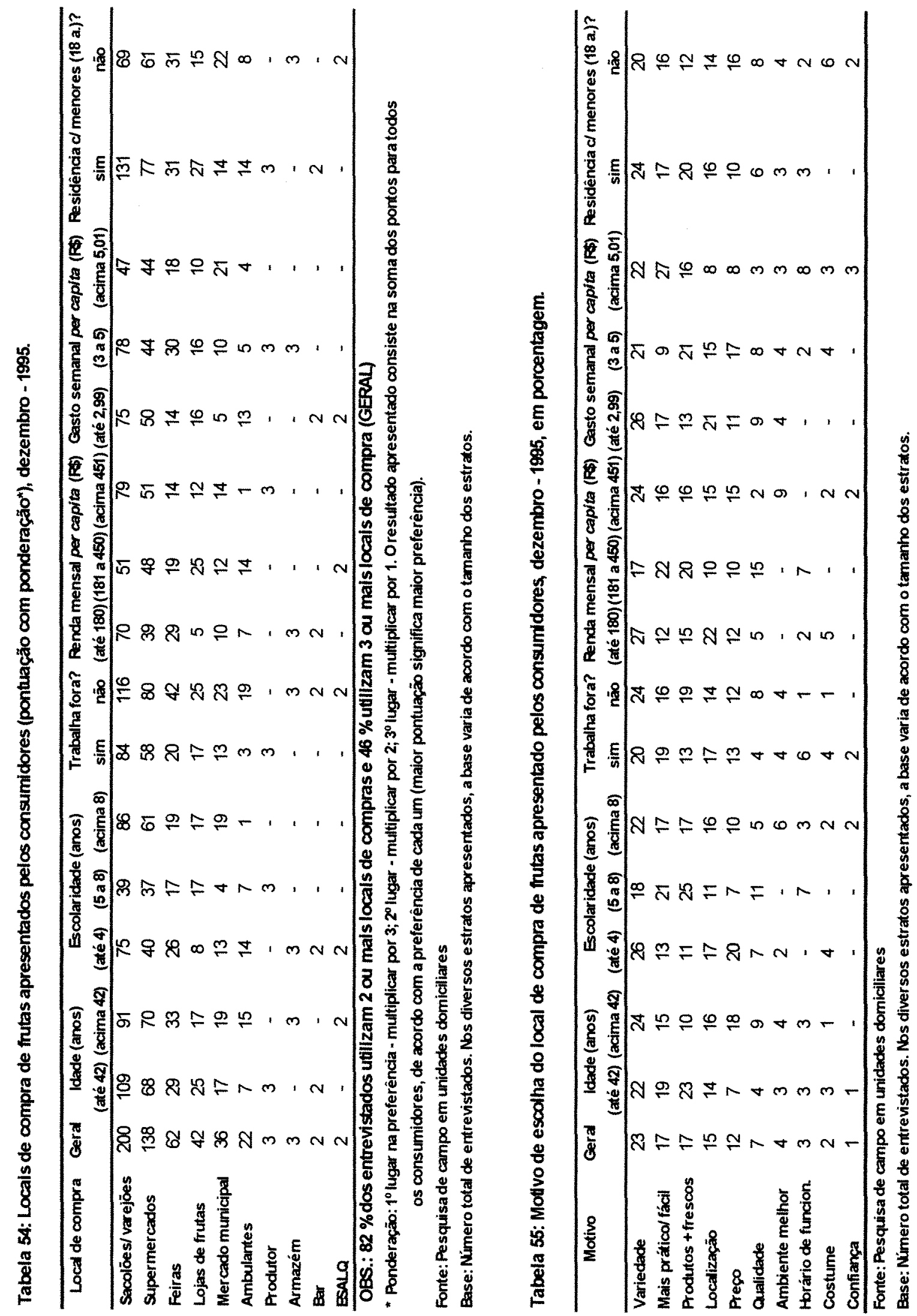
Em relação à escolaridade, o estrato de grau de escolaridade intermediário se destacou em relação aos motivos praticidade/ facilidade e produtos mais frescos, com $21 \%$ e $25 \%$ de citações, respectivamente, seguidos do estrato com maior grau de escolaridade, com $17 \%$ de citações, em ambos os casos, e do estrato com menor grau de escolaridade ( $13 \%$ e $11 \%$ das citações). A variedade e o preço foram considerados motivos de escolha mais importantes pelos indivíduos com menor escolaridade (26\% e $20 \%$ das citações, respectivamente), seguidos dos indivíduos da faixa de maior grau de escolaridade $(22 \%$ e $10 \%)$ e dos indivíduos da faixa intermediária $(18 \%$ e $7 \%)$. A localização, por sua vez, foi considerada um pouco mais importante para os indivíduos com menor escolaridade ( $17 \%$ das citações), seguida pela faixa de maior escolaridade $(16 \%)$ e da intermediária $(11 \%)$.

Conforme esperado, os individuos que trabalham fora estavam mais preocupados com os motivos praticidade/ facilidade e localização, ao escolherem o local de compra, quando comparados aos indivíduos que não trabalham fora de casa (citados por $19 \%$ e $17 \%$ dos entrevistados, respectivamente, contra $16 \%$ e $14 \%$ no outro estrato). Os indivíduos que não trabalham fora, por sua vez, estavam mais preocupados com variedade de produtos disponíveis e produtos mais frescos $(24 \%$ e $19 \%$ de citações, respectivamente, contra $20 \%$ e $13 \%$ entre os individuos que trabalham fora).

Em relação à renda per capita, as variações mais bruscas ocorrem em relação aos seguintes motivos de escolha: variedade, praticidade/ facilidade e localização. A variedade de produtos disponíveis e a localização do estabelecimento parecem ser mais importantes para a faixa de menor renda ( $27 \%$ e $22 \%$ das citações, respectivamente), seguida da faixa de maior renda ( $24 \%$ e $15 \%$, respectivamente) e da faixa intermediária $(17 \%$ e $10 \%)$. A praticidade/ facilidade, por sua vez, parece mais importante para a faixa de renda intermediária (22\%), seguida da faixa de maior renda $(16 \%)$ e da de menor renda (apenas $12 \%$ de citações). 
O gasto semanal per capita com frutas também parece interferir no padrão de resposta. A localização do estabelecimento parece ser mais importante para os indivíduos da faixa com menor gasto semanal (21\% dos entrevistados, contra $15 \%$ para os indivíduos da faixa intermediária e $8 \%$ para os indivíduos com maior gasto semanal). O preço parece mais importante para a faixa de gasto intermediária (17\%), seguida da faixa de menor gasto (11\%) e da de maior gasto $(8 \%)$. A disponibilidade de produtos mais frescos também parece ser mais importante para a faixa de gasto intermediária $(21 \%)$, seguida da faixa de maior gasto $(16 \%)$ e da de menor gasto (13\%). Finalmente, a praticidade parece ser mais importante para a faixa de maior gasto $(27 \%$ dos entrevistados), seguida da faixa de menos gasto (17\%) e da intermediária $(9 \%)$.

Para complementar a análise dos motivos de escolha por estrato, têm-se a estratificação pelo fato de haver ou não indivíduos menores de 18 anos na unidade domiciliar. Neste aspecto, as principais variações no padrão de resposta foram relativas a preço e disponibilidade de produtos mais frescos. O preço parece ser mais importante para as unidades domiciliares somente com adultos ( $16 \%$ dos entrevistados, contra $10 \%$ no outro estrato). Já a disponibilidade de produtos mais frescos parece ser mais importante para os entrevistados de unidades domiciliares com indivíduos menores $(20 \%$ dos entrevistados, contra $12 \%$ no outro estrato).

Para complementar a fase de compra, também foram avaliados os atores que atuam neste processo. Assim sendo, foi avaliado quem atua no processo de decisão e no de aquisição de frutas.

Conforme pode ser observado na Tabela 56, o entrevistado decidiu sobre as frutas a serem consumidas em $62 \%$ dos casos. Em $31 \%$ dos casos o entrevistado atuou em conjunto com outros membros da família no processo de decisão. Somente em $7 \%$ dos casos outros membros da família tomaram a decisão de consumo 


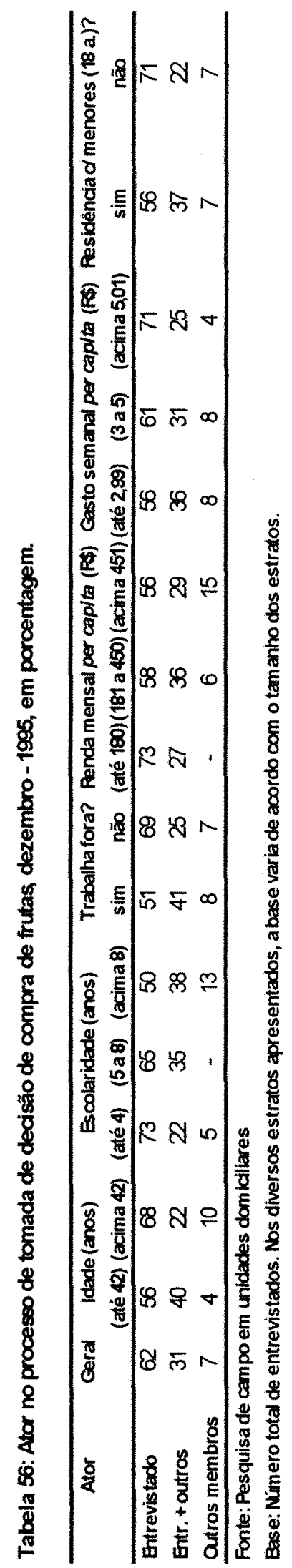


Em relação à estratificação, têm-se algumas alterações no padrão de respostas. O estrato de menor faixa etária parece ter a decisão de consumo de frutas mais distribuída entre o entrevistado e os outros membros da família, uma vez que o entrevistado toma a decisão de consumo, sozinho, em $56 \%$ dos casos (contra $68 \%$ entre os indivíduos acima de 42 anos).

Em relação à escolaridade, os indivíduos entrevistados com menor grau de escolaridade parecem estar mais envolvidos com o processo de decisão de consumo. Isso pode ser verificado pelo fato de $73 \%$ dos entrevistados da faixa com menor grau de escolaridade decidirem, sozinhos, sobre o consumo de frutas, seguidos da faixa intermediária, onde $65 \%$ dos entrevistados decidem sozinhos, e pela faixa com maior grau de escolaridade ( $50 \%$ dos entrevistados decidem sozinhos).

Conforme esperado, o fato do entrevistado trabalhar ou não fora também interferiu no padrão de resposta. Os indivíduos que trabalham fora parecem dividir mais a decisão de consumo com outros membros da familia (apenas $51 \%$ decidem sozinhos sobre o consumo, contra $69 \%$ no outro estrato).

Os indivíduos com menor renda per capita parecem estar mais envolvidos na decisão de consumo, com $73 \%$ dos entrevistados decidindo, sozinhos, sobre o consumo de frutas, seguidos da faixa intermediária ( $58 \%$ dos entrevistados) e da de maior renda ( $56 \%$ dos entrevistados).

O gasto semanal per capita, por sua vez, parece fazer com que os individuos entrevistados com maior gasto tenham um maior envolvimento com o processo decisório, sendo responsáveis pela decisão, sozinhos, em $71 \%$ dos casos. Os indivíduos da faixa de gasto intermediária decidem, sozinhos, sobre o consumo de frutas, em $61 \%$ dos casos e os da faixa de menor gasto semanal decidem, sozinhos, em $56 \%$ dos casos. 
Em relação ao fato de haver ou não individuos menores de 18 anos na unidade domiciliar, notou-se que os indivíduos entrevistados das residências somente com adultos parecem mais envolvidos no processo de decisão (decidem sozinhos sobre o consumo em $71 \%$ dos casos, contra $56 \%$ no outro estrato).

Em relação à compra propriamente dita, também foi avaliada a atuação dos diversos membros da família, conforme pode ser observado na Tabela 57. Neste sentido, pode-se notar que o entrevistado compra as frutas a serem consumidas em $62 \%$ dos casos. Em 31\% dos casos o entrevistado atua em conjunto com outros membros da família no processo de aquisição. Somente em $7 \%$ dos casos outros membros da família são responsáveis pela aquisição do produto.

Estratificando os resultados, pode-se perceber que os indivíduos do estrato até 42 anos parecem estar mais envolvidos com a aquisição de frutas (64\% dos entrevistados nesta faixa são os únicos responsáveis pela compra do produto, contra $56 \%$ no outro estrato). Outro dado interessante se relaciona com o fato de, em $18 \%$ dos casos, considerando o estrato acima de 42 anos, outros membros serem responsáveis pela compra do produto, sem interferência do entrevistado. Isso poderia estar ocorrendo devido a própria idade dos entrevistados.

Em relação à escolaridade, os entrevistados com grau de escolaridade intermediário parecem estar mais envolvidos na atividade de compra, pois $70 \%$ dos entrevistados nesta faixa disseram ser os únicos responsáveis pela aquisição de frutas. Nas faixas de menor e maior grau de escolaridade têm-se, por sua vez, $57 \%$ e $58 \%$ dos entrevistados, respectivamente, nesta situação. 


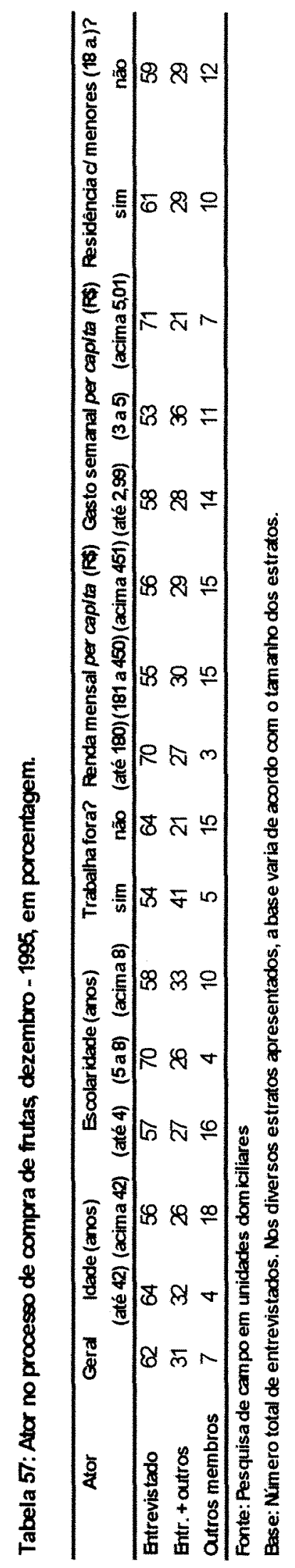


Os indivíduos entrevistados que trabalham fora da unidade domiciliar parecem, como era de se esperar, menos envolvidos na atividade de aquisição de frutas, com $54 \%$ dos entrevistados dizendo ser os únicos responsáveis por este processo, contra $64 \%$ entre os indivíduos que não trabalham.

A renda per capita também parece interferir no padrão de respostas. Os indivíduos entrevistados com menor renda parecem estar mais envolvidos na atividade de compra, sendo os únicos responsáveis por esta tarefa em $70 \%$ dos casos (contra $55 \%$ dos individuos, na faixa intermediária e 56\% na faixa de maior renda, nesta mesma situação).

Os indivíduos com maior gasto semanal per capita com frutas, por sua vez, parecem mais envolvidos na atividade de compra, com $71 \%$ dos entrevistados sendo os únicos responsáveis por esta tarefa (contra $53 \%$ dos indivíduos, na faixa intermediária e $58 \%$ na faixa de menor gasto semanal, nesta mesma situação).

Finalmente, em relação ao fato de haver ou não indivíduos menores de 18 anos na unidade domiciliar, não pode ser observada uma alteração significativa no padrão de resposta.

\subsection{Pós-compra}

Conforme mencionado anteriormente, a análise do comportamento do consumidor não deve se encerrar após a compra de determinado produto. Assim sendo, o armazenamento e o preparo do produto (pré-consumo), as situações de consumo (consumo) e as sensações pós-consumo (pós-consumo) são muito importantes na análise do comportamento do consumidor. No caso específico de frutas, devido a alta percecibilidade do produto, surge também um item importante, que é o descarte. 
Conforme pode ser observado na Tabela 58, foram levantados dados a respeito do armazenamento das frutas nas unidades domiciliares. A maioria dos entrevistados disse armazenar as frutas dentro e fora da geladeira, dependendo do tipo de fruta e da quantidade adquirida ( $46 \%$ dos entrevistados). A geladeira foi apontada como único local utilizado para armazenar o produto por $45 \%$ dos entrevistados. Somente $9 \%$ dos entrevistados afirmaram armazenar as frutas somente fora da geladeira. Os dados estratificados também podem ser observados na Tabela 58, embora seja dificil extrair informações conclusivas a partir dos mesmos.

Em relação ao preparo ${ }^{32}$ das frutas nas residências, foram levantados dados a respeito da frequiência de preparo do produto, conforme pode ser observado na Tabela 59. A maioria dos indivíduos entrevistados diz preparar as frutas para o consumo (35\% afirmaram que preparam o produto sempre e $27 \%$ afirmaram preparar as frutas para 0 consumo freqüentemente). Uma parte dos entrevistados disse preparar o produto com uma frequêencia mediana ( $12 \%$ ). Finalmente, para $25 \%$ dos entrevistados foi raro ocorrer preparo do produto e para $1 \%$ isso nunca ocorreu.

Estratificando os resultados, pode-se observar que, os indivíduos da faixa até 42 anos parecem preparar mais o produto antes do consumo, pois $44 \%$ dos entrevistados desta faixa afirmaram preparar o produto sempre (contra $26 \%$ no outro estrato), $26 \%$ afirmaram preparar o produto frequientemente ( $28 \%$ no outro estrato), $10 \%$ preparam o produto com uma frequêencia mediana ( $14 \%$ no outro estrato) e $20 \%$ raramente preparam o produto (contra $30 \%$ no outro estrato). No estrato de maior faixa etária ainda existem $2 \%$ dos indivíduos que afirmaram nunca preparar o produto.

\footnotetext{
${ }^{32}$ Preparo, neste caso, significa utilizar as frutas para fazer um suco, uma vitamina ou qualquer tipo de prato que utilize o produto como ingrediente.
} 

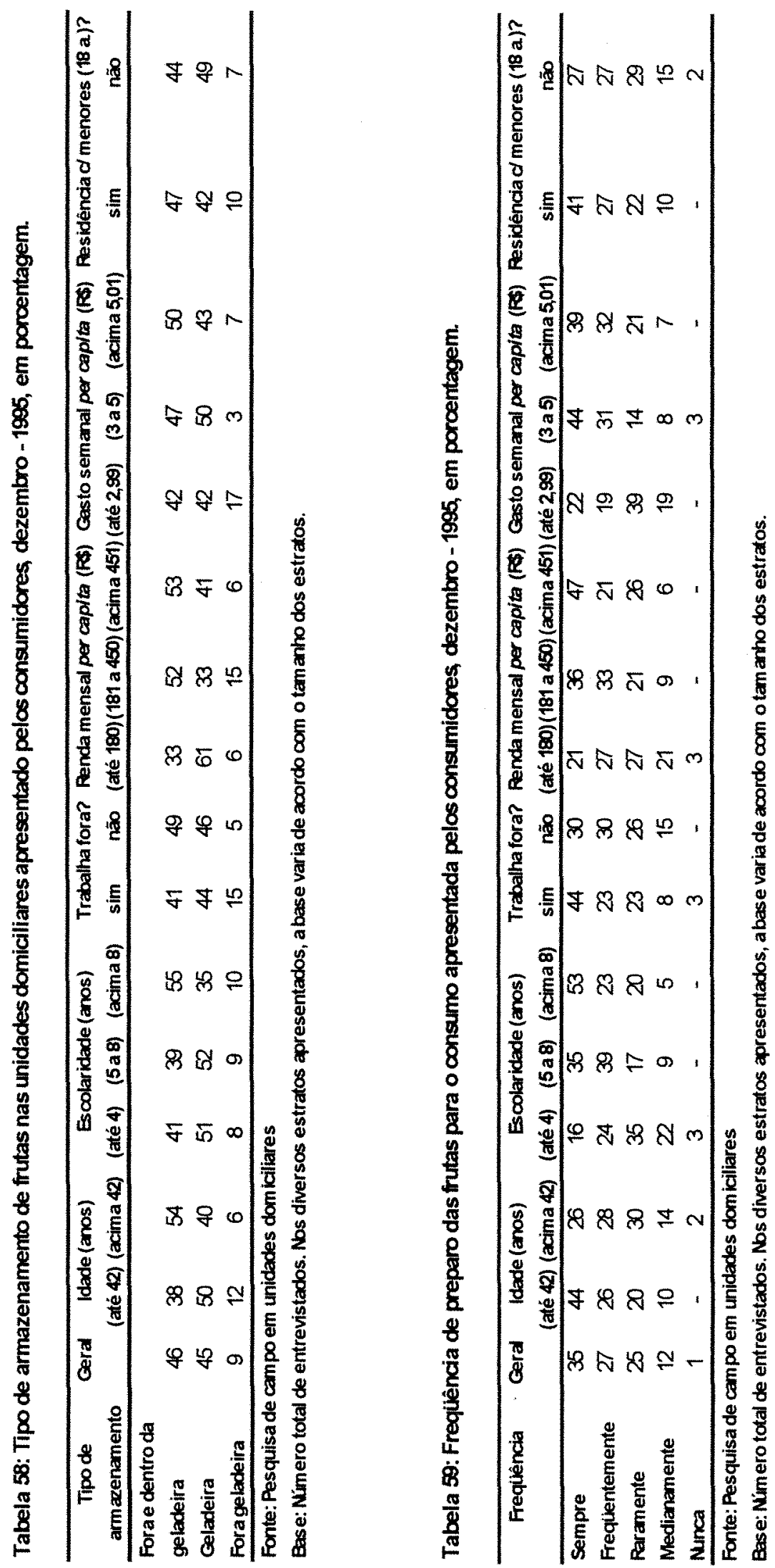
A escolaridade também parece causar variações nos padrões de resposta. Os individuos com maior grau de escolaridade parecem preparar mais as frutas antes do consumo, com $53 \%$ dos indivíduos da faixa com maior grau de escolaridade dizendo preparar sempre o produto, contra $35 \%$ na faixa intermediária e $16 \%$ na faixa com menor grau de escolaridade.

De maneira diferente do esperado, os individuos que trabalham fora parecem preparar mais as frutas para o consumo, com $44 \%$ dos entrevistados dizendo preparar sempre o produto, contra $30 \%$ no outro estrato.

A renda e o gasto semanal com frutas (per capita), conforme pode ser observado, não permitem resultados muito conclusivos a respeito da influência da estratificação sobre os resultados apresentados.

Em relação ao fato de haver ou não menores de 18 anos na unidade domiciliar, por sua vez, pode-se notar uma tendência de aumento do preparo do produto nas unidades domiciliares com menores, pois $41 \%$ dos entrevistados deste estrato afirmaram preparar sempre o produto (contra $27 \%$ no outro estrato)

Para avaliar a influência da situação de consumo ${ }^{33}$ sobre os tipos de frutas consumidos, questionou-se, aos entrevistados, se eles achavam que a situação de consumo tinha alguma influência sobre o tipo de frutas a ser consumido. Conforme pode ser observado na Tabela $60,85 \%$ dos entrevistados afirmaram que a situação de consumo não tem influência sobre o tipo de fruta consumido, $14 \%$ afirmaram que a influência ocorre e $1 \%$ disseram que depende da situação.

\footnotetext{
${ }^{33}$ A situação de consumo, neste caso, corresponde à conjuntura na qual ocorre o consumo do produto. Como exemplo, pode-se citar as refeições diárias (café da manhã, almoço, jantar).
} 


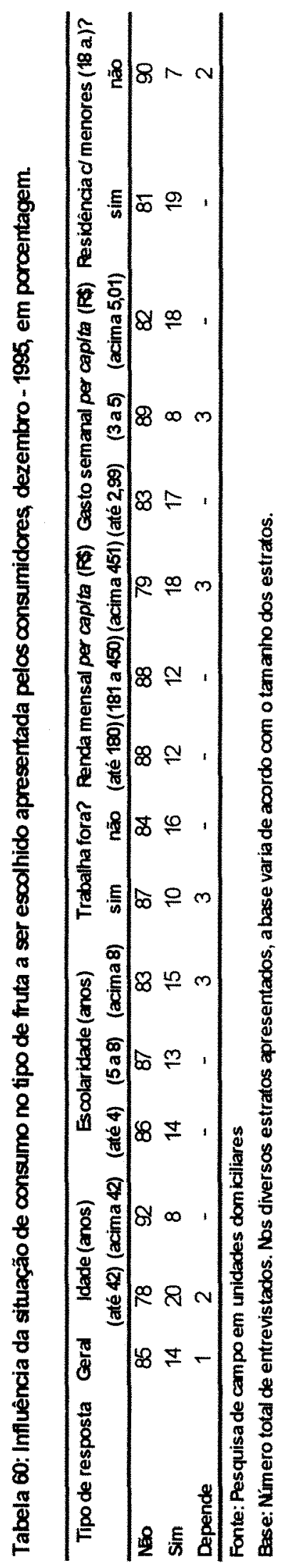


Analisando os dados estratificados, pode-se perceber que as maiores variações ocorrem em relação a: idade, renda per capita e fato de haver ou não indivíduos menores na unidade domiciliar.

Os individuos mais idosos parecem sofrer menos influência da situação de consumo, uma vez que $92 \%$ dos entrevistados deste estrato afirmaram não sofrer influência da situação de consumo, contra $78 \%$ dos entrevistados no outro estrato.

Em relação à renda per capita, os indivíduos com maior renda parecem ser mais influenciados pela situação de consumo, com $18 \%$ dos entrevistados do estrato de maior renda dizendo que a influência ocorre, contra $12 \%$ nos outros dois estratos.

Por fim, os indivíduos de unidades domiciliares somente com adultos parecem sofrer menor influência da situação de consumo, com $90 \%$ dos entrevistados afirmando que a influência não ocorre, contra $81 \%$ entre os entrevistados de residências com indivíduos menores.

Ainda avaliando a situação de consumo, foram apresentadas aos entrevistados diversas situações, perguntando-se aos mesmos se eram consumidas frutas em cada uma delas e, caso fossem, quais eram os tipos mais consumidos. As situações de consumo apresentadas foram: café da manhã, lanche durante a manhã, sobremesa do almoço, lanche durante a tarde, sobremesa do jantar e lanche antes de dormir.

Em relação ao café da manhã, $63 \%$ dos entrevistados afirmaram consumir frutas nesta situação (Tabela 61). As variações mais interessantes, ao realizar-se a estratificação, foram referentes a grau de escolaridade, renda per capita, gasto semanal per capita e fato de haver ou não menores de 18 anos na residência. 


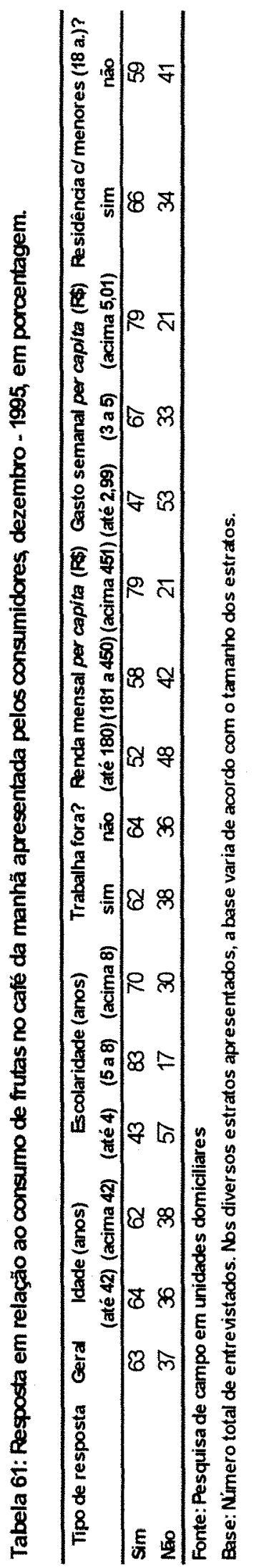


Conforme pode ser observado na Tabela 61, o consumo de frutas no café da manhã parece aumentar de acordo com o grau de escolaridade, com $83 \%$ dos entrevistados da faixa de 5 a 8 anos de estudo dizendo consumir frutas nesta situação, $70 \%$ dos entrevistados na faixa de maior grau de escolaridade e apenas $43 \%$ na faixa de menor grau de escolaridade.

O consumo de frutas no café da manhã também parece aumentar com a renda, com $79 \%$ dos entrevistados da faixa de maior renda afirmando consumir frutas nesta situação, contra $58 \%$ na faixa intermediária e $52 \%$ na faixa de menor renda.

O padrão de resposta também se altera ao realizar-se a estratificação por faixas de gasto semanal. Os entrevistados do estrato de maior gasto semanal parecem consumir mais frutas no café da manhã ( $79 \%$ dos entrevistados), seguidos do estrato intermediário ( $67 \%$ dos entrevistados) e do de menor gasto ( $47 \%$ dos entrevistados).

Os indivíduos das unidades domiciliares com menores de 18 anos também parecem consumir mais frutas no café da manhã, com $66 \%$ dos entrevistados afirmando consumir frutas nesta situação, contra $59 \%$ no outro estrato.

As frutas mais consumidas no café da manhã também foram levantadas (Tabela 62). Conforme pode ser observado, as frutas mais consumidas foram: mamão, laranja e maçã, em ordem decrescente de importância. Ao realizar-se a estratificação, não ocorrem diferenças muito grandes na ordem de preferência.

Quando a situação apresentada foi um lanche durante a manhã, $72 \%$ dos entrevistados afirmaram consumir frutas nesta situação (Tabela 63). Percebe-se, ao estratificar-se os resultados, que ocorrem algumas variações no padrão de respostas. 

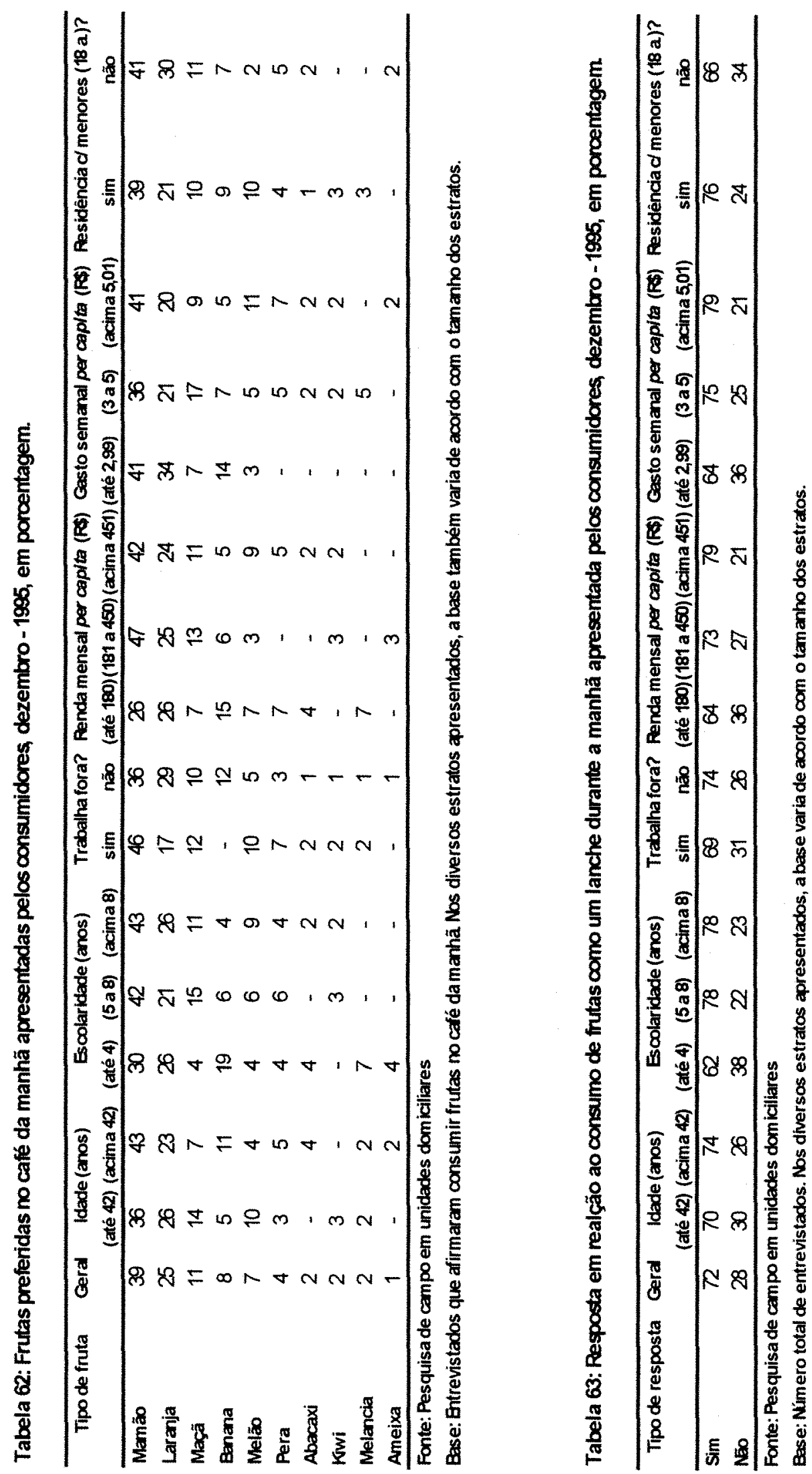
Os indivíduos do estrato mais idoso parecem consumir mais frutas nesta situação, com $74 \%$ dos entrevistados desta faixa afirmando consumir frutas (contra $70 \%$ no outro estrato etário).

$\mathrm{O}$ consumo de frutas em um lanche durante a manhã também parece aumentar com o grau de escolaridade. Setenta e oito porcento (78\%) dos entrevistados dos estratos com maior grau de escolaridade e intermediário afirmaram consumir frutas nesta situação, contra $62 \%$ no estrato com menor grau de escolaridade.

Os indivíduos que não trabalham fora também parecem consumir mais frutas em um lanche durante a manhã ( $74 \%$ dos entrevistados, contra $69 \%$ entre os individuos que trabalham fora).

A renda per capita também parece alterar o padrão de resposta. Conforme esperado, os indivíduos com maior renda consomem mais frutas em um lanche durante a manhã, com $79 \%$ dos entrevistados da faixa de maior renda afirmando consumir o produto nesta situação, contra $73 \%$ na faixa de renda intermediária e $64 \%$ na faixa de menor renda.

Assim como a renda, o gasto semanal per capita com frutas também parece alterar o padrão de resposta. Os entrevistados da faixa de maior gasto parecem consumir mais frutas em um lanche durante a manhã, com $79 \%$ dos entrevistados afirmando consumir o produto nesta situação, contra $75 \%$ na faixa intermediária e $64 \%$ na faixa de menor gasto semanal.

Por fim, as unidades domiciliares com indivíduos menores de 18 anos parecem consumir mais frutas em um lanche durante a manhã, com $76 \%$ dos entrevistados afirmando consumir frutas nesta situação, contra $66 \%$ no outro estrato. 
As frutas mais consumidas em um lanche durante a manhã também foram levantadas (Tabela 64). Conforme pode ser observado, as frutas mais consumidas foram: maçã, laranja e banana, em ordem decrescente de importância. Ao realizar-se a estratificação ocorrem apenas algumas diferenças na ordem de preferência, conforme pode ser também observado na Tabela 64.

Em relação ao consumo de frutas como sobremesa do almoço, nota-se, conforme pode ser observado na Tabela 65 , que $89 \%$ dos entrevistados afirmaram consumir frutas nesta situação. Ao estratificar-se os resultados, pode-se perceber algumas variações no padrão de resposta, analisadas a seguir.

Os individuos do estrato com idade mais elevada (acima 42 anos) parecem consumir mais frutas como sobremesa do almoço, com $92 \%$ dos entrevistados afirmando consumir o produto nesta situação, contra $86 \%$ no outro estrato.

Em relação ao grau de escolaridade, o estrato com menor grau de escolaridade parece consumir mais frutas como sobremesa do almoço, com 95\% dos entrevistados afirmando consumir o produto nesta situação. Em segundo lugar, encontra-se o estrato com maior grau de escolaridade ( $88 \%$ dos entrevistados). Por fim, tem-se o estrato com escolaridade intermediária, com $83 \%$ dos entrevistados afirmando consumir o produto nesta situação.

Conforme poderia ser esperado, os individuos entrevistados que não trabalham fora da unidade domiciliar parecem consumir mais frutas como sobremesa do almoço, com $93 \%$ dos entrevistados afirmando consumir o produto nesta situação, contra $82 \%$ no outro estrato 

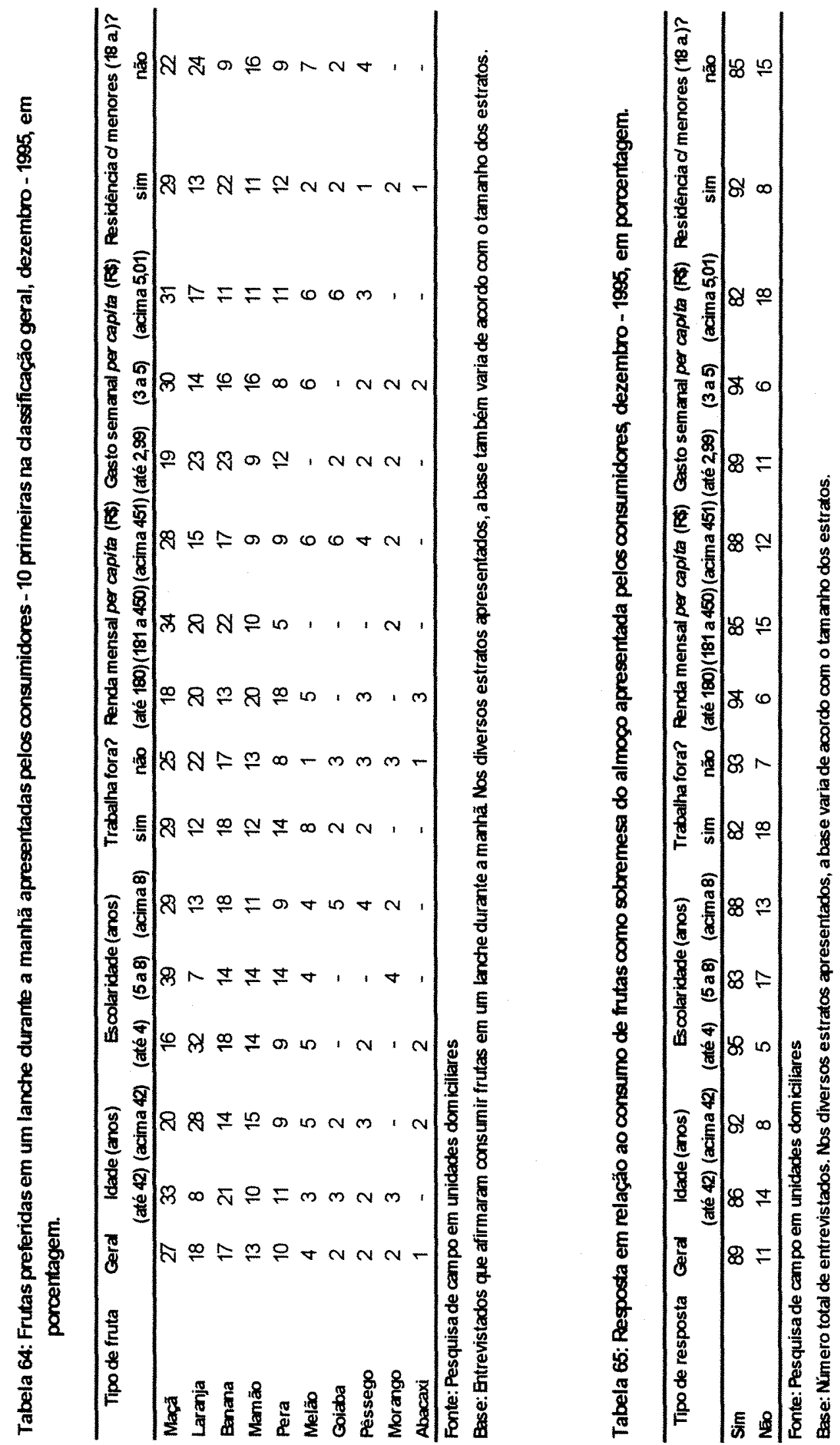
Em relação a renda per capita também pode-se notar uma alteração no padrão de respostas causada pela estratificação. Os indivíduos com menor renda parecem consumir mais frutas como sobremesa do almoço, com $94 \%$ dos entrevistados afirmando consumir frutas nesta situação. Em segundo lugar, encontram-se os indivíduos com maior renda ( $88 \%$ dos entrevistados). Por fim, têm-se os indivíduos da faixa de renda intermediária, com $85 \%$ dos entrevistados respondendo afirmativamente a esta questão.

O gasto semanal per capita com frutas também interfere no padrão de resposta. Os indivíduos do estrato intermediário parecem consumir mais frutas como sobremesa do almoço, com $94 \%$ dos entrevistados afirmando consumir o produto nesta situação, contra $89 \%$ na faixa de menor gasto e $82 \%$ na faixa de maior gasto.

Por fim, em relação ao fato de haver ou não indivíduos menores de 18 anos nas unidades domiciliares, nota-se que os entrevistados das residências com menores parecem consumir mais frutas como sobremesa do almoço, com $92 \%$ dos entrevistados respondendo afirmativamente a esta questão, contra $85 \%$ no outro estrato.

As frutas mais consumidas como sobremesa do almoço foram levantadas, conforme pode ser observado na Tabela 66. As frutas mais consumidas nesta situação foram: laranja, banana e maçã, em ordem decrescente de importância. Ao realizar-se a estratificação ocorrem apenas algumas diferenças na ordem de preferência, conforme pode ser também observado na Tabela 66 .

O consumo de frutas em um lanche durante a tarde também foi analisado. Neste caso, $77 \%$ dos entrevistados afirmaram consumir o produto, conforme pode ser observado na Tabela 67. 

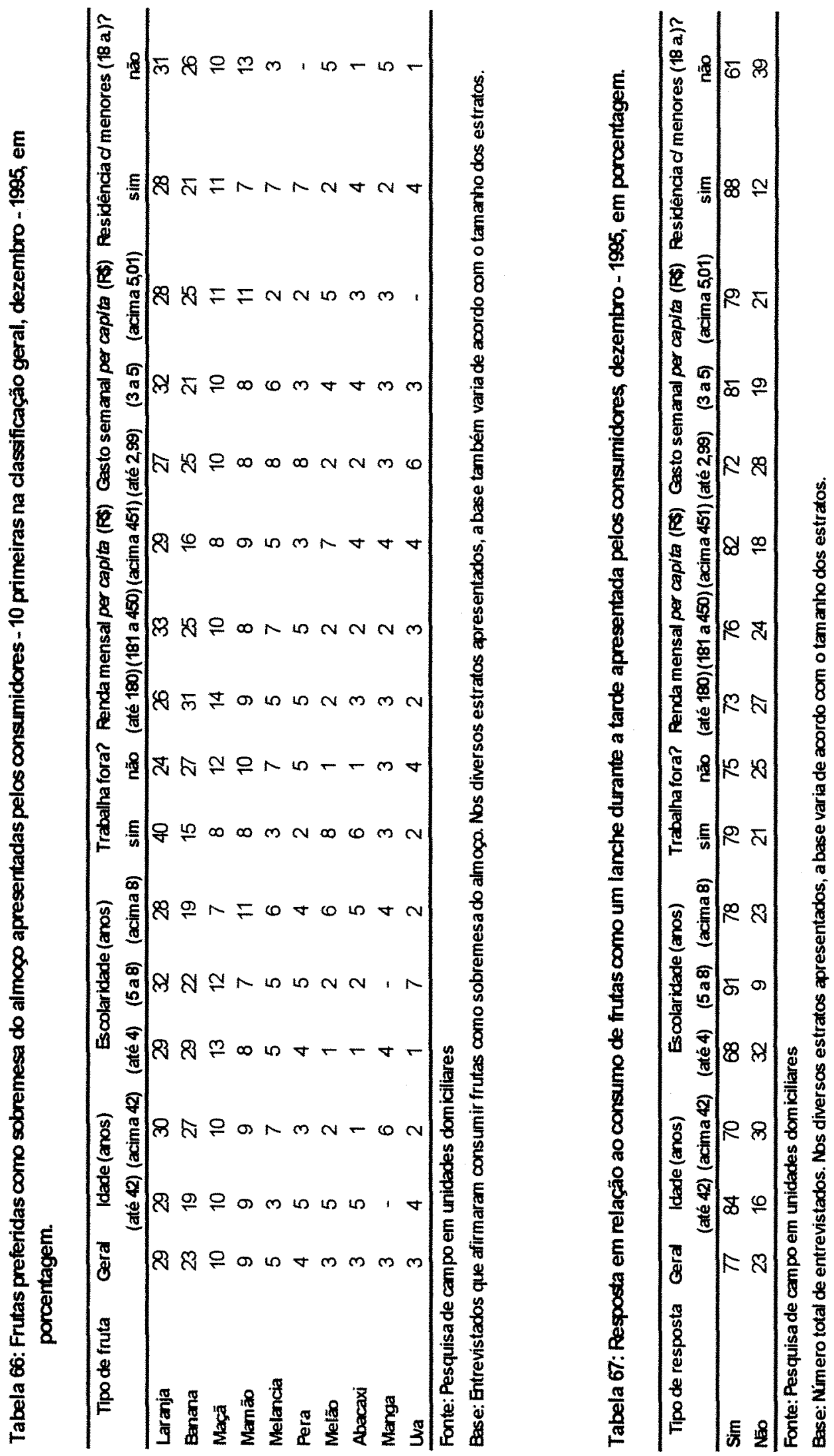
Ao realizar-se a estratificação ocorrem algumas alterações no padrão de resposta. As principais alterações são discutidas a seguir.

Os indivíduos do estrato mais novo (até 42 anos) parecem consumir mais frutas em um lanche durante a tarde, com $84 \%$ dos entrevistados afirmando consumir o produto nesta situação, contra $70 \%$ entre os indivíduos do estrato mais idoso.

Em relação ao grau de escolaridade, os indivíduos com grau de escolaridade intermediário ( 5 a 8 anos de estudo) parecem consumir mais frutas em um lanche durante a tarde, com $91 \%$ dos entrevistados afirmando consumir frutas nesta situação, contra $78 \%$ no estrato com maior grau de escolaridade e apenas $68 \%$ no estrato com menor grau.

A renda per capita também parece interferir no padrão de resposta. Os individuos com maior renda parecem consumir mais frutas como um lanche durante a tarde, com $82 \%$ dos entrevistados afirmando consumir o produto nesta situação, contra $76 \%$ na faixa intermediária e $73 \%$ na faixa de menor renda.

Os indivíduos com gasto semanal per capita com frutas na faixa intermediária parecem, por sua vez, consumir mais frutas como um lanche durante a tarde, com $81 \%$ dos entrevistados afirmando consumir o produto nesta situação. Em seguida, têm-se os indivíduos da faixa de maior gasto, com $79 \%$ dos entrevistados nesta situação. A faixa de menor gasto aparece na terceira posição, com $72 \%$ dos entrevistados afirmando consumir o produto.

Finalmente, em relação ao fato de haver ou não indivíduos menores de 18 anos na unidade domiciliar, nota-se que os entrevistados pertencentes a residências com indivíduos menores parecem consumir mais frutas em um lanche durante a tarde, com 
$88 \%$ dos entrevistados afirmando consumir o produto nesta situação, contra $61 \%$ entre os entrevistados de unidades domiciliares habitadas apenas por indivíduos adultos.

As frutas mais consumidas em um lanche durante a tarde também foram levantadas, conforme pode ser observado na Tabela 68. As frutas mais consumidas nesta situação foram, em primeiro lugar, a maçã, com a banana e a laranja empatadas na segunda posição. Ao realizar-se a estratificação ocorrem algumas diferenças na ordem de preferência, conforme pode ser também observado na Tabela 68 , no entanto, estas três frutas são consideradas as preferidas em quase todos os estratos.

Em relação ao consumo de frutas como sobremesa do jantar, nota-se, conforme pode ser observado na Tabela 69 , que $67 \%$ dos entrevistados afirmaram consumir frutas nesta situação.

Ao estratificar-se os resultados, pode-se perceber algumas variações no padrão de resposta. Os indivíduos mais novos parecem consumir mais frutas como sobremesa do jantar, com $72 \%$ dos entrevistados afirmando consumir o produto nesta situação, contra $62 \%$ entre os indivíduos da faixa acima de 42 anos.

O grau de escolaridade também parece afetar o padrão de resposta. Os indivíduos com grau intermediário de escolaridade parecem consumir mais frutas como sobremesa do jantar, com $74 \%$ dos entrevistados deste estrato afirmando consumir o produto, contra $65 \%$ nos outros dois estratos. 

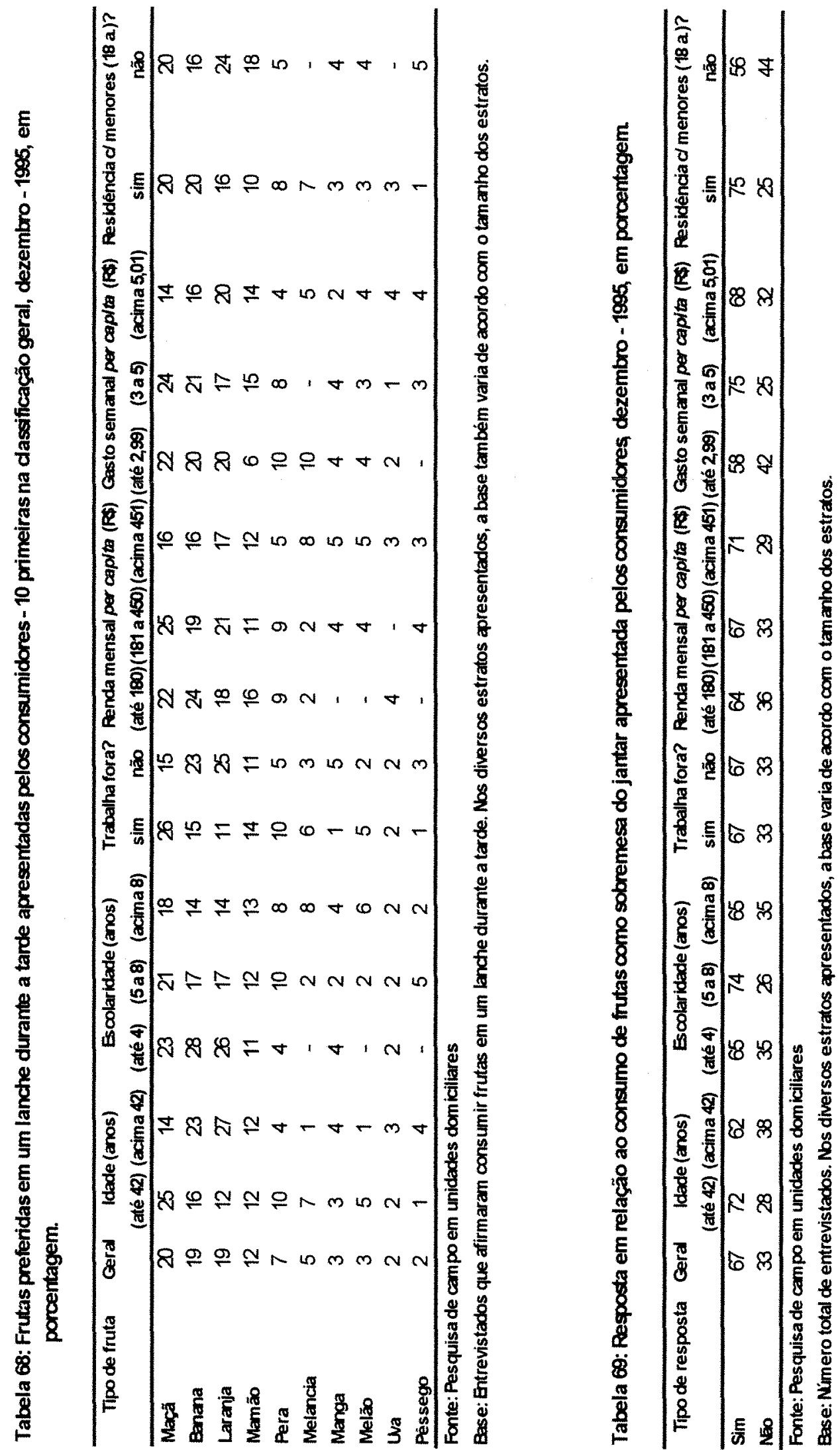
Em relação ao gasto semanal per capita com frutas, os indivíduos da faixa de gasto intermediária parecem consumir mais frutas como sobremesa do jantar, com $75 \%$ dos entrevistados afirmando consumir o produto. Em segundo lugar, têm-se os indivíduos com maior gasto, com $68 \%$ dos entrevistados afirmando consumir o produto nesta situação. Finalmente, têm-se os indivíduos com menor gasto semanal, com $58 \%$ de respostas afirmativas neste sentido.

Os indivíduos entrevistados de unidades domiciliares com indivíduos menores também parecem consumir mais frutas após o jantar, com $75 \%$ dos entrevistados afirmando consumir o produto nesta situação, contra $56 \%$ no outro estrato.

As frutas mais consumidas como sobremesa do jantar foram levantadas, conforme pode ser observado na Tabela 70. As frutas mais consumidas nesta situação foram: laranja, banana e maçã, em ordem decrescente de importância. Ao realizar-se a estratificação ocorrem algumas diferenças na ordem de preferência, conforme pode ser também observado na Tabela 70 .

A última situação de consumo considerada foi um lanche antes de dormir. Neste caso, $51 \%$ dos entrevistados afirmaram consumir frutas nesta situação, conforme pode ser observado na Tabela 71 .

Em relação à estratificação, pode-se perceber algumas alterações no padrão de resposta. Os indivíduos mais velhos (faixa acima de 42 anos) parecem consumir mais frutas em um lanche antes de dormir, com $60 \%$ dos entrevistados afirmando consumir o produto nesta situação, contra $42 \%$ no outro estrato. 

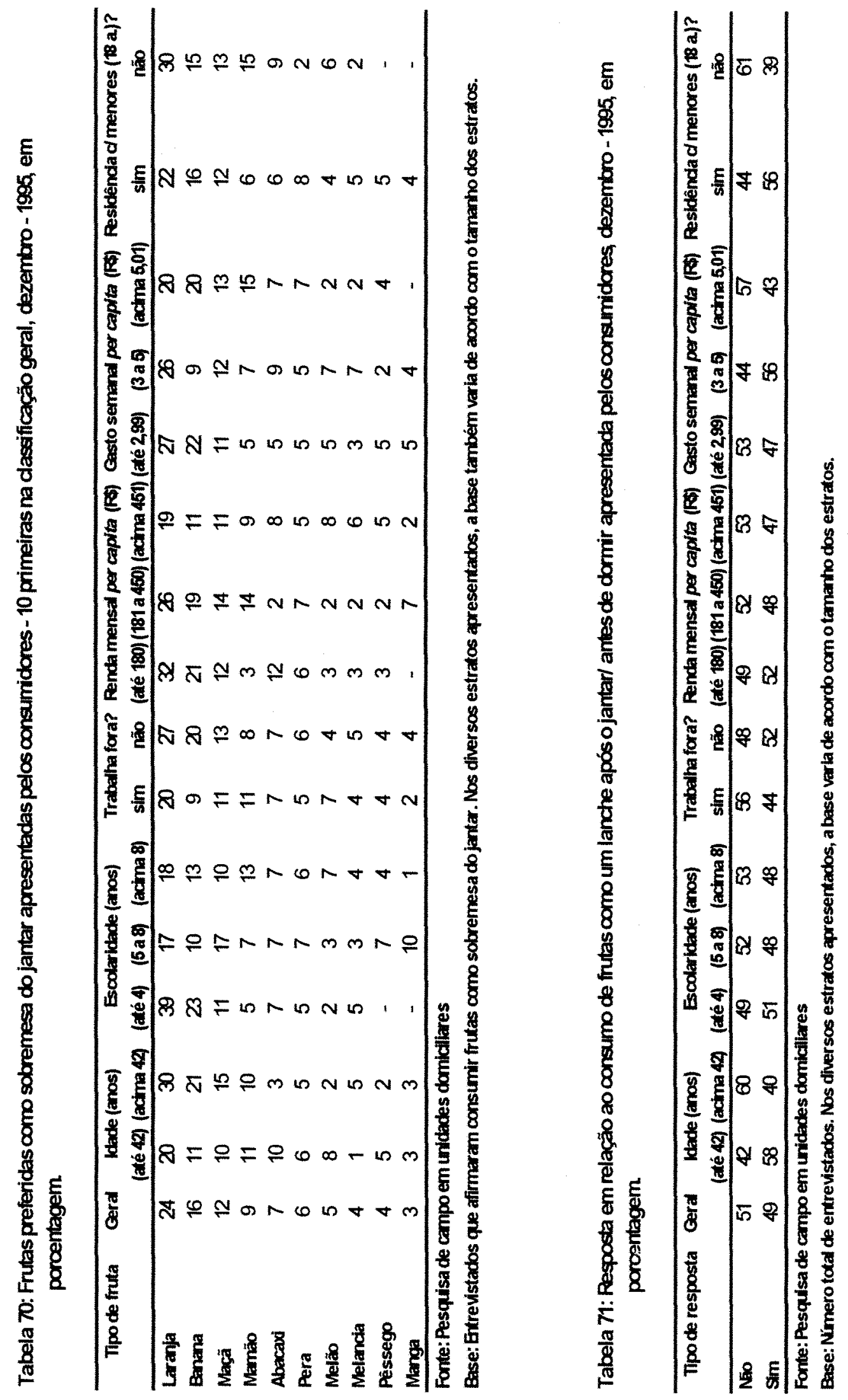
O fato do indivíduo entrevistado trabalhar ou não fora também parece interferir no padrão de resposta. Os indivíduos que trabalham fora parecem consumir mais frutas em um lanche antes de dormir, com 56\% dos entrevistados afirmando consumir o produto nesta situação, contra $48 \%$ no outro estrato.

Finalmente, o fato de haver ou não indivíduos menores de 18 anos na unidade domiciliar também parece interferir no padrão de resposta. Os entrevistados de unidades domiciliares somente com indivíduos adultos parecem consumir mais frutas em um lanche antes de dormir, com $61 \%$ dos indivíduos afirmando consumir o produto nesta situação, contra $44 \%$ no outro estrato.

As frutas mais consumidas em um lanche antes de dormir também foram levantadas, conforme pode ser observado na Tabela 72. As frutas mais consumidas nesta situação foram: maçã, laranja e mamão, em ordem decrescente de importância. Ao realizar-se a estratificação ocorrem algumas diferenças na ordem de preferência, conforme pode ser também observado na Tabela 72 .

Com o objetivo de avaliar as sensações pós-consumo, verificou-se o grau de satisfação dos consumidores em relação às frutas adquiridas. Conforme pode ser observado na Tabela 73, 16\% dos entrevistados afirmaram estar totalmente satisfeitos com os produtos adquiridos, $54 \%$ se disseram bastante satisfeitos, $25 \%$ afirmaram estar moderadamente satisfeitos e $5 \%$ afirmaram estar pouco satisfeitos com os produtos adquiridos.

Conforme pode ser também observado na Tabela 73, a estratificação parece causar algumas mudanças no padrão de resposta. Os indivíduos da faixa acima de 42 anos parecem mais satisfeitos com as frutas adquiridas, com $74 \%$ dos entrevistados afirmando estar bastante ou totalmente satisfeitos com os produtos adquiridos, contra $66 \%$ no outro estrato. 


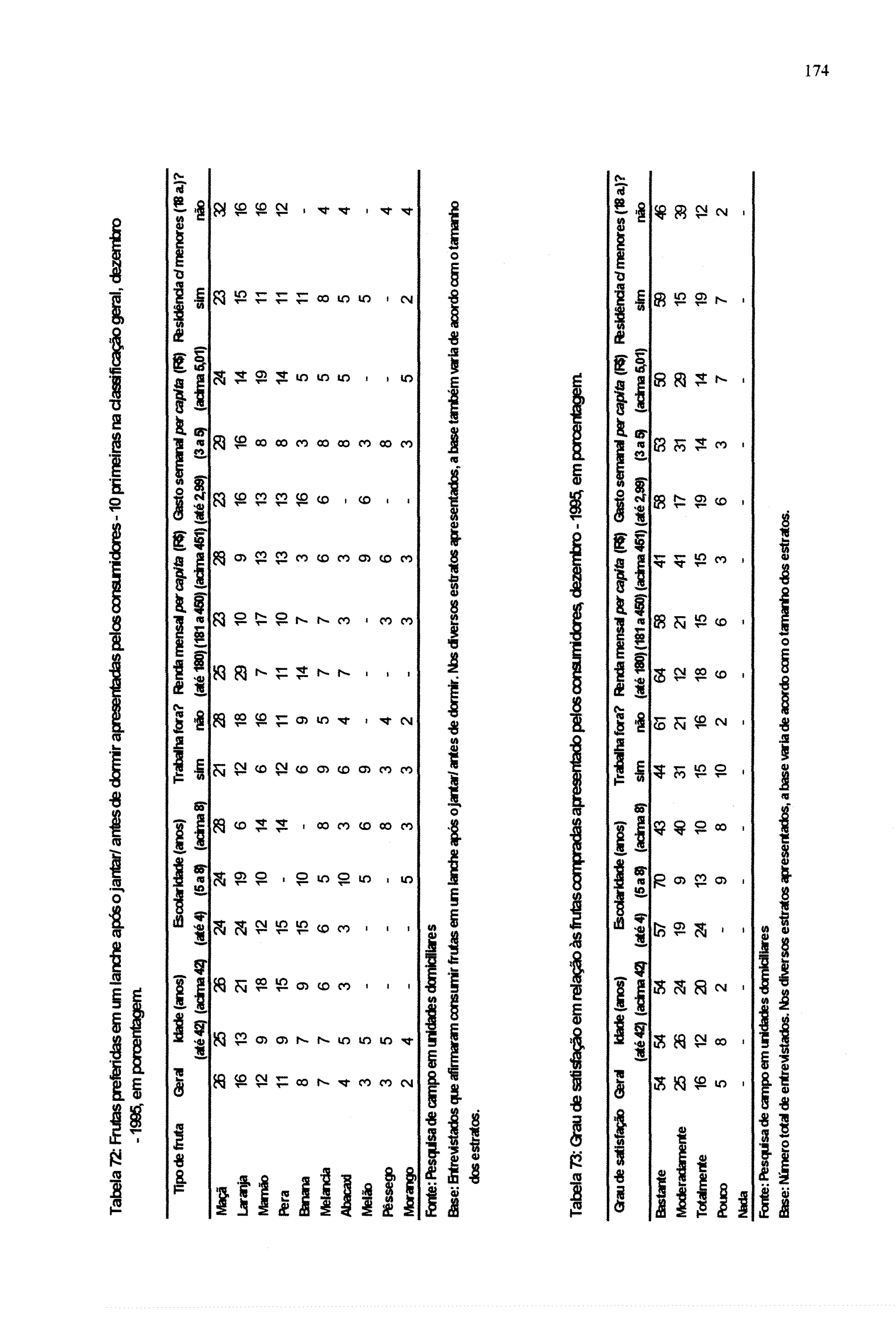


Em relação ao número de anos de estudo, os indivíduos com menor grau de escolaridade parecem estar mais satisfeitos com os produtos que consomem, com $81 \%$ dos entrevistados da faixa de menor escolaridade e $83 \%$ da faixa intermediária afirmando estar totalmente ou bastante satisfeitos com os produtos adquiridos, contra $53 \%$ no estrato acima de 8 anos de estudo.

Os individuos que não trabalham fora também parecem estar mais satisfeitos com os produtos adquiridos, com $77 \%$ dos entrevistados afirmando estar totalmente ou bastante satisfeitos, contra $59 \%$ no outro estrato.

A renda per capita também parece exercer influência sobre os resultados. Os indivíduos de menor renda parecem estar mais satisfeitos com as frutas que consomem, com $82 \%$ dos indivíduos da faixa de menor renda afirmando estar totalmente ou bastante satisfeitos com o produto. Na faixa intermediária, este número cai para $73 \%$ e na de renda mais alta para $56 \%$.

Em relação ao gasto semanal per capita com frutas também pode-se notar que os indivíduos com menor gasto parecem estar mais satisfeitos com os produtos adquiridos, com $77 \%$ dos indivíduos da faixa de menor gasto afirmando estar totalmente ou bastante satisfeitos com o produto. Na faixa intermediária, este número cai par $67 \% \mathrm{e}$ na de renda mais alta para $64 \%$.

Finalmente, em relação ao fato de haver ou não indivíduos menores de 18 anos na unidade domiciliar, parece haver um maior grau de satisfação com as frutas adquiridas entre os entrevistados de residências com indivíduos menores, com $78 \%$ de citações entre totalmente e bastante satisfeitos, contra $58 \%$ no outro estrato

Após a verificação do grau de satisfação dos consumidores em relação às frutas adquiridas, também foram analisados os motivos desta posição. 
Os entrevistados que disseram estar pouco satisfeitos com o produto adquirido apresentaram como motivos: qualidade ruim ( $60 \%$ dos indivíduos), presença de produtos químicos ( $20 \%$ ) e poucas opções de escolha ( $20 \%$ dos entrevistados), conforme pode ser observado na Tabela 74. Ao realizar-se a estratificação dos resultados, ocorrem algumas mudanças no padrão de resposta, conforme pode ser também observado na Tabela 74 . Estas mudanças, no entanto, podem não ser muito confiáveis, uma vez que apenas $6 \%$ dos entrevistados afirmaram estar pouco satisfeitos com os produtos que consomem.

Quando os consumidores se disseram moderadamente satisfeitos com os produtos consumidos, os motivos foram: qualidade ruim (62\% dos entrevistados), preço alto $(17 \%)$, decepção com o sabor do produto $(7 \%)$, despadronização dos produtos $(3 \%)$, qualidade boa ( $3 \%$ dos entrevistados, valendo ressaltar que esta alternativa sempre foi acompanhada de uma alternativa negativa), presença de produtos químicos $(3 \%)$ e poucas opções de escolha (3\%), conforme pode ser observado na Tabela 75 . Analisando os resultados estratificados, notam-se várias diferenças no padrão de resposta, mas fica complicado tirar informações mais conclusivas a respeito do assunto.

Os consumidores que se disseram bastante satisfeitos com as frutas que consomem apresentaram os seguintes motivos: qualidade boa ( $87 \%$ dos entrevistados), produtos frescos $(7 \%$ dos entrevistados), preços bons $(3 \%)$, presença de produtos químicos ( $2 \%$ dos entrevistados, sempre acompanhada de uma resposta positiva) e decepção com sabor ( $2 \%$ dos entrevistados, também sempre acompanhada de uma resposta positiva), conforme pode ser observado na Tabela 76 . A estratificação dos resultados também não permite que sejam tiradas informações conclusivas a respeito das alterações apresentadas. 

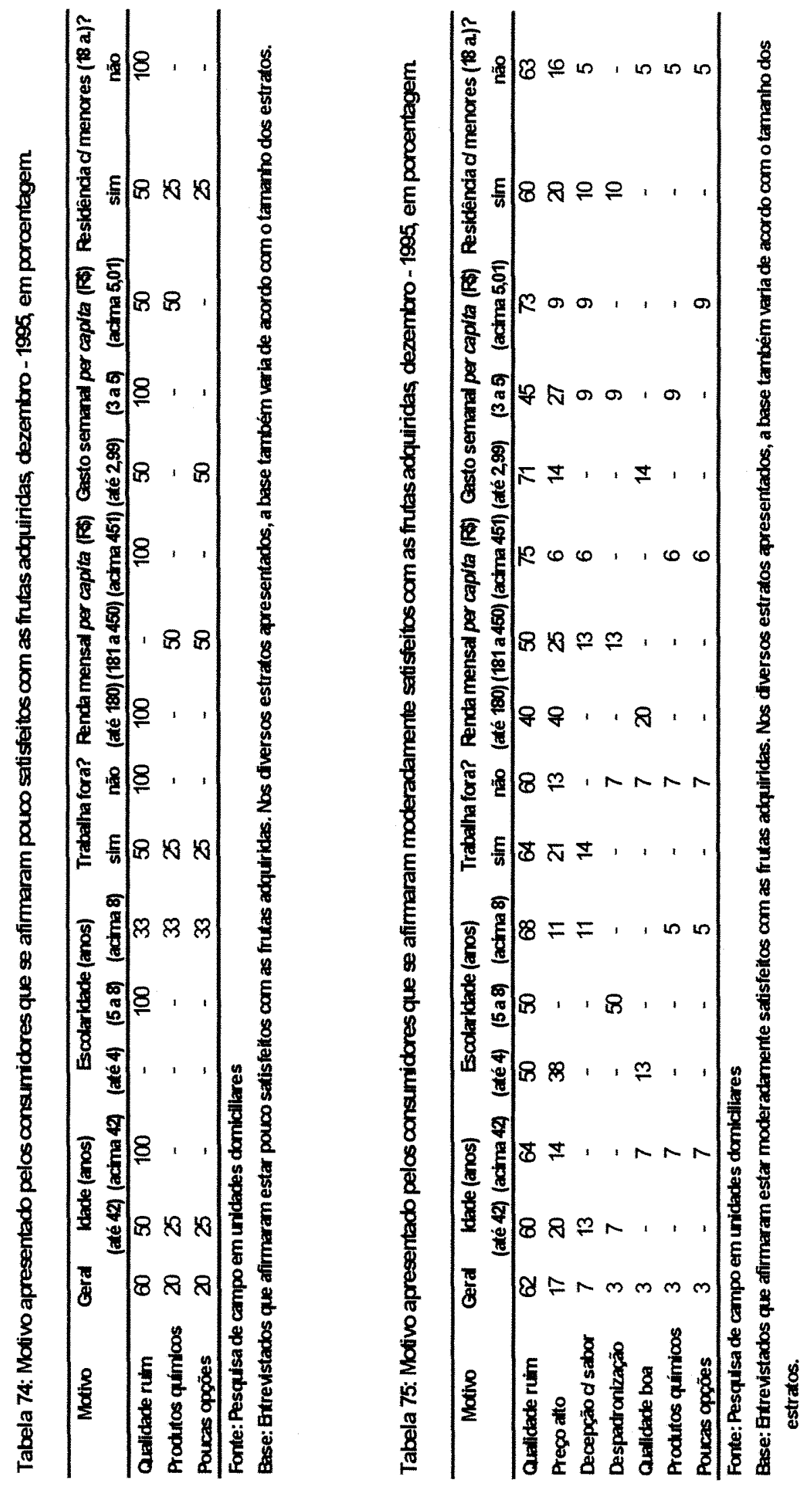
178

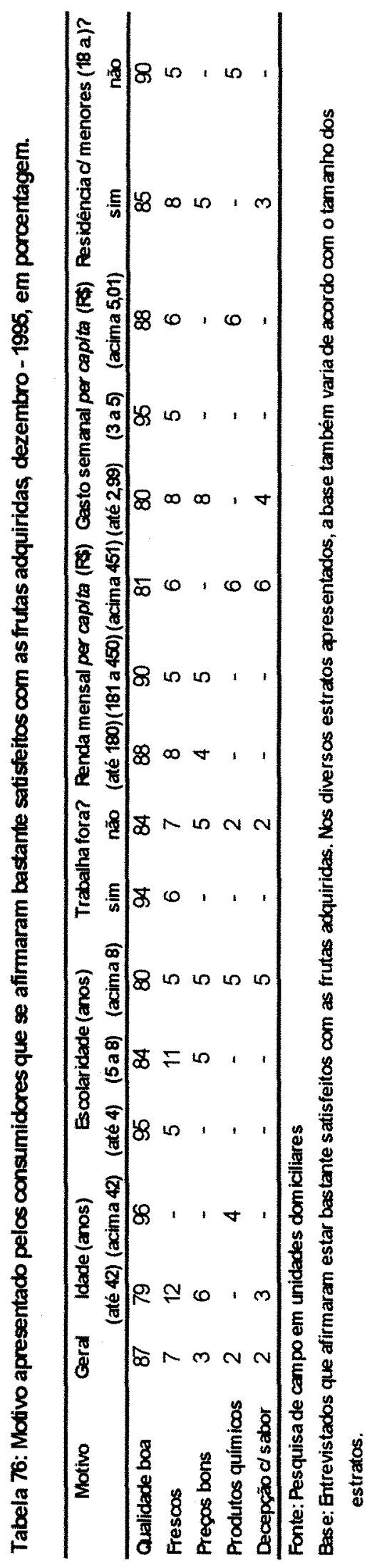


Finalmente, quando os consumidores disseram estar totalmente satisfeitos com os produtos que consomem, os motivos apresentados foram: qualidade boa ( $89 \%$ dos entrevistados) e produtos frescos (11\%), conforme pode ser observado na Tabela 77 . A estratificação dos resultados também não permite que sejam tiradas conclusões sobre o assunto, neste caso.

Para finalizar a análise da fase de pós-compra, também foi avaliado o item descarte. Neste sentido, foram levantadas informações a respeito do grau de desperdício de frutas e do destino dos resíduos após o consumo dos produtos.

Quando indagados sobre o grau de desperdício de frutas na unidade domiciliar, $45 \%$ dos entrevistados afirmaram que não ocorre qualquer desperdício, $42 \%$ afirmaram que ocorre um pouco de desperdício e $13 \%$ disseram haver um desperdício moderado na unidade domiciliar, conforme pode ser observado na Tabela 78 .

Ao realizar-se a estratificação, ocorrem algumas alterações no padrão de resposta, conforme pode ser observado na Tabela 78. A alteração mais contundente refere-se a renda per capita dos entrevistados. Conforme poderia ser esperado, o grau de desperdício parece aumentar conforme a renda aumenta.

Após a verificação do grau de desperdício de frutas nas unidades domiciliares, foram analisados os motivos apresentados para este desperdício.

Os entrevistados que disseram não haver qualquer desperdício do produto na unidade domiciliar apresentaram os seguintes motivos para tal: compram somente o necessário ( $40 \%$ dos entrevistados), consumo é alto ( $40 \%$ dos entrevistados) e aproveita o produto para fazer doces quando este não é consumido logo ( $20 \%$ dos entrevistados), conforme pode ser observado na Tabela 79 . 

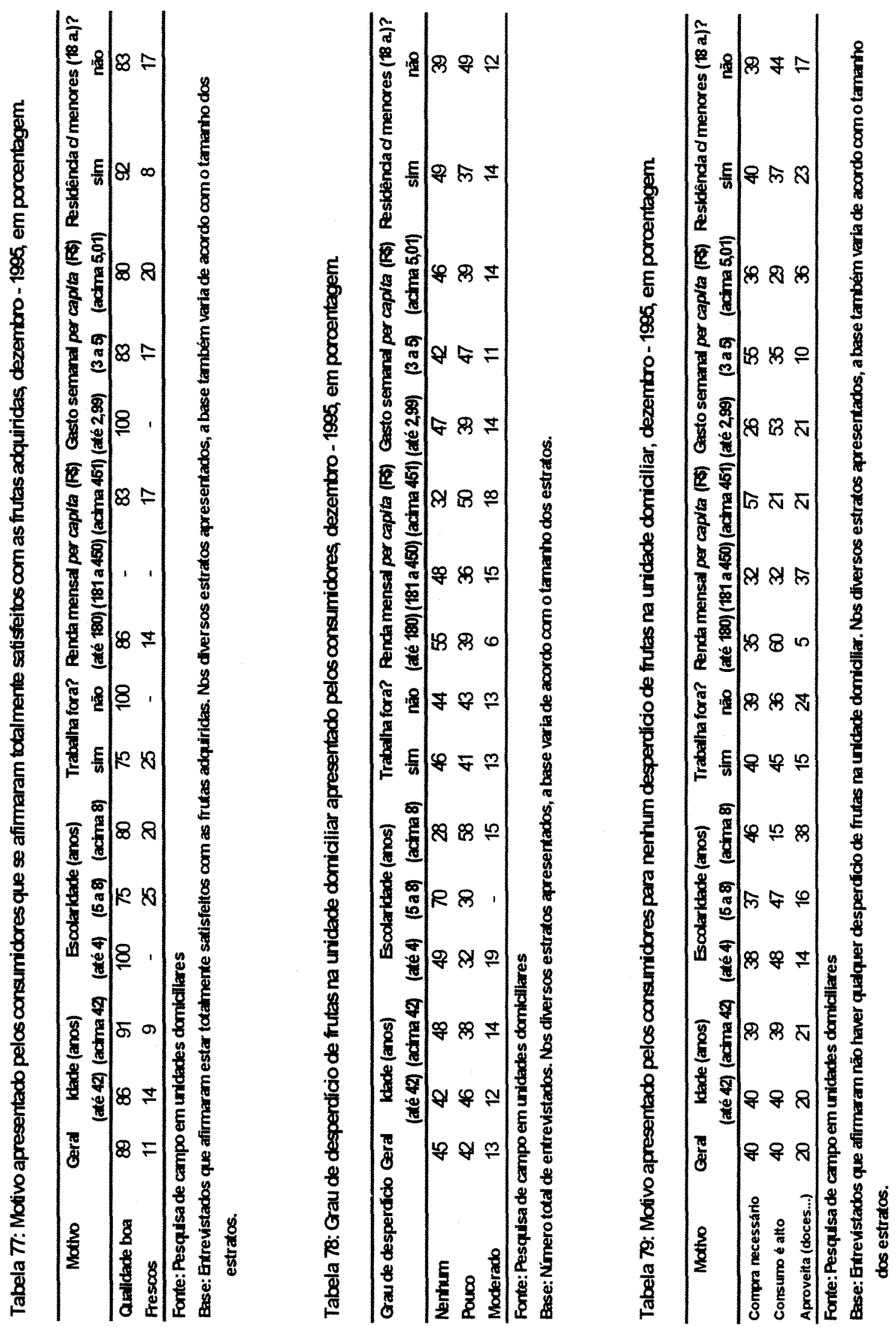
Ao estratificar-se os resultados, ocorrem algumas alterações. As alterações mais interessantes estão relacionadas a grau de escolaridade, fato do indivíduo trabalhar ou não fora e renda per capita.

Os indivíduos com maior grau de escolaridade que afirmaram não ocorrer qualquer desperdício na unidade domiciliar parecem ser motivados a esta resposta pelo fato de comprarem somente o necessário ( $46 \%$ dos entrevistados). Como segundo motivo, apresentaram o fato de aproveitar os produtos quando estes não são consumidos logo (38\% dos entrevistados). Por fim, alguns entrevistados disseram que o motivo foi consumo ser alto (15\%). As demais faixas de escolaridade apresentaram um comportamento parecido, apresentando o motivo consumo alto como principal ( $48 \%$ dos entrevistados da faixa de menor grau de escolaridade e $47 \%$ na faixa intermediária). Em segundo lugar, foi citado o motivo comprar somente o necessário, com $38 \%$ de citações na faixa de menor grau de escolaridade e $37 \%$ na intermediária. Por fim, citou-se o fato de aproveitar os produtos quando estes não são consumidos logo (14\% na faixa de menor grau de escolaridade e $16 \%$ na intermediária)

Em relação ao fato do entrevistado trabalhar ou não fora, as principais alterações ocorreram em relação aos motivos consumo alto e aproveitar os produtos quando estes não são consumidos logo. Conforme esperado, a porcentagem de indivíduos que citou o fato de aproveitar os produtos como motivo da ausência de desperdício foi maior entre os indivíduos que não trabalham fora (citado por $24 \%$ dos entrevistados, contra $15 \%$ entre os indivíduos que trabalham fora). Já o motivo consumo alto, foi mais citado pelos indivíduos que trabalham fora ( $45 \%$ dos entrevistados, contra $36 \%$ entre os indivíduos que não trabalham fora).

Por fim, em relação à renda per capita, houve uma variação grande nos motivos principais. Para os indivíduos com menor renda, o principal motivo da ausência de desperdício foi o fato do consumo ser alto ( $60 \%$ dos entrevistados, contra $32 \%$ na faixa 
intermediária e $21 \%$ na faixa de maior gasto). Já para os indivíduos da faixa de renda intermediária, o principal motivo foi aproveitamento quando o produto não é consumido logo (37\% dos entrevistados, contra $21 \%$ na faixa de maior renda e $5 \%$ na faixa de menor renda). Por fim, para os indivíduos com maior renda, o principal motivo apresentado foi comprar somente o necessário ( $57 \%$ dos entrevistados, contra $32 \%$ na faixa intermediária e $35 \%$ na faixa de menor renda).

Os entrevistados que disseram haver um pouco de desperdício de frutas na unidade domiciliar apresentaram os seguintes motivos para tal: compram somente o necessário ( $30 \%$ dos entrevistados), aproveita o produto para fazer doces quando este não é consumido logo (26\% dos entrevistados), frutas estragam rápido ( $23 \%$ dos entrevistados), consumo é alto ( $16 \%$ dos entrevistados), consumo não é alto ( $2 \%$ dos entrevistados), e deixa muitos restos ( $2 \%$ dos entrevistados), conforme pode ser observado na Tabela 80 . É interessante verificar que os motivos apresentados se dividem em dois tipos, o maior deles tenta justificar o pequeno desperdício apresentando aspectos "positivos" (compra somente o necessário, aproveita o produto antes de estragar e consumo alto), dando a impressão de estar satisfeito com um desperdício pequeno. $O$ outro tipo, por sua vez, parece não estar satisfeito com a presença de desperdício, mesmo que este seja pequeno, apresentando os fatores "negativos" que levam ao mesmo (frutas estragam rápido, consumo não é alto e deixa restos).

Ao realizar a estratificação dos resultados, julgou-se mais proveitoso analisar o padrão de resposta em relação a aspectos "positivos" e "negativos". Neste sentido, os indivíduos do estrato mais novo parecem avaliar a questão pelo lado positivo, com $87 \%$ dos entrevistados apresentando aspectos positivos que justifiquem o pequeno desperdício (contra $55 \%$ no outro estrato). 


$$
\mathbb{1}
$$


Em relação ao grau de escolaridade, a faixa com grau de escolaridade intermediário parece avaliar mais a questão pelo aspecto positivo, com $86 \%$ dos entrevistados apresentando razões positivas para o pequeno desperdício. Em segundo lugar, tem-se a faixa de menor escolaridade, com $75 \%$ dos entrevistados apresentando razões positivas para o pequeno desperdício. Por fim, com $67 \%$ dos entrevistados apresentando razões positivas para o pequeno desperdício, encontra-se a faixa com escolaridade acima de 8 anos de estudo.

$\mathrm{O}$ fato do individuo trabalhar fora também parece fazer com que o indivíduo avalie mais a questão pelo lado positivo, com $89 \%$ dos entrevistados apresentando aspectos positivos que levam ao pequeno desperdício, contra $64 \%$ entre os indivíduos que não trabalham.

Os individuos com menor renda per capita também parecem avaliar a questão pelo aspecto positivo, com $92 \%$ dos entrevistados apresentando razões positivas que levam ao pequeno desperdício. Em segundo lugar, têm-se os indivíduos com renda intermediária, com $69 \%$ dos entrevistados apresentando razões positivas que levam ao pequeno desperdício. Por fim, encontram-se os individuos com maior renda, com $59 \%$ dos entrevistados apresentando razões positivas.

Em relação ao gasto semanal per capita com frutas, os indivíduos com maior gasto parecem avaliar a questão pelo aspecto positivo, com $82 \%$ dos entrevistados apresentando razões positivas que levam ao pequeno desperdício. Em segundo lugar, têm-se os indivíduos da faixa de menor gasto, com $72 \%$ dos entrevistados apresentando razões positivas que levam ao pequeno desperdício. Por fim, encontram-se os indivíduos com gasto intermediário, com $67 \%$ dos entrevistados apresentando razões positivas.

Finalmente, em relação ao fato de haver ou não indivíduos menores de 18 anos na residência do entrevistado, têm-se os indivíduos das unidades domiciliares com 
menores avaliando mais a questão pelo aspecto positivo, com $77 \%$ dos entrevistados apresentando razões positivas que levam ao pequeno desperdício, contra $67 \%$ no outro estrato.

Os entrevistados que disseram haver um grau de desperdício moderado na unidade domiciliar, por sua vez, apresentaram os seguintes motivos: frutas estragam rápido ( $56 \%$ dos entrevistados), consumo não é alto ( $38 \%$ dos entrevistados) e deixa muitos restos ( $6 \%$ dos entrevistados), conforme pode ser observado na Tabela 81 .

Ao realizar-se a estratificação dos resultados, o fato mais interessante a ser analisado é o fato do indivíduo destacar os restos como fonte de desperdício. Neste sentido, em relação à idade do entrevistado, percebe-se que $14 \%$ dos indivíduos mais novos consideraram os restos deixados causadores do desperdício do produto. No outro estrato este aspecto não foi nem mencionado.

Os indivíduos com escolaridade acima de 8 anos também foram os únicos a citar os restos deixados como fonte de desperdício, com 14\% dos entrevistados apresentando este fator como causa do desperdício moderado do produto.

Em relação a renda per capita, apenas os indivíduos da faixa de maior renda citaram os restos deixados como causadores do desperdício (17\% dos entrevistados).

Os indivíduos da faixa de maior gasto semanal per capita com frutas também foram os únicos a citar os restos deixados como fonte de desperdício, com $25 \%$ dos entrevistados afirmando ser este o motivo do desperdício moderado na unidade domiciliar. 

Finalmente, em relação ao fato de haver ou não indivíduos menores de 18 anos na unidade domiciliar, apenas os entrevistados de residências com indivíduos menores apontaram o fato de serem deixados restos como causa do desperdício, com $9 \%$ dos indivíduos afirmando ser esta a causa do desperdício moderado de frutas.

O último item da fase de pós-compra, conforme destacado anteriormente, foi o destino dos resíduos de frutas (cascas, sementes, etc.). Neste sentido, $74 \%$ dos entrevistados afirmaram jogar os resíduos no lixo, 20\% afirmaram tentar aproveitar os resíduos para consumo (fazendo doces ou geléia com as cascas, por exemplo), 3\% disseram usar os resíduos como adubo de plantas e 3\% afirmaram utilizar o produto para alimentação de animais, conforme pode ser observado na Tabela 82 .

A estratificação dos resultados causa algumas alterações no padrão de resposta, conforme pode ser também observado na Tabela 82. O aspecto mais interessante destas alterações está relacionado à porcentagem de indivíduos que tenta aproveitar os resíduos do produto. $O$ aumento da escolaridade dos entrevistados faz com que aumente a porcentagem de indivíduos que tentam aproveitar os resíduos. Da mesma maneira, o aumento da renda per capita e do gasto semanal per capita com frutas também fazem com que se eleve a porcentagem de indivíduos que tentam aumentar o aproveitamento dos resíduos de frutas. 
188

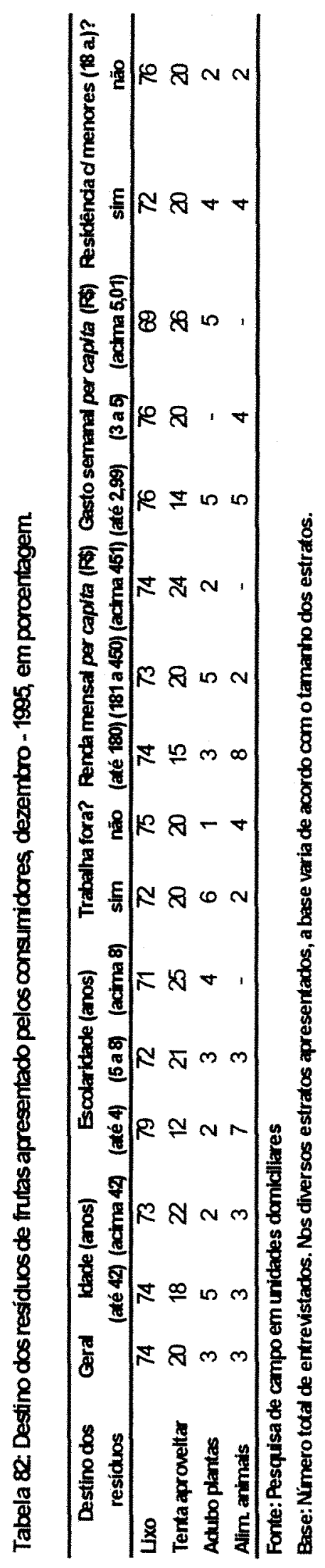




\section{CONCLUSÕES}

Conforme mencionado anteriormente, foram discutidas as diversas fases do consumo de frutas com base no modelo de comportamento do consumidor proposto neste trabalho. Com base neste modelo, pode-se caracterizar cada fase do consumo de frutas, cujas conclusões finais são apresentadas a seguir.

\subsection{Pré-compra}

Seguindo o modelo proposto, a fase de pré-compra foi discutida em três frentes: influências externas, influências internas e processo de tomada de decisão.

As influências externas foram analisadas em relação às atividades de marketing das empresas e influências socioculturais.

Em relação às atividades de marketing das empresas, foram analisados fatores relacionados ao produto, como embalagem, e às atividades promocionais.

Conforme tendência levantada na revisão de literatura, os consumidores entrevistados também preferem adquirir produtos a granel, principalmente devido a possibilidade de escolher melhor o produto. Quando a opção foi por produtos embalados ou ambos os tipos (embalado e granel), os motivos apresentados foram, respectivamente, qualidade do produto e disponibilidade. 
Quando foram analisadas as atividades promocionais percebidas pelos consumidores, verificou-se que a maioria dos indivíduos entrevistados não notou qualquer tipo de atividade promocional relacionada às frutas a serem adquiridas. Entre os individuos que notaram alguma atividade promocional foram destacadas os seguintes itens, em ordem decrescente de importância: descontos, propagandas (jornais, revistas, rádio e televisão), cartazes, folhetos, experimentações gratuitas, outdoors e propaganda sonora na rua. Essa pequena percepção de atividades promocionais pode ter sido causada pelo fato do item frutas não ser alvo de promoções tão constantes, como ocorre com outros produtos.

As influências socioculturais parecem interferir no comportamento de consumo dos indivíduos entrevistados, uma vez que foram verificadas, no decorrer da apresentação dos resultados, a ocorrência de inúmeras variações no padrão de resposta devido à estratificação dos resultados por fatores como renda, educação, ocupação e idade.

As influências internas foram analisadas em relação ao risco percebido e ao conjunto evocado.

Conforme ressaltado anteriormente, o risco percebido, no caso de produtos alimentícios, está intimamente relacionado a riscos à saúde devido à contaminação de alimentos e ingestão de alimentos saudáveis. Assim sendo, analisou-se o padrão de comportamento dos indivíduos entrevistados em relação a fatores como motivos de consumo de frutas, preocupações com a saúde interagindo com o consumo de frutas, preocupações com resíduos químicos e consumo de produtos orgânicos.

O principal motivo de consumo de frutas apresentado foi a saúde, seguido do sabor, com a dieta na terceira colocação, confirmando tendência levantada na revisão de literatura. 
Para confirmar esta tendência, os indivíduos entrevistados também foram inquiridos a respeito da influência das preocupações com a saúde sobre o consumo de frutas. Neste sentido, a maioria dos entrevistados disse que esta influência ocorre. Os motivos apresentados para isso foram, em ordem decrescente de importância: presença de vitaminas, frutas "fazem bem" - sem saber ao certo o motivo e auxilio à digestão/ funcionamento do intestino. Isso comprova que, embora o consumidor não tenha um conhecimento apurado das vantagens à saúde advindas do consumo de frutas, ele tende a consumir esse produto devido aos benefícios os quais julga que o consumo do produto traz à sua saúde.

Em relação a presença de resíduos químicos nas frutas adquiridas, a maioria dos entrevistados afirmou se preocupar com o assunto. Entre os indivíduos que afirmaram estar preocupados com os resíduos, a maioria diz que lava bem ou descasca os alimentos para diminuir os riscos. Um segundo grupo se diz preocupado, mas afirma que não há o que fazer em relação a isso. Embora este resultado demonstre uma preocupação dos consumidores entrevistados com a presença de resíduos químicos nos alimentos, estes consumidores parecem conformados em relação a esse problema. Isso pode ser ressaltado pelos resultados da pesquisa, os quais mostram medidas paliativas, como lavar e descascar os alimentos ou simplesmente consumi-los, por não ter outra opção.

O consumo de produtos orgânicos também foi avaliado. Neste aspecto, notou-se um resultado surpreendente, uma vez que mais da metade dos entrevistados afirmou já ter consumido este tipo de produto. Este resultado difere do encontrado na revisão de literatura, que destaca o mercado de produtos orgânicos como um mercado com grande potencial de crescimento, mas ainda em desenvolvimento, mesmo em países desenvolvidos.

O principal motivo apresentado pelos consumidores entrevistados para o consumo de produto orgânico foi a disponibilidade de produtos oriundos de pomares 
"próprios/ caseiros", onde não seriam usados produtos químicos, podendo ser esta a explicação para este resultado inesperado. Em relação aos entrevistados que afirmaram nunca ter consumido produto orgânico, o motivo apresentado foi indisponibilidade deste tipo de produto, o que realmente pode ser notado quando analisada a disponibilidade de produtos deste tipo nos pontos de venda.

Conforme ressaltado anteriormente, o conjunto evocado foi analisado em três frentes: frutas preferidas, frutas adquiridas e frutas rejeitadas. As frutas preferidas pelos indivíduos entrevistados foram, em primeiro lugar a laranja, em segundo a melancia e em terceiro a banana. As frutas efetivamente compradas, por sua vez, foram, em primeiro lugar a laranja, em segundo a banana e em terceiro a maçã. Conforme pode ser observado, existe uma relação estreita entre as frutas preferidas e as efetivamente adquiridas. Já em relação às frutas rejeitadas, a maioria dos entrevistados rejeitou pelo menos um tipo de fruta. Quando ocorre a rejeição, a distribuição é equilibrada entre os diversos tipos rejeitados, mas pode-se destacar alguns, como: jaca, melão, kiwi e abacate. Embora os dados analisados na revisão de literatura sejam escassos e estejam relacionados apenas às frutas compradas, pode-se notar uma coincidência entre os resultados da pesquisa de campo e da POF (1991).

A terceira e última frente da fase de pré-compra está relacionada ao processo de tomada de decisão. Este processo, por sua vez, se divide em três fases: reconhecimento do problema, busca de informações e avaliação das alternativas.

O reconhecimento do problema foi relacionado às diversas maneiras de utilização do produto. Neste sentido, verificou-se que a principal maneira de utilização do produto é in natura. As frutas preferidas, neste caso, foram: banana, laranja e maçã, em ordem decrescente de importância. Em segundo lugar, o produto é utilizado na forma de suco, sendo os tipos preferidos a laranja, em primeiro lugar, seguida de maracujá, limão e abacaxi. Finalmente, em terceiro lugar, o produto é utilizado como ingrediente de outros 
pratos. Neste caso, preferiu-se tipos como banana, maçã e laranja, em ordem decrescente de importância.

Para complementar a análise da fase de reconhecimento do problema, também foi verificado se os entrevistados escolhem o tipo de fruta pensando no uso que as mesmas terão. Neste aspecto, notou-se que a maioria dos indivíduos afirmou não escolher o tipo de fruta pensando no uso que a mesma terá. Isso pode parecer em desacordo em relação aos dados anteriores, que revelam opções por diferentes tipos de produtos de acordo com o uso dos mesmos. No entanto, o processo de escolha dos produtos pode ser bastante automático, com a escolha dos produtos a serem consumidos ocorrendo em fase posterior.

Em relação à busca de informações, foi analisado o grau de confiança dos indivíduos entrevistados em relação a diversas possiveis fontes de informação. Assim sendo, verificou-se que as fontes de informação são classificadas na seguinte ordem decrescente de confiança: médico, nutricionista, livros, clínicas, escolas, amigos e família, programas de TV, governo, artigos de revista, artigos de jornal, comentários de rádio, propagandas na TV, propagandas em jornal, propagandas em revistas e propagandas no rádio. Conforme destacado na revisão de literatura, os consumidores entrevistados também confiam mais em fontes não comerciais de informação.

Em relação à última fase do processo de tomada de decisão, a avaliação de alternativas, foram analisados os atributos considerados mais importantes pelos indivíduos entrevistados. Assim sendo, foi obtida a seguinte classificação (em ordem decrescente de importância): frescor, saudável, firmeza, sabor, segurança, aparência, cor, valor nutritivo, preço, selo de qualidade, variedade/ tipo, efeito ambiental, local de produção, embalagem, tamanho e marca. De maneira geral, estes resultados são coerentes em relação aos das pesquisas encontradas na revisão de literatura. 


\subsection{Compra}

De acordo com o modelo proposto, a fase de compra se divide em três frentes: situação de compra, local de aquisição e atores no processo de compra.

A situação de compra, por sua vez, foi analisada em relação a ambiente de informação, ambiente de ponto de venda e influência temporal.

Em relação ao ambiente de informação, foram analisados os tipos de informações que os entrevistados gostariam de ter disponíveis no momento da compra. Neste sentido, a maioria dos entrevistados disse estar satisfeita com as informações atuais, não desejando qualquer tipo de informação adicional. Entre os insatisfeitos com as informações disponíveis atualmente, foram citadas vários tipos informações desejados. Os principais são: produtos químicos presentes nos produtos, procedência, data de colheita/ validade, vitaminas, em ordem decrescente de importância.

$\mathrm{O}$ ambiente de ponto de venda também foi avaliado em relação aos seus atributos considerados mais importantes pelos entrevistados. Os atributos apresentados foram classificados na seguinte ordem decrescente de importância: limpeza, apresentação dos produtos, ausência de odores, espaço disponível para circulação, sistema de pesagem e vendedores. Este resultado ressalta a importância da limpeza na escolha do local de compra, tendência encontrada na revisão de literatura.

Finalmente, em relação ao terceiro ponto da situação de compra, a influência temporal, foi avaliado o tempo disponivel e a sazonalidade/época do ano. A maioria dos indivíduos entrevistados disse não sofrer influência do tempo disponível no momento da compra, pois afirma ter prática com a tarefa ou só se dedicar a isso quando dispõe de tempo. Os indivíduos que disseram sofrer pressões temporais, por sua vez, afirmaram que 
as consequêencias da limitação de tempo são: não escolhe bem, limitação da escolha a tipos comuns e limitação dos locais de compra aos mais convenientes.

Em relação à sazonalidade, a maioria dos entrevistados disse adquirir frutas da estação. Os motivos apresentados para a compra deste tipo de produto foram, em ordem decrescente de importância: preço, qualidade, disponibilidade, produto mais fresco, sabor, produto mais saudável e possibilidade de variar tipos de frutas consumidos.

A escolha dos locais de aquisição também foi avaliada. Os indivíduos entrevistados classificaram os locais de escolha na seguinte ordem decrescente de importância: sacolões/varejões, supermercados, feiras, lojas de frutas, mercado municipal, vendedores ambulantes, produtor, armazém, bar e ESALQ (pomar da universidade). Comparando estes resultados com os encontrados na revisão de literatura, pode-se notar o aparecimento de um novo tipo de ponto de venda para aquisição de frutas - os sacolões/varejões - os quais não aparecem nas pesquisas analisadas (POF e ENDEF) e foram considerados o principal local de compra pelos consumidores entrevistados. Os supermercados, por sua vez, aparecem na segunda posição, confirmando importância cada vez maior deste tipo de local de compra para aquisição de diversos tipos de produto, encontrada em diversos estudos.

Os motivos apresentados para escolha do local de compra também foram levantados. São eles: variedade de produtos, praticidade/facilidade, produtos mais frescos, localização, preço, qualidade dos produtos, ambiente mais agradável, horário de funcionamento, costume e confiança, em ordem decrescente de importância.

Para complementar a análise da fase de compra, foram analisados os atores participantes no processo de compra. Neste sentido, foram avaliados o processo decisório e o processo de compra propriamente dito. Em ambos os casos, o entrevistado aparece como principal ator envolvido no processo. Vale salientar que, tanto no processo 
de decisão como de compra, o entrevistado foi, na maioria dos casos, o único responsável. Tendo em vista que a maioria dos entrevistados era mulher, tem-se uma confirmação dos dados encontrados na revisão de literatura, que ressaltam a importância da mulher em relação ao processo de compra (decisão e compra propriamente dita).

\subsection{Pós-compra}

Segundo o modelo proposto, a fase de pós compra pode ser dividida em três frentes: pré-consumo, onde são avaliados itens como armazenamento e preparo do produto, consumo propriamente dito, onde avaliam-se diversas situações de consumo, $\mathrm{e}$ pós-consumo, onde são avaliadas as sensações pós-consumo. Também foi feita uma análise do item descarte, considerado importante para o produto em questão.

Para analisar o pré-consumo, foi feita uma avaliação do armazenamento das frutas nas unidades domiciliares pesquisadas. Neste sentido, verificou-se que grande parte dos entrevistados armazena o produto dentro e fora da geladeira, dependendo do tipo de fruta. Outra parte, apenas um pouco menor, costuma armazenar o produto somente na geladeira. Por fim, apenas uma pequena parte dos consumidores armazena o produto somente fora da geladeira.

Em relação ao preparo do produto, verificou-se que a maioria dos indivíduos entrevistados costuma preparar o produto com maior freqüência (sempre ou freqüentemente).

O consumo propriamente dito foi avaliado sob o enfoque das diversas situações de consumo. Assim sendo, foi verificado se a situação de uso interferia, na opinião dos entrevistados, no tipo de fruta a ser escolhido. $O$ resultado da pesquisa mostrou que a maioria dos entrevistados não acha que a situação de consumo influi no tipo de fruta a ser escolhido. Este resultado é um pouco surpreendente em relação ao que seria esperado. 
No entanto, é importante salientar que não foi encontrado nenhum estudo que tratasse especificamente da influência das diversas situações de uso no comportamento de consumo para $o$ item frutas.

Ainda em relação às diversas situações de consumo, o tempo no qual o uso ocorre também foi avaliado. Neste sentido, avaliou-se o consumo ou não de frutas em diversas situações temporais, assim como os tipos de frutas consumidos em cada uma delas.

Avaliando a porcentagem de respostas positivas em relação ao consumo de frutas, verificou-se, na amostra pesquisada, um consumo maior de frutas nas seguintes situações (em ordem decrescente de importância): sobremesa do almoço, lanche durante a tarde, lanche durante a manhã, sobremesa do jantar, café da manhã e lanche antes de dormir. Vale salientar que, em todas as situações, mais da metade dos indivíduos entrevistados afirmou consumir o produto.

Em relação aos tipos de frutas consumidos em cada situação, os entrevistados destacaram os seguintes tipos (sempre em ordem decrescente de importância): café da manhã: mamão, laranja e maçã; lanche durante a manhã: maçã, laranja e banana; sobremesa do almoço: laranja, banana e maçã; lanche durante a tarde: maçã, banana e laranja; sobremesa do jantar: laranja, banana e maçã; lanche antes de dormir: maçã, laranja e mamão. Pode-se perceber que, embora ocorram variações na ordem de preferência, os tipos de frutas consumidos em lanche durante a manhã, sobremesa do almoço, lanche durante a tarde e sobremesa do jantar são os mesmos. O mesmo ocorre em relação ao café da manhã e lanche antes de dormir.

Estes resultados também foram encontrados na revisão de literatura, em estudo específico sobre frutas. Neste estudo, ressaltou-se ainda a ocorrência de variações na preferência pelo tipo de fruta decorrentes do tipo de consumidor. Estas variações também 
foram percebidas na pesquisa de campo, uma vez que os resultados foram estratificados. Isso vem a reforçar a opção pela adoção da visão interacionista, segundo a qual o comportamento de consumo sofre influência da situação, do indivíduo e da interação situação/indivíduo.

O pós-consumo, conforme mencionado anteriormente, foi avaliado através das sensações pós-consumo. Neste sentido, verificou-se o grau de satisfação dos indivíduos entrevistados em relação às frutas adquiridas. A maioria dos entrevistados afirmou estar bastante ou totalmente satisfeita com os produtos adquiridos, principalmente devido à boa qualidade dos produtos. Um segundo grupo afirmou estar moderadamente satisfeito, apresentando como motivo principal a má qualidade dos produtos consumidos. Por fim, uma pequena parte dos entrevistados afirmou estar pouco satisfeita com as frutas consumidas, principalmente devido a má qualidade das mesmas.

$\mathrm{O}$ último item do pós-consumo, considerado bastante importante para o produto em questão, foi o descarte. Para avaliar este item, foi verificado o grau de desperdício do produto nas unidades domiciliares pesquisadas, assim como o destino dos resíduos de frutas, como cascas, sementes etc.

A maioria dos entrevistados afirmou que não ocorre qualquer desperdício na unidade domiciliar, devido, principalmente, ao consumo ser alto e ao fato de ser comprada uma quantidade adequada do produto. Um segundo grupo afirmou que ocorre um pequeno desperdício. Neste grupo, foi observado um resultado interessante. A maioria dos entrevistados julgou que um pequeno desperdício seria positivo, apresentando motivos como: comprar somente a quantidade necessária, aproveitar o produto antes de estragar e consumo alto. A outra parte dos entrevistados considerou negativo o fato de haver um pequeno desperdício, apresentando motivos como: frutas estragam rápido, consumo baixo e fato de serem deixados muitos restos. Finalmente, um pequeno grupo de indivíduos afirmou ocorrer um desperdício moderado de frutas na 
unidade domiciliar, devido ao fato das frutas estragarem rápido, ao consumo não ser alto e ao fato de serem deixados muitos restos.

Em relação ao destino dos resíduos, detectou-se que a grande maioria dos entrevistados simplesmente joga-os no lixo. Um segundo grupo tenta aproveitar os resíduos para fazer outros pratos, como doces, geléias etc. Finalmente, também existem alguns individuos que usam os resíduos para adubar plantas ou alimentar animais.

\subsection{Modelo}

Conforme destacado anteriormente, o objetivo geral deste estudo é apresentar um modelo de comportamento de consumo adaptado para o item frutas, obtendo, com a ajuda desta estrutura, uma caracterização mais adequada de cada fase do processo de consumo deste tipo de produto.

É importante ressaltar que o modelo proposto ressalta a fase de pós-consumo, considerada muito importante para o estudo do produto em questão. Isso ocorre pois há maior destaque do item descarte, muito importante no caso de um produto perecivel, como as frutas. Além disso, é muito importante que o estudo do comportamento dos consumidores não se encerre após a compra, uma vez que o consumo e as sensações pósconsumo são muito importantes para determinar comportamentos futuros.

Conforme pode ser avaliado pelos resultados obtidos na pesquisa de campo, a estrutura utilizada para estudo do comportamento de consumo, baseada no modelo simplificado proposto, permitiu uma caracterização adequada do comportamento de consumo em relação ao item frutas. 


\section{SUMÁRIO, LIMITAÇÕES E PESQUISAS FUTURAS}

O presente estudo está centrado no processo de tomada de decisão de consumo, em relação a frutas in natura, com foco no consumo domiciliar.

Com este objetivo foi feita uma revisão bibliográfica sobre o processo de consumo, com a apresentação de alguns modelos considerados relevantes para o estudo em questão. Além disso, também foi realizada uma pesquisa bibliográfica sobre características específicas do consumo de frutas.

A partir deste referencial teórico foi proposto um modelo simplificado para servir como base ao estudo (Figura 6). Também foram sugeridos elementos relevantes ao processo específico de consumo de frutas. Com estes subsídios, realizou-se uma pesquisa exploratória de campo, através de entrevistas, com o objetivo de testar o modelo, verificando se o mesmo permite uma caracterização adequada do processo de consumo deste tipo de produto.

Uma melhor caracterização do consumo, pode vir a trazer beneficios aos produtores deste setor, pois estes conhecerão melhor seu consumidor final, aos varejistas que comercializam este tipo de produto, que teriam maior conhecimento do processo de consumo, assim como aos consumidores finais, a medida que poderiam ter suas necessidades atendidas de maneira mais satisfatória. 
Espera-se, com este estudo, fornecer apenas um melhor direcionamento em relação à compreensão do processo de consumo de frutas. Esta limitação é oriunda da própria metodologia utilizada para realização da pesquisa, ou seja, pesquisa exploratória, com estudo de um pequeno grupo de unidades domiciliares. Desta forma, o resultado obtido permite apenas uma melhor caracterização do problema. A opção por este tipo de estudo está relacionada à ausência de trabalhos brasileiros especificamente voltados para o tema.

Para que fossem obtidos resultados mais apurados, que pudessem ser generalizados, o ideal seria fazer este tipo de pesquisa em diversos locais, com número significativo de entrevistas, permitindo avaliações estatísticas mais elaboradas. No entanto, conforme mencionado anteriormente, o objetivo do presente estudo não foi este.

Outro fato que pode causar algumas alterações em estudos como este está relacionado a época de aplicação das entrevistas. A época do ano pode causar interferência em relação aos tipos de frutas mencionados, uma vez que grande parte dos produtos apresenta uma sazonalidade de produção, estando disponíveis, em maior quantidade, em determinadas épocas do ano. Esta limitação não foi tão grave, no presente estudo, pois as frutas mais mencionadas estão disponíveis aos consumidores praticamente durante $o$ ano todo.

Quanto às entrevistas realizadas, houve uma pequena dificuldade em relação à duração da mesma (aproximadamente 30 minutos), causando uma certa impaciência em alguns indivíduos entrevistados. Este fato não chegou a causar graves problemas no conteúdo das entrevistas, uma vez que, conforme mencionado anteriormente, as questões sócio-demográficas foram alocadas no final do questionário. Este tipo de questão é mais facilmente respondido, mesmo quando o entrevistado se encontra cansado. 
O objetivo deste estudo foi, portanto, realizar um levantamento inicial que sirva como ponto de partida e estímulo a um maior aprofundamento sobre o assunto. Isso poderia ser obtido através da realização de pesquisas mais amplas, que permitam generalização dos resultados. 


\section{REFERÊNCIAS BIBLIOGRÁFICAS}

ACKOFF, R. L. Planejamento de pesquisa social. São Paulo: Herder; EDUSP, 1967. $556 \mathrm{p}$.

ARAÚJO, N. B. de; WEDEKIN, I.; PINAZZA, L. I. Complexo agro-industrial: o "agribusiness" brasileiro. São Paulo: Agroceres, 1991. 238 p.

BARKEMA, A.D. New roles and alliances in the U.S. food system. Presented at the Spring Meeting of the Federal Reserve System Committee on Agriculture and Rural Development, Missouri, 1993.29 p.

BELK, R.W. An exploratory assessment of situational effects in buyer behavior. Journal of Marketing Research, v. 11, p. 156-163, May 1974.

BENNETT, S. Produce power play. Progressive Grocer, p. 83-87, Nov. 1993.

BENNETT, S. On the cutting edge. Progressive Grocer, p. 87-94, Feb. 1994a.

BENNETT, S. Produce aplenty. Progressive Grocer, p. 86, Feb. 1994 b.

BENNETT, S. The information age. Progressive Grocer, p. 97-100, Mar. 1994c. 
BENNETT, S. Handle with care. Progressive Grocer, p. 79-80, Jun. 1994d.

BENNETT, S. Specialty produce needs special attention. Progressive Grocer, p. 139142, Aug. 1994e

BRASIL. Ministério da Agricultura e Reforma Agrária. Programa de Apoio à Produção e Exportação Frutícola. O setor de produção de frutas frescas no contexto da economia agrícola brasileira. Brasília: FRUPEX, 1992. 27p.

BYRNE, P.; TOENSMEYER, U. Analysis of consumer attitudes concerning food safety and fresh produce in Delaware and the Delmarva Region. Delaware: University of Delaware, 1993. 130 p. (Agricultural Experiment Station Bulletin, n. 497).

CANNON, T. Patterns of innovation and development in the food chain, 1992. 13p.

CARRARO, A.F.; CUNHA, M.M. da. Manual de Exportação de Frutas. Brasília: MAARA-SDR-FRUPEX/IICA, 1994. 252 p.

COZINHA INDUSTRIAL. São Paulo, v. 2, n. 11, p. 44-47, 1990.

DARRALL, J. The response of the food chain to healthy eating. British Food Journal, v. 94, n. 4 , p. $7-11,1992$.

DICKSON, P.R. Person-Situation: Segmentation's Missing Link. Journal of Marketing, v. 46, p. $56-64,1982$.

DIREITOS DO CONSUMIDOR. Lei N ${ }^{\circ} 8.078$, de 11/9/1990. 3. Ed. São Paulo: Editora Cone, $1991.77 \mathrm{p}$. 
ELMAN, L.G. 5 a day: is it working? Progressive Grocer, p. 73-76, Dec. 1993.

ESTUDO NACIONAL DA DESPESA FAMILIAR. Consumo alimentar, despesas das famílias: tabelas selecionadas, Rio de Janeiro: IBGE, 1978.

ESTUDO NACIONAL DA DESPESA FAMILIAR. Consumo Alimentar Antropometria, Regiōes II e IV, Rio de Janeiro: IBGE, 1977.

ENGEL, J.F.; BLACKWELL, R.D.; MINIARD, P.W. Consumer Behavior. 7. ed., Dryden Press, 1993. 846 p.

FAZIO, G. Produção e consumo de frutas "in natura". Revista da Administração, v. 29, n. 1, p. 83-88, Jan./Mar. 1994.

FEEDBACK SERVIÇOS DE PESQUISA. Pesquisa sobre o consumo de alimentos. São Paulo, encomendada pela Revista Superinteressante, 1991.

GRUNET, S.C. Everybody seems concerned about the environment. But is this concern reflected in (Danish) consumers' food choice? ØFP Working Paper n.4, Jun., 1992. $13 \mathrm{p}$.

GRUNET, S.C.; KRISTENSEN, K. Factors influencing consumers' demand for organically produced foods: theoretical notes and project outline. ØFP Working Paper n.1, Nov. 1990. 24 p.

KIDDER, L. H. (Org.). Métodos de pesquisa nas relações pessoais. 4. ed.. São Paulo: EPU, 1987a. v. 1.117 p. 
KIDDER, L. H. (Org.). Métodos de pesquisa nas relações pessoais. 4. ed.. São Paulo: EPU, 1987b. v. 2. 133 p.

KOTLER, P. Administração de marketing: análise, planejamento, implementação e controle. 2. ed. São Paulo: Atlas, 1992. 848 p.

MANCHESTER, A. C. Rearranging the economic landscape: the food marketing revolution, 1950-91. Washington: USA, Commodity Economics Division, Economic Research Service, USDA, 1992. 165 p.

MARCONI, M. de A.; LAKATOS, E.M. Técnicas de pesquisa: planejamento e execução de pesquisas, amostragens e técnicas de pesquisa, elaboração, análise e interpretação de dados. 2. ed., São Paulo: Atlas, 1990. 231 p.

MEJIDO, J.L.T:; XAVIER, C. Marketing \& Agribusiness. São Paulo: Atlas, 1993. $202 \mathrm{p}$.

MEULEMBERG, M. T.; TRIJP, J. C. M. Van. Consumers store choice behavior for fresh food. Wageningen, Netherlands: Wageningen Agricultural University, 1991. p. 77-91.

MILLER, D.C. Handbook of research design and social measurement. 3. ed. . New York: Longman. 1977.

MILLER, K.E.; GINTER, J.L. An Investigation of Situational Variation in Brand Choice Behavior and Attitude. Journal of Marketing Research, v. 16, p. 111-123, Feb. 1979. 
NOGUEIRA, W. Know-how e qualidade conduzem ao lucro. Superhiper, p. 156-162, Out. 1989.

O NOVO Perfil do Consumidor. Superhiper, p. 89-113, Fev. 1992.

PERRIEN, J., coord.. Recherche en marketing - méthodes et décisions. Canada: Gaéton Morin Éditeur, 1984.

PESQUISA NACIONAL POR AMOSTRA DE DOMICÍLIOS - PNAD. Rio de Janeiro: IBGE, v. 3, t. 2,1980a.

PESQUISA NACIONAL POR AMOSTRA DE DOMICÍLIOS - PNAD. Rio de Janeiro: IBGE, v. 4, t. 2, 1980b.

PESQUTSA NACIONAL POR AMOSTRA DE DOMICÍLIOS - PNAD. Rio de Janeiro: IBGE, v. 5, t. 6, 1983a.

PESQUISA NACIONAL POR AMOSTRA DE DOMICÍLIOS - PNAD. Rio de Janeiro: IBGE, v. 6, t. 4,1983b.

PESQUTSA NACIONAL POR AMOSTRA DE DOMICÍLIOS - PNAD. Rio de Janeiro: IBGE, v. 8, t. 5,1985.

PESQUISA NACIONAL POR AMOSTRA DE DOMICÍLIOS - PNAD. Rio de Janeiro: IBGE , v. 10, t. 5,1988a.

PESQUISA NACIONAL POR AMOSTRA DE DOMICÍLIOS - PNAD, Rio de Janeiro: IBGE, v. 11, t. 5,1988b. 
PESQUISA NACIONAL POR AMOSTRA DE DOMICÍLIOS - PNAD. Síntese de Indicadores da Pesquisa Básica da PNAD de 1981-1989. Rio de Janeiro: IBGE, 1990a. 96 p.

PESQUISA NACIONAL POR AMOSTRA DE DOMICÍLIOS - PNAD. Rio de Janeiro: IBGE, v. 12, t. 5,1990b.

PESQUISA NACIONAL POR AMOSTRA DE DOMICÍLIOS - PNAD. Síntese de Indicadores da Pesquisa Básica 1990. Rio de Janeiro: IBGE, 1993. 121p.

PESQUISA NACIONAL POR AMOSTRA DE DOMICÍLIOS - PNAD / FIBGE. Síntese de Indicadores 1993. Rio de Janeiro: IBGE, 1996. 164p.

PESQUISA NACIONAL POR AMOSTRA DE DOMICÍLIOS - PNAD / FIBGE. Resultados preliminares - Brasil - 1995. Rio de Janeiro: IBGE, 1995.

PESQUISA DE ORÇAMENTOS FAMILIARES - POF/ 1987/88, Rio de Janeiro: IBGE, 1991.

PIRACICABA. Secretaria Municipal de Planejamento. Divisão de Banco de Dados Sócio-Econômico. Perfil sócio-econômico do Município de Piracicaba - 1995. Piracicaba: SEMUPLAN, 1996. 60 p.

PROGRAMA DE APOIO À PRODUÇÃO E EXPORTAÇÃO DE FRUTAS, O setor de frutas frescas no contexto da economia agrícola brasileira. Brasilia: FRUPEX, 1992. $27 \mathrm{p}$.

PUNJ, G.H.; STEWART, D.W. An interaction framework of consumer decision making. Journal of Consumer Research, v. 10, p. 181-196, Sep. 1983. 
REVISTA SUPERINTERESSANTE, jun., 1991.

REVISTA SUPERINTERESSANTE, jul., 1991.

REVISTA SUPERINTERESSANTE, ago., 1991.

SANTOS, R. da C. Marketing e as questões ambientais. Mercado Global, n. 94, p.2835,1994 .

SECRETARIA DE AGRICULTURA E ABASTECIMENTO DE SÃO PAULO, Coordenadoria de Abastecimento, Perfil dos hortigranjeiros comercializados no E.T.S.P.- frutas - 1990. São Paulo, 1992. 191 p.

SEIBEL, W. Einfluß von Verbraucher und Handel auf die Qualität landwirtschaftlicher Produkte und Lebensmittel. VDLUFA Schriftenreihe, 32 - Kongreßband, s. 107-127, 1990.

SCHIFFMAN, L.G.; KANUK, L.L. Consumer Behavior. 5. ed. Englewood Cliffs: Prentice Hall, 1994. 684 p.

SHETH, J.N. Models of buyer behavior: conceptual, quantitative $\boldsymbol{\&}$ empirical. New York: Harper \& Row, 1974.

STAYMAN, D.M.; DESHPANDE, R. Situational ethnicity and consumer behavior. Journal of Consumer Research, v. 16, p. 361-371, Dec. 1989.

SUPERHIPER, p. 108, fev. 1994a.

SUPERHIPER, p. 128, jun. 1994b. 
SUPERMERCADO MODERNO, p.12, nov. 1991a.

SUPERMERCADO MODERNO, p.32, nov, 1991b.

VON ALVENSLEBEN, R.; MEIER, T. The influence of origin and variety on consumer perception. Acta Horticulturae, v. 259, p. 151-161, 1990.

WEERSINK, J.; ALLAN, S.; FUNK, T.; GODDARD, E. Consumers' nutritional attitudes and perceptions: a pilot study. University of Guelph, 1990. 36p. (Working paper WP90/26).

WHEELOCK, J.V. Food quality and consumer choice. British Food Journal, v. 94, n. 3, p.39-43, 1992 


\section{APÊNDICE 1}

Formulário para entrevistas 
Nome do entrevistado:

\section{I.) Pré-compra}

1. Em relação ao consumo de frutas, que tipo de consumidor você se considera?

( ) Habitual (compra frutas habitualmente)

( ) Esporádico (compra frutas de vez em quando)

2. Em relação à embalagem, que tipo de frutas você costuma adquirir?

( ) Embalado (filme plástico, bandeja, etc.)

( ) Granel

3. Por que?

\begin{tabular}{|ll}
( & ) higiene \\
( & ) aparência \\
( & ) qualidade \\
( & ) possibilidade de escolha \\
( & ) porção adequada \\
( & ) preço
\end{tabular}

4. Que tipo de atividades promocionais, em relação ao item frutas, você tem observado, com maior freqüência, nos últimos tempos? - USAR CARTÃO 1

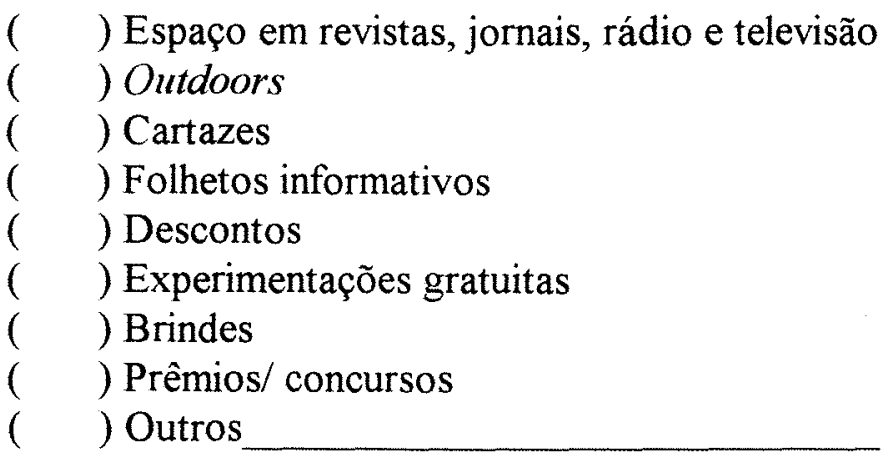


5. Por que você consome frutas? (Explorar)

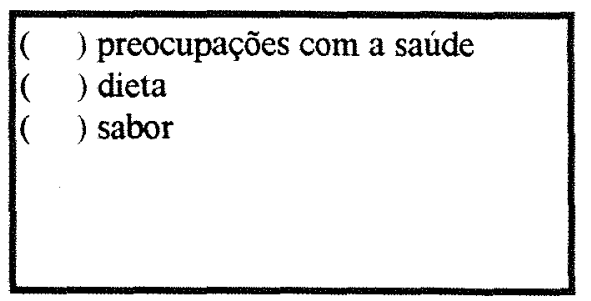

6. Preocupações com a saúde estimulam ou não o consumo de frutas?

$$
\begin{aligned}
& \text { ( ) Não } \\
& \text { ( ) Sim }
\end{aligned}
$$

Explique:

7. Existe algum outro tipo de preocupação em relação ao consumo de frutas frescas, como ingestão de resíduos químicos, por exemplo?

8. Você já consumiu algum tipo de fruta produzido organicamente?

$$
\begin{aligned}
& \text { ( ) Não } \\
& \text { ( ) Sim }
\end{aligned}
$$

Por que?

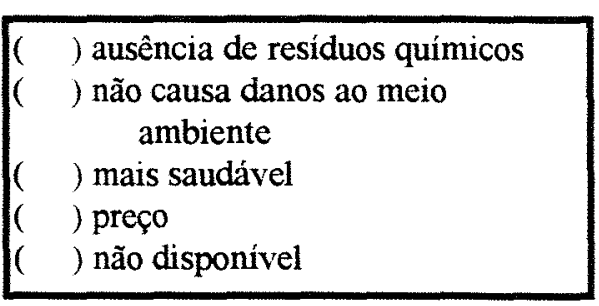


9. Que tipo de frutas você prefere consumir? Quais são as mais preferidas? (Citar pelo menos três tipos) - USAR CARTÃO 2

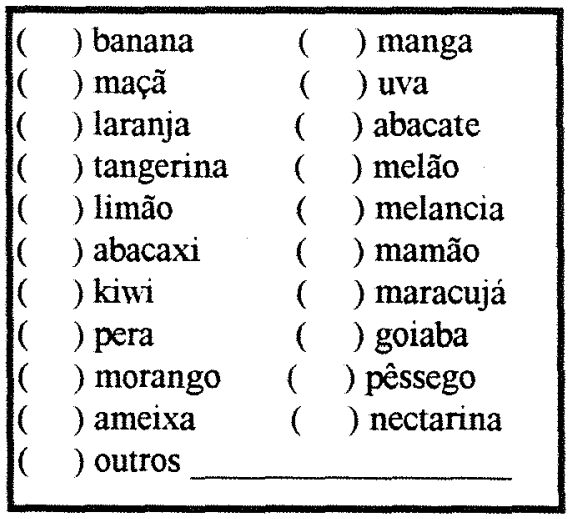

10. Que tipo de frutas você comprou nos últimos seis meses? Quais são os mais importantes? (Citar pelo menos três tipos) - USAR CARTÃO 2

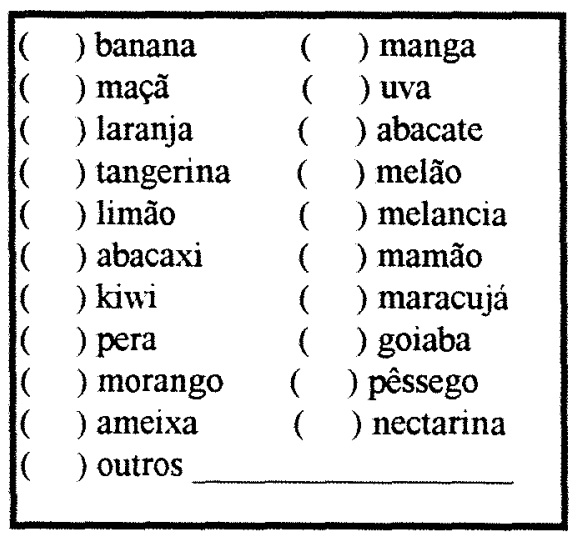

11. Você não consome alguma(s) fruta(s)? - USAR CARTÃO 2

\begin{tabular}{|lll}
$(\quad)$ banana & $($ ) manga \\
$(\quad)$ maçã & $($ ) uva \\
$(\quad)$ laranja & $($ ) abacate \\
$(\quad)$ tangerina & $($ ) melão \\
$(\quad)$ limão & $($ ) melancia \\
$(\quad)$ abacaxi & $($ ) mamão \\
$(\quad)$ kiwi & $($ ) maracujá \\
$(\quad)$ pera & $($ goiaba \\
$(\quad)$ morango & $($ pêssego \\
$(\quad)$ ameixa & $(\quad)$ nectarina \\
\hline
\end{tabular}


12. Que tipo de uso você costuma dar às frutas? Como você consome os produtos? (Assinalar todos os itens em ordem de importância) - USAR CARTÃO 3
( ) In natura
( ) Ingrediente de outros pratos
( ) Sucos
( ) Outros. Quais?

13. Eu vou mencionar algumas situações de consumo. Eu gostaria que você relacionasse as frutas que julga mais adequadas para cada situação - USAR CARTÕES 2 E 3

\section{In natura}

Ingrediente

Sucos

Outros

14. De maneira geral, você escolhe o tipo de fruta pensando no uso que elas terão? (ou primeiro compra e depois decide o que vai fazer com elas?)

( ) Não. Primeiro compra e depois decide o que vai fazer com as frutas

( ) Sim. Escolhe o tipo de fruta pensando no uso que elas terão 
15. Como você vê, em termos de confiabilidade, as seguintes fontes de informação (em relação a frutas) - USAR CARTÕES 4 E 5

\begin{tabular}{|c|c|c|c|c|c|}
\hline Fonte de informação & $\begin{array}{c}\text { muito } \\
\text { confiável }\end{array}$ & confiável & regular & $\begin{array}{c}\text { não } \\
\text { confiável }\end{array}$ & $\begin{array}{c}\text { Muito não } \\
\text { confiável }\end{array}$ \\
\hline \multicolumn{6}{|l|}{ médico da familia } \\
\hline \multicolumn{6}{|l|}{ clínicas de dietas, spas } \\
\hline \multicolumn{6}{|l|}{ nutricionista } \\
\hline \multicolumn{6}{|l|}{ artigos de revista } \\
\hline \multicolumn{6}{|l|}{ propagandas em revista } \\
\hline \multicolumn{6}{|l|}{ artigos de jornal } \\
\hline \multicolumn{6}{|l|}{ propagandas em jornal } \\
\hline \multicolumn{6}{|l|}{ comentários de rádio } \\
\hline \multicolumn{6}{|l|}{ propagandas no rádio } \\
\hline \multicolumn{6}{|l|}{ programas de TV } \\
\hline \multicolumn{6}{|l|}{ propagandas na TV } \\
\hline \multicolumn{6}{|l|}{ livros } \\
\hline \multicolumn{6}{|l|}{ amigos e família } \\
\hline \multicolumn{6}{|l|}{ escolas } \\
\hline \multicolumn{6}{|l|}{ governo } \\
\hline outros & & & & & \\
\hline
\end{tabular}


16. Como você vê, em termos de importância, os seguintes atributos de uma fruta USAR CARTÕES 6 E 7

\begin{tabular}{|c|c|c|c|c|c|}
\hline ATRIBUTO & $\begin{array}{c}\text { muito } \\
\text { importante }\end{array}$ & importante & regular & $\begin{array}{c}\text { pouco } \\
\text { importante }\end{array}$ & $\begin{array}{c}\text { não } \\
\text { importante }\end{array}$ \\
\hline \multicolumn{6}{|l|}{ nutrição } \\
\hline \multicolumn{6}{|l|}{ segurança } \\
\hline \multicolumn{6}{|l|}{ saudável } \\
\hline \multicolumn{6}{|l|}{ sabor } \\
\hline \multicolumn{6}{|l|}{ preço } \\
\hline \multicolumn{6}{|l|}{ frescor } \\
\hline \multicolumn{6}{|l|}{ aparência } \\
\hline \multicolumn{6}{|l|}{ marca } \\
\hline \multicolumn{6}{|l|}{ efeito ambiental } \\
\hline \multicolumn{6}{|l|}{$\begin{array}{l}\text { onde foi } \\
\text { produzido }\end{array}$} \\
\hline \multicolumn{6}{|l|}{ embalagem } \\
\hline \multicolumn{6}{|l|}{ selo de qualidade } \\
\hline \multicolumn{6}{|l|}{ firmeza } \\
\hline \multicolumn{6}{|l|}{ cor } \\
\hline \multicolumn{6}{|l|}{ variedade } \\
\hline \multicolumn{6}{|l|}{ tamanho } \\
\hline outros & & & & & \\
\hline
\end{tabular}

\section{II.) Compra}

1. Que tipo de informação você gostaria de ter sobre as frutas que consome?

\begin{tabular}{|c|}
\hline $\begin{array}{ll}( & \text { ) valor calórico } \\
( & \text { ) teor de gordura } \\
( & \text { ) vitaminas (teores) } \\
( & \text { ) composição }\end{array}$ \\
\hline
\end{tabular}


2. Que fatores você considera importantes em relação ao ambiente do ponto de venda? Qual é a ordem de importância? Citar pelo menos 3 fatores - USAR CARTÃo 8
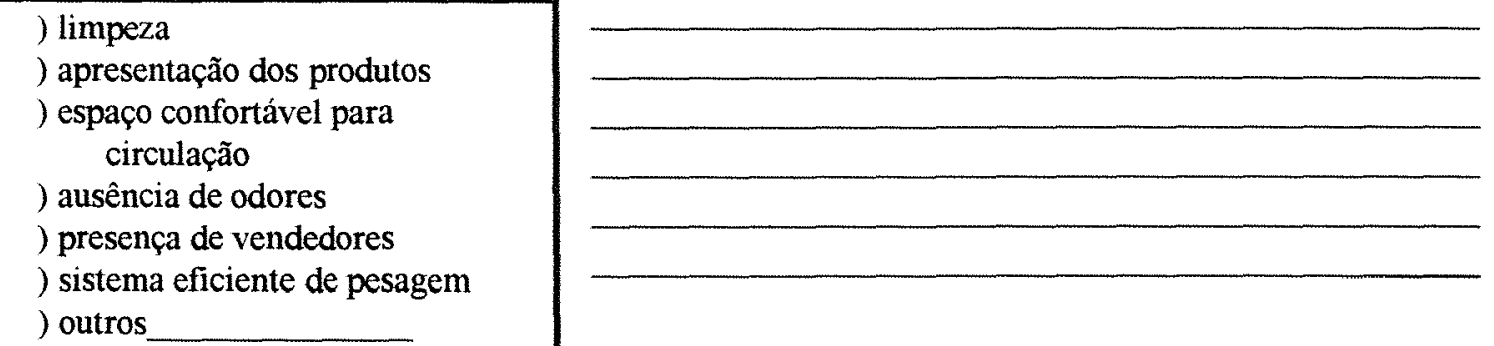

3. O tempo disponível para compra afeta a sua escolha de frutas?
( ) Não
( ) Sim. De que maneira?

4. Você adquire frutas da estação?

( ) Não

( ) Sim. Por que motivo(s)?

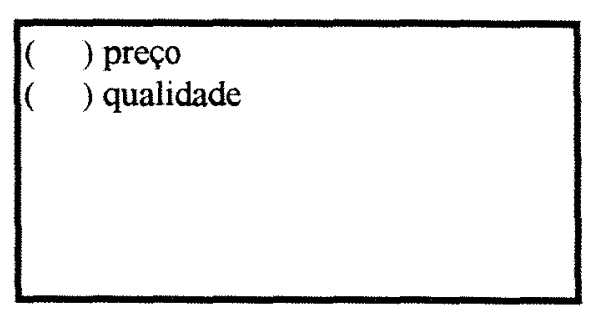

5. Onde você costuma comprar frutas? (Assinalar em ordem crescente de importância) USAR CARTÃO 9
( ) Lojas especializadas
( ) Feiras
( ) Supermercados
( ) Sacolões/Varejões
( ) Ambulantes
( ) Outros 
6. Por que você escolhe este local de compra?

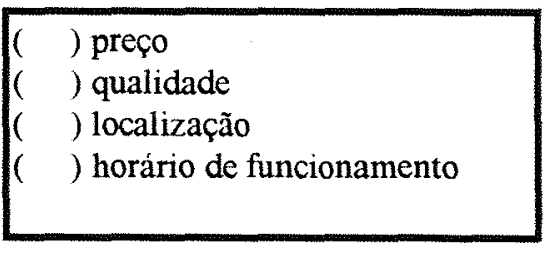

7. Quem decide sobre a compra de frutas, em sua residência?

8. Quem compra as frutas, em sua residência?

\section{III.) Pós-compra}

1. Como você costuma armazenar as frutas, em sua casa?

$(\quad)$ geladeira
$(\quad)$ fora da geladeira

2. Você mesmo(a) costuma preparar as frutas para o consumo? (doces, sucos etc..) USAR CARTÃO 10

\begin{tabular}{|c|c|c|c|c|}
\hline Nunca & Raramente & Medianamente & Freqüentemente & Sempre \\
\hline
\end{tabular}

3. A situação de consumo influi no tipo de frutas a ser escolhido?

$$
\text { ( ) Não }
$$


4. Que tipo de frutas você prefere consumir em relação a estas situações - USAR CARTÃO 2

Café da manhã

Lanche durante a manhã

Sobremesa do almoço

Lanche durante a tarde

Sobremesa do jantar

Lanche após o jantar

5. De maneira geral, quão satisfeito(a) você se encontra em relação às frutas que compra?

- USAR CARTÃO 11

( ) Nada
( ) Pouco
( ) Moderadamente
( ) Bastante
( ) Totalmente

Explique.

6. Qual é o grau de desperdício, em relação ao item frutas, em sua residência? - USAR CARTÃO 12

$$
\begin{aligned}
& \text { ( ) Nenhum } \\
& \text { ( ) Pouco } \\
& \text { ( ) Moderado } \\
& \text { ( ) Alto }
\end{aligned}
$$

Por que? 
7. O que você faz com os resíduos de frutas (cascas, sementes, etc.)?

( ) joga no lixo
( ) usa como adubo de plantas

\section{IV.) Dados gerais}

1. Quantas pessoas residem em sua casa?

Quais são suas idades e sexo?

\begin{tabular}{|c|c|c|c|}
\hline $\begin{array}{c}\text { SEXO (M OU } \\
\text { F) }\end{array}$ & IDADE & $\begin{array}{c}\text { PARTICIPAÇÃO } \\
\text { NO CONSUMO } \\
\text { DE FRUTAS (\%) }\end{array}$ \\
\hline & & \\
\hline & & \\
\hline & & \\
\hline & & \\
\hline & & \\
\hline & & & \\
\hline & & & \\
\hline & & & \\
\hline
\end{tabular}

2. Você poderia explicitar, de maneira geral, quem consome as frutas, em sua residência? Em que proporção?

(RESPOSTA NO QUADRO ANTERIOR)

3. Quantas pessoas trabalham fora de casa, em sua residência? 
4. Cor do entrevistado (só anotar, não perguntar):
( ) Branca
( ) Parda
( ) Preta
( ) Amarela

5. Qual é o seu grau de escolaridade? E do chefe da familia?

\section{ENTREVISTADO:}

Sabe ler e escrever:

$$
\text { ( ) Sim Não }
$$

Série:

Grau:

Total de anos de estudo: (a ser calculado)

\section{CHEFE DA FAMÍLA:}

Sabe ler e escrever:

$$
\text { ( ) Sim }
$$

Série:

Grau:

Total de anos de estudo:____ (a ser calculado)

6. Qual é a sua profissão/ ocupação? E do chefe da familia? 
7. Qual é a renda mensal familiar total? (Incluindo aposentadoria, pensões, aluguéis recebidos, rendimentos, etc..)

Salário:

Salário de outro membro da família:

Salário de outro membro da família:

Salário de outro membro da família:

Salário de outro membro da família:

Aposentadoria:

Aposentadoria de outro membro da família:

Aposentadoria de outro membro da família:

Pensões:

Aluguéis:

Rendimentos:

Outros (especificar):

TOTAL:

8. De maneira geral, qual o valor dedicado à compra de frutas, por semana?

9. Endereço:

Telefone:

\section{V.) Comentários}

Você gostaria de fazer algum outro comentário a respeito do consumo de frutas? 


\section{APÊNDICE 2}

Recursos visuais (cartões) utilizados nas entrevistas 
Cartão 1:

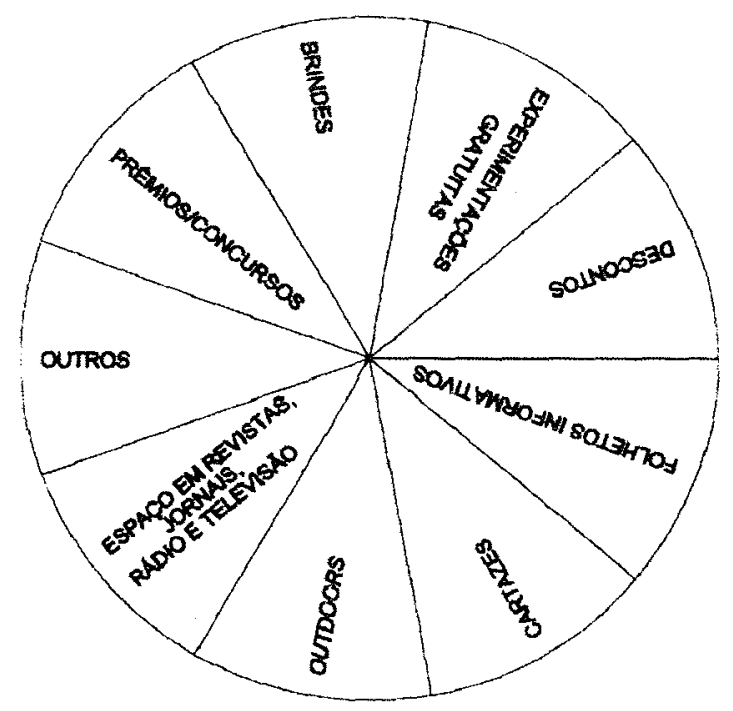

Cartão 2:

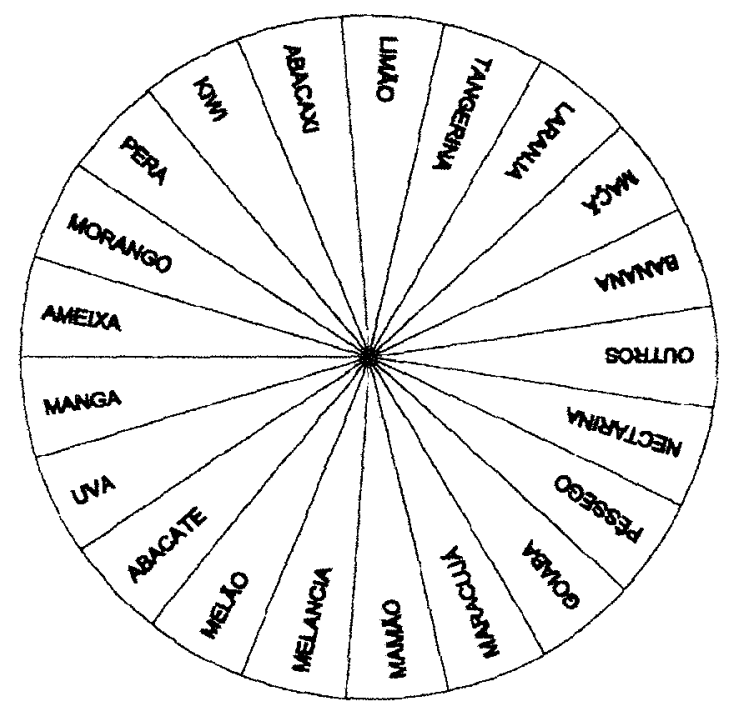

Cartão 3:

\begin{tabular}{|c|}
\hline INNATURA \\
\hline $\begin{array}{c}\text { INGREDIENTE DE OUTROS } \\
\text { PRATOS }\end{array}$ \\
\hline SUCOS \\
\hline OUTROS \\
\hline
\end{tabular}




\section{Cartão 4}

\begin{tabular}{|c|}
\hline MUIYO CONFIÁVL \\
\hline CONFLAVEL \\
\hline REGULAR \\
\hline NÃO CONFIÁVL \\
\hline MUITO NÃO CONFLÁVEL \\
\hline
\end{tabular}

\section{Cartão 5:}

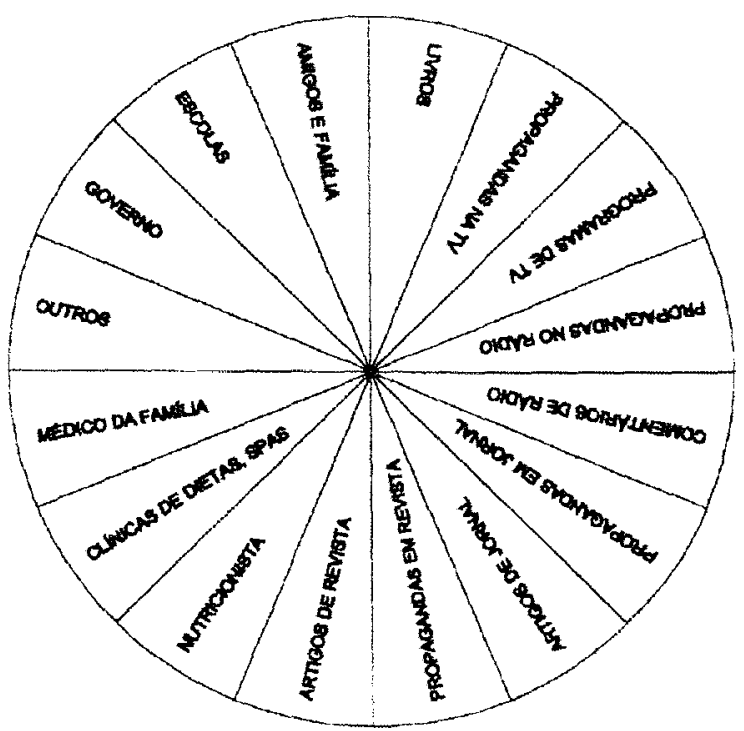

Cartão 6:

\begin{tabular}{|c|}
\hline MUITO IMPORTANTE \\
\hline IMPORTANTE \\
\hline REGULAR \\
\hline POUCO IMPORTANTE \\
\hline NÃO IMPORTANTE \\
\hline
\end{tabular}




\section{Cartão 7:}

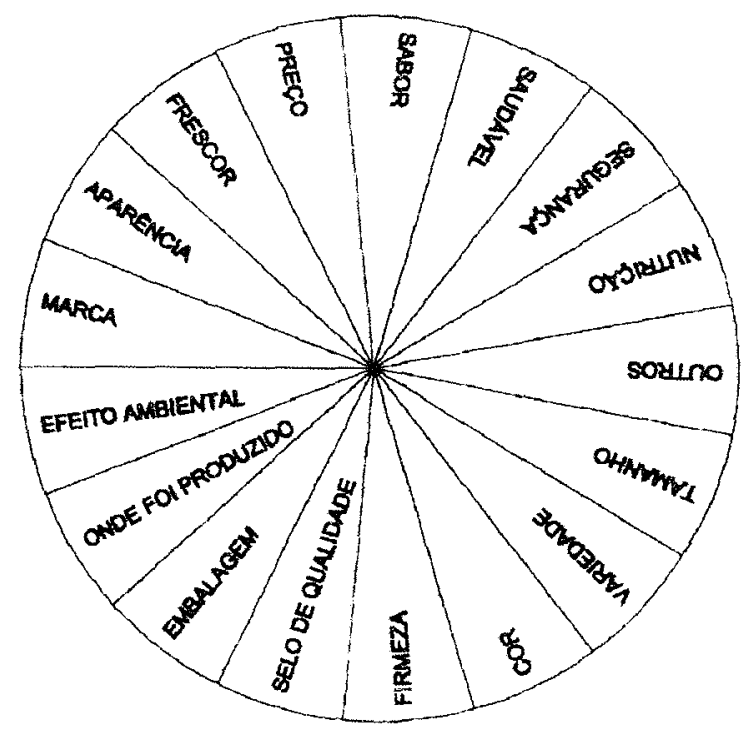

\section{Cartão 8:}

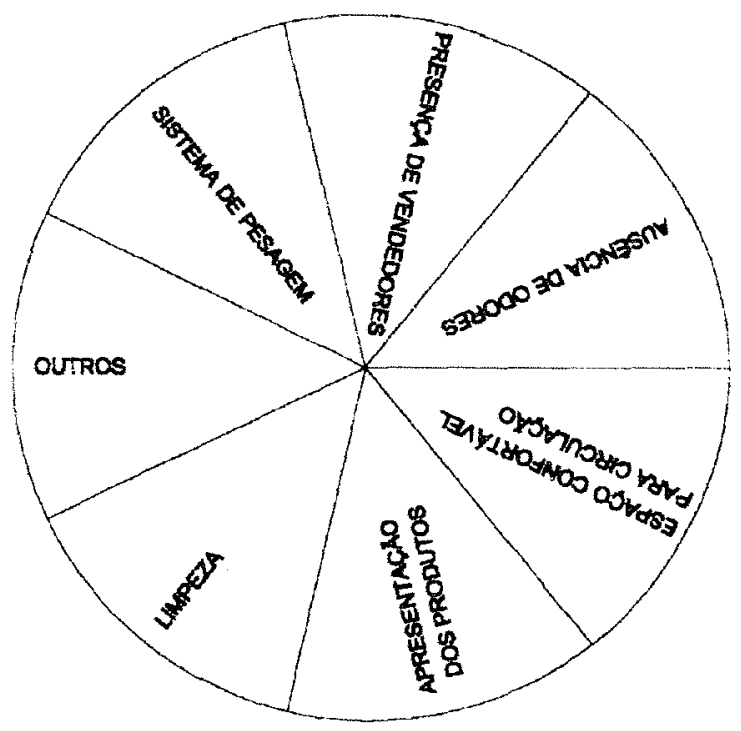




\section{Cartão 9:}

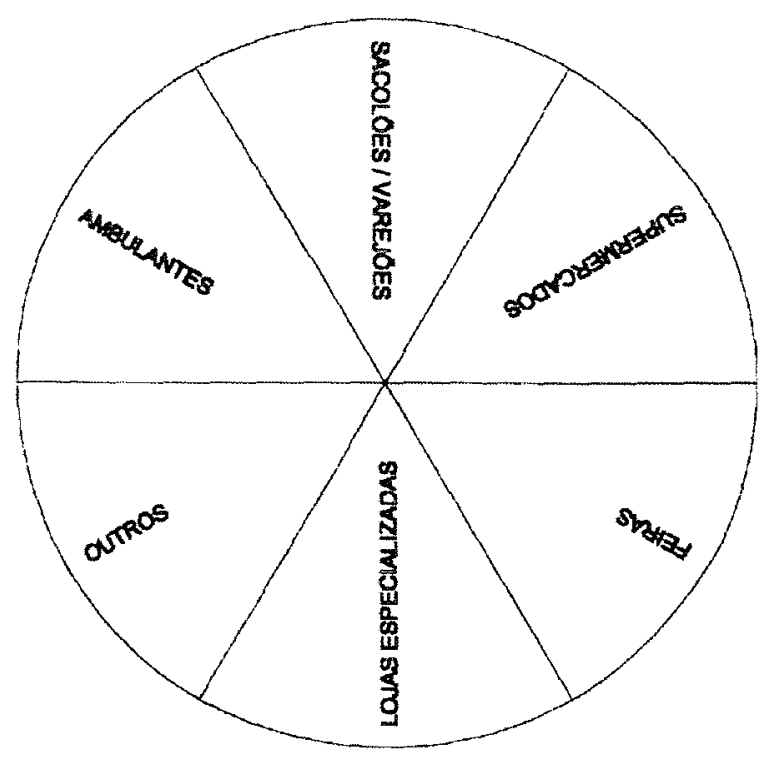

Cartão 10:

\begin{tabular}{|c|}
\hline NUNCA \\
\hline RARAMENTE \\
\hline MEDLANAMENTE \\
\hline FREQÜENTEMENTE \\
\hline SEMPRE \\
\hline
\end{tabular}

\section{Cartão 11:}

\begin{tabular}{|c|}
\hline NADA \\
\hline POICO \\
\hline MODERADAMENTE \\
\hline BASTAYTE \\
\hline TOTALMENTE \\
\hline
\end{tabular}


Cartão 12 :

\begin{tabular}{|c|}
\hline NENHUM \\
\hline POUCO \\
\hline MODERADO \\
\hline ALTO \\
\hline
\end{tabular}

